Daniel Camparo Avila

\title{
A musicalidade comunicativa das canções: \\ um estudo sobre a identidade sonora de crianças com autismo
}

(Versão original)

Tese apresentada ao Instituto de Psicologia da Universidade de São Paulo para obtenção do título de Doutor em Psicologia.

Área de Concentração: Psicologia Escolar e do Desenvolvimento Humano.

Orientadora: Prof ${ }^{a}$ Livre-Docente Maria Cristina M. Kupfer

São Paulo 
AUTORIZO A REPRODUÇÃO E DIVULGAÇÃO TOTAL OU PARCIAL DESTE TRABALHO, POR QUALQUER MEIO CONVENCIONAL OU ELETRÔNICO, PARA FINS DE ESTUDO E PESQUISA, DESDE QUE CITADA A FONTE.

Catalogação na publicação

Biblioteca Dante Moreira Leite

Instituto de Psicologia da Universidade de São Paulo

Avila, Daniel Camparo.

A musicalidade comunicativa das canções: um estudo sobre a identidade sonora de crianças com autismo / Daniel Camparo Avila; orientadora Maria Cristina Machado Kupfer. -- São Paulo, 2016.

$248 \mathrm{f}$.

Tese (Doutorado - Programa de Pós-Graduação em Psicologia. Área de Concentração: Psicologia da Aprendizagem, do Desenvolvimento e da Personalidade) - Instituto de Psicologia da Universidade de São Paulo.

1. Autismo 2. Música 3. Identidade I. Título. 
AVILA, D. C. A musicalidade comunicativa da canções: um estudo sobre a identidade sonora de crianças com autismo. Tese apresentada ao Instituto de Psicologia da Universidade de São Paulo para obtenção do título de Doutor em Psicologia Escolar e do Desenvolvimento Humano

Aprovado em:

Banca Examinadora

Prof. Dr.

Instituição:

Assinatura:

Prof. Dr.

Instituição:

Assinatura:

Prof. Dr.

Instituição:

Assinatura:

Prof. Dr.

Instituição:

Assinatura:

Prof. Dr.

Instituição:

Assinatura: 
A quem possa interessar. 


\section{AGRADECIMENTOS}

À Florencia, pelas incansáveis discussões e revisões dos manuscritos, pela potência da sua companhia, por todo o amor e ternura, por não deixar que me afogasse no impossível.

A toda a família, pelos diversos apoios para realizar esse projeto.

Às crianças que participaram da pesquisa, por tudo que me ensinaram, e aos seus pais, que permitiram a sua participação.

Ao Rômulo Alexis, pelas primorosas ilustrações.

Aos demais do JZSMTK, Rodrigo Gobbet, Matias Viola, Tiago Cavaloti, André Pereira e Francisco França, e d'Os Otávios, Régis Yasuoka, Guilherme Sarkis e Daniel Scandurra.

Ao Felipe Ribeiro, Guilherme Oliveira do Vale e Walter Victor, pelas ideias e amizade inestimáveis, pelos estudos cageanos e a tradução de Silence.

Aos mestres Roberto Michelino, Diego Arvate, Gabriel Kerhart, Diego Sampaio, Gregório Gananian, Tomás Troster, Oliver de Luccia e Rafael Murolo, pelas ideias de música.

À equipe do Núcleo de Educação Terapêutica, Paula Fonseca, Guilherme Oliveira, Thales Twardowsky, Júlia Franco e Juliana Arnhold.

À equipe do Lugar de Vida e todos aqueles que participaram da oficina.

Ao Tiago Lima, Julia Santos e Rogério Lerner, pelo salto qualitativo à pesquisa.

À Cristina Kupfer, pelo primeiro convite a participar da oficina de música, por compartilhar seu conhecimento clínico nas reuniões de orientação.

À Isabel Leme, pelo acompanhamento nos passos iniciais.

À Beatriz Coutinho Lerner, pelo convite para participar do Núcleo de Educação Terapêutica, pela colaboração na oficina e nas discussões clínicas, pelas contribuições na defesa.

À Rose Hikiji, pela introdução à Antropologia Musical, pela participação na banca.

À Teca de Brito, pelas aulas e pela generosidade em transmitir sua experiência na educação musical infantil, por participar na banca.

À Fátima Vicente, por ter gentilmente aceitado participar da defesa deste trabalho.

Esta pesquisa contou com o apoio financeiro da Coordenação de Aperfeiçoamento de Pessoal de Nível Superior (CAPES). 
Todo mundo tem uma canção, a qual não é canção alguma: é um processo de cantar, e quando vocês cantam, vocês sabem onde estão.

John Cage 


\section{RESUMO}

AVILA, D. C. A musicalidade comunicativa das canções: um estudo sobre a identidade sonora de crianças com autismo. 2016. 248 f. Tese (Doutorado) - Instituto de Psicologia, Universidade de São Paulo, São Paulo, 2016.

O manejo clínico das instâncias constitutivas da subjetividade por meio da música tem encontrado na identidade sonora um de seus eixos centrais. Ao mesmo tempo, diversas aplicações terapêuticas têm fundamentado sua justificativa na teoria da musicalidade comunicativa, que considera a capacidade de produzir e reconhecer as formas e qualidades expressivas no tempo que caracterizam e imprimem sentido aos sons como o fundamento das interações sociais, mesmo nas etapas iniciais do desenvolvimento. Apoiando-se na ideia de que crianças com autismo conservam tal capacidade, não obstante os problemas comportamentais, sociais e de linguagem, dispositivos que empregam a música com finalidades terapêuticas vêm apresentando resultados benéficos a essa população. Esta pesquisa pretendeu avaliar se a musicalidade da criança com autismo pode ser abordada com fins terapêuticos pelo uso de canções que se relacionem com sua identidade sonora e instaurem um campo possível para o surgimento de movimentos expressivos e de interação social. Para tanto, realizou-se uma oficina terapêutica com a participação de cinco crianças entre quatro e nove anos, durante um ano, com frequência semanal e duração de uma hora, em um total de 20 sessões. Os procedimentos empregados foram a improvisação musical, o jogo musical e recriação de canções. As sessões foram registradas com câmera de vídeo e segmentos foram selecionados e microanalisados, sendo posteriormente descritos em linguagem verbal, partituras musicais e gráficos de análise acústica, incorporados a estudos de caso individuais que utilizaram as categorias da Avaliação Psicanalítica aos 3 anos como indicadores clínicos. Simultaneamente, realizou-se um levantamento bibliográfico sobre livros, artigos de periódicos, teses e dissertações acadêmicas que incluíssem os temas pesquisados, resultando em uma revisão narrativa de estudos em um amplo escopo de disciplinas. A pesquisa indica que a música e as canções produzem efeitos terapêuticos em crianças com autismo, que os mesmos podem ser compreendidos em suas dimensões intrapsíquica, intersubjetiva e sociocultural. A oficina de música contribui também para o desenvolvimento da função psíquica da voz e a flexibilização do desenvolvimento de células musicais em motivos e figuras mais complexos. Também gera possibilidades de imitação, sincronização e coordenação de movimentos, facilitando a interação social entre seus participantes. Uma das dinâmicas que produziram engajamentos sociais mais intensos foi a construção em grupo de narrativas a partir de ideias musicais e temáticas trazidas pelas crianças. Além disso, a música teve um efeito mais eficiente que ordens, pedidos e reprimendas verbais na contenção dos movimentos agitados e agressivos de algumas crianças. Assim, a hipótese foi parcialmente comprovada, tendo em vista os diversos movimentos expressivos e de interação social evidenciados. Por outro lado, a noção teórica de que esses processos se orientam em torno do conceito de identidade não foi sustentada pela presente pesquisa, já que os movimentos de constituição subjetiva mais importantes verificados na parte empírica poderiam ser traduzidos como processos de identificação, e não de expressão de identidades.

Palavras-chave: Autismo. Música. Identidade. 


\begin{abstract}
AVILA, D. C. The communicative musicality of songs: a study on the sound identity of children with autism. 2016. 248p. Thesis (Ph.D. Degree) - Instituto de Psicologia, Universidade de São Paulo, São Paulo, 2016.

The clinical management of the constitutive instances of subjectivity through music has found in sound identity its central axis. At the same time, a number of therapeutic applications have based their justification upon the theory of communicative musicality, which considers the ability to produce and recognize the shapes and expressive qualities in time that characterize and provide sense to sounds as the foundation of social interactions, even in the early stages of development. Relying on the idea that children with autism retain this ability, despite the behavioral, social, and language problems, devices that use music for therapeutic purposes have shown beneficial outcomes for this population. This research aimed to evaluate whether the musicality of children with autism can be approached with therapeutic purposes by using songs that relate to their sound identity and introduce a possible field for the emergence of expressive movements and social interactions. To this end, a therapeutic atelier was organized with the participation of five children aged between four and nine years, during one year, with a weekly frequency and duration of an hour, for a total of 20 sessions. The procedures employed were musical improvisation, musical play and recreation of songs. The sessions were recorded with a video camera and segments were selected and microanalyzed, being later described in verbal language, musical scores and acoustic analysis graphics, embedded in individual case studies using the categories of the Psychoanalytic Evaluation After 3 years as clinical indicators. Simultaneously, a bibliographic survey of books, journal articles, theses and academic dissertations that include the investigated subjects was performed, resulting in a narrative review of studies on a broad range of disciplines. The research indicates that music and songs produce therapeutic effects in children with autism, which can be understood in their intra-psychic, inter-subjective and socio-cultural dimensions. The music atelier also contributes to the development of the psychic function of the voice and the flexibility of the development of musical cells into motifs and more complex figures. It also generates possibilities for imitation, synchronization and coordination of movements, facilitating social interaction among its participants. One of the dynamics that produced more intense social engagements was the group construction of narratives from musical and thematic ideas brought by the children. In addition, music had a more efficient effect than orders, requests and verbal reprimands in containing the agitated and aggressive movements of some children. Thus, the hypothesis was partially proven, in view of the many expressive movements and social interactions. On the other hand, the theoretical notion that these processes are oriented by the concept of identity was not supported by this research, since the most important movements of subjective constitution evidenced in the empirical part might be translated as identification processes, not of identity expression.
\end{abstract}

Keywords: Autism. Music. Identity. 


\section{LISTA DE FIGURAS}

Figura 1 - Fotografias dos instrumentos construídos para a oficina $\ldots \ldots \ldots \ldots \ldots \ldots \ldots \ldots$ p. 13

Figura 2 - Transcrição da canção de abertura e encerramento da oficina de música...... p. 14

Figura 3 - Ilustrações da disposição do grupo em roda na oficina de música............. p. 16

Figura 4 - Encarte do disco distribuído aos participantes.......................... p. 17

Figura 5 - Célula rítmica do jogo musical de apresentação dos nomes na oficina de

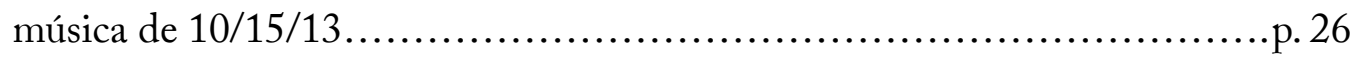

Figura 6 - Transcrição de trecho da recriação da canção "Banho é bom" na oficina de

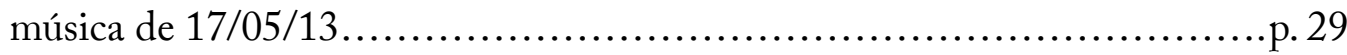

Figura 7 - Transcrição de trecho da recriação da canção "Atirei o pau no gato" na oficina de música de $24 / 05 / 13 \ldots \ldots \ldots \ldots \ldots \ldots \ldots \ldots \ldots \ldots \ldots \ldots \ldots \ldots \ldots . \ldots \ldots . \ldots \ldots$

Figura 8 - Transcrição da recriação da canção “Thomas e seus amigos” na oficina de

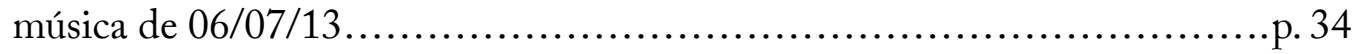

Figura 9 - Transcrição do final da canção de abertura do desenho "Thomas e seus amigos"....................................................... 34

Figura 10 - Transcrição da recriação da canção “Thomas e seus amigos” na oficina

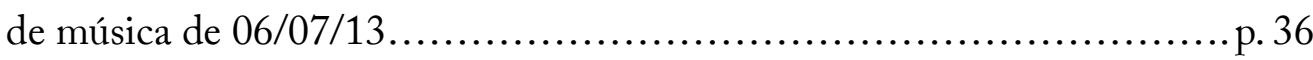

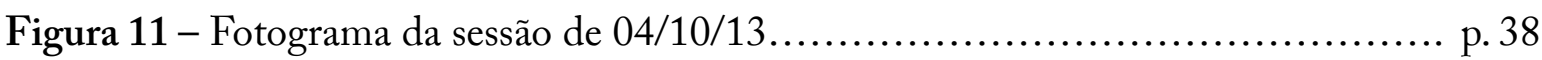

Figura 12 - Transcrição da improvisação "Música Assustadora” na oficina de música

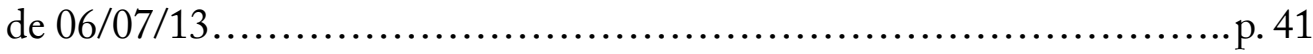

Figura 13 - Análise espectral e de pitch de uma vocalização de William na oficina

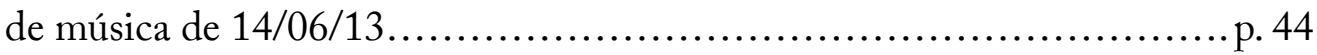

Figura 14 - Análise espectral, de intensidade e de pitch de trecho da canção

"Cocoricó na oficina de música de 21/06/13 .......................... p. 48

Figura 15 - Ilustração de coreografia da canção "A dona aranha" na oficina de música

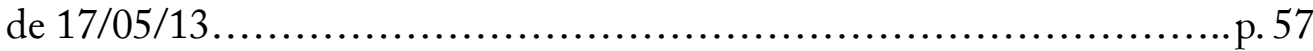

Figura 16 - Transcrição de segmento de improvisação na oficina de música de $06 / 07 / 13$ .p. 60

Figura 17 - Ilustrações da recriação da parlenda "Bruxa no castelo mal assombrado" na oficina de música de 07/06/13 
Figura 18 - Ilustrações da apresentação do motivo musical do filme “Tubarão”, na

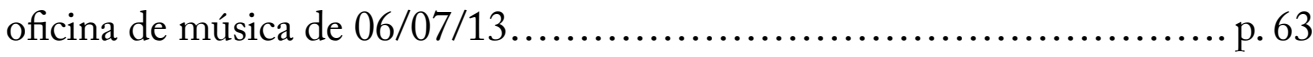

Figura 19 - Ilustrações do movimento de Pablo e William na oficina de música de

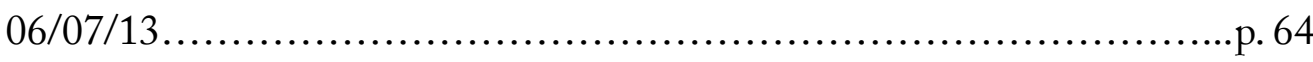

Figura 20 - Ilustrações da recriação da canção “Os indiozinhos” na oficina de música

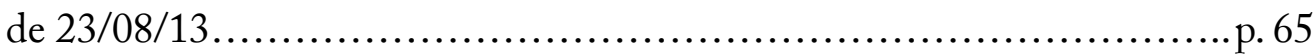

Figura 21 - Ilustração da recriação da canção de abertura da oficina de música de $29 / 11 / 13$ .p. 77

Figura 22 - Transcrição de recriação da canção de abertura da oficina de música de $29 / 11 / 13$ p. 79

Figura 23 - Ilustração de coreografia da canção "Banho é bom” na oficina de música

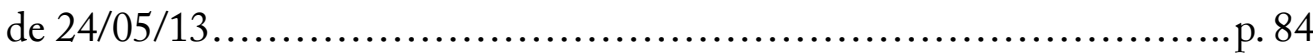

Figura 24 - Ilustrações de coreografia na oficina de música de 24/05/13 ................p. 85

Figura 25 - Ilustração de coreografia de ciranda na oficina de música de 24/05/13 ......p. 86

Figura 26 - Ilustrações de coreografia sobre tema do filme "Tubarão" na oficina de

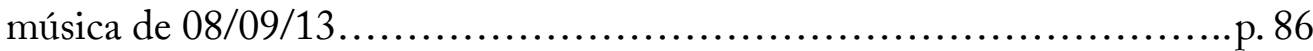

Figura 27 - Ilustrações da coreografia da canção "Cocoricó" na oficina de música de $29 / 11 / 13$ p. 91

Figura 28 - Análise espectral e de pitch de vocalização de Mathias na oficina de música de 24/05/13. p. 92

Figura 29 - Carta escrita por Mathias no atendimento individual.................... p. 94 


\section{SUMÁRIO}

1. INTRODUÇÃO 1

1.1. Apresentação 1

1.2. Música e psicanálise 1

1.3. Música, corpo e movimento 4

1.4. A nota azul 5

1.5. A musicalidade comunicativa das canções 6

2. METODOLOGIA 10

2.1. Revisão da literatura 10

2.2. Desenho de pesquisa 10

2.3. Participantes 11

2.4. Procedimentos 12

2.5. Registro e análise de filmes 17

2.5.1. Microanálise 18

2.5.2. Transcrições 20

2.5.3. Ilustrações 22

2.5.4. Análise acústica e espectral 22

3. ESTUDOS DE CASO 24

3.1. William 25

3.2. Pablo 54

3.3. Camila 70

3.4. Mathias 80

4. DISCUSSÃO 96

4.1. Autismo 96

4.2. Palavra cantada 108

4.3. Música 126

4.4. Narrativa 142

4.5. Ritmo 153

4.6. Corpo 162

4.7. Imitação 168

4.8. Identidade 172

5. CONCLUSÃO 186

REFERENCIAS 211

ANEXO A - TERMO DE CONSENTIMENTO LIVRE 231

E ESCLARECIDO

ANEXO B - TABELA DE CANÇÕES 233

ANEXO C - GLOSSÁRIO DE TERMOS MUSICAIS 234

ANEXO D - FAIXAS DO CD 236 


\section{INTRODUÇÃO}

\subsection{Apresentação}

Esta pesquisa tem como objetivo estudar o emprego da música como recurso terapêutico no tratamento de crianças com autismo. Mais especificamente, procura investigar os efeitos que canções podem produzir em um dispositivo clínico dedicado a essas crianças, chamado oficina de música. É um trabalho que pode ser lido por músicos e pessoas interessadas no tema do autismo, mas que, por vincular-se às ações de psicólogos, educadores e terapeutas que lidam com essa população, pode ser útil a esses profissionais, mesmo que contem com pouca ou nenhuma instrução musical. Espera-se que, além de poder contribuir às práticas que dedicamos a esses sujeitos com o objetivo de proporcionar-lhes uma melhor qualidade de vida, ele nos leve a questionar os discursos e os conhecimentos que acreditamos contar para compreendê-los e decidir o que pode ser melhor para eles. Contudo, antes de apresentarmos o estado atual da pesquisa, sua metodologia e resultados, repassaremos a trajetória que a conduziu até aqui.

\subsection{Música e psicanálise}

Meu interesse pela música provavelmente se manifestou em minha primeira infância, quando ainda a chamava de "mu-ca-si". Em uma das fotografias mais antigas que tenho de mim, estou em uma cadeirinha de bebê, no jardim da casa de meus avós, sorrindo, com um fone em meus ouvidos. Quando cumpri dez anos, iniciei os estudos de piano, primeiro em escolas e conservatórios, depois na antiga Escola Municipal de Música de São Paulo. Com a adolescência, minhas ideias de música começaram a tomar novas formas, e somei ao piano a guitarra elétrica. Ao mesmo tempo, me atraía cada vez mais a música contemporânea, e a possibilidade de experimentar novos sons me levou a outros instrumentos, o violino, o clarinete, o saxofone. Desde então, venho explorando diferentes processos produtivos orientados à ampliação dos limites da musicalidade, por meio do uso de técnicas estendidas, construção de instru- 
mentos e livre improvisação. A descoberta das obras de John Cage e Walter Smetak, em meados dos anos 2000, foram cruciais para todos os caminhos que percorri depois, porque me convenceram que a música, mais que uma forma de arte, é uma forma de vida.

Nessa mesma época, na graduação no Instituto de Psicologia, um dos primeiros movimentos concretos desta pesquisa foi a iniciação científica "Psicanálise e Música" (AVILA, 2006, 2007), orientada pela Profa Helena Maria Sampaio Bicalho. Tratava-se de um tema que vinha recebendo uma atenção crescente (p. ex. LECOURT, 1992; DIDIER-WEILL, 1997a, 1997b, KAUFFMAN, 1998), mas cujas iniciativas semelhantes, reconhecendo a inexistência de uma articulação sólida entre os dois campos, apontavam claramente para a dificuldade em estabelecer um diálogo interdisciplinar. Logo de partida, essas iniciativas padecem um revés: uma considerável ausência de referências à música na obra de Freud frente às suas diversas preocupações estéticas, mais frequentemente relacionadas às artes plásticas ou à literatura. E apesar de algumas figuras no campo psicanalítico terem se interessado pelo tema, o rechaço freudiano poderia ser considerado como paradigmático de um silêncio disseminado no movimento fundado por ele. Para Reik (1953), a explicação seria a resistência do material musical ao método interpretativo, dificuldade assumida por Freud (1914/1996a), e sobre a qual caía a responsabilidade da sua aversão frente a um fenômeno que a racionalidade é incapaz de dominar completamente. Como apreciar algo do qual não se pode ter certeza o que significa ou comunica? A psicanálise se enfrenta com um problema com o qual já se debatem diversas disciplinas como a filosofia, a psicologia da música e a musicologia, a saber, a determinação do sen tido musical. E os métodos de decifração que buscavam nela encontrar um sentido latente se mostraram ineficazes diante da multiplicidade de suas possibilidades semânticas, permanecendo aquém das expectativas. Desde então, como um obstáculo epistemológico (BACHELARD, 2001), a música se manteve, para empregar uma expressão de Pontalis (2005), fora das bordas ou confins da psicanálise. Os estudos analíticos sobre a música permaneceram longamente reduzidos a uma insistência do método interpretativo sobre o material musical e a um recorte limitado de objetos: a análise da escuta e do investimento libidinal ligado a ela, a biografia dos compositores e personagens, e a análise hermenêutica das composições, em especial dos libretos de ópera (SAFATLE, 2006).

Porém, se eram essas as considerações musicais que orientavam os primeiros escritos psicanalíticos, elas se multiplicariam exponencialmente na literatura recente, sobretudo após a inclusão da voz entre os objetos pulsionais por Lacan (1998). A música, considerada uma deriva- 
da da matéria vocal, ganhava então um lugar relevante na metapsicologia e uma presença relevante nos processos de constituição subjetiva, sem a necessidade de um tratamento linguístico semântico. Mais do que isso, ela passava a ser pensada como elemento da relação mais primordial do sujeito com a alteridade (DIDIER-WEILL, 1997b), na medida em que remeteria a um momento no desenvolvimento em que o sentido ainda não seria determinado pela palavra, e no qual as associações contam apenas com a musicalidade da voz para se constituírem.

Simultaneamente à realização dessa pesquisa teórica, uma oficina de música já era realizada semanalmente na Pré-Escola Terapêutica Lugar de Vida, instituição cujo trabalho estava baseado no "tratamento e no acompanhamento escolar de crianças e adolescentes com problemas psíquicos” (LUGAR DE VIDA, 2015) e que oferecia serviços comunitários de extensão pela Universidade de São Paulo. O público atendido era geralmente encaminhado com diagnósticos de distúrbio global do desenvolvimento e autismo, definidos por prejuízos graves nas habilidades de interação social e comunicação, ou pela presença de comportamentos, interesses e atividades estereotipados, identificados ainda nos três primeiros anos de vida (ASSOCIAÇÃO AMERICANA DE PSIQUIATRIA, 2002).

As duas estagiárias que coordenavam a oficina, Sandra Zanneti e Raquel Berg, tinham uma proposta de brincadeiras com canções, danças e instrumentos, com o objetivo de proporcionar um envolvimento com o outro marcado pela diversão e pelo entretenimento. A aposta da música como um dos representantes da cultura sustentava uma prática na qual as crianças pareciam encontrar um lugar junto aos demais, de uma maneira mais confortável e menos ameaçadora (ZANETTI; BERG, 2005).

Foi em uma visita em busca de material bibliográfico que fui convidado pela Prof ${ }^{a}$ Maria Cristina Kupfer a participar da oficina de música. O dispositivo funcionava semanalmente pela manhã em um sistema denominado "Portas Abertas", com uma outra oficina de jogos e brincadeiras ocorrendo simultaneamente, seguida de uma oficina de culinária onde as crianças preparavam um café da manhã. Elas tinham a liberdade de escolher de qual atividade participariam, e podiam inclusive encontrar um espaço para estarem sozinhas se assim precisassem, ainda que as intervenções fossem pensadas de modo a incidir na circulação social dessas crianças e, consequentemente, em seu tratamento (KUPFER, 2008).

Nos quatro anos seguintes em que coordenei a oficina de música do Lugar de Vida, dei sequência à proposta original e mantive algumas diretrizes, como a noção da música como um representante da cultura, a comemoração de festas populares, os jogos musicais e a confecção 
de instrumentos. Outras intervenções musicais também foram sendo progressivamente integradas, sobretudo a improvisação livre e o acompanhamento musical de atividades, como brincadeiras, pinturas, danças e até mesmo o lanche. A improvisação mostrou ser um modo possível de estabelecer contato com crianças que geralmente permaneciam isoladas, e uma comunicação não-verbal com outras que dificilmente faziam uso da palavra.

\subsection{Música, corpo e movimento}

A partir de 2008, a oficina de música sofreu algumas modificações, dado que as sessões haviam indicado a necessidade de uma maior atenção aos aspectos corporais, tanto em danças e coreografias, quanto nos jogos e improvisações musicais. Com um músico e uma dançarina convidados, Tiago Lima e Júlia Santos, e sob a orientação do Prof. Rogério Lerner, compusemos então uma nova oficina de "Música e Movimento", com novas hipóteses sobre o seu potencial clínico: que a música e a dança atuariam como um contorno a um corpo cujas bordas e imagem não foram plenamente constituídas; que a participação nas atividades envolveria uma satisfação pulsional vinculada não só a um outro, mas a um objeto da cultura; que a música e a dança seriam capazes de incidir na produção de cadeias associativas, dando novos sentidos a ações e palavras; e que a oficina seria um espaço de criação de novas possibilidades de expres são subjetiva que não fossem a desorganização psíquica e a formação de defesas. Ao mesmo tempo, uma metodologia de descrição e análise que permitisse uma melhor compreensão dos resultados que acompanhávamos cotidianamente foi estabelecida. Os eixos da Avaliação Psicanalítica aos 3 Anos (KUPFER et al., 2008) foram empregados na análise dos sintomas apresentados por essas crianças na leitura dos processos subjetivos abordados por nossas propostas e intervenções. Essa sistematização conferiu à pesquisa um maior grau de formalização e resultou em uma segunda iniciação científica pelo grupo de pesquisadores (LIMA et al., 2008).

Esse novo formato do dispositivo abriu um campo de expectativas e práticas enriquecedoras ao trabalho clínico. Tanto a música quanto a dança se mostraram eficazes nas intervenções destinadas aos movimentos estereotipados, transformando-os em gestos plenos de sentido. Em uma sessão, uma criança brincava com uma mesa, apoiando-a e batendo-a repetidamente contra uma parede. Em seguida, passamos a bater instrumentos de percussão na mesa e 
depois no chão, convite imediatamente aceito por ela, que deixou a mesa e passou a bater os pratos que lhe eram oferecidos. Em outra situação, essa mesma criança dobra e desdobra repetidamente as articulações de uma mesa, e a improvisação de uma canção sobre o que ela estava fazendo é acompanhada de uma perda gradual da intensidade dessa desmontagem. Mais tranquila, ela deixa a mesa e sai da sala. No entanto, quando tentamos repetir a intervenção, a fala mostrou não ser adequada ou suficiente. A ideia de que a palavra produzia mais efeitos quando enquadrada musicalmente era realmente instigante, e esse e outros aspectos desse dispositivo foram estudados mais extensamente por Lima (2012).

\subsection{A nota azul}

É dessa época que surgem as primeiras indicações de que as canções poderiam apresentar um potencial por descobrir. Tudo começou com um insight na prática clínica. Em uma sessão da oficina de música no Lugar de Vida, estávamos dois adultos e V., uma criança que rece bia atendimento. $\mathrm{O}$ outro adulto, Tiago, tocava no violão uma sequência harmônica em Sol menor, e eu o acompanhava improvisando com a gaita. V., sentado na cadeira entre nós dois, parecia estar gostando daquela levada, sorria e balançava a cabeça de um lado para o outro, o que nós dois também fazíamos. A improvisação já levava alguns minutos, e os três estávamos compartilhando um ritmo e uma animação crescentes, realmente nos divertindo com tudo aquilo. Havia uma conexão e afinação que era o auge de um trabalho clínico e musical que levava meses até aí, e que vinha mostrando resultados na relação entre nós, e de V. com as outras pessoas. Em algum momento, deixei de tocar a gaita, e Tiago seguiu com a base no violão. Começo então a cantar os versos de uma canção dos Beatles: You say you want a revolution. Well, you know, we all want to change the world..., que se encaixa naquele andamento e tonalidade. A voz faz o acompanhamento instrumental passar a um registro de intensidade mais baixa, mas a reação de V. é completamente oposta. Assim que começo a cantar, ele me olha arregalando os olhos e salta da cadeira. Seu corpo é pesado, mas ele sai correndo e dá duas voltas no salão de 8x6 metros, gritando e cantando. Eu e Tiago nos olhamos e continuamos a tocar e cantar, e logo V. para adiante de nós e nos abraça. Depois volta a correr pela sala, e nos abraça novamente. 
Aquele evento me provocou uma incerteza que motivou a realização da pesquisa atual. $\mathrm{O}$ certo era que aquela expressão ativa de alegria e energia era algo raro para V., contrastando com a sua atitude habitualmente passiva, com o corpo hipotonificado e lânguido. As cadeiras do salão, como aquela em que ele estava sentado, eram o seu lugar favorito nas sessões, escolhendo sempre a mais confortável e sentando-se nela tão logo chegasse, levantando-se apenas com a nossa insistência. A improvisação era capaz de fazê-lo dançar e compartilhar um bom momento conosco, mas a canção havia provocado algo completamente diferente. Ela o havia literalmente tirado de sua posição e feito ele agir de uma maneira que eu nunca havia visto antes, uma alegria que ele demonstrava sentir nos músculos. A música havia tocado algo naquele menino.

Aquela situação apontava para a ação emergente de algum mecanismo subjetivo. Mas qual fator poderia ter desencadeado essa reação? A sequência de improvisação e canto? A melodia da voz? A tonalidade ou aquela canção específica? Os Beatles? Naquele momento, o fato de a canção ter sido o evento associado a tal efeito encontrava apoio na noção teórica de nota azul, formulada por Didier-Weill (1997a). Segundo esse autor, as primeiras marcas no psiquismo deixadas pelos sons constituem uma espécie de assinatura sonora pessoal e inconsciente, que é posteriormente acionada nos encontros que o sujeito terá com a música. É isso o que justificaria a sensação, ao ouvir uma canção, por exemplo, de que algo que é cantado por outra pessoa diz respeito a uma experiência que é, na verdade, a de quem a ouve. Como argumenta Didier-Weill (1997b), a nota azul teria esse poder de apresentar ao sujeito algo que sempre esteve presente em seu psiquismo, mas que lhe era desconhecido. E a música assumiria, ao tornar esse conteúdo audível, uma potência inesperada de arrebatamento, um "poder de me despertar" (p. 250).

\subsection{A musicalidade comunicativa das canções}

A nota azul seria uma noção fundamental no prosseguimento da investigação, quando a pergunta sobre os efeitos terapêuticos da música se desdobraria em questionar "qual é o som de uma criança?", "por que é este o som de uma criança?" ou, antes disso, "como encontrar o som de uma criança?”. Uma posterior revisão da literatura sobre o tema indicou que estas pre- 
ocupações estavam presentes em um ramo da Musicoterapia que sustentava sua prática clínica sobre o conceito de identidade sonora. De acordo com Benenzon (1985), esta constitui "o mosaico dinâmico (...) que caracteriza o indivíduo” (p. 44), podendo ser usada para abrir um canal de comunicação. $\mathrm{O}$ musicoterapeuta alcançaria esse objetivo, por exemplo, imitando ou fazendo tudo aquilo que o paciente faz, isto é, balbuciar junto com os bebês, reproduzir os ruídos e ecolalias da criança autista, etc. A qualidade de abertura desse canal, contudo, dependeria da reprodução, ao longo da imitação, dos sons que distinguissem aquela pessoa de todas as demais, que a diferenciassem e caracterizassem, isto é, que se relacionassem com sua identidade sonora.

Apesar de essa hipótese ter sido formulada há um período razoável de tempo e ser de uso corrente entre terapeutas, a natureza e funcionamento da identidade sonora permanecem ainda sem serem completamente elucidados. Um possível caminho de investigação nesse sentido seria empregar o enfoque do desenvolvimento infantil e a noção de musicalidade comunicativa, nome dado por Trevarthen e Malloch (2009) à capacidade humana de conferir um sentido compartilhado a formas e qualidades de expressões no tempo e, desse modo, engajar-se na comunicação com um outro. Muito antes que se faça uso da palavra, já nas primeiras interações entre o bebê e seu cuidador, os comportamentos corporais e vocais são suficientes não apenas para estabelecer uma relação de interação recíproca, quanto para criar narrativas que estruturam uma transmissão complexa dos motivos e intenções de cada um. Isso indica que os seres humanos estão biologicamente preparados para se integrar à interação social desde o seu nascimento por meio de sons e movimentos, já que são eles que permitem as primeiras companhias coordenadas e experiências compartilhadas. E tal capacidade se estenderia por toda a vida dos indivíduos, mesmo quando a linguagem se torna um meio eficaz de comunicação, fazendo da musicalidade comunicativa o rudimento que torna possível não só a música mas a aprendizagem cultural, e provavelmente todo o mundo humano. Desde a entrada do sujeito em uma relação com um outro, e depois com sua comunidade, é ela quem nos introduziria em um lugar na história de um grupo que nos antecede, e forneceria as bases sobre as quais se assentam as estruturas que nos tornam o que somos.

A teoria da musicalidade comunicativa pode, nesse sentido, oferecer um complemento à noção de identidade sonora, já que os comportamentos comunicativos da primeira infância tanto revelariam o aspecto musical dos processos de socialização e interação, como também apresentariam elementos de constituição subjetiva identificáveis nos movimentos expressivos 
que, por sua vez, poderiam ser associados a narrativas da identidade pessoal. As canções, por serem uma forma musical que manifesta narrativas de vida e, portanto, da identidade (DREHER, 2005, 2006), ofereceriam uma articulação privilegiada entre a musicalidade comunicativa e a identidade sonora, o que poderia explicar a sua validade clínica no desenvolvimento de habilidades comunicativas, sociais e comportamentais.

Esse marco teórico deslindaria para a canção uma possível compreensão do funcionamento de práticas musicais terapêuticas no que se referem à identidade sonora, abrindo um questionamento sobre quais são os mecanismos incluídos e seus efeitos sobre as crianças envolvidas nessas práticas. Além disso, ele aventa a ideia de que, por meio do exercício da comunicação musical, crianças com autismo poderiam retomar de alguma forma seu desenvolvimento, diminuindo os efeitos produzidos pela síndrome. Inseridos nessa perspectiva construímos, para os fins desta investigação, a seguinte hipótese de pesquisa: a musicalidade da criança com autismo pode ser abordada com fins terapêuticos em uma intervenção baseada no uso de canções que se relacionem com sua identidade sonora e instaurem um campo possível para o surgimento de movimentos expressivos e de interação social. Para averiguá-la, uma oficina de música empregando canções como recurso terapêutico foi oferecida a um grupo de crianças, sendo as sessões registradas e analisadas, e os resultados discutidos à luz de um aprofundamento teórico sobre o tema.

Este trabalho se estrutura da seguinte maneira. Após esta introdução, a metodologia empregada é apresentada, detalhando os procedimentos do dispositivo e de revisão da literatura, o desenho de pesquisa proposto, a descrição dos participantes e as diretrizes éticas, bem como as formas de registro e análise. Além da descrição deste último aspecto, alguns dos resultados obtidos por outras pesquisas que empregaram procedimentos semelhantes são apresentados e comentados brevemente. A apresentação dos resultados e a análise dos dados é feita na forma de estudos de caso individuais no terceiro capítulo. Neles, descreve-se o percurso dos participantes desde a sua recepção, os eventos ocorridos ao longo das sessões de atendimento e as perspectivas prognósticas. As análises e reflexões clínicas sobre as intervenções planejadas e realizadas são acompanhadas de orientações de tratamento a partir dos procedimentos adotados.

No penúltimo capítulo, as conclusões obtidas são articuladas com a revisão de literatura, com o objetivo de averiguar a hipótese formulada. Para cumprir com esse objetivo, pretendeuse dar um panorama das questões mais importantes que surgiram da prática clínica e da pesquisa teórica, às quais esta pesquisa pode de alguma forma contribuir. Por fim, apresentamos as 
conclusões, incluindo um resumo dos principais resultados, a avaliação da metodologia e das limitações da pesquisa, bem como suas contribuições. O texto encerra com o Termo de Consentimento Livre e Esclarecido, uma tabela das canções usadas durante as sessões da oficina, um glossário dos termos musicais empregados e uma lista das faixas do CD que acompanha este volume. 


\section{METODOLOGIA}

\subsection{Revisão da literatura}

Ao longo de toda a pesquisa, foi realizado um levantamento bibliográfico sobre livros, artigos de periódicos, teses e dissertações acadêmicas que incluíssem os temas aqui pesquisados. As fontes foram extraídas de buscadores e indexadores de periódicos: ISI Web of Knowledge (isiknowledge.com), Portal da pesquisa (portaldapesquisa.com.br), BVS - Psicologia (bvs-psi.org.br), JSTOR (jstor.org), Biblioteca Científica Eletrônica em Linha (scielo.org), Portal Periódicos CAPES (periodicos.capes.gov.br), Cairn (cairn.info), Google Scholar (schola.google.com); catálogos de acervos de instituições de ensino superior: Dedalus-USP (dedalus.usp.br), Acervus-UNICAMP (acervus.bc.unicamp.br), Lumen - PUC-SP (biblio.pucsp.br/) Athena-UNESP (portal.biblioteca.unesp.br/portal/athena), C@thedra-UNESP (unesp.br/cgb); e bibliotecas digitais de teses e dissertações: UNICAMP (libdigi.unicamp.br) e USP (teses.usp.br).

Para abordar a complexidade do objeto de investigação, buscou-se realizar a seleção dos textos de modo a cumprir com uma revisão narrativa de estudos em um amplo escopo de disciplinas. Nesse sentido, foi priorizada a seleção de revisões sistemáticas, bem como a análise das referências dos demais trabalhos, de modo a traçar um panorama para cada campo de conhecimento. A seleção priorizou também, quando possível, os trabalhos mais recentes, com o objetivo de abordar as questões atuais de cada disciplina.

\subsection{Desenho de pesquisa}

Levando em consideração os objetivos da pesquisa, a estrutura necessária e o limite de tempo disponível, o desenho de pesquisa selecionado foi o estudo de caso a partir de uma abordagem intervencional. A modalidade que demonstrou ser mais adequada aos propósitos dessa pesquisa foi a do grupo terapêutico (ZENONI, 2002), por permitir a realização dos pro- 
cedimentos de investigação em um contexto que incrementa as díades possíveis de interação, além de possibilitar uma intervenção a curto prazo. Esse dispositivo conjuga o método analítico à prática institucional e está presente em diversas organizações de atenção a crianças com transtornos de desenvolvimento ao redor do mundo, tais como Antenne 110 e Courtil, na Bélgica; Bonneuil, na França; hospital-dia Tobar Garcia e Centro Lydia Coriat, na Argentina; Centro de Pesquisa em Psicanálise e Linguagem e Lugar de Vida, no Brasil. Pode-se considerar a oficina de música como parte da montagem institucional de um tipo de intervenção denominado Educação Terapêutica (KUPFER, 2000), baseado em um conjunto de práticas interdisciplinares de tratamento que vincula as esferas do tratar e do educar.

A oficina se realizou às sextas feiras, das 10 às 11 horas da manhã, entre 03/05 e 06/12/13, em um total de 20 sessões, com frequência semanal e duração de uma hora por sessão. Ela se inseriu no contexto do Núcleo de Educação Terapêutica do Instituto de Psicologia da Universidade de São Paulo, vinculada a um programa de tratamento de psicopatologias da infância que inclui também uma oficina de atividades variadas como brincadeiras, jogos, escrita, etc., chamado Grupo da Manhã, coordenado pela psicóloga Ana Beatriz Coutinho Lerner, e sessões de atendimento individual de uma hora por semana, oferecidas por um aluno da graduação em Psicologia do Instituto, em caráter de estágio, ou da psicóloga vinculada ao Núcleo, Paula Fontana Fonseca. Além dessas profissionais, os estagiários Guilherme, Thales, Júlia e Juliana também participaram das sessões da oficina de música e do grupo da manhã, compartilhando as atividades, acompanhando as crianças que por alguma razão não participavam do grupo e registrando em câmera de vídeo as sessões da oficina. Quando mais de uma criança faltava e havia um número excessivo de adultos, algum dos estagiários não participava, mantendo um número equilibrado de adultos e crianças. Após a oficina de música, toda a equipe se reunia por uma hora para a discussão dos atendimentos individuais e em grupo da semana, debatendo questões clínicas e de direção de tratamento, além de planejar estratégias coordenadas a serem empregadas nos dois níveis de atenção.

\subsection{Participantes}

O número de participantes da pesquisa foi de cinco crianças, entre 4 e 9 anos. Para pre- 
servar a sua identidade, seus nomes originais foram substituídos por William, Camila, Mathias, Pablo e Sofia Os estudos de caso corresponderão às quatro primeiras pois Sofia, apesar da indicação de participação em grupo terapêutico, não apresentava diagnóstico ou hipótese diagnóstica de autismo Dos demais participantes, dois haviam sido diagnosticados com distúrbios globais do desenvolvimento, um não havia recebido nenhum diagnóstico até o momento e do último não foi possível concluir se um diagnóstico havia sido feito até então.

Todos os sujeitos participantes da pesquisa tiveram um Termo de Consentimento Livre e Esclarecido (ANEXO A) preenchido pelos pais ou responsáveis em uma reunião na qual foram informados pelo pesquisador sobre os objetivos e procedimentos empregados, garantindolhes o sigilo e confidencialidade dos dados. O projeto e seus anexos foram submetidos à avaliação ética e metodológica da Comissão Nacional de Ética em Pesquisa, sendo registrados na Plataforma Brasil, em conformidade à resolução 196/96 do Conselho Nacional de Saúde.

\subsection{Procedimentos}

As sessões da oficina de música foram realizadas em duas salas do andar térreo do bloco D do Instituto de Psicologia da Universidade de São Paulo. No primeiro semestre, destinou-se às atividades uma sala de aproximadamente $3 \times 6$ metros no final de um corredor de quase 20 metros de comprimento. No lado oposto à porta de entrada da sala, encontram-se duas grandes janelas e uma porta de vidro, que conduz a um dos jardins internos do bloco. Por esta configuração, trata-se de um espaço iluminado e arejado, amplo o suficiente para permitir a circulação dos participantes, além de permitir o trânsito entre o jardim e o corredor anexos. Por se tratar de uma sala de atividades de ensino e reuniões de grupos de pesquisa, no interior da sala encontram-se cadeiras que são usadas nessas situações. Por ocasião dos atendimentos em grupo, retirávamos as cadeiras para o jardim, trazendo-as de volta ao final da sessão.

No segundo semestre, a oficina foi realizada em uma sala-ateliê, preparada para atendimentos em grupo que empregam linguagem artísticas. Trata-se de uma sala maior, com aproximadamente 10x8 metros, igualmente iluminada e arejada, com janelas amplas e uma porta para outro jardim interno. Conta com um armário onde eram guardados os instrumentos, uma 
pia e uma lousa móvel. Além disso, estavam disponíveis um conjunto de mesa e cadeiras, outro de tamanho infantil, e alguns colchonetes, sobre os quais nos sentávamos durante a oficina.

Segundo Bleger (2007), um grupo se define por "um conjunto de indivíduos que interagem entre si compartilhando certas normas numa tarefa" (p. 101). No nosso caso, as normas eram a participação nas atividades propostas e a permanência no espaço da oficina durante o tempo da sessão, o cuidado do lugar, dos materiais, dos outros e de si mesmo. Essas condições eram permanentemente recordadas e discutidas, ainda que as duas primeiras pudessem ser flexibilizadas em função das necessidades de cada participante. A tarefa proposta era a de "fazer música”, estimulando o uso de instrumentos musicais diversos, tais como tambores, xilofone de brinquedo, caxixis, flauta doce, flauta de pã e apitos variados. Em uma das sessões do grupo da manhã, o grupo construiu alguns instrumentos a partir de materiais recicláveis trazidos pelo pesquisador, como garrafas PET de diversos tamanhos, cabos de vassoura, grãos de feijão e arroz, etc. Esses instrumentos (Fig. 1) foram empregados nas sessões seguintes da oficina.
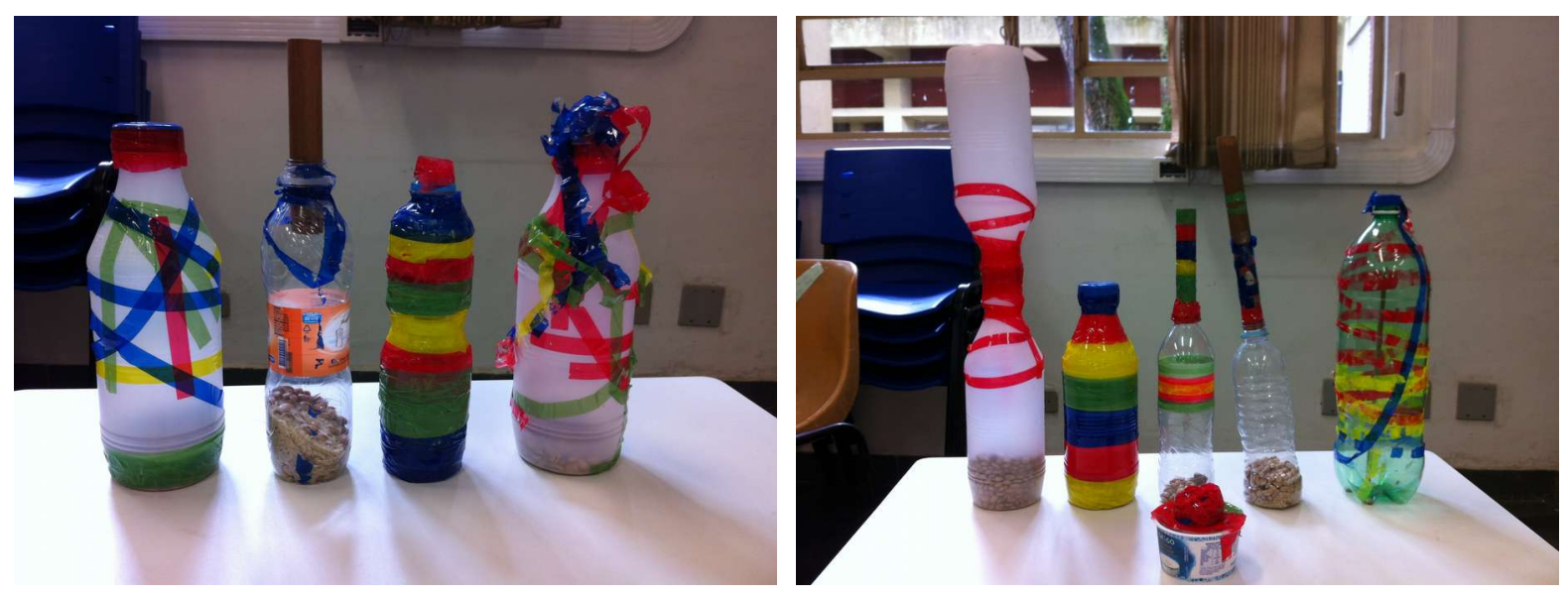

Figura 1 - Fotografias dos instrumentos construídos para a oficina

O pesquisador levava também um violão para a apresentação das canções e os demais procedimentos da oficina. A cada sessão, os instrumentos eram primeiramente selecionados em função do número de participantes presentes e a estratégia a ser empregada naquele dia. Nesse momento, a oficina se iniciava com as crianças e adultos sentando-se em roda e a escolha dos instrumentos, seguido da apresentação da canção de abertura "A oficina de música já vai começar” (Fig. 2), na qual cada um se apresentava junto com seu instrumento no momento em que era chamado pela canção. $O$ encerramento das sessões também obedecia ao mesmo procedimento durante a canção "A oficina de música já vai terminar", na qual, após apresentar os instrumentos, pedia-se às crianças que os guardassem. Após o fim da sessão, as crianças 
eram levadas pelos adultos aos pais, que as aguardavam na sala de espera. De um modo geral, essa foi a organização regular de todas as sessões.

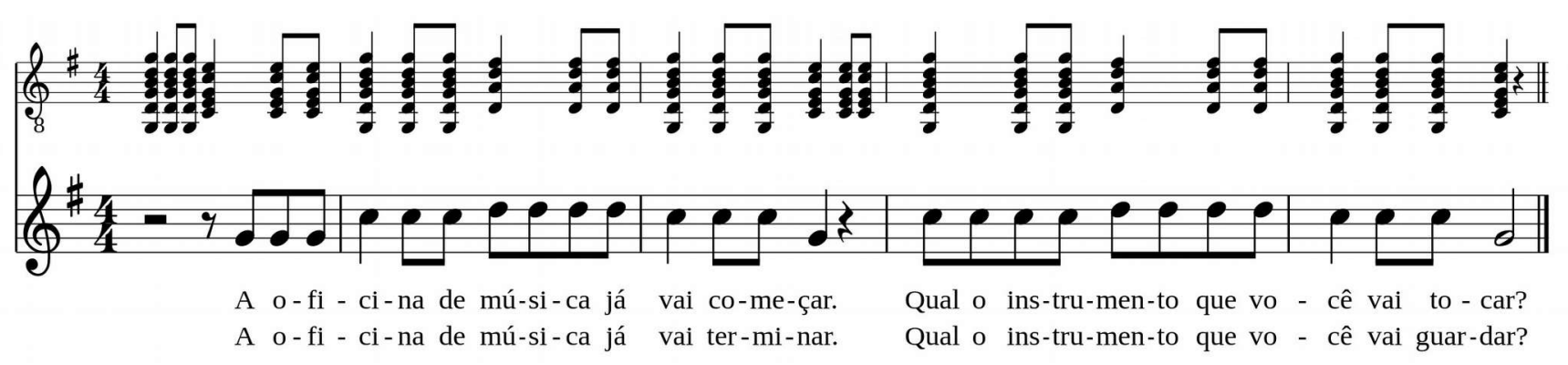

Figura 2 - Transcrição da canção de abertura e encerramento da oficina de música

Os procedimentos empregados durante as sessões clínicas foram a improvisação musical, o jogo musical e a recriação de canções. Essas técnicas foram selecionadas pela relevância apontada na literatura com relação à temática em questão, pela experiência pessoal do pesquisador e pelas relações que estabelecem e desenvolvem com a identidade sonora por meio da musicalidade comunicativa da criança. Elas são descritas abaixo, com uma justificativa em função dos objetivos esperados.

A improvisação musical (BRUSCIA, 2000; WIGRAM, 2004) corresponde a todo tipo de improvisação livre ou estruturada empregando múltiplos meios: voz, sons corporais, instrumentos ou qualquer combinação de recursos sonoros, podendo ser realizada em solo, dueto ou em grupo. Podem ser mobilizadas distintas instâncias de improvisação, recriação e audição musical visando o desenvolvimento de habilidades comunicativas e sua capacidade de interação social (GOLD; WIGRAM; ELEFANT, 2008). Ao constituir um modo de interação e compartilhamento, a improvisação incide sobre a musicalidade comunicativa, o que podemos depreender das suas possibilidades, como as reunidas por Chavarrias (2002): favorecer a comunicação possibilitando a troca de ideias ou sentimentos, tanto por quem escuta quanto por quem executa; melhorar as relações interpessoais, gerando um clima que permite a expressão e o relacionamento com o outro; desenvolver o conhecimento de si mesmo, obtendo assim experiências gratificantes consigo mesmo; e desenvolver a capacidade de autoexpressão, por meio do poder da interação improvisacional em evocar, associar e integrar.

O jogo musical (MARTINEZ, 2009) abarca as atividades lúdicas definidas em função da presença de padrões rítmicos e melódicos recorrentes e elaborados (de acordo à estrutura repetição-variação) ou de acordo à sujeição das condutas a um pulso musical subjacente. Um 
exemplo são as brincadeiras de roda, que estimulam a socialização e o contato com o outro pelo fato de dar as mãos e estabelecer movimentos coordenados. A hipótese é que canções com palavras simples, frases repetitivas e sílabas sem sentido, também repetitivas, podem contribuir para o exercício da musicalidade comunicativa dessas crianças. Outras atividades musicais lúdicas, como jogos rítmicos, podem também desenvolver a atenção e memória, a capacidade de expressão, a capacidade rítmica, a orientação espaço-temporal, a disciplina e a aquisição do esquema corporal.

A recriação é uma técnica musicoterapêutica que, segundo Bruscia (2000), inclui a execução, apresentação, transformação e interpretação de um modelo musical existente, como as canções. A forma canção está presente nas produções musicais cotidianas das crianças, seja nos ambientes que elas frequentam, seja em suas atividades lúdicas ou nos produtos culturais que consomem. Isso aproxima os procedimentos do seu dia a dia e, segundo Adorno (2009), permite que seus resultados sejam igualmente extrapolados para outros domínios da sua vida cotidiana. $\mathrm{Na}$ oficina de música, é possível recriar ao meno quatro tipos de canção. Em primeiro lugar, estão as canções infantis tradicionais, parte do folclore popular e da cultura. Em seguida, podemos recriar canções de um repertório infantil contemporâneo, sobretudo de desenhos animados e programas de televisão. Outro tipo é a canção improvisada, na qual letra, ritmo, melodia e harmonia podem ser improvisados, sendo que ao menos parte desses elementos pode ser incorporado de um modelo já existente. Por fim, a recriação de canções pessoais (DREHER, 2005) consiste em uma técnica músico-verbal na qual o terapeuta dedica ao cliente uma canção composta em razão de sua interação com a criança e dos conteúdos verbais e não-verbais que aparecem na interação entre eles. Compostas, apresentadas e reapresentadas, as canções podem estabelecer uma relação com a identidade sonora da criança, estimulando a musicalidade comunicativa a ela relacionada e possibilitando um canal de expressão que dê suporte aos conteúdos pessoais.

Em todas as sessões, houve situações de improvisação ocorrendo nos intervalos entre uma canção e outra ou entre as partes de algumas canções, nas quais o pesquisador mantinha a base harmônica e rítmica da canção e as crianças improvisavam em seus instrumentos. Os jogos musicais consistiram nas brincadeiras de roda, que ocorreram em algumas sessões nas quais todos nos levantamos e dançamos com as mãos dadas em um círculo, e nos jogos de alternância, tanto de intensidades - tocando a canção em volume alto e sua repetição em volume mais baixo - quanto de instrumentos - em que cada criança tocava seu instrumento em um 
momento específico de uma canção ou improvisação, tendo em vista sua posição na roda. Consideramos também as diversas coreografias realizadas na apresentação de algumas canções como jogos musicais que, dessa forma, e assim como as improvisações, constituíram-se não só como procedimentos isolados, mas também conjugados com a recriação das canções.
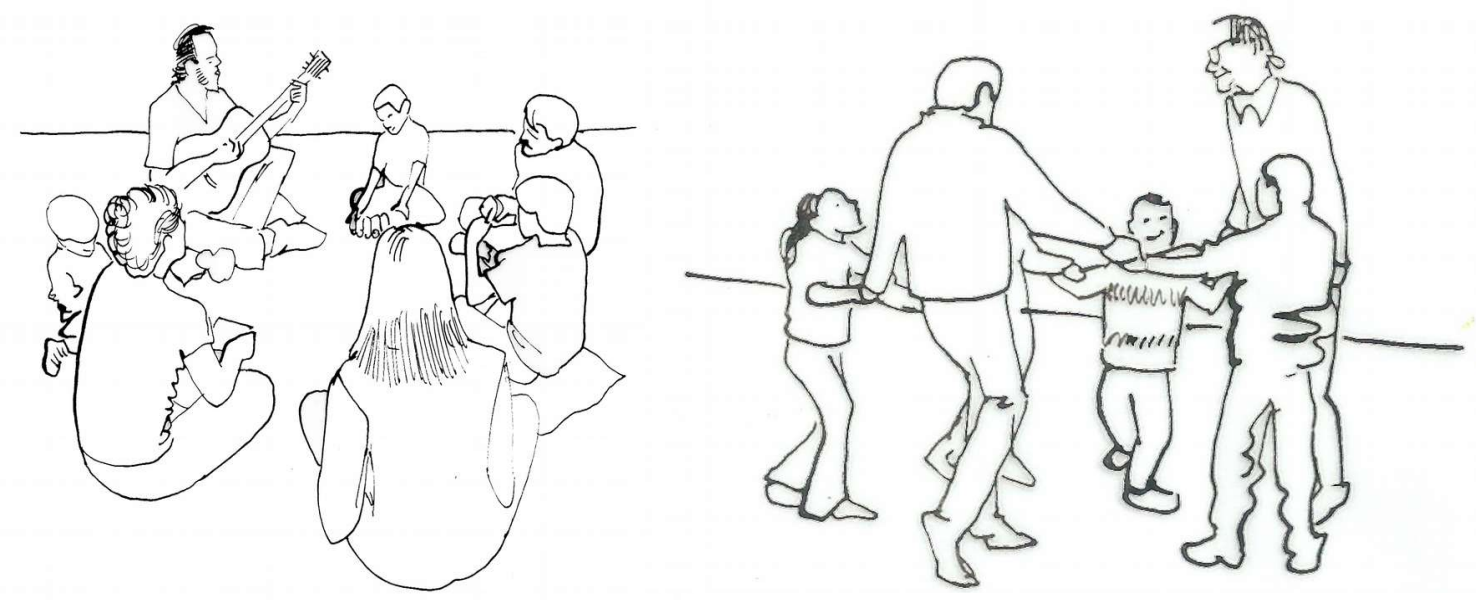

Figura 3 - Ilustrações da disposição do grupo em roda na oficina de música

De uma maneira geral, todos esses procedimentos eram realizados com os participantes sentados em um tapete ou colchonete, em uma roda (Fig. 3). Buscou-se sempre reunir o grupo nessa disposição, ou ainda mantê-la quando nos levantávamos, dando as mãos e formando uma roda.

Apesar da presença de improvisações e jogos musicais, a recriação de canções ocupou a maior parte das sessões. As canções eram primeiramente apresentadas pelo pesquisador, acompanhadas do violão, e aquelas que eram mais bem recebidas pelos participantes, seja porque eram reconhecidas ou solicitadas, ou porque se considerou que produziam um efeito clinicamente relevante a partir dos indicadores utilizados, eram reapresentadas nas sessões posteriores (ANEXO B). Essa seleção de canções foi compilada em um disco e uma cópia foi distribuída para as crianças quando elas entraram no período de férias escolares do mês de julho e não seriam atendidas. Elaborou-se também um encarte (Fig. 4), que foi pintado por cada criança durante o grupo da manhã e serviu de capa para a caixa dos respectivos discos. 


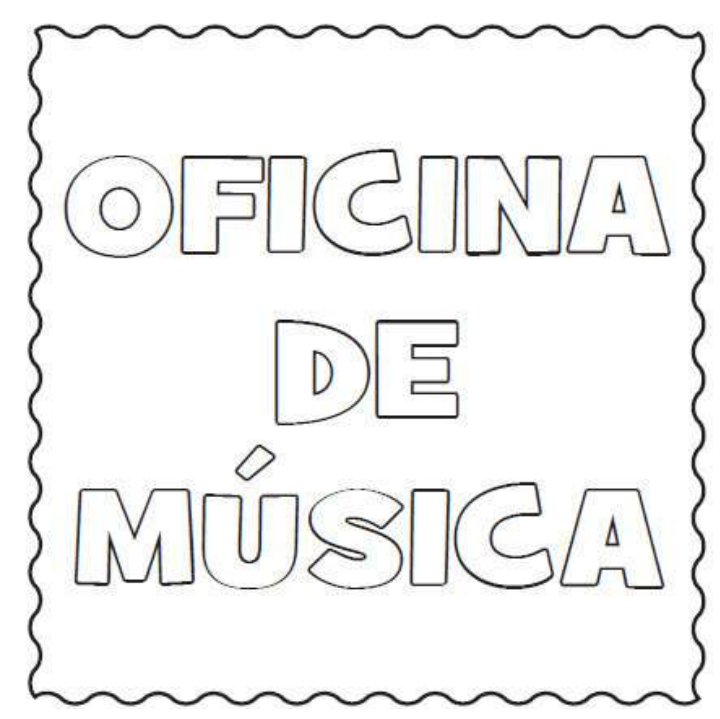

Figura 4 - Encarte do disco distribuído aos participantes

\subsection{Registro e análise de filmes}

As sessões da oficina foram gravadas com uma câmera de vídeo digital e o material foi transferido para um computador pessoal para análise posterior. Os vídeos foram analisados em momentos distintos da pesquisa: para as reuniões de supervisão, em que trechos das sessões eram empregados para apoiar as discussões; na edição de um vídeo de fim de ano, em que cenas foram selecionadas para serem apresentadas aos participantes e seus pais; na elaboração dos estudos de caso, nos quais as imagens possibilitam a ilustração de um argumento ou a melhor compreensão de algum evento específico. Essas repetidas visualizações do material permitiram ao pesquisador uma familiaridade com os eventos ocorridos e o acompanhamento do processo terapêutico como um todo.

Durante a elaboração dos estudos de caso, todo o material reunido foi visto e anotado minuto a minuto. Alguns segmentos foram selecionados para uma análise mais detalhada porque poderiam oferecer uma melhor compreensão de dados que dificilmente seriam captados durante as sessões ou mesmo na reprodução da gravação ou porque ofereciam uma ilustração dos eventos ocorridos nas sessões. Esses segmentos foram então analisados por meio do congelamento de imagens, reprodução em câmera lenta, quadro a quadro e em loop. 


\subsubsection{Microanálise}

A abordagem escolhida para a análise dos segmentos audiovisuais foi a microanálise, que pode ser definida como um método para investigar microprocessos, isto é, processos e mudanças ocorridos em períodos curtos de tempo. Ela permite acompanhar "mudanças mínimas nas relações ou interações entre pessoas ou mudanças mínimas na música e nas forças dinâmicas" (WOSCH; WIGRAM, 2007, p. 14) que ocorrem em uma situação clínica. A duração dos segmentos analisados é variável, e um processo pode ser acompanhado ao longo do tempo, com diversas microanálises sendo feitas para diferentes eventos.

Nos últimos anos, as pesquisas que empregam a microanálise e seus resultados têm se difundido em diversas disciplinas como Comunicação (BATESON, 1951, 1972; BIRDWHISTELL, 1952, 1970), Musicoterapia (HOLCK, 2002), Psicoterapia (SCHEFLEN, 1960, 1963; BEEBE, 2005), Psicologia do Desenvolvimento (STERN et al., 1985; TREVARTHEN; DANIEL, 2005) e Psicologia da Música (TREVARTHEN; MALLOCH, 2009). A microanálise permite o exame dos contornos das interações que não são visíveis quando a transcrição escrita é o único meio de registro. Ela oferece, portanto, uma ferramente mais poderosa que os métodos analíticos etnográficos ou de conversação, usualmente empregados em estudos da interação social. Ela pode superar, inclusive, problemas no registro do comportamento comunicativo de crianças com dificuldades de comunicação verbal e não-verbal na observação em tempo real.

As microexpressões foram descobertas por Haggard e Isaacs (1966) em um estudo de filmes cinematográficos de horas de psicoterapia, em que buscavam sinais de comunicação não-verbal entre o paciente e o terapeuta. Eles as descreveram como expressões "micromomentâneas" e involuntárias de emoção que podem ocorrer quando um indivíduo experimenta uma emoção forte, mas tenta esconder seus sentimentos. Sua duração é muito mais curta que as expressões faciais normais, girando ao redor de 1/15 ou 1/30 de segundo. Ao contrário de expressões faciais normais, eles descobriram que é difícil produzir ou neutralizar voluntariamente as microexpressões, ainda que elas estejam relacionadas à capacidade de reconhecimento das emoções do outro.

No mesmo ano, Condon e Ogston (1966) empregaram técnicas cinematográficas para o estudo do comportamento humano em busca de regularidades comportamentais em indivíduos mentalmente saudáveis e doentes. O resultado foi que tanto o comportamento normal 
quanto o patológico eram compostos de regularidades. Os primeiros apresentavam uma harmonia consistente entre fala e movimento corporal, o que sugeria um organismo altamente integrado, enquanto pacientes esquizofrênicos apresentavam comportamentos igualmente regulares, porém sem sincronia entre fala e gestos corporais. Eles denominaram essa nova área de investigação de microcinética (microkinesics).

Em seguida, Condon e Ogston (1967) dedicaram-se ao estudo das interações no nível de frações de segundo ocorridas ao longo de processos terapêuticos. Eles examinaram um filme de quatro horas e meia com sessões de uma terapia de casal, quadro a quadro, com cada quadro durando $1 / 25$ de segundo. A partir dessa microanálise, foram identificados micromovimentos interacionais que se combinavam em microrritmos. Um exemplo era o modo como a mulher movia seu ombro exatamente como as mãos do marido haviam sido erguidas.

Essa abordagem ganhou progressivamente mais adeptos nos anos 70, quando começaram os primeiros estudos de vídeos de troca comunicacional (BATESON, 1972; BIRDWHISTELL, 1970), em que elementos da troca comunicativa e mudanças da configuração dos movimentos corporais que acompanham a fala foram evidenciados. Em um estudo com bebês e seus cuidadores, Condon e Sander (1974) descobriram que o recém-nascido move o corpo de uma maneira precisa e sincronizada de acordo com as mudanças da fala do adulto. Evidências dessa "dança" foram encontradas desde o primeiro dia de vida, o que levou a uma revisão das teorias do desenvolvimento que pregavam um isolamento do bebê como receptor passivo das ações dos adultos, em favor de uma defesa da participação do recém-nascido em diversas formas de organização da interação. A sincronia entre a mobilidade do bebê e os eventos de fala de seu cuidador indicavam a existência de um processo de interação linguís tico-cinésico (linguistic-kinesic), e uma base empírica para o estudo da aquisição de linguagem.

A relação entre micromomentos e microexpressões e o conjunto mais amplo dos comportamentos humanos ainda é um ponto que merece discussão. Para Bateson (1996), a dimensão microscópica reflete a macroscópica, isto é, os ciclos mais longos são repetições ampliadas ou reflexos repetidos de padrões encontrados nos detalhes menores. Um dos resultados da microanálise seria, portanto, um registro de pequenas quantidades de dados capazes de conduzir a insights sobre as interações humanas que não poderiam ser obtidos de outra maneira, nem mesmo pela observação a longo prazo ou a reconstrução anamnésica.

Igualmente, a microanálise de filmes, associada ao estudo de problemas no desenvolvi- 
mento de crianças pequenas, vem provocando uma revolução com relação à compreensão sobre o autismo (BRASIL, 2013). A primeira dessas pesquisas, realizada por Massie (1978), ao investigar filmes caseiros com bebês que mais tarde foram diagnosticados com autismo, mostrou claramente os estados de sideração dos pais ante a falta de respostas do filho, fornecendo uma base empírica à crítica da noção de que a síndrome se relacionava com cuidadores frios ou pouco afetivos. Outras pesquisas com filmes caseiros reforçam a importância das primeiras interações diádicas em seu desenvolvimento psíquico. Em uma amostra de vídeos gravados apenas durante o primeiro ano de vida, Muratori e Maestro (2007a) encontraram menos respostas às tentativas de suas mães de estabelecer interações em crianças com autismo que crianças que não desenvolveriam a síndrome. No entanto, algumas crianças com autismo podiam demonstrar comportamentos sociais, como a troca de olhares, sorrisos e até mesmo a atenção compartilhada ou ações de apontar um objeto, mas a sua frequência já era menor que o das outras crianças.

\subsubsection{Transcrições}

Os segmentos escolhidos foram descritos tanto em linguagem escrita quanto em partituras musicais e gráficos de análise acústica. O procedimento adotado para o segundo caso foi a audição dos segmentos e a transcrição de cada instrumento, um a um, seguido pela confirmação e correção do que havia sido transcrito.

Segundo Bergstrøm-Nielsen (2009), as ferramentas descritivas podem servir a dois objetivos principais na investigação da linguagem musical em processos terapêuticos. Elas podem sugerir como era a música em determinado momento, dando uma imagem mais vívida, e permitir a verificação e o exame crítico dos dados empíricos que proporcionaram determinada conclusão. Em segundo lugar, elas podem gerar e ordenar uma memória das sessões, de modo a acompanhar o processo terapêutico em sua sequência. É possível ainda pensar que as descrições permitem a leitura do eventos clínicos praticamente ao mesmo tempo em que eles ocorrem, sendo que a sua dimensão temporal é a grande contribuição aos processos descritos.

A comunicação verbal pode descrever de uma maneira extremamente flexível os eventos ocorridos ao longo de uma sessão. A notação musical, por sua vez, inclui na descrição uma 
apresentação bastante precisa do modo como os eventos se distribuem no tempo, e se organizam em relações de continuidade, simultaneidade e causalidade ao longo desse eixo. Para o leitor com algum conhecimento de teoria musical, elas podem oferecer uma contribuição enriquecedora dos processos interativos que acompanhamos no trabalho clínico Um glossário com os termos musicais empregados é apresentado ao final (ANEXO C), com o objetivo de facilitar a leitura. Pode-se igualmente acompanhar uma gravação dos segmentos transcritos no CD anexo (ANEXO D). Para garantir o sigilo da identidade dos participantes, assim como no caso das ilustrações, os momentos em que algum nome era pronunciado foram suprimidos.

$\mathrm{Na}$ leitura das partituras, algumas observações devem ser levadas em consideração. Em primeiro lugar, cada pauta foi usada para um instrumento, indicado no início da transcrição, acompanhado do nome de quem o toca entre parênteses. Nos sistemas seguintes, essa indicação foi abreviada. A numeração dos compassos está indicada no primeiro compasso de cada sistema, acima do colchete. Quando a duração de um segmento não podia ser deduzida de seu andamento, uma indicação do tempo transcorrido foi adicionada. Em alguns segmentos, havia outras pessoas tocando e cantando que não foram incluídas na transcrição, sendo transcritas apenas as vozes e instrumentos diretamente ligados ao que se queria demonstrar em cada caso. Em cada pauta foram transcritos os eventos sonoros referentes a um instrumento, porém, no caso do xilofone, pelo fato de contar com um tambor móvel que se fixava na estrutura do instrumento, uma pauta de percussão separada foi incluída, unida à pauta que representa as teclas por uma chave.

Outras anotações, como movimentos corporais e vocalizações, foram indicadas acima da pauta correspondente a cada participante. Comportamentos não-musicais considerados relevantes ao longo dos segmentos transcritos também foram anotados, acima do compasso em que ocorreram. Buscou-se com isso enriquecer a descrição daquilo que acontecia, ainda que evidentemente uma seleção teve de ser aplicada. Em um sentido geral, esse processo foi guiado pelas necessidade de reforçar alguns argumentos das discussões relacionadas a cada passagem. As vocalizações são indicadas por aspas. No caso da transcrição das letras cantadas, elisões entre duas palavras são indicadas pelo sinal $~$, indicando que se pronuncia juntos os sons das letras unidas pelo traço, apesar de fazerem parte de palavras diferentes.

A qualidade do registro era variável. De uma maneira geral, foi possível compreender qual som correspondia a cada pessoa e instrumento. $O$ vídeo auxilia nessa tarefa, mas não em todos os momentos. Houve casos em que uma pessoa ou instrumento não estavam presentes 
ou apareciam de costas no registro visual, mesmo que por alguns instantes, e apenas o som podia ser ouvido. As análises foram realizadas conforme aquilo que podia ser avaliado como sendo uma produção de tal ou tal pessoa, deixando de lado o material que apresentava algum tipo de dúvida com relação à sua origem.

\subsubsection{Ilustrações}

Em algumas análises, fotogramas isolados ou em sequência foram usados para ilustrar algum argumento. Essas imagens foram submetidas ao ilustrador Rômulo Alexis, quem as preparou para que fossem incluídas no texto e permitissem um melhor acompanhamento da leitura. Esse processo visa cumprir com as diretrizes éticas previstas no Termo de Consentimento Livre e Esclarecido, garantindo que a identidade dos participantes seja mantida em sigilo.

\subsubsection{Análise acústica e espectral}

A análise acústica (MALLOCH, 1999) foi empregada todas as vezes em que se buscou um maior detalhamento das qualidades acústicas de um segmento. Ela foi usada tanto na análise de eventos musicais quanto vocais, com o objetivo de fornecer uma avaliação quantitativa e qualitativa da musicalidade comunicativa, isto é, das formas e qualidades expressivas no tempo que caracterizam e imprimem sentido aos sons. Nesse sentido, os registros sonoros selecionados foram submetidos ao software Praat (BOERSMA; WEENINK, 2012), ferramenta de análise acústica desenvolvida pela Universidade de Amsterdã que gera três gráficos quantitativos para cada segmento. Esses segmentos também estão disponíveis no CD (ANEXO C). Os espectrogramas são representações gráficas da frequência fundamental e harmônicos das emissões sonoras, medidos em $\mathrm{Hz}$ e tendo as verbalizações discriminadas abaixo do espectrograma. Quanto mais intenso for um harmônico, mais forte será a sua tonalidade na escala de cinza. Os gráficos de intensidade, por sua vez, representam a força com que os sons são emitidos, sendo medidos em $\mathrm{dB}$. Por último, os gráficos de pitch indicam a frequência fundamental do 
som emitido, isto é, a nota que de fato escutamos, que, no caso da voz, é definida pelo número de vibrações por segundo produzidas pelas cordas vocais.

Ainda a respeito da voz, a análise acústica e espectral pode oferecer informações objetivas a respeito da qualidade vocal, isto é, o aspecto subjetivamente percebido. Este pode ser descrito em termos da percepção auditiva como normal/anormal, bom/ruim, brilhante/escuro, oral/nasal, etc., características que podem indicar um estado emocional ou um elemento diferencial de um indivíduo ou grupo de indivíduos. A qualidade da voz corresponde a um nível extralinguístico da comunicação, sendo determinada pelas características físicas e fisiológicas incluídas na produção da voz, como fatores orgânicos, gênero, idade, extensão vocal, etc.

A análise acústica das interações sociais vem sendo empregada na pesquisa em Psicologia do Desenvolvimento (p. ex. FERNALD, 1985; FERNALD; KUHL, 1987; TREVARTHEN; MALLOCH, 2009) e Psicopatologia Infantil (p. ex. MURATORI; MAESTRO, 2007b; LAZNIK et al., 2005), e seu uso é recomendado por ser capaz de fornecer mensurações objetivas, tanto quantitativas quanto qualitativas, de parâmetros antes subjetivamente definidos como timbre, coordenação e sincronia. 


\section{ESTUDOS DE CASO}

Apresentamos a seguir os estudos de caso individuais das crianças participantes da pesquisa. Eles foram elaborados a partir de dados colhidos na recepção, cenas ocorridas ao longo das sessões de atendimento individual e em grupo, seguidas de análises e reflexões clínicas sobre as intervenções planejadas e realizadas, bem como as discussões feitas pela equipe clínica nas reuniões após a realização dos grupos, das quais eventualmente participaram outros profis sionais em contato com as crianças. Tratou-se também de discutir, para cada criança, uma ou mais orientações de tratamento a partir dos procedimentos da pesquisa.

Para a construção dos estudos de caso, foram utilizadas informações provenientes: da entrevista de recepção das crianças e familiares, realizada pela psicóloga do Núcleo de Educação Terapêutica; dos relatos dos atendimentos, colhidos pelos alunos da graduação que atendem as crianças individualmente; e relatos das sessões do grupo da manhã e da oficina de música, pro duzidos semanalmente e de maneira alternada entre os membros da equipe.

As categorias da Avaliação Psicanalítica aos 3 anos (AP3) (KUPFER et al., 2008) são usadas como indicadores clínicos e orientam a percepção e a leitura dos eventos ocorridos no atendimento. Ainda que tenha sido pensada para a identificação de sinais de problemas no desenvolvimento para crianças com a idade de 3 anos, esse instrumento mostrou-se adequado para a avaliação de crianças maiores e a leitura do processo de constituição do laço social na iniciação científica sobre a oficina "Música, Corpo e Movimento" (LIMA et al., 2008). As quatro categorias da AP3 são: o brincar e a fantasia, sendo o primeiro considerado forma de expressar o segundo, oscilando entre a ausência de uma produção imaginária à presença de uma narrativa; o corpo e a sua imagem, vinculados à construção de um imagem corporal que possa ou não ser reconhecida como tal e separada de seu exterior; a manifestação diante das normas e posição frente à lei, isto é, a observância de limites e a restrição dos próprios impulsos em concordância com a situação, bem como a marcação de tempos e atividades; a fala e a posição na linguagem, medida pelo lugar a partir do qual o sujeito se representa a si e suas relações com os outros. Além de fornecer os eixos de leitura das unidades selecionadas como forma descritiva de avaliação clínica, a AP3 pode ser usada também na caracterização dos participantes, na ilustração dos casos e na análise de quaisquer outros conteúdos que sejam de relevância clínica. 


\subsection{William}

William é uma criança de nove anos, trazida ao núcleo pelos pais e uma "tia”, ambas mulheres com o mesmo come. A família traz um diagnóstico de distúrbio global do desenvolvimento, dado pela pediatra, e diversas queixas das escolas pelas quais o menino passou, desde falta de atenção até violência com outras crianças. William se revela bastante agitado, com dificuldades em manter-se quieto, e desajeitado nos movimentos de seu corpo, que parece grande para a idade. Apresenta também um discurso sem coerência, muitas vezes parecendo reproduzir falas ouvidas na televisão e juntando significantes em neologismos, como "pia-esgoto", "peixe-lagosta" e "tambor-apito", ou aglutinações, como "tambeiro", mistura de tambor com pandeiro. Mais tarde na entrevista, entende-se que a "tia”, na verdade, é a segunda companheira do pai, com a qual este esteve após separar-se da mãe de William. Pelo fato de ter se afeiçoado ao garoto, mesmo após o fim do relacionamento, ela manteve um contato estreito, acompanhando seu tratamento e escolarização, eventualmente oferecendo-lhe presentes como roupas e assinatura de TV a cabo. Essa postura maternal da "tia" é recebida com ambiguidade pela mãe biológica de William, que aceita esse apoio ao mesmo tempo em que ele parece suplantar sua própria condição de mãe e sua relação com a criança. De alguma forma, essa configuração vincular parece dificultar para William a possibilidade de encontrar o seu lugar na estrutura familiar. Isso fica exemplificado pela forma com a qual o significante "tia" se estende a todas as demais pessoas, que William chama de "tio" ou "tia”, e não pelo nome próprio.

Um dado familiar importante é a relação de William com a representação paterna, policial de profissão. O pai representa para ele uma verdadeira figura de terror que o paralisa, muitas vezes fazendo-o chorar quando lhe dizemos que deve se comportar ou que, do contrário, teremos que chamá-lo na sala de espera. Esse terror não se confirma com o que temos acompanhado, dado que o pai se mostra bastante interessado no filho e mesmo carinhoso com ele, como nas situações em que o encontramos fazendo-lhe carinhos na cabeça enquanto esperam o início do atendimento.

Na primeira sessão da oficina (10/05/13), após nos sentarmos em roda, foi proposto um jogo musical de apresentação no qual todos diríamos nossos nomes ajustando-os ao grupo de colcheias de uma célula rítmica derivada da marcha, composta por duas semínimas e três semicolcheias seguidas de uma pausa (Fig. 5), com o segundo tempo mais forte. Para começar, a 
modo de exemplo, cantei meu nome nas duas colcheias, "Da-niel", batendo palmas nas três semicolcheias e repetindo uma segunda vez.

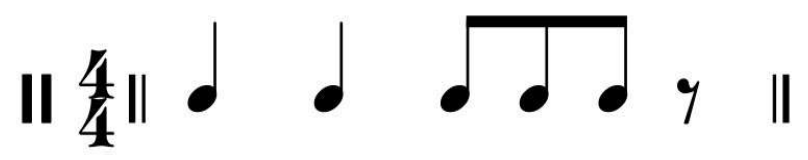

Figura 5 - Célula rítmica do jogo musical de apresentação dos nomes na oficina de música de 10/15/13

Apesar de aparentemente se tratar de uma tarefa simples, pude verificar naquele momento que ela apresentava exigências cognitivas e sociais às quais algumas crianças não puderam fazer frente. Pablo não pôde dizer seu nome, apesar de certo esforço. Camila se manteve alheia e, apesar de permanecer na roda nesse momento, se concentrava em despejar sobre uma pequena montanha de folhas de papel uma grande quantidade de cola branca, de modo que o grupo tratou de apresentá-la. Sofia conseguiu encaixar seu nome na célula, demonstrando sua satisfação com um sorriso.

Já para William, que pôde apresentar-se mediante esse jogo, aquela célula teve um efeito ainda mais intenso e duradouro. Naquela mesma sessão, por diversas vezes ele a repetiu incessantemente, soprando em um apito as semínimas e percutindo com as baquetas em um tambor as colcheias, às vezes chamando a atenção para essa performance com um "Olha tio!". Essa demonstração acontecia tanto na roda no chão quanto de pé, nas cadeiras ou em movimento, sendo acompanhada de uma agitação motora que o impedia de sustentar o ritmo. Esse ostinato parecia tomá-lo por completo, prolongando-se indefinidamente após surgir entre uma canção ou improvisação, até o ponto em que pedíamos que ele parasse.

A reiteração por si só da célula me deu alguma ideia do que poderia ser a marca de ex cesso da relação que William estabelece com o Outro. A impressão é que a relação que ele estabelecia com o grupo se mantinha apenas pela via da saturação, forçando-o a uma continuidade espaço-temporal em uma série praticamente infinita de um termo só. Os motivos para essa necessidade ainda não eram claros, mas os efeitos para o grupo não eram animadores já que William ocupava o centro das atenções e tornava difícil aos demais realizar qualquer atividade. A célula rítmica, por outro lado, parecia haver lhe tocado algo importante, talvez algo da ordem de uma identidade sonora. Infelizmente, não soube manejar essa emergência. Sem perceber sua importância, ela me parecia durante as sessões mais como uma estereotipia que impedia a realização da oficina e mesmo a participação de William na oficina. Isso foi discutido na reunião clínica, onde discutimos a possibilidade de nos orientarmos a suprimir aquele compor- 
tamento ou dar-lhe um novo sentido.

$\mathrm{Na}$ segunda sessão (17/05/13), William retomaria em diversos momentos a repetição da mesma célula, desta vez empregando uma variedade de duplas de instrumentos. Primeiramente, na hora de apresentar o instrumento escolhido, ele diz "bateria-apito". Em seguida, ele coloca o apito na boca e o sopra com força, rufando ao mesmo tempo o tambor. A força e amplitude dos movimentos das batidas é tão forte que ele chega a dar numa baquetada no apito, que cai em cima do tambor e entra no meio dos golpes. Ele retorna o apito à boca e segue, porém espera com uma pausa na hora em que os demais apresentam seu instrumento. Depois da canção de abertura, ele retoma aquele ritmo, soprando as semínimas no apito e percutindo as colcheias com golpes da baqueta direita, apesar de manter a esquerda em posição para tocar. Perguntamos a ele então que música era aquela, mas ele não para de tocar. Beatriz pede então que ele explique para Paula e Mathias que aquele ritmo havia sido usado para nos apresentarmos na semana anterior. William prossegue no ostinato, mas em algumas repetições as semínimas são substituídas por uma mínima. Peço que ele tire o apito da boca para falar, o que ele de fato faz, mas diz apenas "sei lá". Insistimos em que ele explique, mas ele hesita um pouco e volta a pôr o instrumento na boca e a tocar.

Proponho então que cantemos a apresentação dos nomes, usando os estalos e as palmas, e o grupo começa a repetir. William diz então que esperemos, porque ele iria começar. Respondo que já havíamos começado, mas ele entra fora do ritmo e o desorganiza. Sem conseguir marcar novamente um pulso comum, digo: "A gente precisa fazer de um jeito só. Você quer começar? Então vai lá”. Ele começa e pergunto a ele o que fazíamos enquanto tocávamos. Ele não responde, e Beatriz o toca no joelho dizendo: "Quando um fala, o outro escuta". Como ele continua, Beatriz responde por ele e diz que falávamos o nosso nome.

Sinto que a situação é angustiante para todos, frente à intensidade dos sopros e batidas de William e a dificuldade de iniciar o jogo. Peço então que ele me dê o apito, com o argumento de que com o instrumento ele não poderia dizer o nome. Ele me dá, mas agarra um ou tro em seguida. Ao chegar a sua vez, Beatriz lhe tira o apito com cuidado, mas ele fica mudo e agarra novamente o apito. Peço que ele me dê o instrumento e tentamos mais uma vez, porém ele não diz o nome. Acabo falando por ele: "Wi-lliam", mas digo que é ele quem deve falar. Ele abaixa a cabeça por alguns momentos e se lança em direção ao Pablo, que está com um terceiro apito, parecido com aqueles de caça de patos. Ao perceber o movimento, Beatriz se coloca no meio e William diz: “Espera”. Ela pergunta: "Espera o quê?”. Mas ele faz apenas um grunhido: 
"uhhhh", e apoia a cabeça no tambor.

A ansiedade gerada pela cena parece aumentar ainda mais. Mathias, de costas para a roda, começa a bater no xilofone e dá um grito. Decido então que é melhor falar o nome de William por ele e prosseguir com o jogo. Ele rufa o tambor com força, o que parece com uma descarrega de raiva. Passamos para o Guilherme, que estava ao seu lado, e William recupera o apito. A célula continua sendo tocada sem parar, e parece gerar uma agitação crescente em William, que começa a gritar. Ele coloca um outro tambor ao lado do primeiro e toca um com cada baqueta enquanto cantamos "O pato pateta". Parece reproduzir ali a bateria, que já havia anunciado no começo da sessão. Na hora da coda, após cantarmos "E foi pra panela", ele atira o apito com a boca e grita: "E morreu". Pergunto o que havia acontecido e ele grita, agora com o apito de volta na boca, "Foi frito e morreu", batendo violentamente nos tambores.

Peço os dois tambores e ele me entrega, mas se levanta e vai até a sacola de instrumentos, voltando com um gonguê de coco e a flauta doce. Ele se senta e pergunta: "Que tal assim, ó?", enquanto toca a célula, soprando as semínimas na flauta e batendo as colcheias com as metades de coco no chão. Proponho então uma canção que usava aquele ritmo. Pedi que ele sustentasse a célula enquanto cantava "Um, dois, feijão com arroz", o que foi acompanhado pelo res tante do grupo. William pareceu pouco surpreso com a canção e já na segunda repetição não pôde ajustar o ritmo a um andamento que permitisse que cantássemos. Proponho que ele toque e que nós o acompanharíamos, mas isso faz com que ele deixe de tocar, junte as duas metades do gonguê e, dizendo que parecia um ovo, golpeie a própria cabeça. Ele se levanta, deixando a roda em busca de outro instrumento, porém encontra a sacola vazia.

Começo a cantar a canção de abertura do programa de televisão "Cocoricó” e ele grita por duas vezes: “Onde está o apito?”, levando as duas mãos à cabeça, com uma expressão de desespero no rosto. Ele vai para um canto da sala e fica nos olhando, mantendo as mãos sobre as têmporas, mas após alguns compassos volta para a roda dançando. Quando se senta, encontra um apito e com um chocalho volta a repetir a célula e nos pergunta "Que tal assim, ó?", agora com um chocalho em uma mão e um caxixi na outra.

É difícil manter o grupo coeso, as demais crianças parecem se dispersar ou olhar para William, sem se engajar naquilo que ele toca. Pergunto a ele: “Já tocamos essa, não?", propondo fazer outra canção e voltar à apresentação dos nomes no final. Começo então a tocar "Banho é bom", do programa Castelo Rá-Tim-Bum, e William continua com sua célula. Porém, na segunda estrofe, ele a modifica no ritmo da canção, adaptando-a para marcar a pulsação (Fig. 6). 

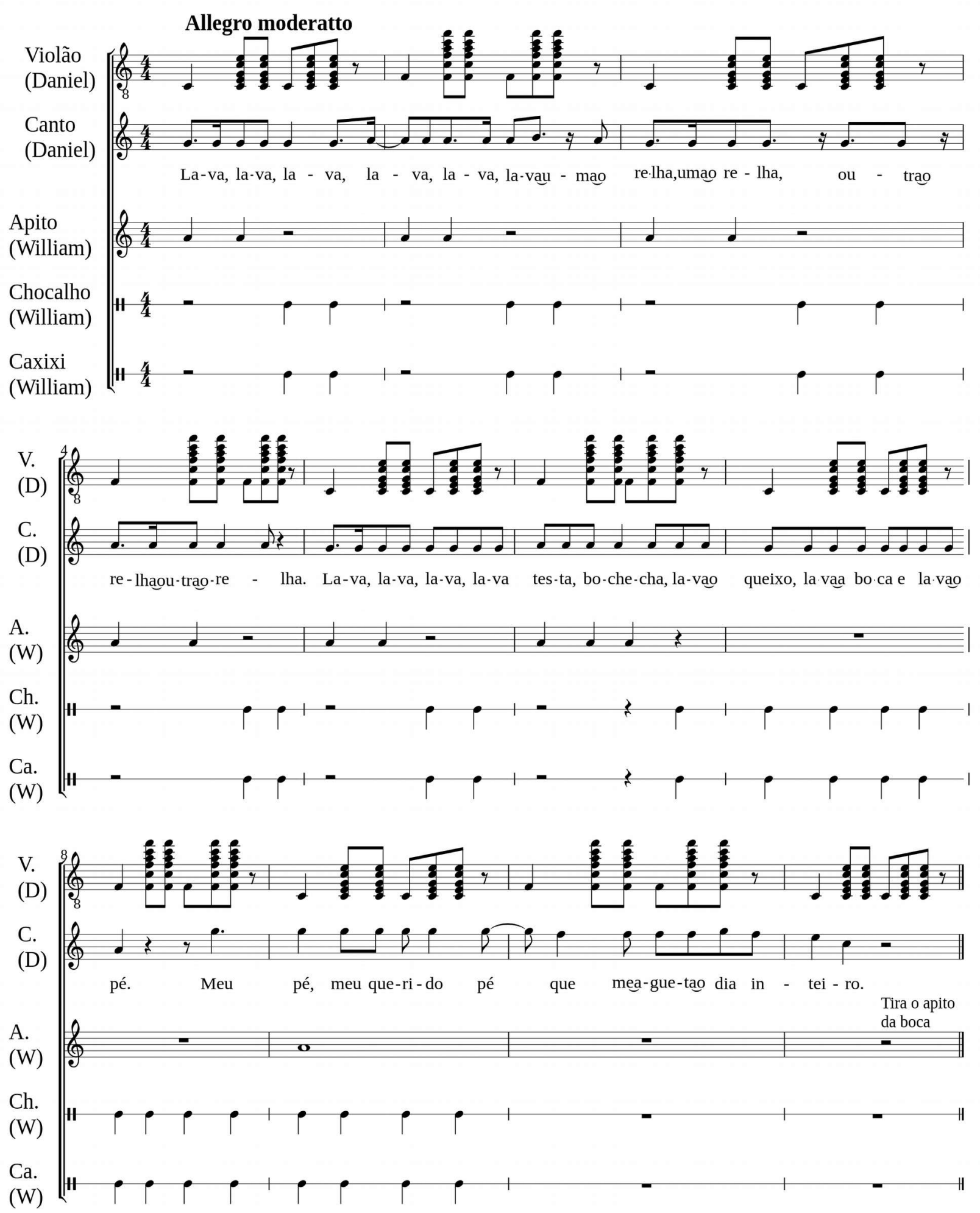

Figura 6 - Transcrição de trecho da recriação da canção "Banho é bom” na oficina de música de 17/05/13

Durante os cinco primeiros compassos, ele mantém a estrutura de alternância da célula original entre os dois grupos de duração, tocando cada um com um tipo de instrumento, ainda que tenha substituído as colcheias por semínimas. Isso não parece ser algo que ocorre com facilidade para ele, e após equivocar-se no sexto compasso, ele passa a marcar o pulso com os 
dois chocalhos. A marcação do pulso tampouco se estende por muito tempo, e é acompanhada por uma pausa, seguida do movimento de tirar o apito da boca. É o primeiro momento da ses são, após aproximadamente 20 minutos, em que ele se acalma e fica em silêncio. Ele olha ao redor e oferece seu apito, primeiro a Guilherme, que o recusa, e depois a Beatriz. Ela diz que já tem um apito, mas ele o deixa cair em seu colo. Ele volta ainda à célula quando termina a canção, mas agora com poucas repetições, tocando com uma força muito menor. E, quando proponho que a cantemos novamente, ele acompanha com o chocalho, muito mais interessado naquilo que os outros estão tocando. $\mathrm{O}$ ato de incluir aquela célula em outra música lhe altera o caráter e produz um efeito em William. O mesmo acontecerá na sessão seguinte, quando ele a incorporará na canção "O pato pateta”.

Apesar de a célula não aparecer mais naquela sessão, William continua a golpear os instrumentos com violência e a jogá-los para cima. Beatriz intervém dizendo: "Tem horas que a gente escuta e tem horas que a gente toca”. Voltamos a tocar e a cantar, mas ele não nos acompanha, se levanta e fica com os braços cruzados e a cabeça para baixo. Estamos fazendo a coreografia da canção, apontando as partes do corpo de que fala a canção, e ele começa a nos atacar com a sacola de instrumentos. Tento convidá-lo para brincar conosco, mas ele volta à posição anterior, com os braços cruzados e a cabeça para baixo. $\mathrm{O}$ mesmo ocorre quando ele se aproxima de Beatriz com um sorriso, mas retorna ao canto quando ela diz "Olha os seus instrumentos aî", e chuta o chocalho, que rola uns 20 centímetros. Por fim, ele avisa que vai embora, saindo pela porta. Isso provoca uma mudança na expressão de Pablo, que parece estar atento a tudo o que o companheiro faz, mas não tem nenhum efeito em Mathias, que o vê sair e continua a tocar o xilofone. Após um minuto, William volta com um barquinho amarelo e brinca com ele em uma cadeira fora da roda, falando alto e chamando a atenção do grupo. Pablo pede a Beatriz para ir brincar com William, mas ela diz que aquele era o momento de tocar. Já Mathias, apesar de parecer ignorar o que ocorre, também parece aumentar a intensidade com que percute o xilofone na medida em que a brincadeira de William sobre a mesa se torna mais violenta e barulhenta. Em lugar da precisão sobre as teclas, seu modo de tocar se enche de glissandi e clusters.

O trabalho clínico com William é difícil de ser sustentado no grupo, em um padrão que será lentamente alterado ao longo do tratamento. Em primeiro lugar, ele não se engaja com as atividades que são propostas, dispondo-se a fazer somente aquilo que quer. Quando contrariado, ou quando os outros não se engajam em suas propostas, ele se levanta e permanece fora da 
roda, chamando a atenção ou agredindo os demais, chutando e arremessando objetos. Ao mes mo tempo em que traz uma miríade de imagens, palavras, músicas, etc., há uma dificuldade tanto dele quanto nossa - de se focar em qualquer uma dessas coisas, que dão constantemente lugar a novos elementos. Essa contradição entre uma riqueza de materiais e um desenvolvimento reduzido fica exemplificada em seu comportamento frequente de pedir músicas. Muitas vezes, essas peças não estavam no repertório do grupo naquele momento, e as improvisações que surgiam desses pedidos terminavam sendo incorporadas, como, por exemplo, a "Música assustadora" ou o motivo musical do filme "Tubarão". Outras vezes, no entanto, não conseguíamos identificar qual era a canção solicitada, e era apenas com muita dificuldade que ele conseguia nos transmitir o que queria, ou nos ensinar uma música nova. As alternativas eram, portanto, que todos improvisássemos, descobrir qual era a canção após algumas tentativas, ou que ele mesmo a inventasse. Nesse último caso, William dava provas da sua criatividade que nos divertiam a todos, como na sessão do dia 25/10/13, quando ele pede a música do "Banho é ruim" e canta o refrão da canção "Banho é bom", parodiando seus versos para "Banho é ruim, banho é ruim. Banho é muito ruim”. Apesar disso, o mais comum era que um pedido seu se transformasse em uma situação de frustração, sem que ele pudesse explicar o que queria ou que nós pudéssemos responder ao seu desejo.

Já os momentos de desbordamento às vezes se confundem com uma cota de agressividade que surge nos momentos em que ele atira os instrumentos para o alto ou tenta atacar fisicamente uma outra criança. Por outro lado, as situações em que ele claramente se concentra em uma atividade são aqueles em que a escrita ou a modelagem estão envolvidas. $\mathrm{Na}$ sessão de 20/09/13, por exemplo, encontro-o sentado sozinho em uma mesa, juntando cuidadosamente pedaços de massinha de $1,5 \mathrm{~cm}$ com o objetivo de montar uma minúscula escultura do personagem George, do desenho da porquinha Peppa. Nem mesmo Mathias, que sopra a flauta com força, e Sofia, que toca os cocos e dança a seu lado, são capazes de tirá-lo desse momento de concentração. O desenho é outra atividade em que há um cuidado maior e, em contraste com os movimentos desajeitados de preencher os espaços, ele pinta e colore com atenção, sem ultrapassar as margens dos desenhos. O rabisco é algo que o incomoda, e até mesmo o desespera. No atendimento individual, por exemplo, ele brinca com Juliana de fazer uma lista de materiais para serem levados a uma expedição, mas não suporta que ela risque o que foi escrito, brincando de checar a lista. De mesmo modo, em uma sessão do grupo da manhã, ele impede que se desenhem linhas ligando as bandeiras a seus respectivos países em um mapa pendurado na 
sala. Pensamos que quando o mapa ou a lista é danificado, é o próprio corpo de William que é de alguma forma machucado, o que explica esse terror associado ao rabiscar. A essa dificuldade se une a de aceitar a presença do outro no momento em que este tenta lhe oferecer uma borda por meio de ordens, repreensões, etc. Uma estratégia clínica é estabelecer com ele um combinado no qual uma palavra é escolhida para lembrá-lo dos limites, como vemos no exemplo a seguir.

Antes de o grupo da manhã terminar, Beatriz levou William para a cozinha, perguntando como poderiam fazer um acordo para que ele pudesse participar do grupo e não machucar as outras crianças. Como William não respondia, Beatriz sugeriu que ele dissesse uma palavra que ela pudesse usar para chamar a atenção dele. Depois de uma boa insistência, ele sussurrou algo baixinho: "sshsh". Pedindo que ele falasse mais alto, eles combinaram que seria "já chega" (Essa é uma expressão que ele mesmo usa em alguns momentos) (.. .) Como a Cami indicava o violão e dizia "não", Daniel deixou de tocar o instrumento e o deixou no chão. Nesse momento, William começou a reclamar que tocassem o violão, porque senão a música ficaria chata. A ausência do violão pareceu ser insuportável para ele que, nesse momento, levou as mãos às cabeças, dizendo "já chega, minha cabeça tá pegando fogo" (Relato do Grupo Terapêutico, 06/09/13).

Quando chamamos a sua atenção por algum motivo, ele nos ignora e abandona o que está fazendo, e muitas vezes escorrega para o chão como se nada estivesse acontecendo.

Nesse momento, a palavra não parece ter um efeito de barramento dos excessos de William. É sempre necessário retomar os combinados de não machucar e não destruir os brinquedos, mas essa retomada do que está instituído como lei para todos do grupo também não parece suficiente para o William. Ele não olha para quem está fazendo a função de apontar algum limite. Parece aguardar esse assunto terminar logo para voltar a fazer o que ele queria (Relato do Grupo Terapêutico, 13/09/13).

Algumas vezes, a palavra que barra parece ter algum efeito em William, e ele assume aí uma posição bastante diferente, aderindo ao corpo do outro, abraçando-o, muitas vezes com beijos, como ocorre nessa mesma sessão. Uma estratégia que descubro surtir um relativo efeito é chamar-lhe a atenção não apenas oralmente, mas aproximando-me fisicamente ou trazendo-o junto a mim, falando-lhe quase diretamente ao ouvido.

Com o tempo, outras formas do comportamento excessivo de William começam a se manifestar. Um desses comportamentos é a sua forma de tocar a flauta doce, instrumento do qual ele extrai uma numerosa quantidade de sons agudíssimos, soprando-a com extrema força e atingindo harmônicos elevados. Um exemplo é o que ocorre na canção "Atirei o pau no gato”, que recriamos na sessão do dia 24/05 (Fig. 7). 


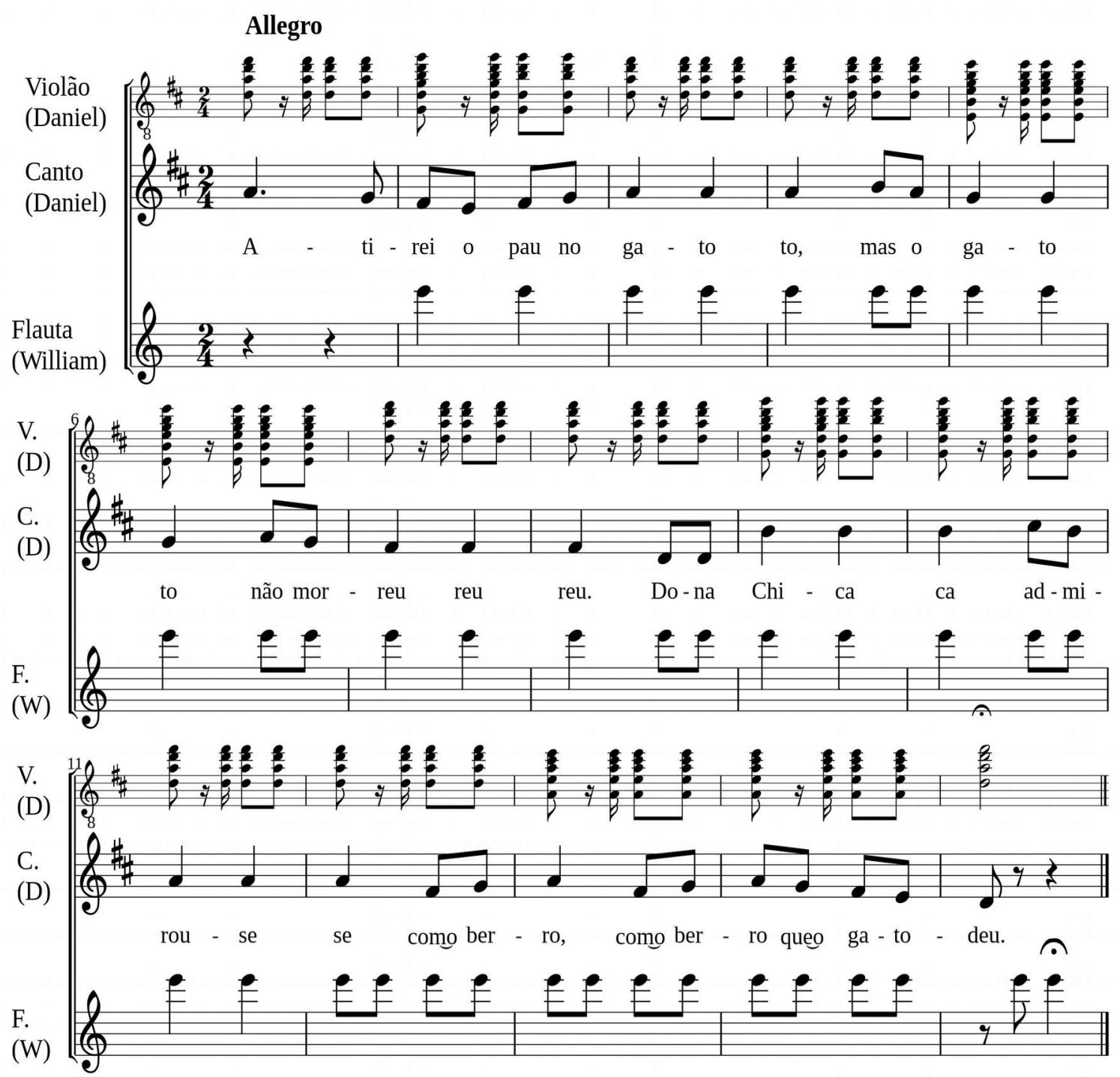

Figura 7 - Transcrição de trecho da recriação da canção "Atirei o pau no gato" na oficina de música de 24/05/13

As notas fortes no registro agudo são um elemento a mais para pensar a maneira como William não só se comunica, mas interage com os outros, ocupando todo e qualquer espaço que possa com seus excessos e transbordamentos. Mas elas indicam também outra coisa. Ao longo de quase todo esse segmento, é possível acompanhar como William praticamente repete na flauta o ritmo dos versos cantados. Essa análise nos permite pensar o sentido desse modo de tocar para além do registro sonoro, deslocando-o para o campo da linguagem oral. As notas aqui assumem o valor de palavras, e a força que ele imprime no instrumento é uma forma de gritar os versos, os quais ele não enuncia com a voz. Isso tem uma relevância clínica se consideramos que William, ao contrário das outras crianças que, ainda que poucas vezes, cantam comigo, não me acompanha com sua voz, além das dificuldades em comunicar-se verbalmente sobre as canções que deseja, por exemplo. 
Um outro exemplo desse modo de tocar o instrumento é na canção de abertura de "Thomas e seus amigos", um de seus desenhos animados preferidos, cujos personagens são locomotivas de trem (Fig. 8). Aqui, William toca o pandeiro acompanhando as sílabas dos versos.

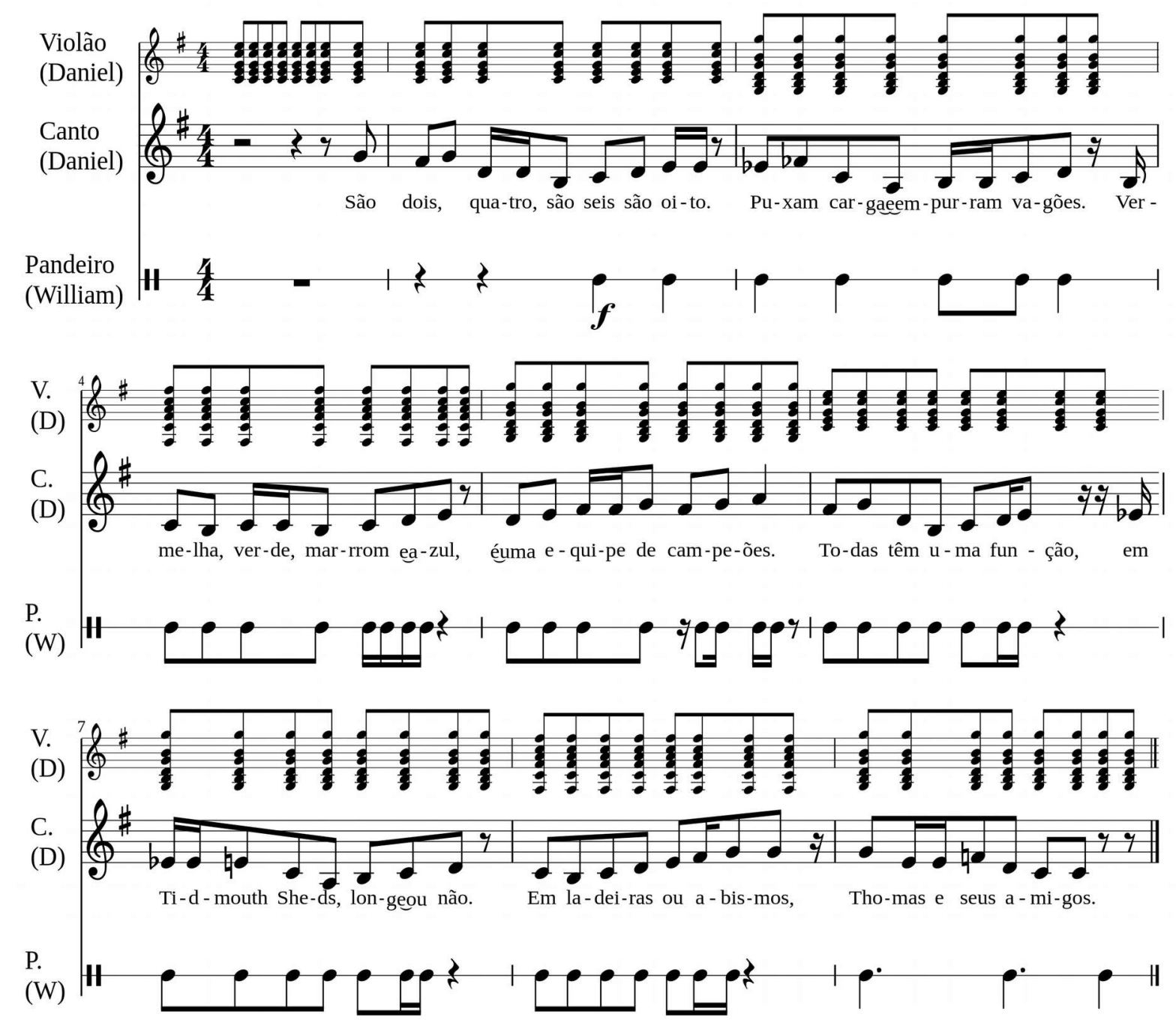

Figura 8 - Transcrição da recriação da canção "Thomas e seus amigos" na oficina de música de 06/07/13

Tanto é assim que descubro mais tarde que errei a maneira de cantar o último verso, que na verdade tem um ritmo mais parecido com aquele que William toca no pandeiro (Fig. 9). No desenho, as últimas sílabas da canção são cantadas em um ritardando, o que está mais de acordo com as semínimas pontuadas que William toca no pandeiro.

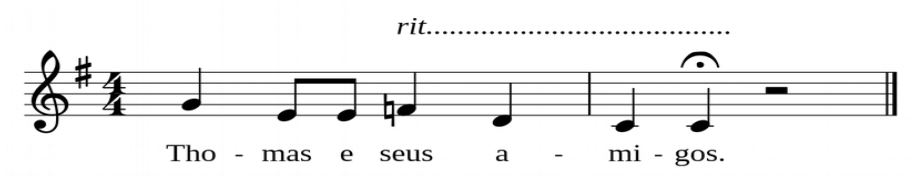

Figura 9 - Transcrição do final da canção de abertura do desenho "Thomas e seus amigos" 
A título de comparação, podemos acompanhar o modo como William e Pablo tocam os instrumentos de sopro quando fazemos uma segunda repetição da canção (Fig. 10). Naquela mesma sessão, enquanto Pablo toca o apito marcando a pulsação da canção, William sopra a flauta imitando ritmicamente a prosódia dos versos cantados.

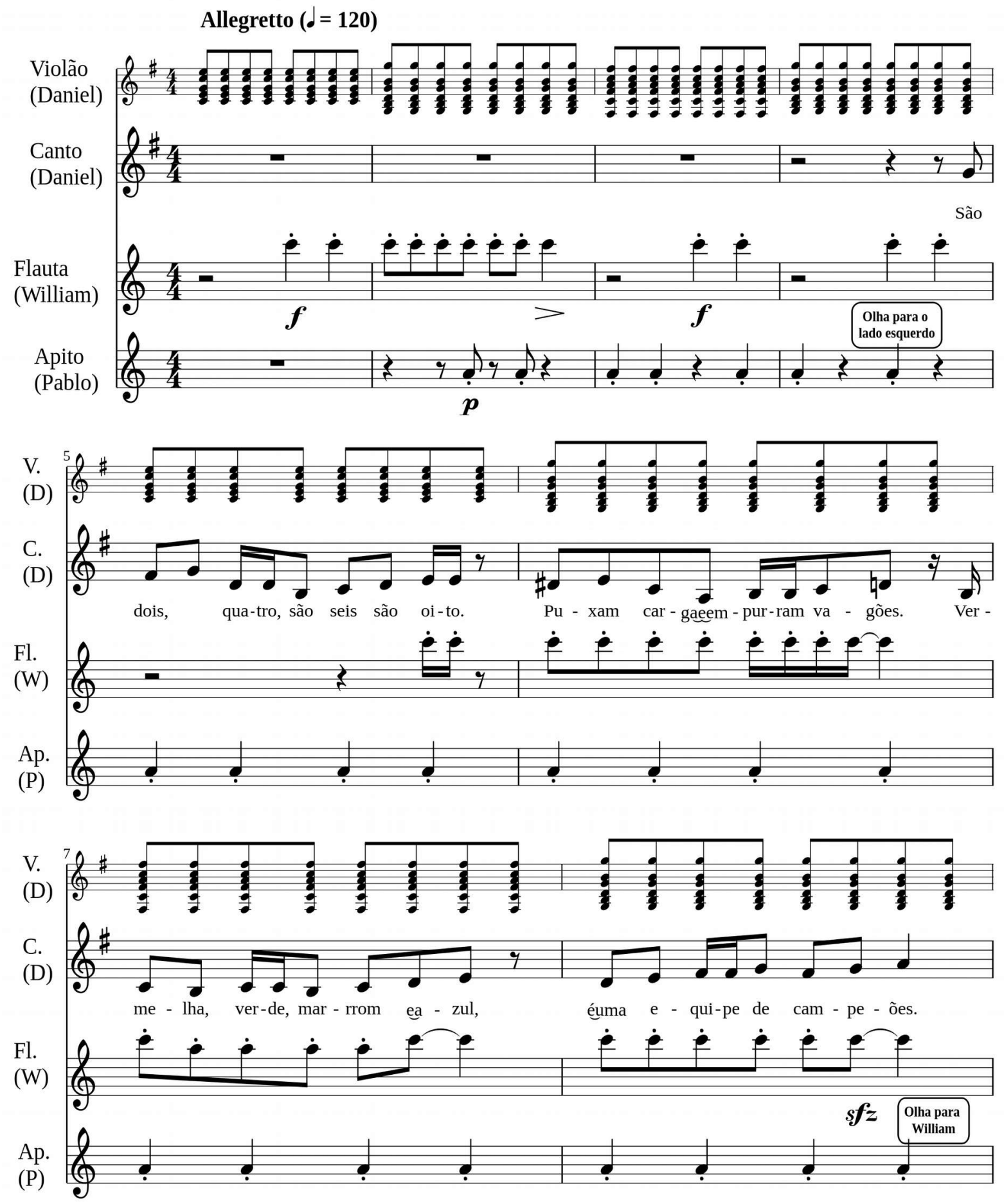




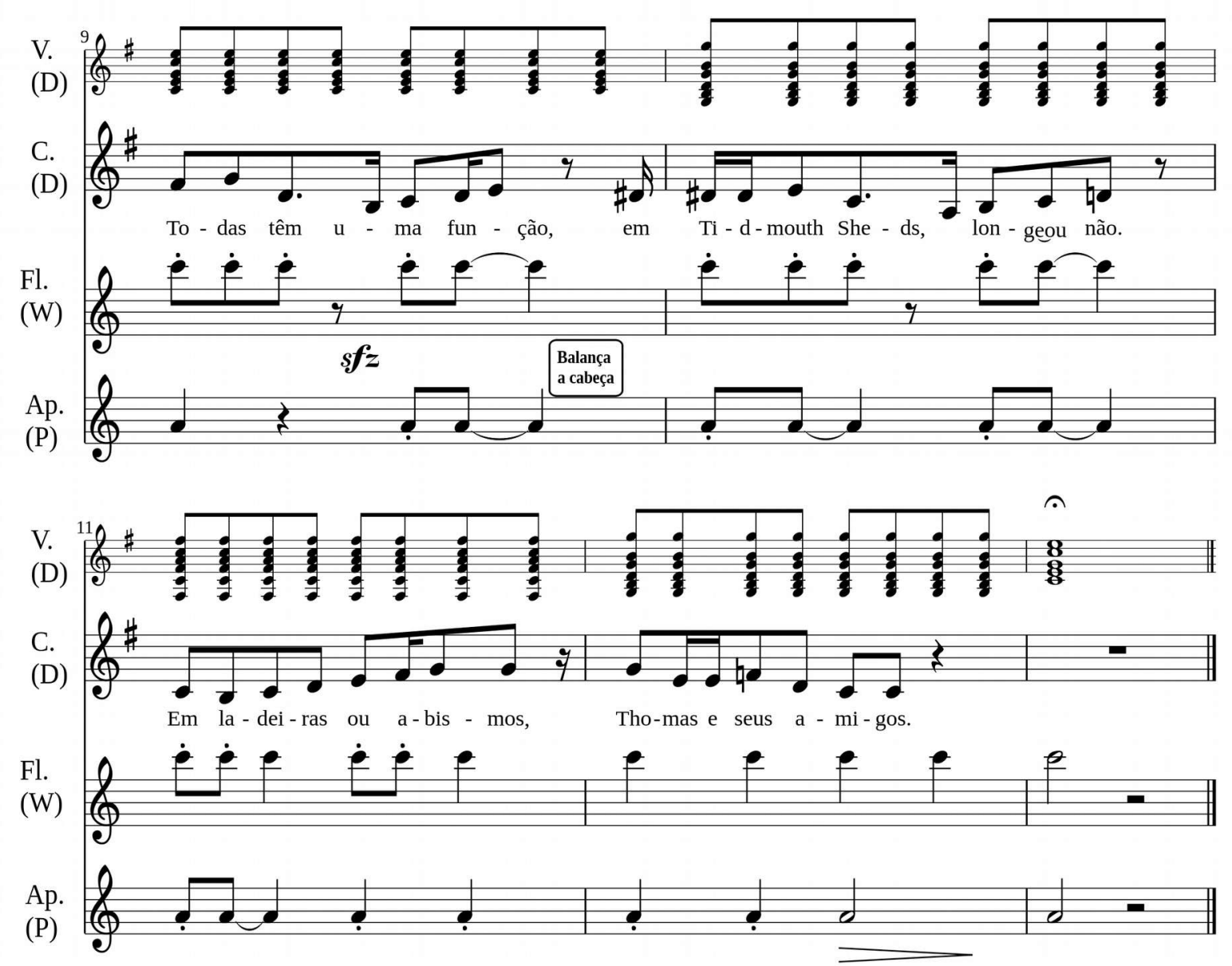

Figura 10 - Transcrição da recriação da canção “Thomas e seus amigos” na oficina de música de 06/07/13

Com relação à agitação de William, ela às vezes oferece um perigo à sua integridade e à dos demais. Isso ocorre desde os nossos primeiros encontros. Na sessão do dia 24/05, por exemplo, acontecem algumas cenas em que ele golpeia o pandeiro contra sua própria cabeça e joga os instrumentos para cima, sempre com sorrisos ou dando risadas. Apesar das intervenções e repreensões dos adultos, é impossível evitar que isso ocorra enquanto ele está na sala. As outras crianças têm reações distintas a esse modo de agir. Mathias, por exemplo, também joga o xilofone para o alto. Já Sofia, ao ser acertada por um chocalho jogado para cima, imediatamente se levanta e sai da sala. Pergunto a William se ele entendeu o motivo pelo qual ela havia ido embora e peço para que ele veja como ela, que ficou na soleira da porta do lado de fora, havia ficado zangada e que talvez ele a tivesse machucado. Digo também que seria uma boa ideia pedir desculpas quando ela voltasse. Ele rapidamente muda a expressão no rosto e o sorriso dá lugar a um beiço, apertando o lábio superior sobre o inferior, que é projetado para fora. Ele parece estar prestes a chorar, quando digo "Pode ser? Olha aqui pra mim. Vamos pedir desculpas para ela?". Ele olha para baixo e toca as cordas do violão que tenho no colo e diz "Vamos", en- 
colhido e com uma voz baixa, mas buscando as tarraxas do violão e girando-as. Não parece haver conexão entre a aparente consciência de haver causado um dano no outro, o compromisso com um pedido de desculpas e o comportamento de buscar o instrumento e desafiná-lo. A situação transmite para mim a ideia de que ele deseja se livrar daquele incômodo e seguir com seus movimento e sua exploração dos sons.

De fato, quando Beatriz volta e diz que Sofia gostaria de ficar um tempo sozinha, ele já está empilhando os instrumentos, como se não houvesse acontecido nada, ou estivesse liberado de pedir desculpas. Porém, eu insisto no tema, e digo que era uma pena que Sofia não pudesse participar da oficina e que nós precisávamos cuidar dos instrumentos e dos amigos, sem machucar e sem quebrar. Enquanto digo isso, William abandona a pilha de instrumentos e volta a se encolher, apoiando a cabeça sobre o braço direito e parecendo chorar. Guilherme entra na conversa e diz: "Mas William, é só ir lá e pedir desculpas", mas William abraça um tambor com os dois braços e se encolhe sobre ele. Beatriz diz então que tinha uma sugestão: "Acho que podemos tocar uma música e depois tentar mais uma vez [pedir desculpas] com ela”. Isso faz com que William automaticamente deixe o tambor rolar pelo chão e volte a reunir a sua pilha. Quando estamos falando sobre as consequências da sua ação, ele se encolhe. Porém quando propomos outra coisa, como tocar uma canção, ele rapidamente volta ao que estava fazendo, como se nada houvesse ocorrido.

Fica claro para mim que o grupo se encontra diante de um impasse: a dificuldade de William em permitir a entrada do outro em suas brincadeiras e sua recusa em participar das propostas que não sejam aquilo que ele quer. Parece que ou ele coordena a atividade ou brinca sozinho, fora do grupo. Essa exclusão é desestruturante para a oficina, pois ele frequentemente chama ou desvia a atenção dos demais, faz com que um adulto saia da roda para acalmá-lo ou corrigir algo que ele faz (abrir a torneira, jogar coisas para o alto, etc), ou agarra as outras crianças, machucando-as. A imagem da confusão é o que ele nos conta de si, como na imagem de um livro infantil que ele nos mostra na sessão do dia 04/10/13, na qual uma casa explode e suas partes voam pelos ares (Fig. 11).

Esse comportamento faz com que a equipe se esforce em garantir que, ao mesmo tempo em que as propostas de William sejam atendidas, que as demais crianças também sejam incluídas. Ao mesmo tempo, não parece ser possível que ele permaneça fora, seja da atividade, ou da sala, pois sua presença atravessa o grupo e sua ausência é uma falta para as demais crianças, que já demonstravam ter uma interação positiva com ele. 


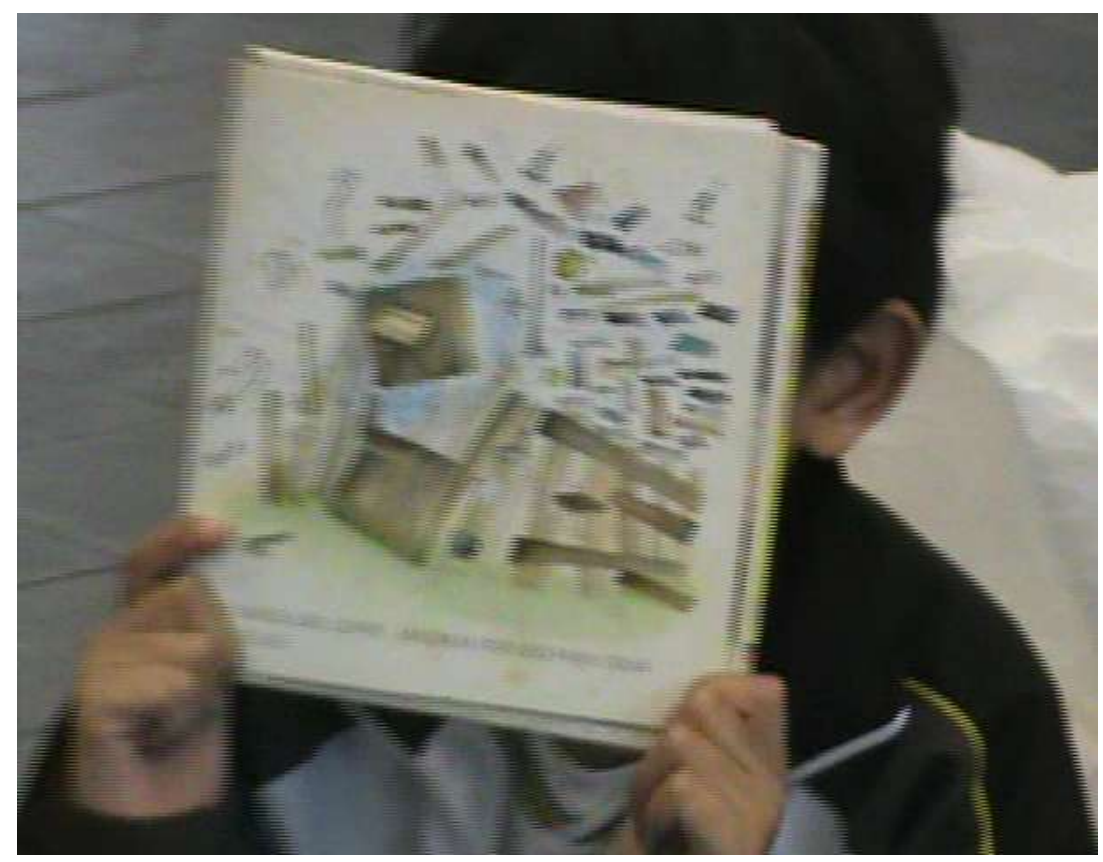

Figura 11 - Fotograma da sessão de 04/10/13

A direção de tratamento é que William possa modular sua relação com os outros e possa compartilhar o que deseja fazer e permitir que os demais atuem. Às vezes é ele mesmo quem toma essa iniciativa, como em um um pedido seu por uma "Música assustadora" (Fig. 12). Tratase de uma improvisação que começa logo após William levantar-se e apagar a luz. Após voltar para a roda, ele se senta com o olhar fixo em algo à sua frente. Ele ergue o chocalho à altura da cabeça, agitando-o suavemente, mas sem um ritmo marcado, aparentemente aproximando-o do ouvido. Guilherme, ao lado de William, e Thales, com a câmara e fora da roda, quase falam ao mesmo tempo: "Mas, William, como é que canta [essa música assustadora]?" e "Então você tem que cantar, William”. Ele imediatamente abaixa o chocalho ao chão, vira sua cabeça à esquerda, em direção a Guilherme, e aí ouvimos o primeiro "uh", que ele canta em ré. Ele é quase imperceptível - de tão suave que é pronunciado sobre as notas fortes de Pablo sobre o xilofone, que vai em um glissando de um lado para o outro, e a voz do adulto que tenta contê-lo dizendo que aquele instrumento entraria em seu momento - mas talvez tenha sido a sua duração de quase 4 segundos que atraiu a minha atenção e a de Guilherme. Quase em continuidade com aquela nota, começamos a repeti-la em dueto. Isso provoca um sorriso em William, que nos pergunta se íamos cantar a música assustadora. A sua voz é fraca e sussurrada, e peço a ele que nos ensine como ele gostaria que ela fosse. O chocalho, que ele agita cuidadosamente, marca uma pulsação livre, com pausas prolongadas e espaços de tempo diferentes entre cada movimento do instrumento, e sua intensidade é igualmente fraca. Essa marcação consolida um andamento lento mas 


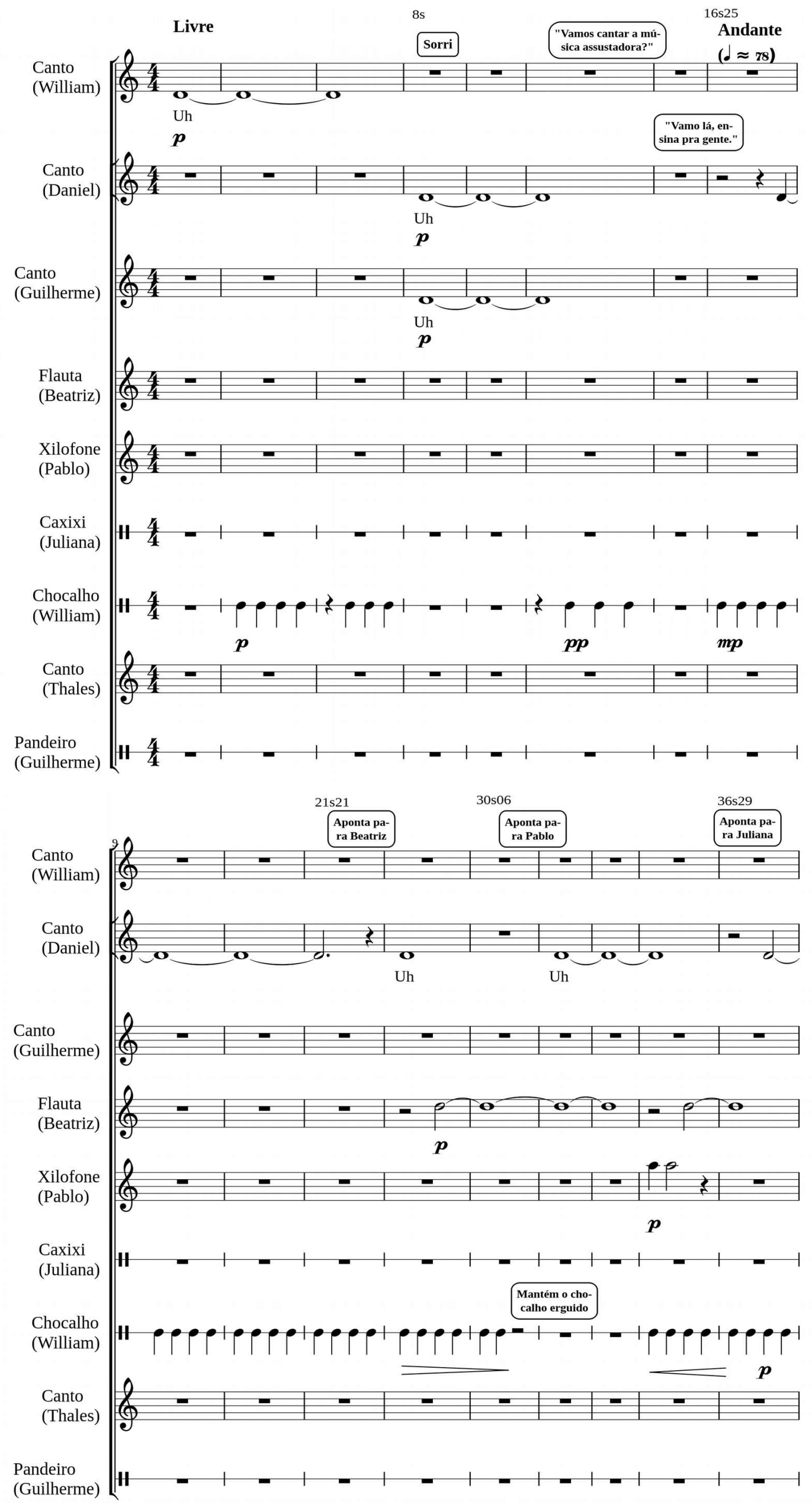




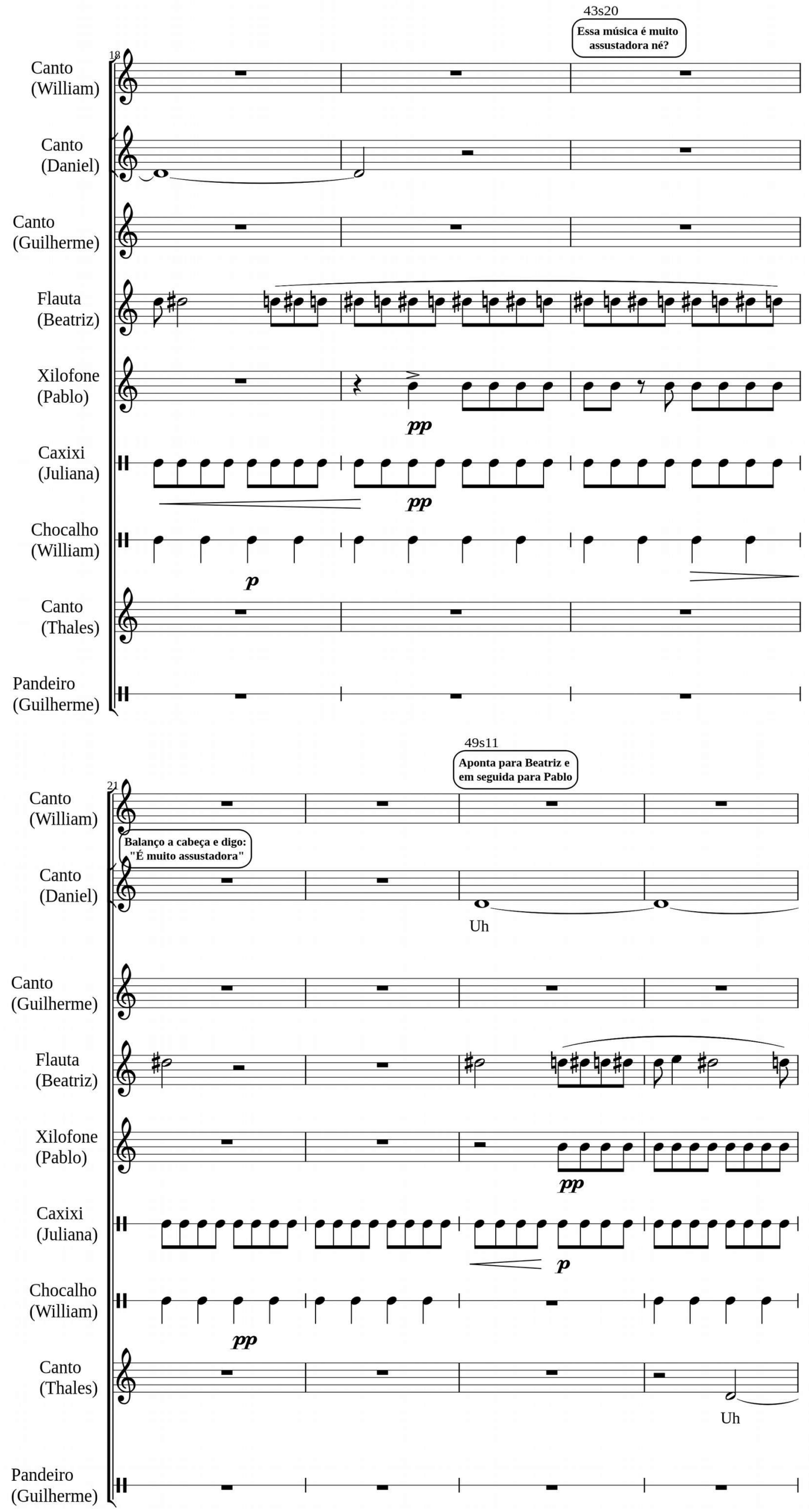




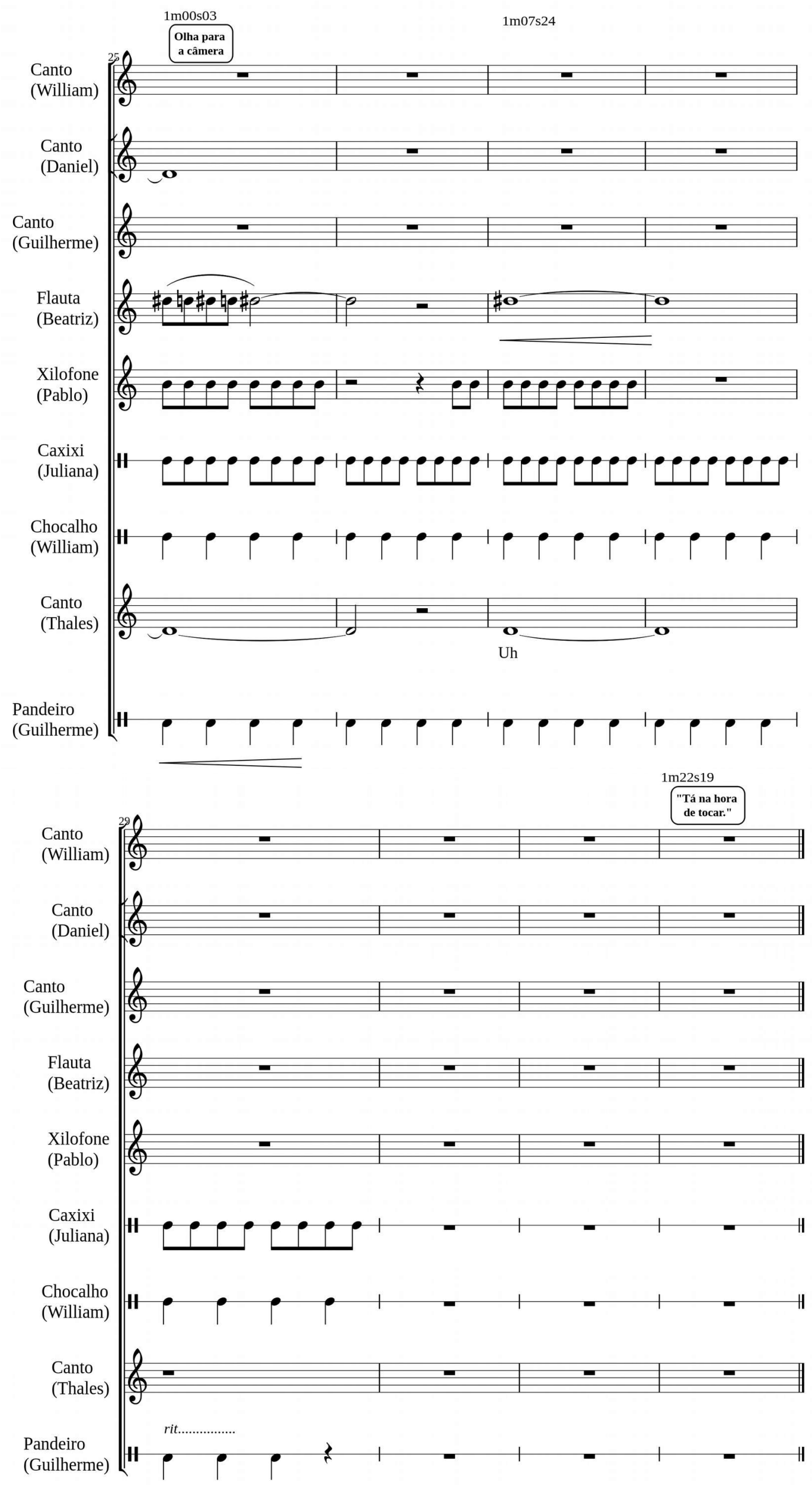

Figura 12 - Transcrição da improvisação "Música Assustadora" na oficina de música de 06/07/13 
tenso, que será constante ao longo da improvisação e formará o fundo no qual os demais instrumentos vão sucessivamente entrando e saindo conforme a sua ordem.

A marcação do pulso é, apesar de sua constante, muito sutil, diminuindo de intensidade em alguns momentos. E após um andamento mais definido ser assumido, há um movimento crescente de intensidade, acompanhado pelo incremento da polifonia. À voz, soma-se a flauta - que, com precisão, duplica o ré uma oitava acima -, seguida do xilofone e do caxixi. Uma inflexão marca o fim do $20^{\circ}$ compasso, quando William se demonstra satisfeito com o resultado, dizendo que aquela música era muito assustadora, o qual consinto acenando com a cabeça. Entramos em um novo movimento crescente quando ele indica que os instrumentos sejam retomados, aos quais se juntam Thales, que está gravando - e cujo canto chama a atenção de William -, e o pandeiro de Guilherme, que confere uma intensidade ainda maior ao conjunto e reforça a marcação da pulsação dada por William, conduzindo a uma resolução em ritardando.

A voz e o as notas suaves do instrumento, a posição em segundo plano e a concentração e sensibilidade aos gestos e ações do outro são definitivamente contrárias ao que William nos proporciona no resto do tempo que passa conosco. Diferente do usual, aquela improvisação parece ser um momento de segurança e harmonia para ele, onde lhe é possível exercer sua presença e até mesmo fazer com que todos acompanhem as suas instruções, em uma estrutura improvisada mas organizada coletivamente, sem a necessidade de barramentos externos ou repreendas. $\mathrm{O}$ resultado é um dos momentos de maior entrega a uma experiência compartilhada que tivemos como grupo, e a demonstração de que existem outras qualidades possíveis no laço social entre William e os demais.

É também uma das poucas oportunidades em que, após tocar uma improvisação ou canção, o grupo faz uma pausa em silêncio. Ao contrário do que seria mais usual, isto é, que alguém diga algo, movimente-se ou toque um instrumento ao final da peça, dessa vez todos permaneceram imóveis, como que mantendo uma tensão e suspense no ar, claramente adequada ao que seria uma canção assustadora. Durante esse poucos segundos, ocorre uma troca de olhares e expressões faciais, e a experiência que compartilhamos se estende pela zona do silêncio. É algo similar ao que vamos no final da execução de uma peça por músicos profissionais, segundos antes do aplauso da plateia. Um momento presente que não é mais a peça, nem aquilo que vem depois dela. Posso perceber uma tensão crescente naquele instante, mas aos poucos surgem a consciência e a lembrança de que aquela improvisação havia sido especial. É um silêncio que, no entanto, parece ser insuportável para William, que o interrompe com um sonoro 
“É hora de tocar!". Há uma risada em conjunto, que talvez afrouxe a tensão que a "Música assustadora" nos havia provocado.

O comportamento agitado e desajeitado de William nos faz pensar, pra além dos efeitos dinamogênicos da música, na existência de alguma falha na constituição da sua imagem corporal. Como se as diferentes partes do seu corpo - e dos demais corpos também - não configu rassem uma unidade, mas estivessem conectadas em uma espécie de delírio motor (JERUSALINSKY, 1996). É o que vemos quando ele, após uma piada, cai no chão e diz que é a barriga que está rindo e que ele não sabe como fazê-la parar. A isso podemos juntar também uma ocasião em que ele pede a câmera para filmar a oficina em 14/06/13. Entre algumas imagens em que apareço de corpo inteiro tocando o violão, as demais são closes em que ele enquadra partes do corpo dos demais participantes, aos quais avisa "Tô filmando seu cabelo", "Tô filmando sua boca", "Tô filmando seus olhos". Aparecem movimentos de aumentar e reduzir o zoom da câmera, aproximando-se e distanciando-se de uma letra do tapete. Depois, de uma bola de algodão amarrada à flauta de pã, de seu próprio dedo sobre a lente e assim em diante. Esse domínio das possibilidades do equipamento, bem como os momentos em que eu apareço inteiro no quadro, reduz a probabilidade de que as imagens sejam acidentais ou não-intencionais. A impressão que se tem ao assistir o resultado é que não estão presentes os outros, mas suas partes, e que estas se organizam em outras séries, nas quais as partes deixam de pertencer a um corpo específico e podem ser combinadas em um outro conjunto, que ele desloca de um lado para o outro por meio da câmera.

Essa multiplicidade desunida nos fez pensar também na quantidade de timbres de vozes diferentes que William parece ser capaz de empregar em seu discurso. Em diversas situações, ouvimos uma voz que não parece ser a sua, mas sim extraída de um programa de televisão. Isso fica mais evidente quando o ouvimos imitar de fato as aberturas dos desenhos animados, as vinhetas dos canais infantis ou falas que identificamos como sendo de algum personagem. Essas qualidades sonoras, no entanto, se repetem também em momentos no quais ele parece mais excitado, tomado por algum afeto de alegria ou surpresa. Nesses casos, o conteúdo da sua fala parece ser próprio, mas a forma não. A seguir, a análise espectral e acústica de uma vocalização sua nessa mesma oficina de 14/06/13 é apresentada como um exemplo dessa "outra voz", que William parece empregar em determinadas situações (Fig. 13). Após a gravação com a câmera descrita anteriormente, Thales pede que ele lhe entregue a câmera e se junte à roda. Há uma excitação motora que podemos perceber no modo como a câmera treme, e William parece es- 
tar emocionalmente tomado pelo ato de gravar o grupo. Ele rejeita o pedido de Thales, mandando-o ir procurar um instrumento e tocar. Há uma diferença na qualidade vocal empregada nesse momento que é facilmente perceptível. A voz se torna rouca e grave, como se estivesse sendo produzida no fundo da garganta, mas também com pouca ressonância, parecendo que William comprime os maxilares e os dentes ao falar.

A análise espectral confirma a impressão subjetiva das qualidades vocais dessa vocalização. Primeiramente, há uma faixa intensa de harmônicos graves, o que confere à voz o aspecto gutural e rouco. Podemos ver como ela se alterna com a linha de pitch mais aguda, indicando que esse componente mais grave assume por alguns momentos o componente espectral fundamental e constitui a nota que de fato escutamos. Apesar dessa instabilidade harmônica, o contorno melódico principal apresenta uma variação mínima, com picos prosódicos pouco acentuados e praticamente lineares. Uma variação reduzida das alturas confere o caráter monótono da vocalização, associada à ideia de que ele comprime os maxilares e os dentes enquanto a enuncia.
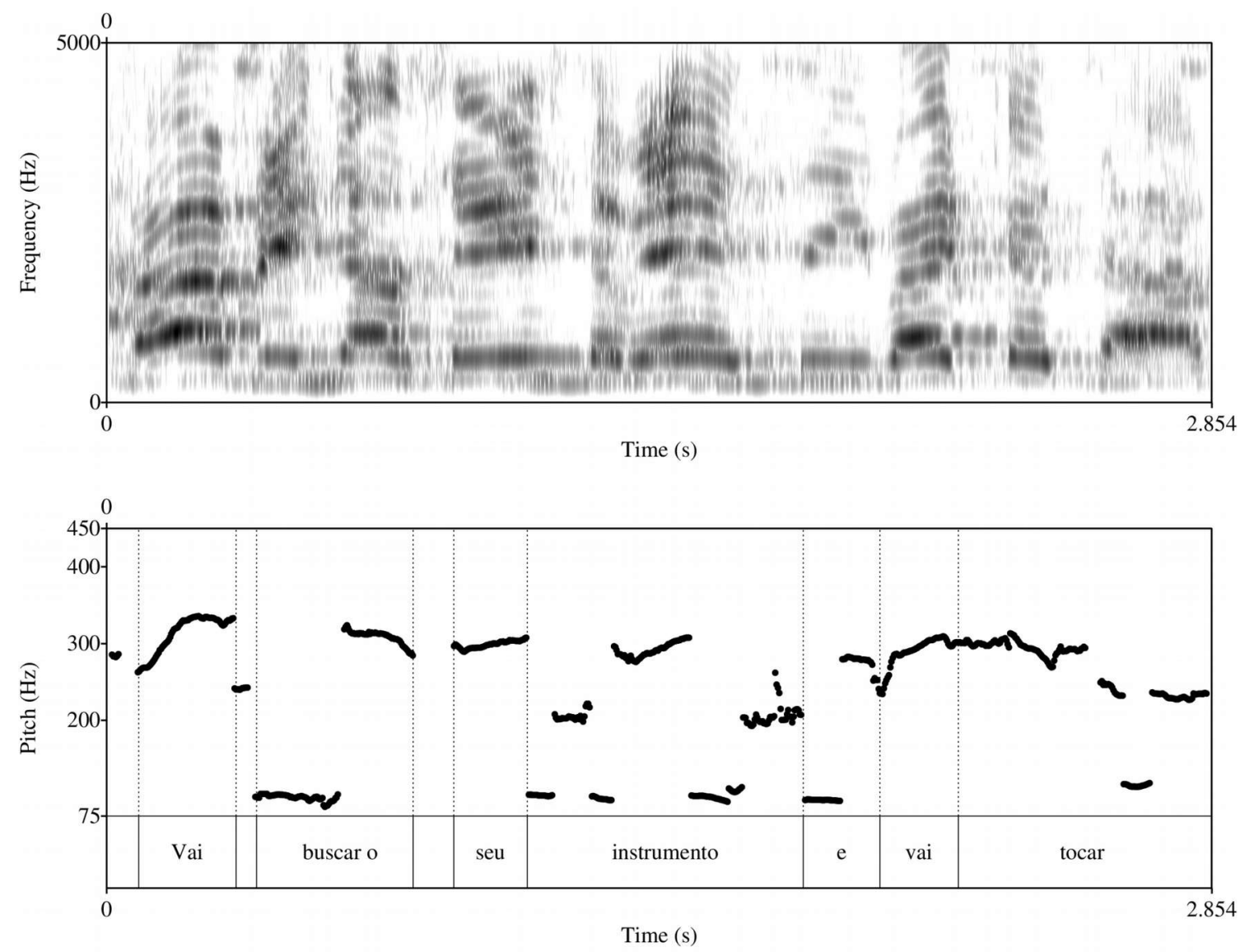

Figura 13 - Análise espectral e de pitch de uma vocalização de William na oficina de música de 14/06/13 
Diríamos também que ela expressa uma qualidade emocional equivalente, pois confere ao enunciado um tom mais imperativo, talvez com a intenção de aumentar sua eficácia enquanto ordem. Porém, o mais importante seria ressaltar que essa qualidade vocal surge frequentemente nas sessões da oficina, em situações variadas e nas quais pode ser evidente ou não que ele está encenando a fala de um outro personagem. Isso torna difícil estabelecer o seu sentido, porém é possível notar que ela geralmente acompanha um estado de excitação, por um motivo qualquer. No final, a voz representa mais um elemento indicador da experiência subjetiva fragmentada que acreditamos ser a de William.

Nos perguntamos sobre como a música pode oferecer a ele uma possibilidade de retomar a construção de uma unidade a partir desses diversos fragmentos. Será possível que ela apresente um poder organizador a partir do qual ele estabelecesse nexos entre as partes e o todo? Isso parece ocorrer em sua evolução nos jogos de alternância, sobretudo nas canções de abertura e encerramento da oficina, nas quais ele parece estar desenvolvendo a habilidade de aguardar a sua vez, respeitando as dos demais, e principalmente aproveitando-a para encontrar seu lugar em uma estrutura que acomode cada elemento em um todo com o mesmo sentido. Nessas situações, sentado na roda com o resto do grupo, ele não mostra tantos sinais de uma excitação motora excessiva como nos momentos em que está de pé ou correndo pela sala.

Uma das discussões que frequentemente surge nas reuniões da equipe clínica é o modo de refrear essa agitação quando ela aparece. É o resultado da compreensão de que é necessário incidir de alguma forma no modo como William se comporta, que tanto enfraquece o seu vínculo com os demais quanto desorganiza o grupo, mas também de um questionamento da eficácia de contê-lo verbalmente ou mesmo repreendê-lo. Em geral, ele rapidamente descumpre os combinados ou finge que nada lhe está sendo dito, repetindo o que quer que esteja fazendo. Ao mesmo tempo, há uma necessidade por parte de todos os adultos em estar atentos para evitar que ele agrida as demais crianças ou quebre um instrumento, ou que alguém adote uma postura mais firme e dura com ele. Em todos os casos, é uma tarefa que exige esforços redobrados de toda a equipe.

$\mathrm{Na}$ reunião do dia 04/10/13, convidamos a acompanhante terapêutica que trabalha com William na escola. Trata-se de uma estudante da graduação que exerce essa atividade como um estágio no núcleo. $\mathrm{O}$ acompanhamento terapêutico não foi um pedido da escola, mas uma proposta do grupo, o que gerou um certo desconforto na instituição educativa. Provavelmente, a sua presença despertou ansiedades persecutórias na direção da escola, que dificultava a inser- 
ção da aluna na classe, sugerindo que ela acompanhasse William por meio de câmeras instaladas nas salas, a partir de um local de monitoramento. Ela nos conta que a conduta de William na escola é muito próxima àquela que ele apresenta no grupo terapêutico. Lá ele também joga as coisas para cima com frequência, mas ela acredita que isso seja um reflexo de uma brincadeira com bola da qual todas as crianças participam no recreio da escola. Sem ordem ou time, elas apenas jogam a bola para o alto, repetidas vezes, e correm para ver quem a pega primeiro. Ali, William também agride as crianças, esbarrando nelas ou empurrando-as, e sofre o seu rechaço. Os companheiros têm medo dele ou o reprimem, e se defendem sozinhos ou pedindo ajuda aos adultos. É comum que as crianças levem brinquedos, mas William os joga no chão ou destrói as montagens dos outros, e faz com que a direção da escola suponha que a intenção dele é magoar os colegas. É aí que nossa intervenção difere daquela da instituição educativa, pois a resposta dos professores é segurá-lo, gritar com ele e levá-lo à força até a criança agredida, fazendo com que ele se desculpe.

Uma das intervenções empregadas por nós para agir nessa dimensão é o estabelecimento de regras de tocar (WIGRAM, 2004) que organizem de alguma forma as atividades da oficina. Um exemplo bastante útil são os jogos musicais de alternância, em que cada um tem o seu momento para dizer ou encenar algo, convocado por um verso ou figura musical que faz a passagem de um participante ao outro. Seria o caso da canção de abertura e encerramento da oficina, mas também das diversas adaptações da segunda parte de "Ciranda, cirandinha”. Outra regra de tocar que serviu como intervenção terapêutica no trabalho com William foi a alternância de intensidades, em que o grupo todo executava partes em forte e fraco. Algumas vezes, pude introduzir essa alternância dizendo "agora, a próxima parte, bem baixinho", outras vezes apenas indicando com um gesto facial expressivo, ou um movimento de me ajoelhar quando estava de de pé, seguido da apresentação da nova dinâmica. No segmento analisado espectralmente abaixo, correspondendo à sessão de 21/06/13, podemos acompanhar um trecho da apresentação da canção "Cocoricó” em que as duas intervenções são seguidas uma da outra (Fig. 14).

A canção havia sido solicitada por William, imediatamente após terminarmos a canção de abertura da oficina. Ele não tapa nenhum furo da flauta doce e a sopra com força, produzindo harmônicos altíssimos e intensos. No gráfico espectral e de pitch, selecionamos a faixa de frequências mais alta, onde é possível acompanhar esses harmônicos quase que separados dos demais instrumentos (violão, xilofone, tambor, pandeiro e flauta de pã). As notas da flauta 
doce produzem uma massa sonora que preenche o espectro com uma textura de intensidades, mas é possível perceber um padrão de quatro notas curtas e uma longa, que possivelmente cor responde ao ritmo do verso "Co-co-co-ri, hiii” repetido no refrão, reforçando a hipótese de que os sons instrumentais adquirem valor de fala para William. Antes do final do refrão, anuncio que faremos uma redução da dinâmica no próximo verso, o que provoca uma caída na intensidade. Todos tocam mais fraco e William permanece sem soprar a flauta por alguns instantes. Quando o faz, surgem notas curtas e hesitantes, que adquirem a cada nota um contorno melódico decrescente mais claro. Isso me faz pensar que ele não encontra naquele excesso o mesmo efeito que extraía das notas altas e fortes em meio a uma confusão de sons também fortes. Frente a esse fundo sutil, as notas agudas se destacam de outra maneira, dado que o contraste é muito maior. Grosseiramente falando, elas perdem o sentido, pois não combinam com o novo panorama dinâmico. Mesmo assim, William insiste e solta uma nota longa e forte. Imediatamente diminuo a intensidade das batidas no violão, o que é acompanhado pelo resto do grupo. Há um posterior retorno ao nível de intensidade com o qual havíamos começado o verso, mas a estratégia de diminuir o som a cada nota forte da flauta é repetida, reduzindo a intensidade a níveis ainda menores. Esse jogo de respostas reforça a dinâmica mais fraca daquela parte e torna mais explícita a transgressão de William, o que parece incomodá-lo a ponto de dizer "Assim não tá melhor”, enunciado marcado com um X no gráfico.

O mais interessante não é que a intervenção incida no excesso e transbordamento de William - o que é indicado pela redução da quantidade de notas altas e fortes -, mas que ela termine por conferir-lhes um outro sentido dentro do conjunto. Em lugar de criar uma textura de harmônicos altíssimos, essas notas agora marcam a passagem para o último refrão e o desfecho da peça. A regra de tocar, portanto, atua definindo zonas temporais de adequação e transgressão para determinados instrumentos e modos de tocar, nas quais William pode por à prova sua conduta musical sob o prejuízo da qualidade estética do resultado final. Não há um juízo moral, e nem mesmo uma advertência oral, que o impeça de tocar de determinada maneira. É simplesmente a falta de harmonia da sua ação com a estrutura musical daquele momento que o faz perceber que a música "não está melhor" quando notas altas e fortes se sobrepõem a um acompanhamento sutil.

Apesar de a experiência do jogo de alternâncias ter sido um dos momentos em que William podia se afinar com o restante do grupo, os instrumentos cada vez mais se destacavam como objetos que dificultavam o trabalho clínico com ele. A cada sessão, havia diversos mo- 


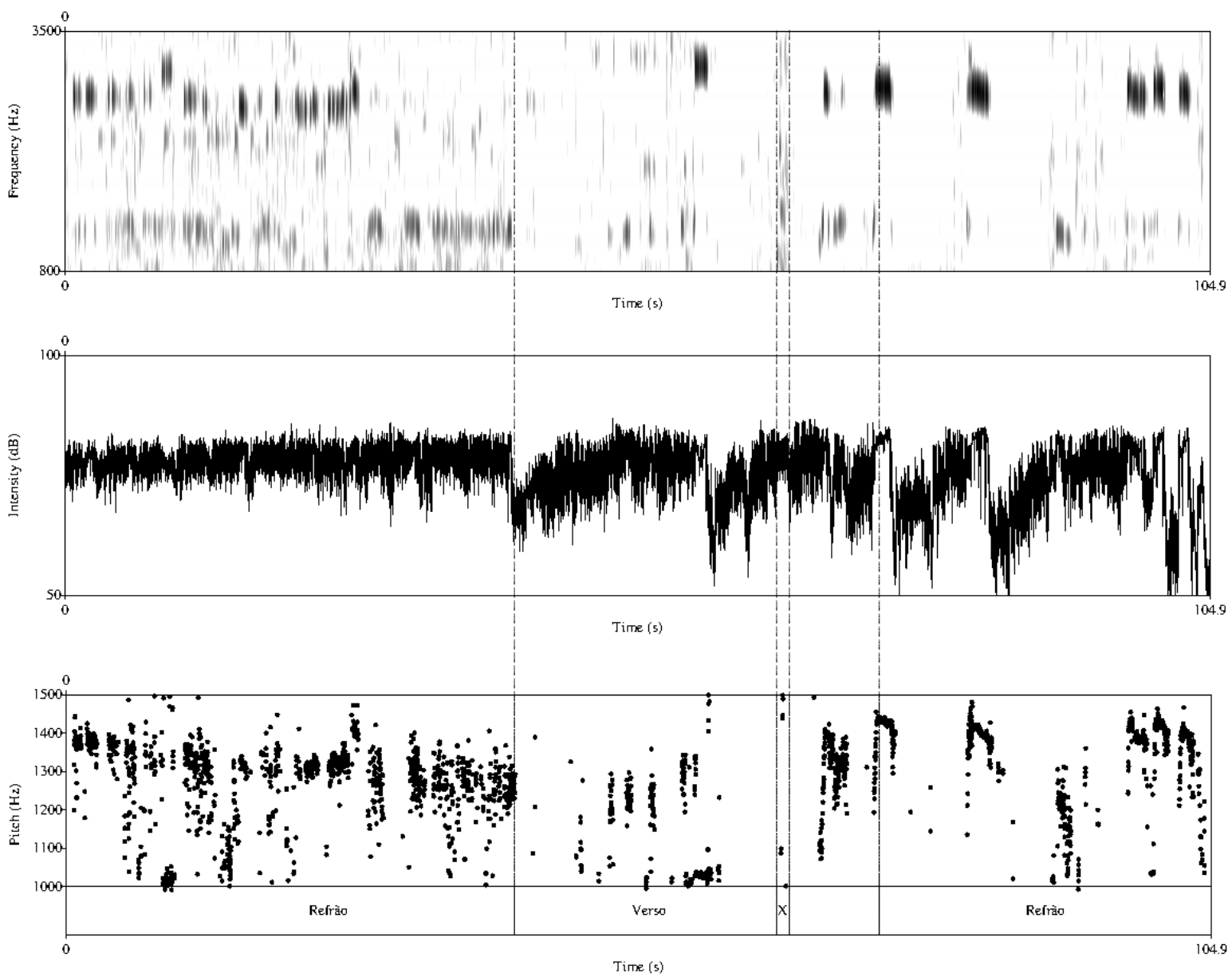

Figura 14 - Análise espectral, de intensidade e de pitch de trecho da canção "Cocoricó na oficina de música de $21 / 06 / 13$

mentos em que ele se engajava em um uso dos objetos que, ao mesmo tempo, tomava-o por completo e geralmente conduzia àquele padrão mais ou menos esboçado de agitação e agressividade. A flauta doce, por exemplo, era o instrumento mais usado. Mas ele só podia tocá-la de uma única maneira, soprando-a sem tapar nenhum furo, como se fosse um apito. Apesar das tentativas de explicar-lhe como extrair mais sons usando os dedos e controlando a força do sopro, o som agudíssimo e forte era o que ele mais produzia com aquele instrumento. Isso dificultava as atividades da oficina e implicava pelo menos dois revezes ao grupo. Primeiramente, aquele modo de tocar praticamente anulava a sua relação conosco e dificultava que cada um pudesse escutar o outro, às vezes produzindo uma desorganização nas outras crianças, que podiam começar a gritar e a atirar os instrumentos para o alto. Além disso, outras crianças ficavam muitas vezes privadas de tocar também aquele instrumento. Isso representava um problema no trabalho clínico com os demais, especialmente com Camila, que havia tido um contato 
interessante soprando a flauta doce. É aí que inventamos a regra de alternar os instrumentos, trocando-os entre todos ao final de cada canção. A novidade foi recebida com desgosto por William, que não queria trocar a flauta com ninguém, mas foi progressivamente sendo aceita. Mesmo assim, ele aceitava somente trocar a flauta por pouco tempo, recuperando-a ao fim da música ou mesmo antes dela terminar, agarrando-a de seu companheiro.

Foi preciso então uma revisão dos instrumentos que eram levados à oficina. A flauta doce foi separada a partir da sessão de 16/08/13, muitas vezes sendo entregue diretamente a Camila como uma tentativa de convite à oficina ou para que ela pudesse tocar algum instrumento, mesmo que estivesse fora da sala. Naquela sessão, William abre a bolsa e, ao não encontrar o instrumento, diz com uma voz bastante expressiva de seu desapontamento, "Eu queria tocar a flauta-tambor”. Apesar de não estar de acordo com a nova regra, essa reorganização dos instrumentos vai terminar por ter um impacto na maneira como ele lida com esses objetos e uma abertura a outro modo de relação com o outro.

Com relação à quantidade, passei a levar apenas um instrumento por pessoa. Isso permitiu escolher uma variedade de combinações antes de começar cada sessão. Os instrumentos com menor potência sonora se mostraram facilitadores da comunicação e interação entre os membros do grupo. Do conjunto de apitos, passamos a usar apenas os mais graves, e os tambores agora eram tocados sem as baquetas. Houve uma nítida redução do volume sonoro das sessões. Ao começar a segunda metade do período em que a oficina foi realizada, nossos encontros eram muito mais "intimistas", para comparar com a ideia das apresentações musicais em que a redução dos elementos diminui a distância entre a plateia e o músico. Em alguns momentos, as luzes eram apagadas, e em outros passávamos longos momentos deitados nos colchonetes, improvisando sobre ritmos lentos com sonoridades suaves dos instrumentos e das vozes. É claro que havia o momento da bagunça e da correria, mas ele agora era delimitado por esse outro modo que encontramos para interagir. Isso coincidiu com uma redução dos momentos de excitação de William, que também começou a fortalecer seu laço conosco, participando mais das atividades e do círculo da oficina.

Em alguns momentos em que a agitação surge na forma da brincadeira de correr ao redor do grupo, em lugar de pedir que ele se acalme e se sente, é possível dar-lhe um outro sentido, convidando todos a se levantar e dançar, incorporando seus giros em uma ciranda, por exemplo. Outros jogos simbólicos são também possíveis, como ocorre na sessão do dia 04/10/13 quando, em uma tentativa de prolongar os efeitos da recriação da canção de abertura do dese- 
nho "Thomas e seus amigos", me levanto e o agarro pelo braço quando ele passa correndo atrás de mim, e proponho brincar de locomotivas de um trem. A princípio ele se recusa a se adaptar à minha velocidade, dizendo "é hora da confusão!", correndo em disparada ao redor dos colchonetes. É apenas na volta seguinte que ele entra na brincadeira, quando peço para estacionarmos e que ele sopre um apito para avisar aos passageiros - encenados pelos outros adultos e crianças - que o trem está partindo. Aí sim a velocidade é um elemento que precisa ser considerado, pois se William corre, os demais vagões ficam para trás e a composição se desfaz. Em um certo sentido, é a brincadeira que freia a correria, e assim fazemos nosso percurso, visitando outras estações, embarcando e desembarcando passageiros, apitando e fazendo o som de engrenagens e freios, parando para abastecer e mudando o trajeto e direção.

Uma outra direção de tratamento que, portanto, se mostra adequada ao trabalho com William é o estímulo à fantasia e o faz de conta simbólico, proporcionando-lhe elementos estéticos, como canções, personagens e figurino, que possam ser incorporados às narrativas que ele traz ao grupo. Essa proposta surge da sessão do dia 13/09/13, na qual as crianças brincam, ainda no grupo da manhã, com um faz de conta sobre a ilha do Medonho. Mais tarde, descubro que de fato existe uma "ilha misteriosa" que aparece no seu atendimento individual, na qual um caminhão que está levando uma tábua para a ilha misteriosa participa de algumas das brincadeiras entre ele e Júlia. De qualquer modo, é assim que as crianças se apresentam para mim quando começa a oficina de música: William era o pirata, Pablo o piloto aviador, e Camila a rainha da ilha. Combino com William que vamos fazer a música da ilha do Medonho após a canção de abertura da oficina, o que é prontamente lembrado por ele assim que terminamos de escolher a apresentar os instrumentos. Pergunto como seria essa tal música, o que ele não parece conseguir responder. Peço alguma ideia e ele sugere a música do "Big Boy", ou algo assim, o que não conseguimos compreender. Ele então diz "Ah, eu não consigo, isso é muito difícil”. Tento tranquilizá-lo, falando que não havia problema, que iríamos fazer a música da nossa ilha do Medonho. Começamos por tocar os instrumentos e a descrever a história. Eu ocupo o lugar do narrador: "Tinha um pirata... com chapéu de caveira... Tinha também um aviador" (aponto para Pablo, fazendo o ruído do motor do avião). William diz que escutou o barulho da coruja, fazendo o canto do pássaro na flauta. "Outros pássaros" (assobios dos demais). "Aí, começou a chover" (som de chuva nos pandeiros e chocalhos). Júlia diz "Estava ventando muito... Aí, veio um raio" (Mathias dá um grito, os instrumentos aumentam o volume). "O avião atravessou a nuvem" (faço o som do avião caindo). "Parou de chover, e o aviador ficou 
sozinho na ilha do Medonho... De repente ele começou a ouvir uns passos" (William faz os passos com os cocos e depois se levanta e começa a marchar). Pergunto de quem eram esses passos e ele responde "são os meus pés". "Mas o pirata não estava sozinho, havia outras pessoas com ele" (todos fazemos passos, batendo as palmas das mãos no chão). "Então eles pararam porque encontraram uma cobra" (faço o som da língua da cobra vibrando e todos me imitam), "depois um cachorro" (o mesmo com os latidos). "Depois, eles param de novo porque eles encontraram um...", "Urso!" diz William (fazendo sons e gestos de urso). Eu complemento "E continuaram a andar... E aí eles chegaram na frente do aviador e ele viu quem eram aqueles que estavam andando... Eram os índios" (bato a mão na boca u-u-u-u e todos fazem o mesmo). Digo então que podemos cantar a música dos índios, "Um, dois, três indiozinhos....", dando continuidade à oficina.

Essa intervenção tem um efeito importante sobre William e todo o grupo. Ao mesmo tempo que o ajudamos coletivamente a concretizar seu desejo por uma música da "Ilha do Medonho", a narrativa insere a todos por completo na estrutura do faz de conta. Possivelmente, pudemos articular uma imagem que já vinha sendo trazida por ele em outros momentos de seu atendimento, porém na oficina ela ganha um desenvolvimento narrativo que a expande a outros elementos. Mais importante que isso, estes são trazidos pelo grupo, e William aceita essa contribuição em sua história. No final, há uma composição coletiva que fortalece o vínculo entre todos, além de permitir a cada um viver um universo imaginário com novos modos de ação e identificação.

Apesar de esse momento, somado a outros ao longo do tratamento, mostrar-nos que existe uma capacidade de William em abrir-se à interação com o outro e participar de uma composição coletiva, essas intervenções nem sempre dão resultado. Uma hipótese que explicasse a forma de William se relacionar com o grupo seria a de que ele deseja ser o monopólio das atenções. É o mesmo que interpretamos na atitude de Sofia de mostrar-se contrariada ou indiferente ao grupo para que este a deseje e a busque. Mas os dois diferem em suas atitudes contrárias, o primeiro pelo excesso, a segunda pela ausência. A insistência de William parece estar quase no campo das suas próprias condições de existência, como se o que estivesse em jogo para ele não fosse o fato de ser desejado ou não, mas se o seu próprio ser é que pudesse estar ameaçado na medida em que ele ocupa ou não os espaços e a direção do grupo. As intrusões do outro são sempre devastadoras, porque, ao inserir novos elementos que dão continuidade à brincadeira ou à história, estes acabam não só transformando-a como também a anulam, e as- 
sim desconstituem o mundo em que ele existia.

É o que parece ocorrer na sessão do dia 27/09/13 quando, logo no começo da canção de abertura, William apresenta uma fala de um desenho animado do Chico Bento. Pedimos para ele explique a história para que seja possível entender do que se trata, mas ele se senta com o resto do grupo e repete a fala uma vez mais. Com a ajuda de Beatriz, descobrimos que se trata de um episódio no qual o personagem caça uma onça que supostamente devorou seu primo para fazer um tapete para o seu banheiro. É possível notar que o tom da voz é semelhante àquele analisado anteriormente.

Pergunto mais sobre a história, se o Chico Bento caçaria a onça com um laço de cowboy. Ele me diz que não, que ele o faria com um pau. Pergunto então se não podemos fazer uma versão de "Atirei o pau no gato", adaptando-a para "Atirei o pau na onça”. Chego a cantar uma primeira vez, mas William diz que não é assim, que a história é outra. Guilherme lhe dirige então uma intervenção, perguntando-lhe se seria possível que ele contasse de outra forma, com outras palavras. William se retrai, abaixa a cabeça e responde muito baixinho, a ponto de termos que pedir que ele fale mais alto, “Claro!". Mas ele se levanta e repete a mesma fala novamente, fazendo os gestos corporais do personagem, como se fosse uma dança. Passo a tocar uma progressão de acordes em Mi maior, emulando a harmonia das músicas sertanejas, em um andamento andante, e pedimos que ele conte a história novamente. Aí começa uma brincadeira que durará quase 20 minutos, na qual os diálogos do desenho são apresentados por ele uma e outra vez, e são a matéria-prima para que novos personagens sejam incluídos. William parece divertir-se conforme os demais aderem à história, sobretudo quando Pablo interpreta a onça e corre em círculos atrás de William, o Chico Bento. É difícil, no entanto, sair dessa circularidade (no tempo repetitivo da história e no espaço físico da roda) e incluir outros elementos na narrativa, motivo pelo qual nossas tentativas de trazer outros bichos como o pato e o jacaré das canções "O pato pateta" e "Os indiozinhos", são ignoradas ou não são aceitas por ele. Essas tentativas parecem saturá-lo, a tal ponto em que ele sobe na mesa e começa a gritar "Gente, gente! Vocês nunca me escutam", o que é sucedido de uma sonora risada pelos adultos, que respondem que escutá-lo é o que eles mais fazem.

Nas discussões da equipe, pensamos que não estar em constante ação - ou que os outros não o acompanhem em seu desejo - parece ser a sua verdadeira preocupação e o motivo mais frequente da sua agitação. Isso dificulta que ele recolha os efeitos que sua ação produz no outro, mas o risco de não estar em primeiro plano parece ser ainda mais crucial, é como se assim 
ele estivesse a ponto de desaparecer. E nessa corrida contra o desaparecimento, só pode existir ele e sua possibilidade ou não de ocupar o centro das atenções. É uma nova hipótese, que ganha ainda mais validade após uma conversa que William mantém com Beatriz na sessão de 08/11/13. Ela uma vez mais o levava para fora da oficina, pois nada conseguia parar sua excitação e correria em volta do grupo sentado em roda. Após uma conversa em que discutem os combinados de não machucar os demais e de não jogar os instrumentos para o alto, e na qual tentam pensar uma forma para que ele possa participar das atividades do grupo, William conta a ela que tem medo que os demais o esqueçam.

Quando retornam à sala, William diz: "vocês se esqueceram de mim”, e Beatriz nos conta o que ele lhe havia dito. Comento que às vezes também tenho medo que os demais me esqueçam e que esse é um sentimento que muita gente tinha também. Isso é algo que nos aproxima ainda mais, e o tema do esquecimento é incorporado em nossas sessões. Depois, nos encontros em que um companheiro falta, tentamos lembrar qual era a sua canção favorita e a cantamos juntos, como uma forma de lembrar dele. Algumas fotos das crianças são impressas e penduradas em uma lousa móvel e nos referimos a elas quando falamos de quem não veio. Em 31/01/13, quando Sofia falta, por exemplo, William faz um carinho em sua foto. Depois, pega uma caneta, o que nos leva a pensar que ele riscaria a foto, mas ele na verdade desenha sobre ela a imagem de um coração.

O tema do esquecimento me leva a compor então uma nova sequência à canção "O pato pateta", desta vez criando um personagem "O gato folgado". Ao contrário do pato, que leva uma vida agitada, o gato é tranquilo e está mais interessado em descansar, sentar-se no sofá e comer, apesar de ter também seu momento de aventurar-se pelo telhado.

$$
\begin{gathered}
\text { O gato folgado, } \\
\text { subiu no telhado } \\
\text { ficou cansado } \\
\text { e quis descansar. } \\
\text { Pediu um carinho, } \\
\text { pro dono esquecido. } \\
\text { Lambeu o bigode, } \\
\text { parecia um bode. } \\
\text { Pulou a cadeira, } \\
\text { gritou miau! } \\
\text { Pediu mais leite, } \\
\text { pra pôr no mingau. }
\end{gathered}
$$




\section{Sentou no sofá, assistiu a novela. \\ Tantas fez o moço...}

Essa canção pessoal dirigida a William é apresentada em nossos últimos encontros, mas não houve tempo para recolher seus possíveis efeitos. É certo que ela deu continuidade à estrutura da canção original e despertou o interesse de todas as crianças. Na sessão de 29/11/13, quando William não pôde vir, ela provocou uma brincadeira de imitar os sons dos gatos que acabou em uma grande coreografia e teve uma importância especial para Mathias. Para William, por enquanto, não sei até onde ela pode ter tido qualquer incidência.

O trabalho com William teve um desenvolvimento intenso ao longo do tratamento. A oficina de música era uma atividade prazerosa para ele, e sua participação sempre foi com muita energia e entusiasmo. A riqueza de ideias que ele trouxe para as atividades do grupo é proporcional às reflexões que nossos encontros provocaram. Foi talvez apoiado nesse interesse pela música que tantas intervenções puderam ser feitas para incidir na maneira como ele se relaciona com os demais. Esse movimento coincide com um outro, que surge nas sessões do atendimento individual, ao redor do tema da destruição e da reparação daquilo que foi destruído. Ele aparece nas diversas brincadeiras com Júlia, e indica que o processo terapêutico em curso produz seus efeitos. Agora, a presença do outro e os efeitos das suas ações parecem ganhar um contorno aparentemente mais nítido. Há um caminho ainda pela frente para que ele desenvolva seus laços sociais. Mas a música nos apresentou diversas entradas seguras para que as propostas e intervenções externas the fossem suportáveis, além de demostrar que as ideias trazidas por ele podem ganhar um sentido ainda amplo quando associadas às contribuições do outro. Isso o aproxima tanto dos adultos quanto das crianças, para quem ele transmite uma imagem de vitalidade e energia. Mais do que isso, aponta um caminho possível para um lugar e uma companhia que não the sejam ameaçadores, e nem cobrem dele um esforço constante de afirmar a sua presença.

\subsection{Pablo}

Pablo é a criança mais nova do grupo, com cinco anos. Além disso, sua constituição física confirma também esse conceito: magro, de baixa estatura, postura encurvada e uma voz sem 
volume e para dentro, difícil de ser compreendida. Apesar de não ter um diagnóstico, ele é encaminhado pela escola, justamente pelas questões de linguagem - falava em espanhol e apresentava um atraso na comunicação - e uma dificuldade de se separar. A família é composta pelo avô e a avó, naturais da Argentina, e a mãe, todos vivendo juntos na mesma casa junto com o noivo atual da mãe e padrasto de Pablo. Os avós contam que a mãe teve um envolvimento conturbado com o pai de Pablo, e que ele a abandonou durante a gravidez.

[O pai biológico] vê ainda Pablo de vez em quando, mas não mantém contato regular; já aconteceu, inclusive, dele avisar Pablo que o visitaria — criando então grande expectativa na criança - mas, sem avisos ou explicações, não aparecer. Resultado: $\mathrm{Pa}$ blo ficou visivelmente frustrado, e tudo indica que não encontrou jeito de comunicar sua angústia com seus familiares, que preferem não tocar no assunto, porque assim, quem sabe, o Pablo esquece (Relato do Atendimento Individual).

O abandono provocou na mãe uma depressão que se estendeu após o parto, e que dificultou a relação com Pablo em suas etapas iniciais. Foi a avó quem assumiu os cuidados do menino junto com seu marido, o que permanece uma realidade ainda hoje, mesmo quando vemos a mãe de Pablo em uma condição aparentemente mais estável, buscando um novo relacionamento e tentando retomar seu vínculo com ele. $\mathrm{Na}$ entrevista, no entanto, ela parece ser rebaixada pelas considerações de seus pais, como uma forma de desautorização do papel de mãe. Como um exemplo, em um momento em que ela tenta impor um limite de horário para Pablo ir dormir, o avô intervém, dizendo que o menino deve dormir a hora que quiser, responsabilizando-se por ele.

Entendemos que, para Pablo, essa configuração afetiva resultou em uma confusão a respeito da estrutura familiar.

Ele costuma chamar a avó de "mãe", o avô de "pai”; a mãe ele simplesmente chama pelo nome, e a mesma coisa vale quando ele se refere ao pai biológico; o noivo atual da mãe, que ele costuma chamar pelo apelido mesmo, já testemunhei ele confundir e trocar pelo [nome do pai] (Relato do Atendimento Individual).

Em um certo sentido, não foi só o seu próprio lugar como filho e neto que se comprometeu, mas também a sua própria identidade como criança em desenvolvimento, pois seus avós o tratam como se ele fosse menor e mais frágil do que ele realmente é, referindo-se a ele como o “bebê". Não é de se estranhar, portanto, que apesar da idade, Pablo ainda precise usar fraldas em lugar de ir ao banheiro. Menos ainda que esse seja um tema frequente nas sessões de atendimento individual.

A família conta que a escola que ele frequenta a avisa que foi encontrada uma faca enrolada no agasalho em sua mochila. A justificativa de Pablo é que ela serviria para matar sua avó, pois ela o estava abandonando na escola. É assim que nos deparamos com um dos motivos 
centrais de Pablo no tratamento individual e em grupo: o medo. Medo de ser abandonado, medo de tomar a perua escolar, medo de monstros e insetos que surgem nas brincadeiras e nas músicas que tocamos e que constitui um verdadeiro leitmotiv em torno do qual muitas atividades da oficina são organizadas. É um medo que está também vinculado a uma agressividade que localizamos no episódio da faca, mas também em uma cena de seu atendimento individual quando, em uma brincadeira com bonecos, ele se transforma em um leão, que ruge e mata toda uma família, divertindo-se com isso. Para Thales, que o atende individualmente, essas fantasias são interpretadas como a expressão dos conflitos internos que a relação com a família suscita naquela criança:

De fato, talvez fosse natural que um "bicho" ficasse nervoso com um bebê que na verdade não é mais bebê, mas que tem medo de crescer e perder o amor de uma família que o acha tão "bonitinho" dessa maneira; talvez o 'bicho' tivesse também motivos para odiar essa família, que põe e não consegue tirar essa criança-bebê diante de um impasse: cresço ou não cresço? (Relato do Atendimento Individual).

Podemos encontrar essa flutuação afetiva entre medo e agressividade, por exemplo, em uma brincadeira que fizemos na sessão do dia 10/05/13.

Pablo então pediu que cantássemos uma canção dizendo a palavra 'aranha' e fazendo um gesto de subida pela parede com a mão. Thales disse que conhecia a canção e cantamos juntos "A dona aranha". Depois, William saiu da sala, no que foi acompanhado pelo Pablo. Guilherme interpretou que eles estavam buscando a aranha, brincadeira que foi acompanhada pelo Pablo bastante interessado, entre as cadeiras dentro sala (Relato do Grupo Terapêutico, 10/05/13).

A entrega de Pablo à fantasia da brincadeira é completa, de modo que quando lhe pergunto se está com medo, ele me responde que sim. Finjo ver a aranha em um canto entre as cadeiras e ele vai até lá e pisa, dizendo ter matado o inseto, o que me indica uma capacidade acentuada de fazer jogos de faz de conta e de explicar os acontecimentos nesse registro.

Os problemas de linguagem de Pablo não tardam a aparecer nas sessões. No encontro seguinte (17/05/13), ele não apenas usa uma entonação vocal apagada e retraída como também não diz o nome do instrumento, mas o seu próprio, tanto na abertura quanto no encerramento da oficina. É possível que isso seja um resquício da atividade anterior, na qual cantamos os nomes sobre uma célula rítmica, porém essas características - a qualidade vocal e a confusão com os significantes - serão comuns nos encontros posteriores. Ele frequentemente dirá o nome em lugar dos instrumentos. Em um outro exemplo, na sessão do dia 07/06/13, ele está brincando com um carrinho quando eu chego e pergunto a ele qual é o som daquele carro, ao qual ele responde "amarelo", dizendo a cor do objeto.

Outra característica da participação de Pablo na oficina de música se refere à apresenta- 
ção de canções. Nesses momentos, ele se coloca de maneira atenta e ativa, cantando junto com o grupo, pedindo suas canções favoritas e repetindo algumas das coreografias que propomos. É nítida sua concentração no movimento de sobe e desce com as mãos com o qual representamos a subida e a descida da aranha na canção "A dona aranha”. Da mesma forma, acompanhamos suas demonstrações de alegria por meio dos sorrisos e gargalhadas ao cantar a canção de abertura do programa de televisão "Cocoricó" ou Banho é bom", no qual apontamos as partes do corpo na medida em que são nomeadas pela canção.

No que diz respeito às interações sociais, Pablo demonstra facilmente engajar-se nas brincadeiras dos demais, formando rapidamente um vínculo com os adultos e as outras crianças. Esse laço possui um aspecto imitativo muito forte no início, e vemos que ele reproduz as coreografias dos adultos sem dificuldades, por exemplo na canção “A dona aranha” (Fig.15).

a)

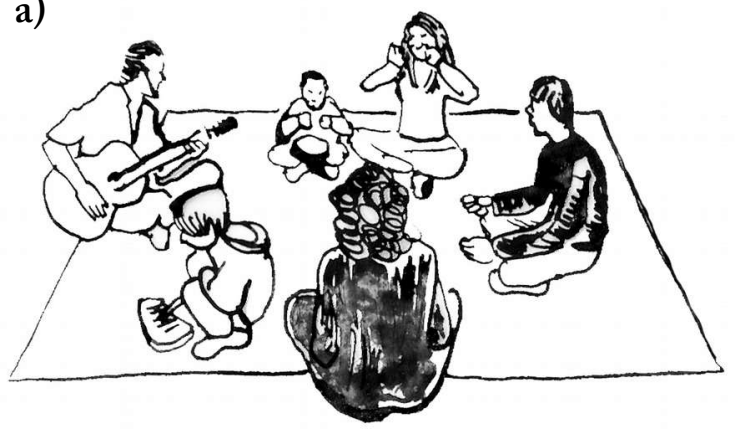

b)

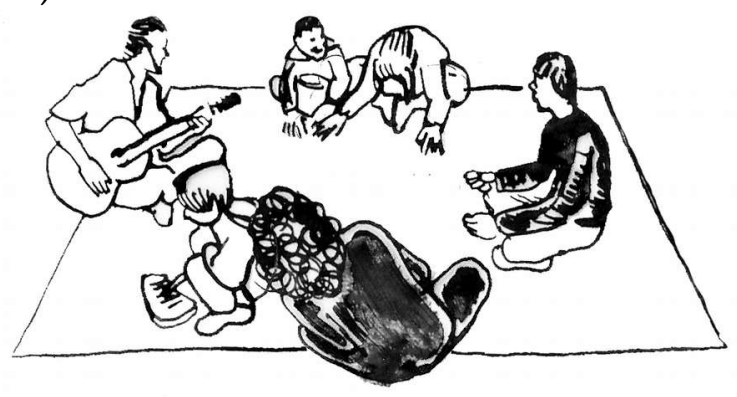

Figura 15 - Ilustração de coreografia da canção "A dona aranha" na oficina de música de 17/05/13

A cena do faz de conta com a aranha exemplifica não só a capacidade de Pablo fazer jogos simbólicos, como mostra também a relação de amizade que se estabeleceu entre ele e William ao longo desse período. Vemos os dois juntos em praticamente todos os momentos dos atendimentos em grupo, interagindo a tal ponto que, quando um dos dois falta, o que veio pergunta pelo outro e até mesmo se entristece pela sua ausência. Há algo da exuberância pulsional de William, com seus gestos agitados e desajeitados, que atrai Pablo e o faz sair da posição de retraimento e inibição. Ele está em permanente atenção ao que o companheiro está fazendo, o que muitas vezes o leva para fora da roda nos momentos em que William não está participando da atividade. São, portanto, convites explícitos e implícitos para brincar, correr e se divertir juntos. É como se William trouxesse vida para Pablo.

Provocações ocorrem também, por exemplo na sessão do dia 07/06/13. Como parte das preparações para a festa junina que planejamos fazer, proponho recriarmos a canção tradicional “Capelinha de Melão”. Começo com a batida no violão, e uma breve improvisação ocorre. 
William toca o xilofone enquanto Pablo aproxima a flauta lentamente em sua direção, com a clara intenção de incomodá-lo e chamar sua atenção (Fig. 16).
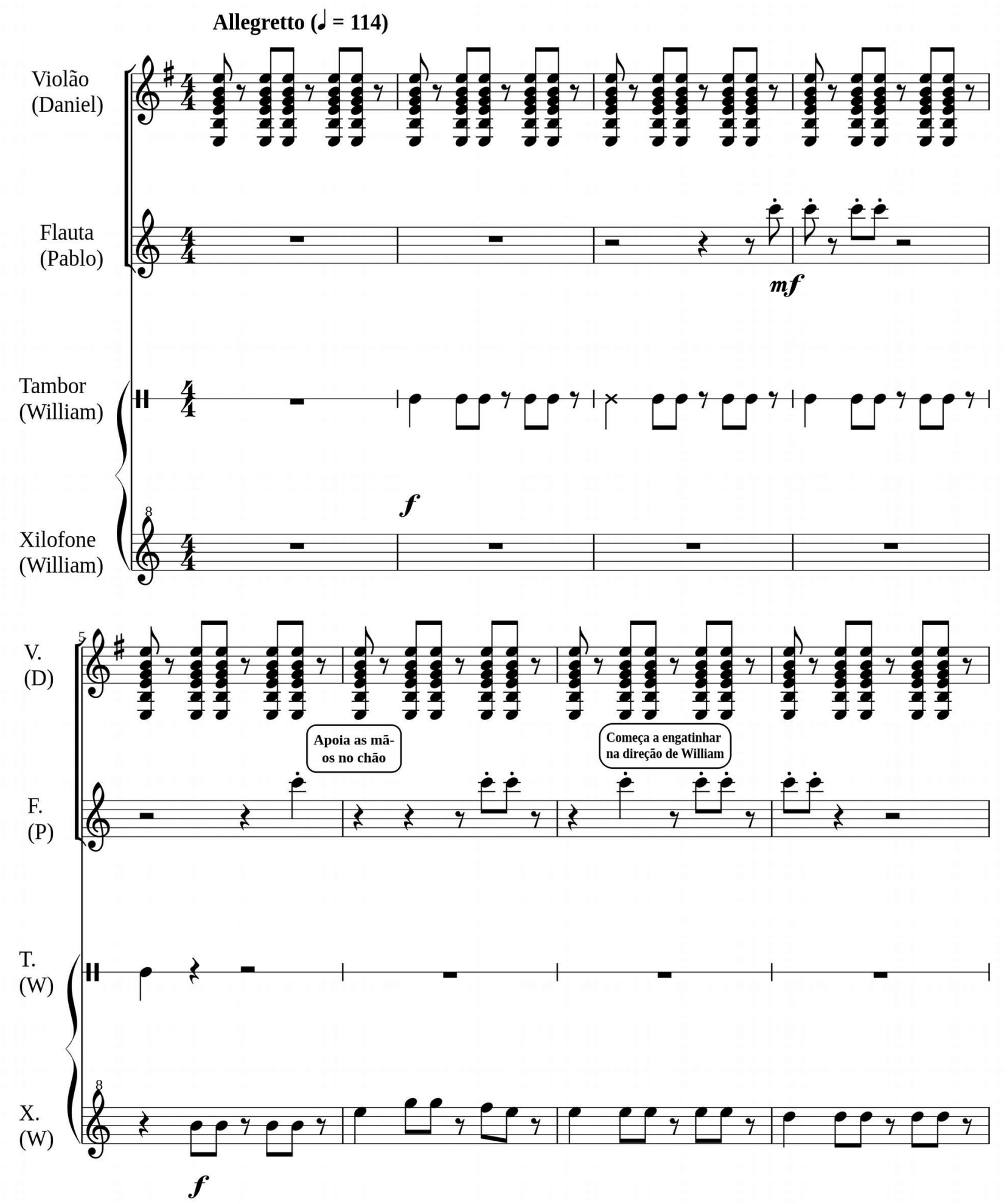


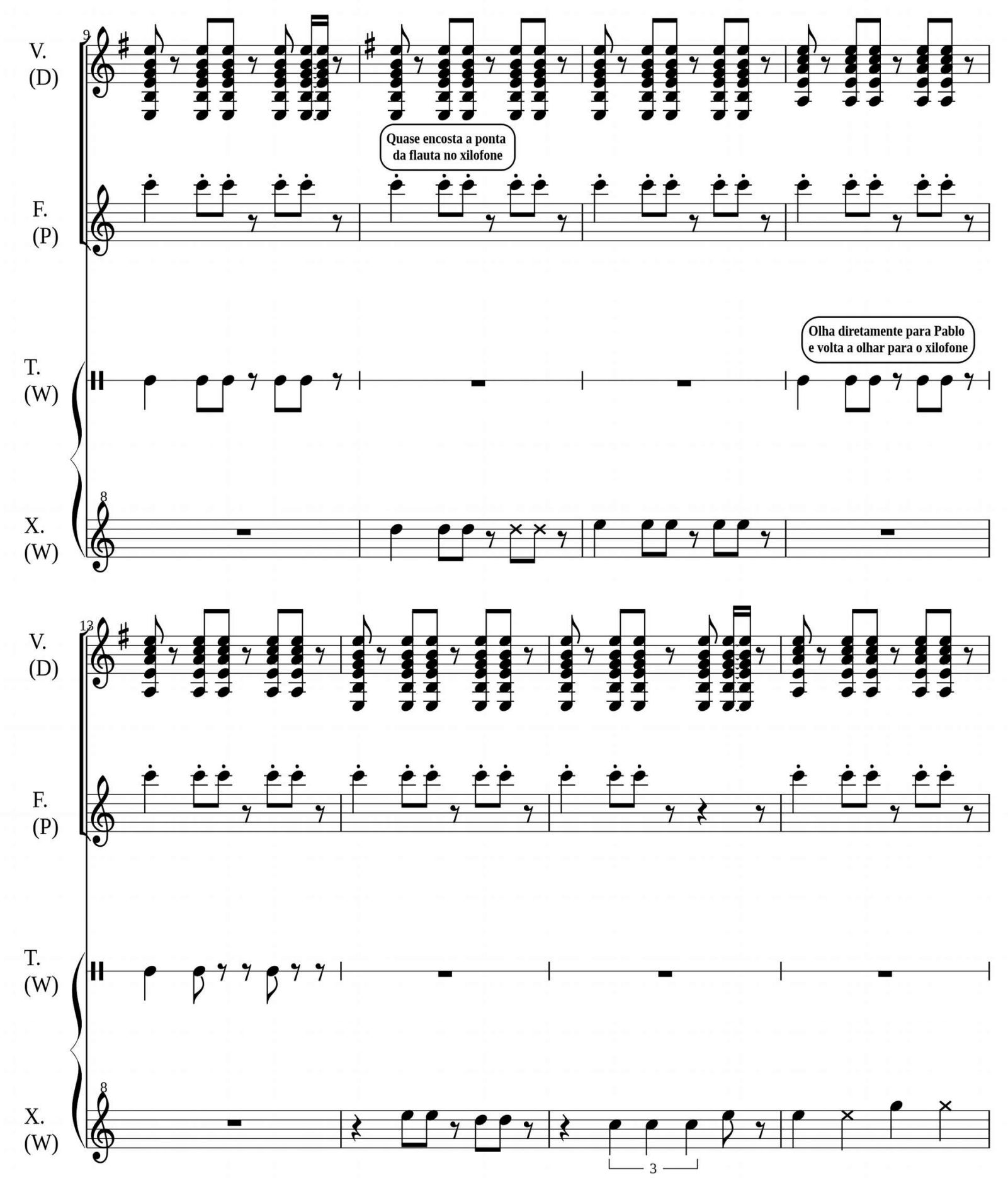




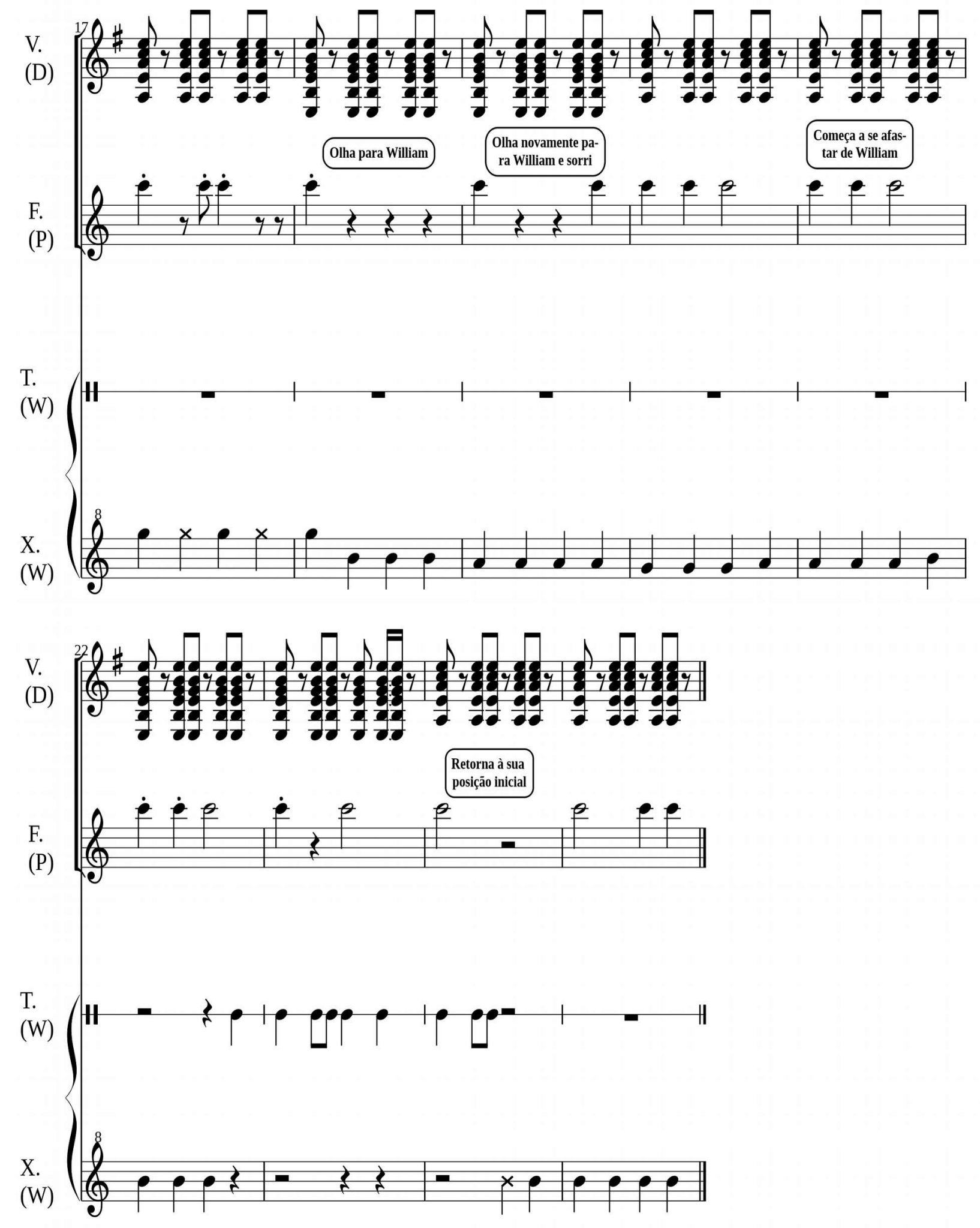

Figura 16 - Transcrição de segmento de improvisação na oficina de música de 06/07/13 
Logo após eu começar a tocar um acorde em um ritmo definido, William passa a reproduzi-lo no xilofone. Demora até o oitavo compasso para que Pablo, que parece estar buscando coordenar o ritmo do sopro com as batidas do violão e do xilofone, consiga acompanhar o resto do grupo. O mais interessante nessa cena é como Pablo e William conseguem, em um movimento que acompanha o motivo rítmico que introduzo no violão, passar da marcação do pulso da música a uma imitação e diálogo baseado nessa ideia musical compartilhada. Para $\mathrm{Pa}$ blo, isso parece ter um efeito terapêutico ainda mais importante, já que ele sai da sua posição passiva e toma um impulso em direção a William, sorrateiro e cauteloso, aproximando-se com a flauta com a nítida intenção de incomodá-lo. Não se deve desestimar o valor que esse movimento pode ter tido para ele, pois na sua história no grupo ele recém começa a tomar a iniciativa dessas brincadeiras. E o fato de que William não aproveitou essa oportunidade para golpeá-lo na cabeça com a baqueta do xilofone é um desses elementos que, ao mesmo tempo, escapam de nosso controle e compreensão e garantem o funcionamento da clínica. Ele pode ter tomado a decisão de não atacá-lo e assim incentivá-lo a adotar essa posição, regulando seu comportamento para não frustrar essa atitude? É difícil fazer uma afirmação desse porte, mas com certeza não haveria tempo para evitar que ele fizesse isso. E mesmo que a imagem da câmera dê a entender que William olha diretamente para Pablo ao longo dos compassos 12 e 13, a proximidade indica que ele estava em seu campo de visão durante muito mais tempo. $\mathrm{Na}$ verdade, ele parece mais ignorá-lo enquanto se concentra no que está tocando. A imitação e a coordenação aqui parecem ter o efeito de um "pedido de licença". No final, o certo é que este foi um encontro em que puderam compartilhar uma brincadeira capaz de fortalecer o laço entre ambos e potencializar uma atitude ativa por parte de Pablo, de uma maneira livre e segura.

Ao longo das primeiras sessões com Pablo, notamos como seu encontro com os adultos e as demais crianças é caracterizado por uma série de imitações. Por exemplo, após a improvisação da "Música assustadora" na sessão da oficina do dia 07/06/13, seguimos com o tema do medo e recito para o grupo uma história que será aproveitada por Pablo para imitar meus movimentos (Fig. 17). Trata-se da parlenda da "Bruxa no castelo mal assombrado", composta pelos seguintes versos:

\author{
Era uma bruxa \\ $\grave{A}$ meia-noite \\ Em um castelo mal-assombrado \\ Com uma faca na mão \\ Passando manteiga no pão
}


Como podemos acompanhar as ilustrações, meu movimento de levantar o punho cerrado (a), representando a faca da bruxa, é imitado por Pablo e William (b). Mas Pablo, ao contrário de William, incorpora o movimento de oscilar o antebraço - que faço representando a bruxa passando a manteiga no pão -, enquanto toca o xilofone, percutindo-o com a baqueta como se fosse a faca $(c, d)$.

a)
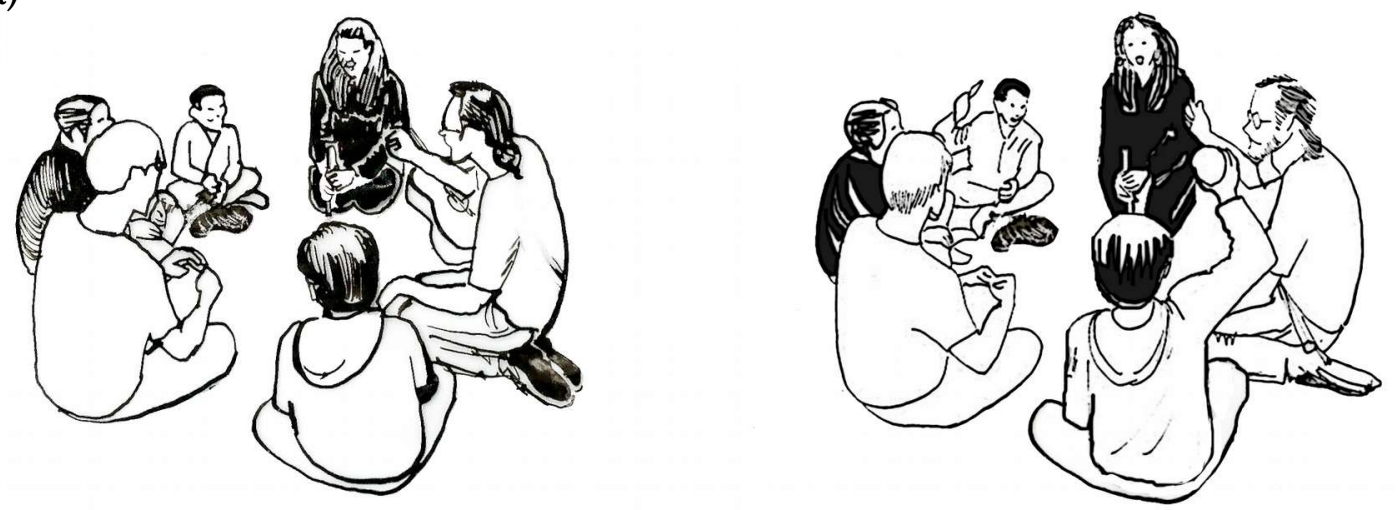

c)
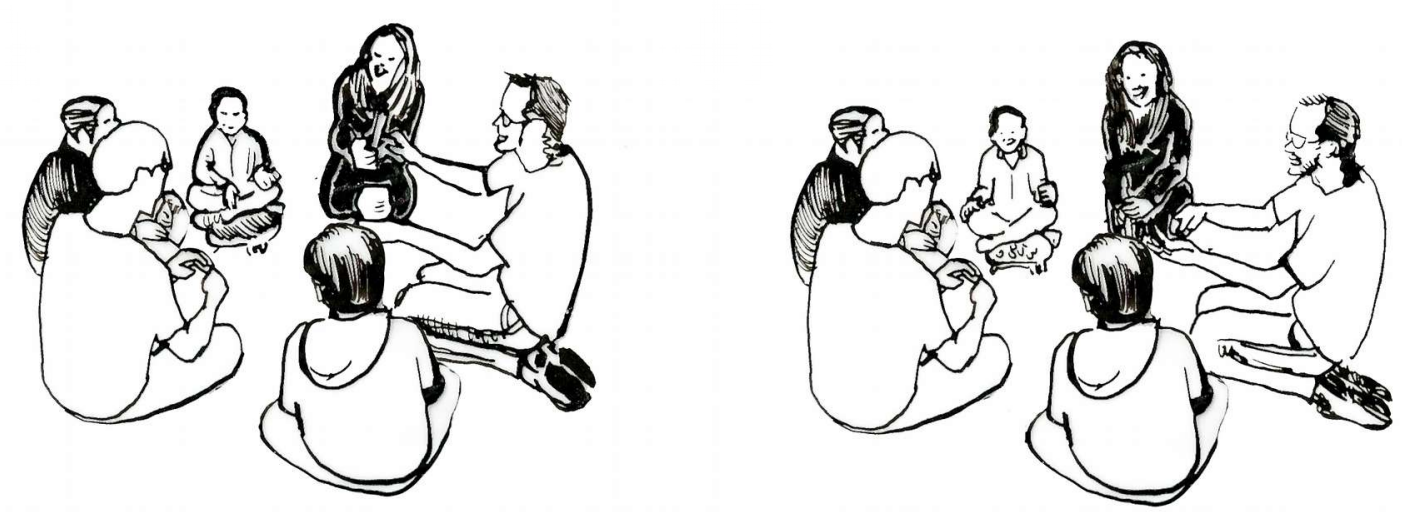

Figura 17 - Ilustrações da recriação da parlenda "Bruxa no castelo mal assombrado" na oficina de música de 07/06/13

A sensibilidade de Pablo para imitar os movimentos dos outros é algo que chama a atenção quando assistimos aos vídeos das sessões da oficina. Em outro exemplo, vemos a sequência de imitações que Pablo faz de William (Fig. 18).

A pedido deste, toco no violão o motivo da música do filme “Tubarão”. Ele leva as mãos acima da cabeça, imitando a barbatana do animal (a), e os demais também fazem o gesto (b). Porém, além desse movimento, Pablo captura outros gestos de William para compor sua imitação: os braços tensionados para frente (c), que Pablo modifica, cerrando os punhos, (d) e as mãos sob o queixo $(e, f)$. Imediatamente depois da imitação, ele interage com Beatriz, mas de uma maneira completamente diferente. Ela finge que é um tubarão prestes a mordê-lo e o “ataca” com as duas mãos sobre a sua coxa esquerda, fazendo uma onomatopeia, "nhect!".Ele 
logo em seguida faz o mesmo nela, reproduzindo também o som. Mais do que uma simples reprodução, trata-se de um modo de interação mais complexo, envolvendo a troca de turnos e

a)

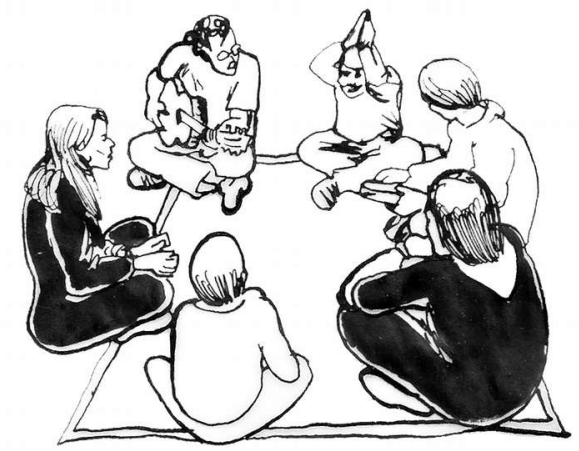

c)

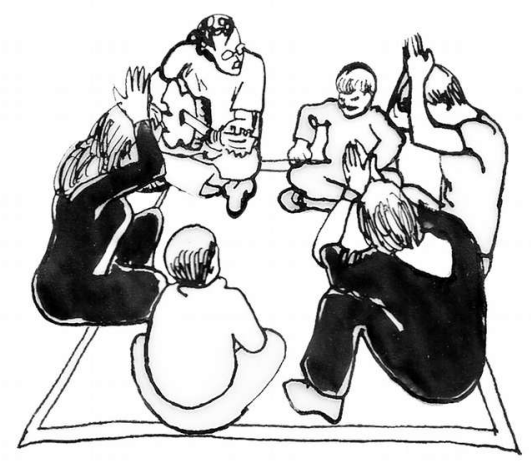

e)

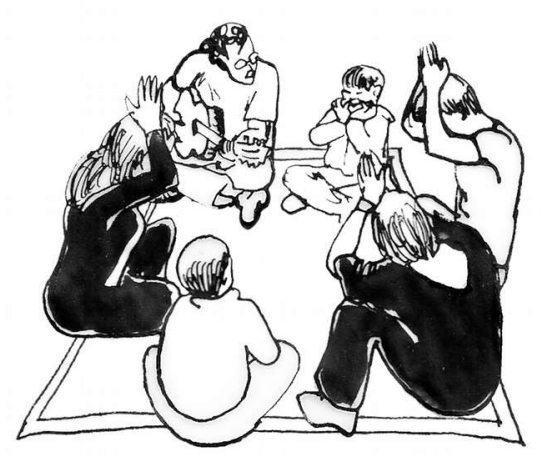

g)

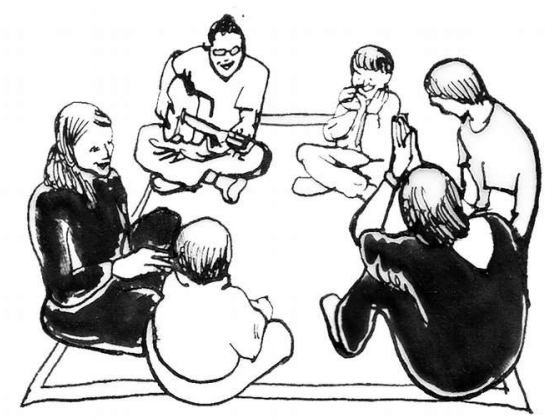

b)

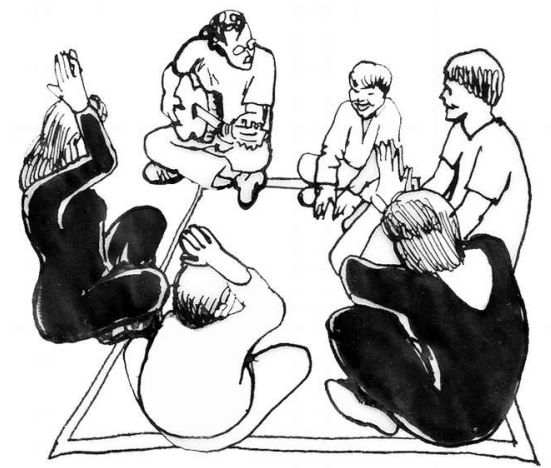

d)

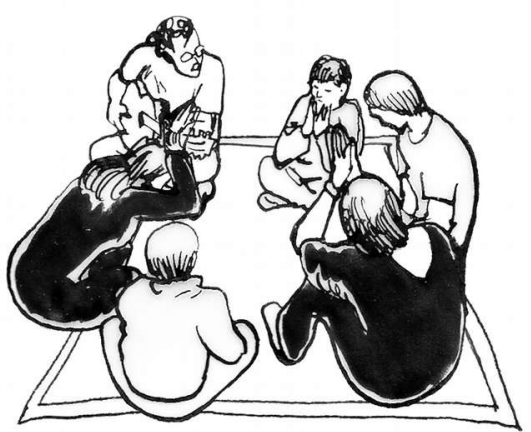

f)

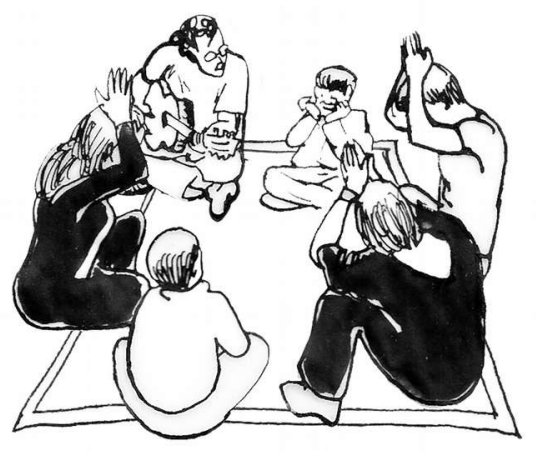

h)

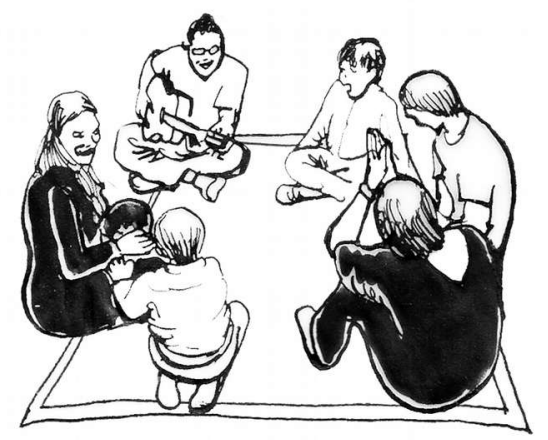

Figura 18 - Ilustrações da apresentação do motivo musical do filme “Tubarão", na oficina de música de 06/07/13 
inserida em uma relação de reciprocidade. $\mathrm{O}$ ato de imitar, tendo uma frequência tão elevada, gera uma série de inquietudes na equipe clínica, o que nos leva a elaborar a hipótese de que poderia indicar um estado do desenvolvimento anterior aos processos de identificação, e que Pablo necessita experimentar imitações dos atos expressivos dos outros como forma de constituir um repertório singular próprio.

É importante ressaltar que as imitações de Pablo não necessariamente são simples reproduções dos comportamentos do outro. Às vezes, ele antecipa um movimento, coordenando-o com um parceiro. Na figura 19, Beatriz faz um grito agudo, dizendo que era um grito de bruxa (a). À simples vista, poderíamos dizer que Pablo imita William quando os dois se jogam no chão após o grito agudo. A microanálise do vídeo, por outro lado, mostra como Pablo, após ouvir o grito, se vira para William (b) e inicia o movimento de jogar-se antes dele (c), quando este joga o chocalho para o alto, terminando os dois no chão. Possivelmente ele não só antecipa um movimento coordenado, que já havia sido executado previamente pelos dois, como também conduz William a jogar-se no chão junto com ele. Essa inferência pode ser feita porque, apesar de William estar de costas para a câmera, não se identifica um movimento de rotação do pescoço que deslocaria seu foco visual de Beatriz para Pablo (assim como vemos este fazer). Isso explica também o porquê de Pablo iniciar e terminar o movimento antes que William.

a)

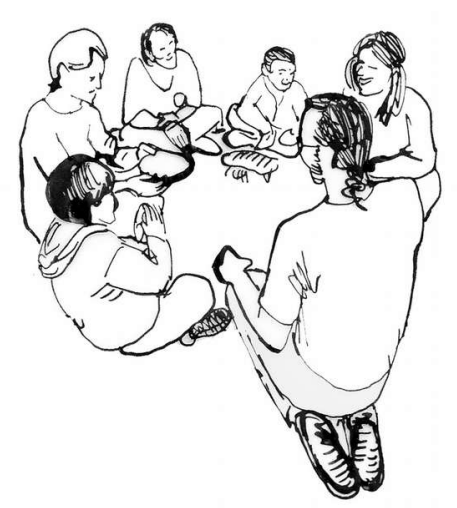

c)

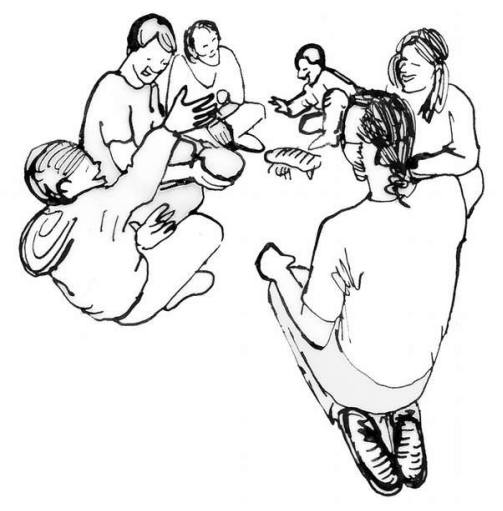

b)

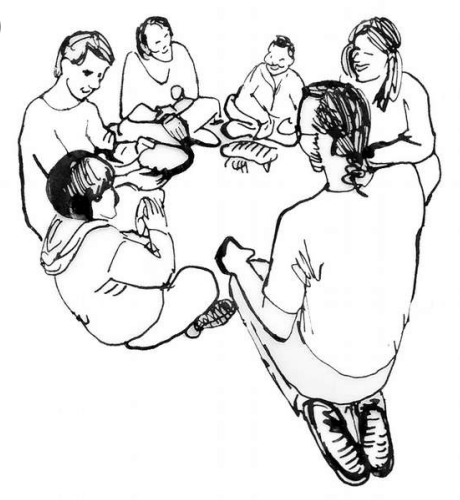

d)

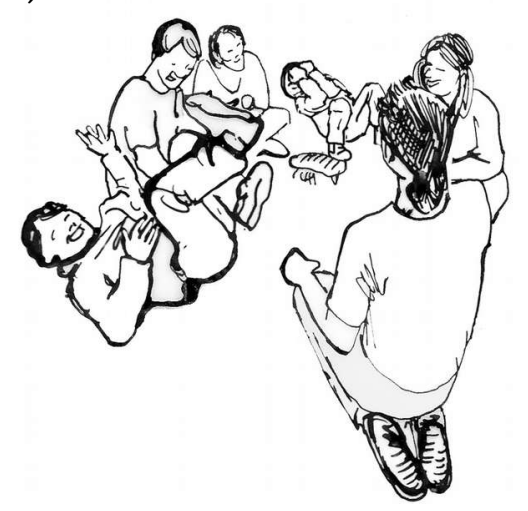

Figura 19 - Ilustrações do movimento de Pablo e William na oficina de música de 06/07/13 
O tema do medo, como vimos, vai ganhando um espaço cada vez maior na oficina, culminando em uma sessão importante para o tratamento de Pablo, no dia 23/08/13. Nesse dia, cantamos a canção "Os indiozinhos" (Fig. 20). Pablo coloca dois chocalhos sobre o tambor e se levanta (a), senta-se em uma cadeira fora da roda, cruzando os braços no apoio da cadeira e apoiando a cabeça como se estivesse dormindo (b). William atira o xilofone em cima do tambor e desmonta a sua instalação, o que faz com que Pablo organize tudo de novo e volte à sua posição. Quando cantamos o verso “[...] quando o jacaré se aproximou”, ele pula da cadeira e corre para o colo de Thales (c), insistindo em ficar ali, apesar de Thales balançá-lo no ritmo da canção e tentar colocá-lo de pé.

a)

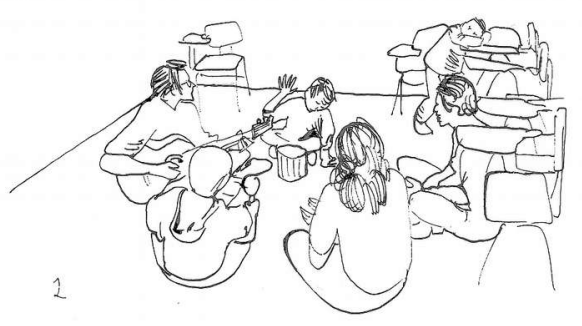

c)

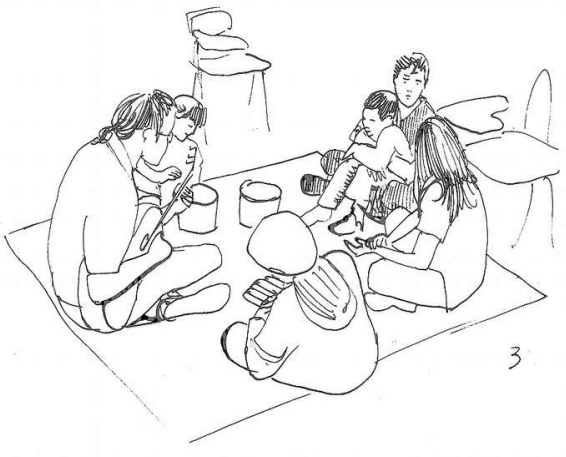

e)

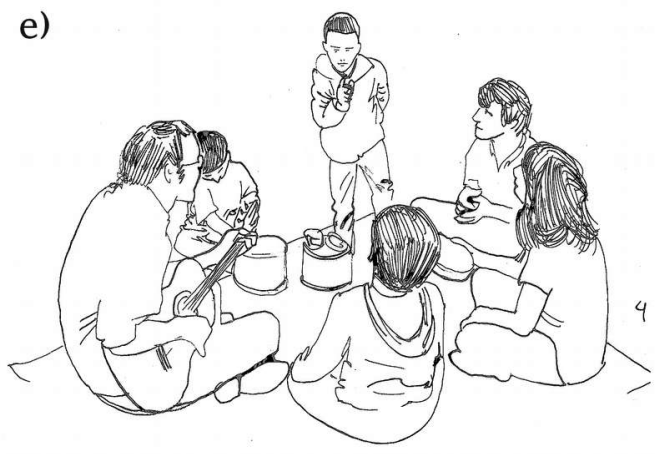

b)

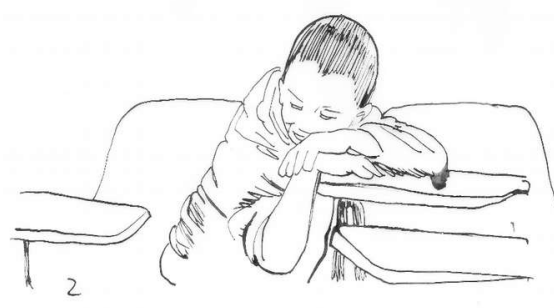

d)

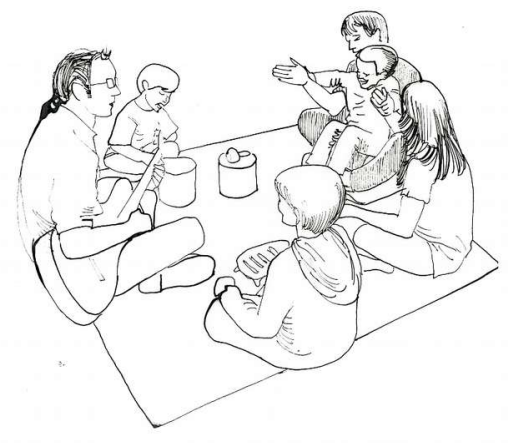

f)

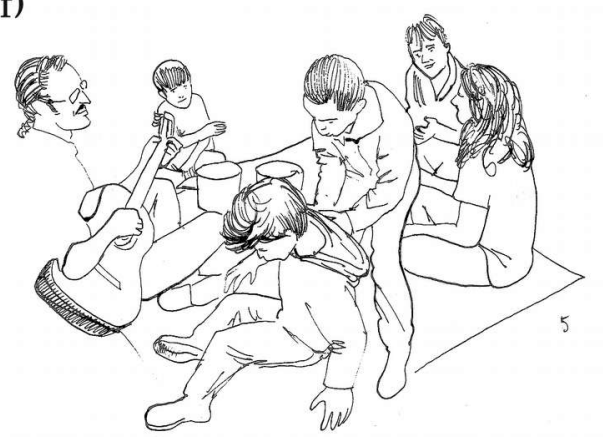

Figura 20 - Ilustrações da recriação da canção "Os indiozinhos" na oficina de música de 23/08/13 
Digo "parece que o Pablo quer ficar sentado" e ele cai no colo de Thales, agarra as suas mãos e imita o gesto que faço com as mãos (d), coreografando a boca do jacaré. Essa brincadeira vai durar um bom tempo, sempre usando as mãos e o colo de Thales como um apoio. Mesmo depois de a canção já ter terminado, fazemos uma improvisação com as sílabas "ja-caré", marcando o ritmo com o qual chocamos as mãos. Ele me diz que mata o jacaré. A performance parece ter um efeito tranquilizador para Pablo, que agarra as mãos de Thales e as faz chocar com força, o que o diverte. Quando William se aproxima dele, fingindo ser o jacaré, $\mathrm{Pa}$ blo o empurra com energia, e quando ele em seguida desmonta novamente a escultura de tambor e chocalhos, Pablo se levanta com o dedo indicador em riste e avança para cima de William (e), golpeando-o com alguma força (f) e surpreendendo a todos.

Praticamente um mês depois, na sessão do dia 27/09/13, cantamos "Ciranda, Cirandinha”, adaptando a segunda parte da canção, assim como havia sido feito na semana anterior ("Por isso, Seu ... / entre dentro dessa roda / diga a sua comida favorita, / diga adeus / e vá se embora”). Ao chegar na vez de Guilherme, há um grande interesse na resposta inusitada: "guioza". Ao perguntarmos quem sabia o que era aquilo, Pablo acena com a cabeça e diz que "é quando a gente pega um bicho da caverna”. Impressionados, chegamos à conclusão de que seria uma comida "muito perigosa", mas quando Guilherme lhe pergunta "o que acontece quando a gente pega o bicho dentro da caverna?", ele responde: “a gente tem que matar o bicho, para ele não pegar mais".

É perceptível a insistência por parte de Pablo em trazer suas imagens de medo às atividades do grupo, de expressar como ele mata o seu "bicho", que agora passa a ser um ingrediente no recheio do pastel preferido de outra pessoa. O tema já não é tão frequente no atendimento individual, mas quando Pablo e Thales brincam, em um faz de conta sobre "bichos", é Pablo, e não Thales, quem é amigo do monstro. Igualmente, quando a temática do Dia das Bruxas emerge na sessão do dia 01/11/13 na forma de máscaras e narrativas de vampiros e fantasmas, Pablo se diverte mostrando como são os dentes e as risadas dessas figuras de terror. Aproveito a ideia de transformação associada a esse tema e proponho um jogo chamado "Canção da Bruxa", em que cada um pode lançar um feitiço sobre os demais após um coro que fazemos em tutti:

Pirlimpimpim, pirlimpimpim

Abracadabra, sim, salabim

Vou transformar vocês assim 
O primeiro feitiço é o meu, e todos no grupo agora são gatos que miam e mostram as garras. Depois é a vez de William, que faz com que todos se transformem em coelhos, e de Thales, em galinhas. Na vez de Pablo, todos entendemos que ele diz "bomba", porém ele nos corrige dizendo "não, pomba", agitando os braços como se fossem asas. Ele complementa, dizendo que a pomba fala para sua mãe que alguém havia jogado uma pedra nela. Thales pergunta quem havia feito essa maldade e ele responde "o bicho grande que come todas as pombas" e apresenta mais um detalhe "aí, ele joga uma pedra grande e come...”. Digo a ele que precisaríamos inventar um feitiço para acabar com o tal bicho, mas ele rapidamente prossegue a história, dizendo que "aí, o policial da pomba matou o bicho grande", golpeando alternadamente os cocos no chão em um andamento alegro, e depois fazendo um som que nos lembra a sirene de um carro de polícia, mas que Pablo diz ser de uma ambulância. Essa é uma das últimas vezes que ele traz ao grupo o seu "bicho", agora delegando a uma nova figura, a da autoridade, a função de matá-lo.

É possível que a ambulância, e sua respectiva sirene, sejam um efeito a posteriori de uma intervenção ocorrida algumas sessões antes. Trata-se de uma proposta que surge nas reuniões de equipe, quando pensamos que seria interessante reunir alguns temas que emergem nas situações de atendimento individual e em grupo para compor para Pablo uma canção pessoal, por exemplo sobre o tema do medo ou da fralda. Chegamos à conclusão de que a composição da canção deveria estar orientada a narrar uma história cujos elementos representassem os conflitos experimentados por Pablo.

O tema é escolhido após uma intervenção a partir de um relato trazido por ele na oficina de 16/08/13. Em meio a uma conversa sobre o fato de o relógio da sala não estar funcionando, o significante "quebrado" leva Pablo a contar que havia ido ao médico no dia anterior, após um golpe na cabeça ao cair sobre a pia da cozinha. Apesar de o machucado ter sido leve e ele ter recebido alta logo após alguns exames, imagino que a situação toda provavelmente foi emocionalmente intensa, e Pablo parece contá-la com nervosismo, olhando para baixo, ora girando o dedo em volta do aro do tambor e levando-o à boca, ora agarrando o chocalho com as duas mãos.

Proponho então fazermos uma improvisação com os sons da história que ele traz. Começamos com os passos de Pablo, marcados em andamento andante pelo xilofone e pelo tambor, seguidos pelo tropeço e o golpe na mesa, representados por uma batida no pandeiro. Pergunto se ele chorou e simulo o choro, mas logo vem a vó do menino, com seus passos feitos 
por todos em um gesto crescendo e accelerando, e diz para que ele pare de chorar. Com o som do carro que o leva ao hospital, Pablo se torna mais animado e ri quando imito com o pandeiro os movimentos do volante. Ficamos alguns instantes reproduzindo os sons das sirenes das ambulâncias e, depois de Pablo contar que o médico havia pedido para que ele não batesse mais a cabeça, improviso uma estrofe:

Médico, médico, médico

O médico disse que o Pablo tava legal

Mas que bater a cabeça faz mal

E aí ia ter que voltar pro hospital

Para ressaltar o final positivo da história, repito a imitação do volante do carro, que agora volta para casa, agarrando o pandeiro com as duas mãos e fazendo um forte "vrrrrrr". Pablo ri novamente e responde afirmativamente quando lhe pergunto se havia gostado daquela "Música do hospital".

Após o êxito desta improvisação narrativa apresento, na semana seguinte, uma canção pessoal composta a partir da ida de Pablo ao hospital. Trata-se de uma continuação da canção "O pato pateta", que aproveito por ter um apelo interessante entre as crianças, usando a mesma linha melódica em uma segunda parte com uma nova letra:

O rato ladrão roubou o queijo.

Fugiu do gato, mandou um beijo.

Comeu demais, até passar mal.

Ficou com dor de barriga, foi pro hospital,

Quis ir no banheiro, sentou na privada

Puxou a descarga, deu uma risada

Caiu na ratoeira, pulou a janela.

Tantas fez o moço...

O personagem é apresentado como esperto e aventureiro, porém enfrenta um revés que cria uma tensão na história: uma dor de barriga. Contudo, em lugar de me referir ao golpe na cabeça, prefiro utilizar o tema do banheiro. A passagem pelo hospital retoma as características da narrativa da improvisação, rápida e com um final positivo, representada pela risada de satisfação do rato após fazer as suas necessidades na privada.

A canção é recebida com atenção pelas crianças, porém não noto nenhum efeito específico em Pablo. O que causa maior euforia, no entanto, é a possibilidade de uma nova coda. Isso fica claro quando, na primeira apresentação da canção, William repete o fim da canção original, dizendo "E foi pra panela", e eu pergunto "Ihh, esse rato virou comida. Uma sopa de 
rato?”, o que nos faz rir. Apresento essa sequência nas recriações de “O pato pateta” nas sessões seguintes, e as crianças passam a disputar quem termina a canção, o que me leva a repeti-la várias vezes para que todos possam fazer seus finais. Em 13/09/13, pergunto para onde mais o rato poderia ir, após William ter respondido que ele havia ido para a ratoeira. "E foi pro ratoeiro", diz Mathias, o que também é motivo de risadas.

Esses e outros efeitos são recolhidos posteriormente. Na sessão do dia 25/10/13, Pablo me diz que o rato foi para a Lua. Perguntamos o motivo de ele ir para lá e ele nos diz que havia sido para buscar comida, pois tinha uma família na Terra que não estava conseguindo alimentar. Novamente pensamos que Pablo emprega as canções como uma forma de alinhavar os seus conflitos, neste caso a sua relação com o pai.

Muitas vezes, durante os jogos de alternância, quando Pablo é convocado pela canção a se expressar, ele retoma uma postura inibida, falando para dentro, ou ficando em silêncio, quase corando de vergonha. $\mathrm{Na}$ canção de encerramento do dia 13/09/13, por exemplo, ao ser perguntado qual instrumento ele tocaria, Pablo fala "tambor" muito baixo, sem que se possa escutá-lo. Depois de diversos pedidos para que dissesse o nome do instrumento, aos quais ele se recusa, peço a ele que o diga enquanto bate na pele do instrumento. Aí sim escutamos com força “tam-bor”, cada sílaba acompanhada por uma batida. O mesmo ocorre no dia 20/09/13, quando ele diz, na minha vez de apresentar o instrumento, “violão!” com uma voz forte e grave.

Em diversos sentidos, o tratamento institucional tem efeitos positivos em Pablo. Desde o início de agosto de 2013, notamos como Pablo apresenta convites progressivamente mais explícitos para William, em um movimento que se iniciou pelo menos um mês antes, quando ocorre a brincadeira provocativa de aproximar a flauta do xilofone. $\mathrm{O}$ tema das figuras de medo parece persistir, porém com algumas modificações, em uma frequência menor e com outros sentidos e possibilidades associados aos bichos. Ao mesmo tempo, outros temas emergem, como a imagem do pai e da família. As imitações, tão frequentes no início, diminuem progressivamente, e parecemos encontrar uma criança mais feliz e mais segura. É um amadurecimento que se reflete tanto no abandono definitivo das fraldas quanto em sua maneira de vestir-se, agora mais adequadas a um menino que a uma criança pequena. Todas essas mudanças podem ser verificadas tanto na presença quanto na ausência daquele que foi durante esse tempo seu grande companheiro, William. É possível mesmo identificar alguns traços dele que Pablo parece ter se apropriado, como em alguns momentos em que ele corre pela sala enquanto os demais brincam de massinha, ou quando ele interrompe a hora de uma criança contar qual é o 
presente que quer ganhar de Natal falando alto e recebendo uma bronca de Beatriz, que pede para que ele pare de falar. Essas são todas novidades que indicam o curso de um processo terapêutico em curso. Quando encontro sua avó no final do grupo terapêutico, em março de 2014, ela me diz que ele mudou completamente, que é um outro menino. Sou forçado a concordar com ela.

\subsection{Camila}

Camila tem 6 anos e é a filha mais velha de sua família. Teve uma infância normal até o primeiro ano e meio de vida, quando apresentou uma série de ataques de epilepsia. Isso atrapalhou de alguma forma seu desenvolvimento, pois ela deixou de falar e olhar nos olhos, conforme o relato da mãe. Apresenta um comprometimento severo no relacionamento com os demais, que se estende até o início do seu tratamento no Núcleo. Ela chega com uma produção muita reduzida de fala, emitindo poucas palavras, como "Não" e "Tchau", junto a outros sons vocais.

Em seu atendimento individual, Camila demonstra desde o princípio um grande interesse pelas sonoridades dos objetos, dos animais e do corpo, demonstrando ser essa uma via de comunicação e de compartilhar uma experiência com o outro. Surgem aí também os comportamentos de sobrepôr camadas e mais camadas de materiais como fita adesiva ou massinha. No primeiro encontro com Guilherme, durex é aplicado sobre todo o corpo de uma boneca. No encontro seguinte, é a vez de alguns desenho receberem essa cobertura. Naquele dia, ela só entra na sala de atendimento após Guilherme realizar uma intervenção com uma folha em branco, na qual eles contornam a sua mão e a dele ainda na sala de espera. $O$ contorno das imagens para colorir e das letras é uma das marcas que vão se estruturando ao longo do seu tratamento, em direção ao contorno da figura humana.

$\mathrm{Na}$ primeira sessão do grupo da manhã, Beatriz

perguntou à Camila como ela se chamava, mas ela permaneceu em silêncio. Juliana disse que ia dar uma dica e falou que seu nome começava com a letra C. Bia arriscou "Carolina", esperando ao menos um sinal de negação, mas ele não apareceu. Arriscamos novamente: "Carla"? Nada da parte de Camila. Bia perguntou se alguém sabia seu nome. Sofia e Pablo levantaram a mão e disseram que sabiam. Sofia disse: - É Cami! (Relato do Grupo Terapêutico, 03/05/13). 
A situação se repetiu na semana seguinte, na primeira sessão da oficina de música (10/05/13), como vimos anteriormente. Nesse mesmo dia, após a apresentação e a distribuição dos instrumentos, Camila escolheu a flauta doce e passou a soprá-la com uma pulsação bas tante marcada em andamento andante, sentada em uma cadeira afastada da roda no piso, enquanto começamos a canção de abertura da oficina.

Na vez da Camila, todos a olhamos e sentimos que ela, apesar de estar tocando a
flauta durante toda a canção, usou seu momento para fazer um som diferente, colo-
cando a mão sobre a cabeça. Mesmo sentada fora da roda, fez o som do instrumento
escolhido de acordo com o intervalo proposto pela música. Foi bem impressionante
para todos nós! (Relato do Grupo Terapêutico, 10/05/13).

Após cantarmos duas canções, "Atirei o pau no gato" e "O pato pateta", começamos uma ciranda em pé, da qual Camila participou dando-me as mãos e parecendo estar envolvida e aproveitando a atividade enquanto girávamos pela sala. Em seguida, ela pediu para sair da sala e retornou, porém quando quis sair novamente não permitimos que ela saísse, tentando convencê-la a participar da atividade com o grupo. Ela se mostrou bastante aborrecida e, em seguida, furiosa com esse impedimento, soltando um grito agudo e atirando a cesta de lixo no chão com força. Antes de sair, tampou os ouvidos, dando a impressão de que havia muito barulho para ela. $\mathrm{Ha}$ via passado pouco mais do que a metade da duração da oficina e Camila já se sentava ao lado de sua mãe na sala de espera.

Depois de faltar na semana seguinte, na outra sessão (24/05/13), Camila nem chegou a entrar na sala de atendimento durante o grupo da manhã e já quis voltar para a sala de espera. Porém, ao chegar ali não encontrou sua mãe, tendo em vista que ela participava de uma reunião junto com os outros pais para a apresentação da pesquisa e assinatura do Termo de Consentimento Informado. A ausência da mãe a desesperou e ela começou a gritar, cuspir no chão e chorar, arremessando um sapato e um brinquedo que ela carregava. Como se dirigia para o corredor de acesso ao bloco de atendimento, Beatriz a acompanhou, primeiramente até o telefone público, com o qual Camila brincou dizendo "Alô, alô", talvez buscando um contato com a mãe, e em seguida até um trailer de comidas, pedindo um pão de queijo com sons de "mmm, mmm". O passeio e o salgado pareceram ter um efeito tranquilizador e Camila voltou ao grupo, oferecendo o pão de queijo às demais crianças. Em seguida, novamente acompanhada de Beatriz, ela foi até a sala onde sua mãe estava e não quis participar da oficina de música naquele dia e nem na semana seguinte (07/06/13). Nas reuniões da equipe clínica, discutimos até que ponto o fato de ela não ter encontrado a mãe na sala de espera comprometeu a sua partici pação na oficina. $\mathrm{O}$ manejo de sua angústia permanece sendo um desafio para a equipe. Ao 
contrário de William, que pode produzir um enunciado do tipo "Já chega, minha cabeça está pegando fogo" ou desviar o foco daquilo que lhe incomoda, Camila parece não contar com os recursos para enfrentar as situações em que se sente desconfortável.

Encontramos duas maneiras para que Camila pudesse participar da oficina. Em primeiro lugar permitir que ela ocupasse o corredor e outra sala próxima à sala da oficina, onde lhe eram oferecidos brinquedos e seus instrumentos favoritos como flauta doce e flauta de pã, além da companhia de um adulto. Essa flexibilidade permitiu que ela estivesse, ainda que à distância, ao alcance da música. É assim que, quando começamos tocar a canção "O pato pateta", na sessão do dia 14/06/13, ela pronuncia imediatamente a palavra "pato". Uma segunda "concessão" foi permitir a presença de sua mãe no corredor externo à sala da oficina com uma cadeira que lhe permitisse a maior comodidade possível, mantendo a porta aberta de modo que Camila pudesse transitar livremente entre o espaço da música e a proximidade materna. Da mesma maneira, são oferecidos instrumentos para que ela acompanhe o grupo, junto com invocações como “o que será que a Camila está fazendo?” ou “qual será a música que a Camila quer tocar?”. Nessa mesma linha, no final da sessão, ela pode participar da canção de encerramento à distância e lhe é dado um tempo para que toque seu instrumento. Com o auxílio do vídeo, confirmamos que, na sessão do dia 21/06/13, ela se encontra fora da sala de atendimento mas de pé em frente à porta de entrada. Balançando a flauta de pã pela corda que está amarrada ao instrumento, ela o golpeia no chão em um ritmo coordenado com o da canção que tocamos dentro da sala, sentada na cadeira, com os olhos fixos na mãe, que está de pé à sua frente. É nítido o sorriso em seu rosto enquanto chacoalha o instrumento, contrastando com o semblante de reprovação da mãe, provavelmente pelo fato de a filha estar fazendo algo errado. Não é pos sível, portanto, interpretar se a expressão alegre de Camila se refere a uma tentativa de mostrar à mãe seu interesse e satisfação com a música ou uma postura desafiante pela suposta trans gressão.

Outra estratégia para aumentar a participação da Camila no grupo foi o uso da canção de abertura do desenho animado "Peixonauta", construída sobre a melodia da canção tradicional "Quem me ensinou a nadar". Originalmente pedida anteriormente por William, ela interessou e atraiu a Camila, que entrou rapidamente na sala após sua mãe avisá-la que a estávamos tocando na sessão do dia 14/06/13. Ela se senta em uma cadeira no canto e troca a flauta doce pela câmera que estava sendo usada por William. Aparentando estar mais interessada no achocolatado de caixinha que trazia consigo que na canção ou em qualquer coisa que estivesse 
acontecendo ali, ela gravou com o equipamento durante alguns minutos. As imagens que registrou, ao contrário daquelas de William, não possuem movimento de zoom, tanto que começam com uma imagem desfocada e com seus dedos tapando a lente. Em determinado momento, Thales a ajuda a regular o foco e ela passa a alternar entre a filmagem de sua própria mão, o achocolatado, as paredes e o teto da sala, os instrumentos que estão sendo tocados. Então, o grupo todo aparece, os outros participantes a saúdam e vemos que ela responde acenando sua mão adiante da câmera. Em um momento, William se levanta e oferece a flauta doce a Camila, provavelmente com a expectativa de receber o equipamento de volta. Ela aceita a flauta, mas não lhe entrega a câmera, e continua filmando enquanto podemos ouvi-la soprando notas curtas seguidas de uma nota longa, próxima ao tempo de uma semibreve no compasso em que tocamos, repetidas vezes. Toda essa cena ocorre enquanto o grupo toca uma longa versão da canção do "Peixonauta", repetindo as estrofes, explorando partes instrumentais improvisadas, alternando a letra com a de "Peixinhos do Mar" e variando entre dinâmicas de alto e baixo volume. O fato de permanecer na sala, a troca de acenos, o ato de tocar a flauta no ritmo da canção, tudo isso nos faz pensar que a música possibilitou que ela interagisse conosco de uma forma que sem ela seria distinta ou impossível. A música parece modular o campo social de acordo com a sua dinâmica estrutural, rítmica e afetiva, o que pode ter permitido à Camila um encontro com a alteridade, como verificamos nas interações sociais coordenadas que se desenvolvem durante o tempo da canção.

Nesse sentido, uma intervenção para Camila surgiu na sessão do dia 28/06/13, com o uso de uma canção pessoal. Nesse dia, ela não quis participar do grupo da manhã e a encontrei na sala de espera, acompanhada pela Juliana. Antes da minha chegada, elas haviam encontrado alguns folhetos contra um recente aumento da tarifa do transporte público que estampavam a palavra "Não", e riram juntas repetindo a palavra, em um contexto bem diferente do que a $\mathrm{Ca}$ mila costuma usá-lo. Após diversas tentativas de acompanhá-la à sala de atendimento, resolvi acompanhar seu convite para sair do bloco. Enquanto caminhávamos, comecei a reproduzir alguns sons que ouvíamos pelo caminho, dos passos e dos pássaros. Isso pareceu interessá-la pois passou a alterar o andamento dos passos, construindo frases rítmicas pontuadas por saltos. Ela me levou até o trailer de comidas e praticamente exigiu, em meio a sinais de apontar e sons de “mmm”, que lhe comprasse um pão de queijo, da mesma forma que havia feito antes com Beatriz. Concordei, com a condição de que voltássemos ao grupo em seguida, e no caminho repetimos a mesma brincadeira com os passos. Porém, dessa vez, fui cantando a canção do Peixo- 
nauta, alterando os versos originais da canção:

\section{Qual será o mistério \\ Vem a POP indicar \\ Nós queremos uma pista \\ A POP diz qual é}

com a substituição do nome da bola POP, que no desenho conduz os personagens a diversas aventuras, pela palavra Cami, diminutivo de Camila. Essa alteração sutil parece ter sido percebida por ela, pois em um momento me olhou com uma expressão intrigada e seguiu caminhando, reduzindo a velocidade, talvez para escutar a repetição da canção que agora tinha seu nome. Infelizmente, não houve oportunidades para repetir essa intervenção.

A participação reduzida de Camila na oficina de música nos fornece poucas informações para discussão das orientações clínicas, fomentando nossa expectativa de que, em algum momento, fosse possível construir com ela um sentido para a participação no grupo. Ao longo das sessões, encontramos indicações de que a situação da oficina poderia ser demasiado exigente para ela, seja pelos procedimentos propostos cobrarem em demasia a participação em um grupo e favorecerem a exposição pessoal, seja pela intensidade sonora estar acima do seu limiar de sensibilidade, seja pela presença de muitas pessoas ou pela separação com a mãe, mas todos es ses fatores não ocorreram com regularidade ou foram completamente esclarecidos. Por outro lado, os avanços em seu tratamento individual em termos de compartilhamento de experiências, comunicação não-verbal e demandas ao outro nos mostravam que algo do laço social e da musicalidade estavam nela preservados. Além disso, sua participação, tanto na canção de abertura e na ciranda da primeira sessão, quanto no episódio da canção do "Peixonauta", para men cionar alguns exemplos, indicavam que a música e os sons poderiam ser para ela uma possível via de comunicação e de relacionamento com o outro no contexto da oficina.

No início do segundo semestre, Camila faltou uma série de vezes e não quis participar dos grupos quando veio. Porém, na sessão do dia 06/09/13, quando o grupo passou a acontecer na sala de ateliê do Instituto de Psicologia, o grupo pareceu encontrar uma outra Camila, bem diferente daquela dos atendimentos anteriores. Naquela sessão, em meio a uma brincadeira desorganizada durante a canção "Cocoricó", William pisa no pé de Sofia, vem para trás de mim e começa a correr em círculo atrás do Pablo. Sofia, Julia e Thales começam uma roda. Eu faço uma segunda repetição da canção, desta vez mais fraca e me agachando. Todos fazem o mesmo, com a exceção de William, que bate o gonguê de cocos. Nos juntamos todos na roda, dando as mãos e cantando "Ciranda, cirandinha". William pede que giremos "muito rápido" e me 
empurra com força para acelerar o movimento, e as outras crianças também fazem o mesmo. Mudo o rumo da roda dizendo "para o outro lado"', tentando diminuir a velocidade do movimento de rotação. Próxima a nós, Camila está sentada junto à pia e Guilherme balança a sua cadeira no rimo da canção. Ela olha para a câmera e sorri (depois ela dará um tchau, acenando para a câmera). Proponho que cantemos a segunda parte da canção, em que cada um fica no centro da roda e diz seu nome completo. William não topa, fica fora da roda, buscando estar atrás de Sofia e, quando a roda para, volta a pisar no seu pé. Nos aproximamos de Camila e Guilherme e fazemos a brincadeira com eles. O relato do grupo terapêutico daquele dia ilustra com mais detalhes o que ocorreu.

Durante toda a oficina de música, a Camila esteve em um canto do ateliê sentada com o Guilherme. Ela brincava com a massinha e na segunda metade da oficina, o Guilherme começou a balançar a cadeira dela no ritmo em que o grupo cantava " $\mathrm{Ci}$ randa, cirandinha". Ela parecia estar se divertindo com isso e mesmo quando fizemos a roda sobre ela e o Guilherme, ela parecia um pouco surpresa, mas gostando. No final da oficina, o Guilherme e o Thales levantaram a cadeira da Camila, um de cada lado. Ela também parecia estar gostando disso, mas começou a reclamar dizendo várias vezes "não", depois que eles baixaram a cadeira atrás do resto do grupo. Ela parecia também dizer "niel", algo que entendemos como "Daniel" (Relato do Grupo Terapêutico, 06/09/13).

Pensamos se a "mudança" nela seria efeito da "mudança" da oficina para outra sala, talvez mais espaçosa, mas a mãe relata sentir que Camila está realmente diferente, interagindo mais com as outras crianças na escola. Em uma festa da família, na qual comparece um primo autista, Camila o consola em um momento de desorganização e diz a ele, "não chora, não chora". Essa transformação se confirma nas sessões seguintes do grupo da manhã em que Camila se diverte brincando e correndo, demonstrando estar interessada nas outras crianças, mostrandose sorridente e carinhosa com os outros. Ela pede que os adultos a ajudem em uma brincadeira na qual sobe em uma cadeira e dali salta para ser agarrada no ar pelo adulto. $\mathrm{Na}$ oficina de música, no entanto, sua participação até aqui se limita ao caso anterior. Nas demais sessões ela simplesmente deixa a sala assim que eu entro ou um pouco antes de a oficina começar. Durante as reuniões da equipe, essa mudança é comentada com otimismo, e a resistência a participar da oficina de música é pensada como uma indicação de que a duração do grupo da manhã é tempo suficiente para ela interagir dessa nova forma, ficando, em certo sentido, "cansada" do Outro.

O atendimento individual de Camila também mostra uma dinâmica de mudanças. As últimas sessões foram marcadas por uma interação com Guilherme por meio de demandas e pedidos, diferente de quando parecia haver um uso puramente instrumental do outro. Agora, 
ela pede para Guilherme cortar tiras de fita adesiva articulando sons, olhando-o nos olhos e rindo com algumas brincadeiras. Da mesma forma, ela aceita alguns de seus convites, por exemplo, desenhando o contorno das mãos ou do corpo de uma boneca em uma folha papel. $\mathrm{O}$ tema dos contornos do corpo se torna mais presente no atendimento individual, e eles fazem uma máscara na qual Camila fura os olhos.

Ao mesmo tempo, demandas mais explícitas começam a ser dirigidas aos outros, e $\mathrm{Ca}$ mila parece se interessar pelos gestos e objetos dos demais. Em uma sessão do grupo da manhã,

Camila estava mais ligada nos adultos, deitando no nosso colo, segurando-nos pelas costas, mas também interagiu um pouco com os meninos do grupo. Ao ver os meninos com as dobraduras de papel, Camila foi até a Bia e sinalizou fortemente que também queria uma. Ela apontava com o dedo, como se estivesse dando uma ordem para Bia fazer o chapéu. O chapéu feito parecia uma coroa, então brincamos que ela era a Rainha Camila (Relato do Grupo Terapêutico, 13/09/13).

Uma das direções de tratamento dirigidas a Camila se baseia na suposição de que as atividades de propriocepção possuem um caráter importante para ela pois auxiliam na delimitação do seu próprio corpo. É assim que passamos a acompanhar os ritmos das canções percutindo-lhe os ombros e as pernas. E por esse motivo interpretamos um gesto seu de sentar-se no colo de Beatriz, tirando-lhe o pandeiro das mãos, como um pedido de contato corporal. Beatriz passa então a tocá-la suavemente, acompanhando o ritmo da música. Ao mesmo tempo, o interesse de Camila pela câmera parece ter aumentado, e ela se diverte não só gravando partes de seu corpo, mas mostrando-o para quem esteja gravando. Esses dois gestos sugerem que ela de alguma forma começou a sustentar uma relação segura conosco, como também passou a oferecer-se ao contato com o outro. É assim, por exemplo, que Thales lhe tapa os ouvidos sem que ela resista ao toque. Quando, em seguida, ele retira as mãos, ela as segura e pede que ele os tape novamente.

As vocalizações de Camila também avançam em um ritmo acelerado, e ela já conta com um repertório de palavras maior no final do ano. É assim que, em novembro, Thales the diz "Bom dia, Camila", quando a encontra na sala de espera prestes a começar a sua sessão de atendimento individual, e ela surpreendentemente responde "Bom dia".

Sua presença nas sessões de novembro, apesar de ser ainda intermitente, permite que eu acompanhe mais de perto esse movimento. Às vezes ela permanece pouco, saindo 10 minutos após começada a oficina. Em outras, ela retorna quando a mãe está presente na sala. A presença da mãe não só a tranquiliza, mas também auxilia na sua participação nos momentos em que 
Camila é convocada pelas canções a dizer sua comida favorita ou o presente que quer ganhar no Natal. Sempre lhe damos a oportunidade de que ela se expresse, mas quando isso não ocorre, é a mãe ou outra pessoa quem responde por ela.

É essa alternância entre presença e ausência que sustenta uma outra direção de tratamento para Camila, focada na sustentação de um lugar que seja o seu, de onde ela possa interagir com o grupo. Algumas vezes, ela não produz nenhuma expressão, deixando-nos a dúvida sobre se de fato nos ignora ou não entende nossos convites. Em outras, ela toca um instrumento, emite uma vocalização ou um som, o que é geralmente comemorado pela equipe. Porém, ao analisar os vídeos, podemos ver diversos momentos nos quais ela ocupa esse espaço que lhe oferecemos, mas que passam desapercebidos devido à maneira como o faz. Ao pedir que toque um instrumento na canção de despedida na sessão de 22/11/13, por exemplo, ela bate nas cordas do violão suavemente e volta a mover-se diante do espelho, de costas para o grupo. Ninguém se dá conta de que ela fez o que havíamos pedido, e o grupo insiste em solicitar dela uma resposta, o que parece aumentar a sua ansiedade.

É preciso, portanto, uma sensibilidade aguda da equipe para perceber esses eventos de interação tão sutil. Na canção de abertura da oficina do dia 29/11/13, por exemplo, ocorre uma interação entre Camila e Mathias que indica uma surpreendente conexão entre os dois. Estamos sentados em roda (Fig. 21), e Camila está deitada no centro. Mathias escolhe o pau de chuva, ou "chocalho-ampulheta", tal como ele o chama, e Camila um chocalho comum.

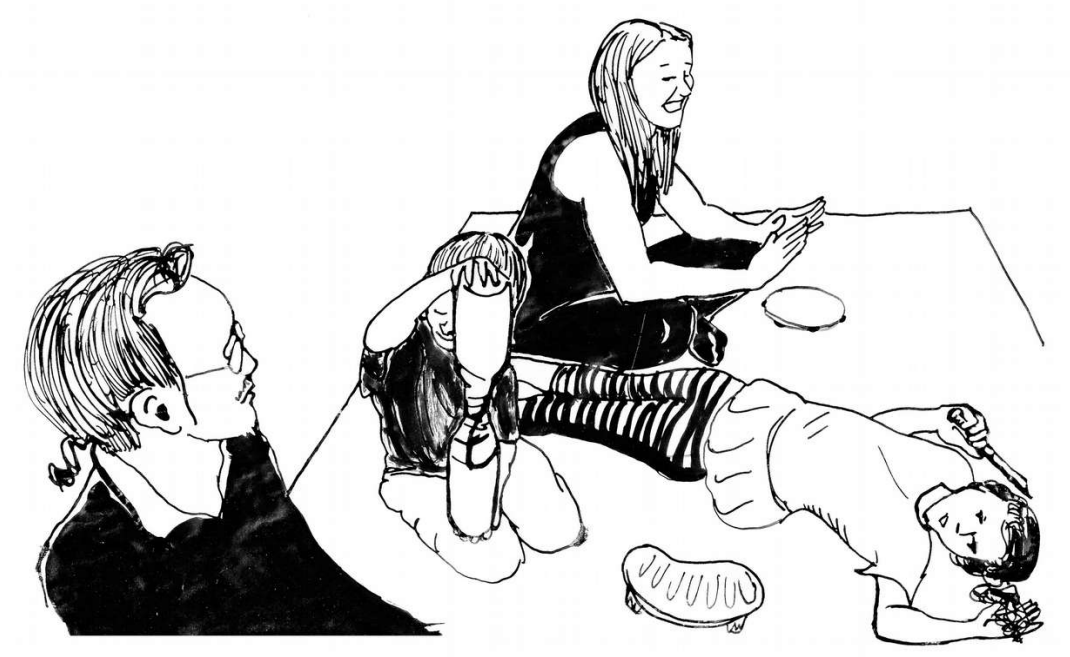

Figura 21 - Ilustração da recriação da canção de abertura da oficina de música de 29/11/13

Ambos instrumentos haviam sido construídos em uma sessão anterior. A transcrição desse segmento (Fig. 22) mostra que Camila imita e acompanha os movimentos de Mathias 
com sincronia. Ela repete com o chocalho o gesto de inclinar o instrumento e deixar as contas caírem lentamente, tal como ele faz com o pau de chuva nos primeiros compassos. Ainda não comecei a cantar e já há uma alternância entre o que um e o outro tocam, como um jogo de pergunta e resposta que se desenvolve em um ritmo bastante definido.
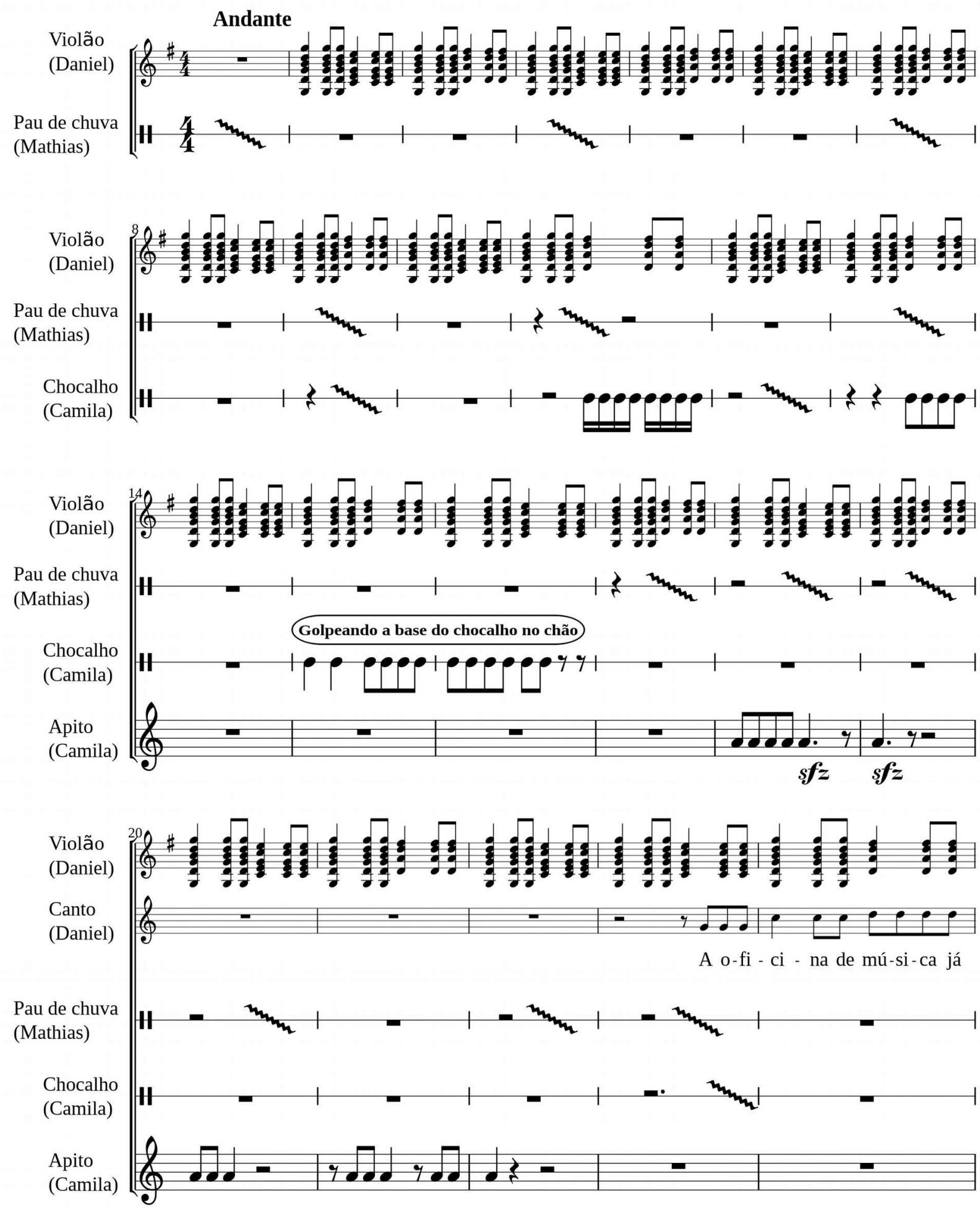

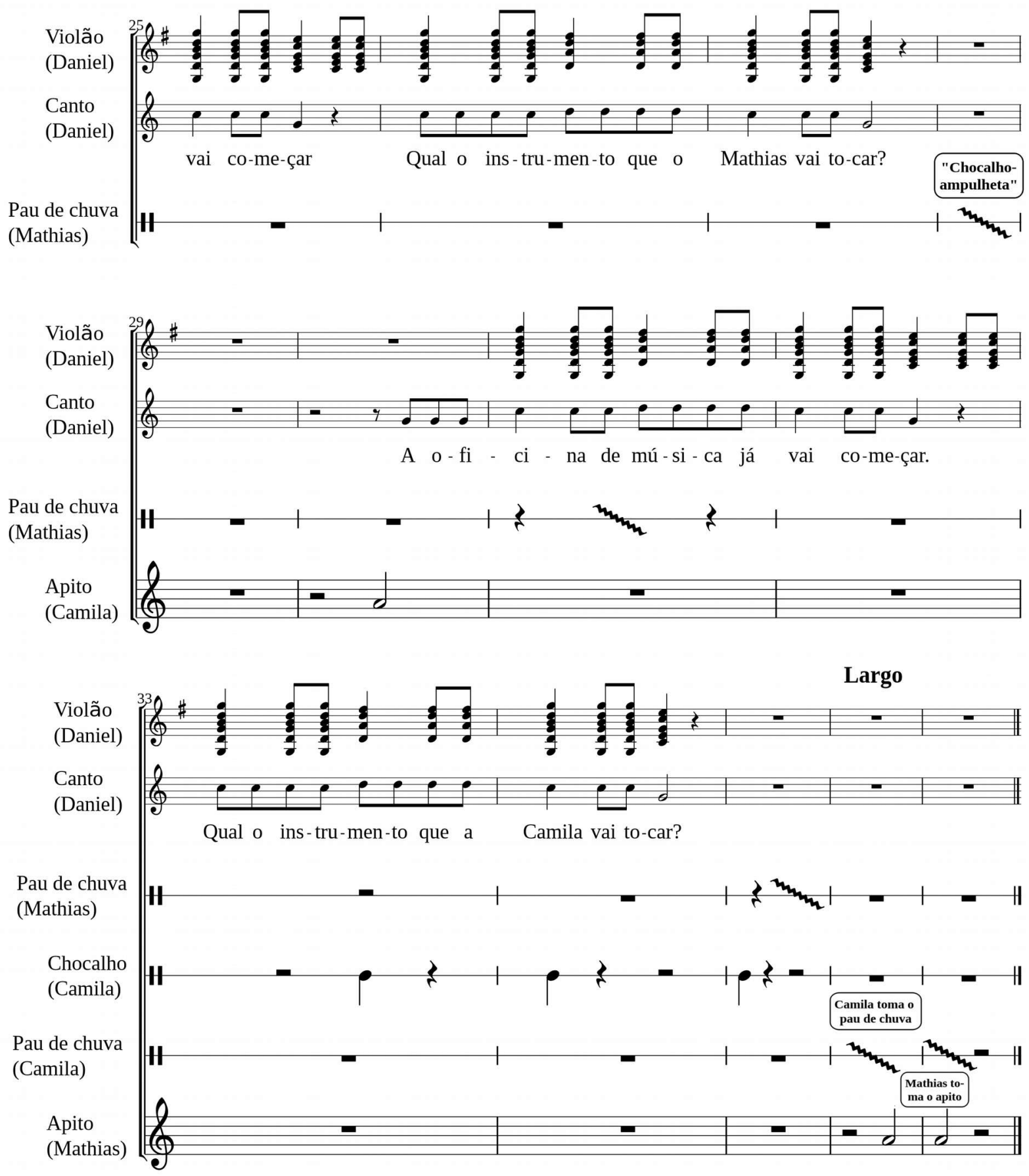

\section{LEGENDA}

= Inclinar o instrumento até que as sementes alcancem o outro lado (a duração é dada pelo tempo no compasso)

Figura 22 - Transcrição de recriação da canção de abertura da oficina de música de 29/11/13 
Eles praticamente não se cruzam, cada um ocupa o seu lugar e só começa a tocar quando o outro para. Junto com o chocalho, Camila começa a soprar um apito, que também entra na interação com o pau de chuva. Quando convoco Mathias a apresentar seu instrumento, Camila o observa com atenção. Porém, quando chega a sua vez, e ela agita o chocalho, Mathias gira novamente o pau de chuva. Ela então se levanta e agarra esse instrumento, deixando o apito em seu lugar. Mathias assume o apito, e eles tocam juntos, finalizando o segmento.

Esse momento que compartilhamos todos juntos, e no qual a interação entre Camila e Mathias permitiu uma forma de comunicação não-verbal incluindo a troca de turnos, seria inimaginável no começo do seu tratamento. É notável o modo como Camila encontrou novas formas de se relacionar conosco, superando um prejuízo severo do laço com a alteridade. Talvez a oficina de música tenha contribuído pouco a esse movimento. Porém, mesmo que ela tenha participado relativamente menos que as outras crianças, algumas das atividades que propusemos foram momentos importantes para experimentar um contato diferente com os adultos e as outras crianças. Seu avanço é algo intrigante para toda a equipe, e produz otimismo e esperança sobre as possibilidades de sua recuperação.

\subsection{Mathias}

Mathias é uma criança de 5 anos e estuda na Creche Central da Universidade de São Paulo. Sua família possui origem alemã, e a mãe relata que preferiu dar à luz naquele país por considerar o sistema de saúde melhor que o do Brasil. Durante os primeiros anos do bebê, a família mora na Alemanha, e é uma amiga da mãe que nota algo diferente em Mathias, levantando pela primeira vez a suspeita de autismo e perguntando se ele já havia sido levado a um médico. Não sabemos se essa consulta de fato ocorreu pois, apesar da creche afirmar em um relatório que ele foi diagnosticado com autismo naquele país, isso não está presente no relato da mãe, que inclusive recusa esse diagnóstico. Em casa, Mathias fala em alemão com os pais e com o irmão, dois anos mais novo, mas isso é repreendido na presença de outras pessoas, quando a mãe só permite que ele use o português.

A matrícula na creche é feita pelo pai, professor universitário, que o apresenta como tendo um problema de comunicação. Nos primeiros dias de aula, Mathias recusava o contato dos 
adultos, desviando o olhar ou ficando calado quando estes tentavam se comunicar com ele. Por sua vez, quando o menino se comunicava, ninguém o entendia, e sua escrita alternava entre o português e o alemão. Só falava na terceira pessoa, com verbos no infinitivo e no final da frase, o que levantou suspeitas de problemas com o bilinguismo. Também evitava a companhia das outras crianças, permanecendo afastado ou circulando pela creche. Chorava frequentemente e apresentava poucos momentos de brincadeira simbólica. Com o tempo, os educadores notam alguns comportamentos estranhos, como empilhar e contar cadeiras ou escrever com o giz de cera no chão os horários das atividades da semana. Há uma carga de ritualização nessas ações, e ele dificilmente as abandona, ou aceita outra atividade antes de chegar ao seu fim. Essa necessidade fica patente para mim quando o encontro pela segunda vez, lendo uma revista na sala de espera, e o convido para ir à oficina, o que ele ignora. $\mathrm{O}$ pai, sentado ao seu lado, me olha constrangido, dizendo "Agora ele só vai sair daí quando terminar a revista". É o que ocorre, de fato.

Algum tempo depois de matriculado, a creche recebe a ligação de uma psicoterapeuta que diz estar trabalhando com Mathias e que, por ter pouca experiência com crianças, pede mais informações a seu respeito. Mais tarde, descobre-se que esse tratamento havia sido curto, primeiro ocorrendo semanalmente, depois quinzenalmente, e que foi por fim interrompido. Mathias é então encaminhado pela psicóloga da creche ao Lugar de Vida, onde ele passa por uma entrevista de triagem. Aparentemente, a mãe ficou impressionada com as crianças que viu passar pela recepção, que pareciam estar muito mais doentes que seu filho. $\mathrm{Na}$ reunião em que eu apresento meu projeto de pesquisa aos pais, ela narra esse episódio. E acrescenta que, tendo em vista a facilidade de Mathias com a escrita, os números, medidas e temas científicos, ela resiste à hipótese de que seu filho seja autista, assumindo-o como um possível superdotado. Por fim, declara que o pai do menino também havia sido autista quando criança, mas que havia sido curado, o que se comprovaria pelo fato de ser agora um bem-sucedido professor. A cura do pai contrariava a informação que lhe haviam dado no Lugar de Vida, o que entendo ter sido algo decisivo para que ela desistisse do tratamento naquela instituição. É somente então que ele é encaminhado para o Núcleo de Educação Terapêutica.

Mathias começa um tratamento individual com Paula, psicóloga do núcleo, que passa a atendê-lo semanalmente. Eles rapidamente desenvolvem um vínculo por meio de jogos e de um caderno, no qual Mathias passará muito tempo escrevendo. Uma das características que surge desde o início desse atendimento é a competitividade e a necessidade de Mathias ganhar 
todos jogos propostos por Paula. Quando é ela quem ganha, é necessário repetir a partida, até que Mathias possa vencer. A vitória parece ser um elemento que lhe dá segurança, assim como as medidas, os números e os rituais rígidos. Tendo em vista que ele apresenta um desenvolvimento cognitivo excepcional para sua idade, porém uma reduzida capacidade de interação com o outro, ela indica a sua participação no grupo terapêutico.

Mathias é apresentado ao grupo três sessões após o seu início, no dia 17/05/13, sendo acompanhado por Paula. Naquele dia, "William o recebeu perguntando 'Quem é você?', ao qual Mathias respondeu repetindo 'Quem é você?'. William então começou a contar as pessoas na sala, acompanhado com interesse por Mathias" (Relato do Grupo Terapêutico, 17/05/13). Durante a primeira parte dessa sessão, Mathias se manteve sentado de costas para o grupo, porém podemos ver nas imagens do vídeo que ele canta e acompanha a música tocando o xilofone no ritmo das canções "Atirei o pau no gato" e "O pato pateta”. Essa canção tem um efeito significativo para ele, pois, logo após os primeiros versos, ele sorri e para de tocar, ficando estático por alguns momentos. Depois volta a tocar, marcando a pulsação da canção com uma nota em cada tempo, indo e voltando no teclado do instrumento.

Em seguida, anunciei que havia trazido uma outra canção da televisão, "Banho é bom", do compositor Hélio Ziskind, e famosa por ser parte da trilha sonora do programa "Castelo Rá-Tim-Bum”, no qual acompanha uma animação em stop motion de um rato que se banha. A letra narra partes do corpo enquanto elas são banhadas, e inclui um diálogo do personagem com a toalha, antes de terminar a canção:

Tchau preguiça, tchau sujeira.

Adeus cheirinho de suor.

Lava, lava, lava, Uma orelha, uma orelha, outra orelha, outra orelha.

Lava, lava, lava, lava testa, bochecha.

Lava o queixo, lava coxa e lava até meu pé, meu querido pé que me aguenta o dia inteiro.

E o meu nariz, meu pescoço, o meu tórax e o meu bumbum e também o fazedor de xixi.

Ainda não acabou não, vem cá, vem. 


\section{Uma enxugadinha, uma coçadinha ali, faz a volta e põe a roupa de enfaixar. \\ Banho é bom, banho é bom, banho é muito bom.}

\section{Agora acabou!}

Após o penúltimo verso, ele canta a coda da canção, “Agora acabou!", com uma evidente expressão de alegria. É a primeira vez em que ele gira a cabeça para trás e nos olha. Eu pergunto "Agora acabou?" e ele me confirma que sim. Proponho então repetir a canção, tocando as partes do corpo que a canção indica. Paula então o senta em seu colo, de frente para o grupo, e fazemos a coreografia apontando as partes do corpo conforme eram cantadas. Apesar de não acompanhar com destreza todos movimentos, ele põe suas mãos sobre as orelhas e os pés. Paula o levanta, sua postura é rígida, com os braços estirados para baixo. No final desta segunda repetição, de frente para o grupo, ele canta a coda novamente. Pergunto então quem ali gostava de tomar banho, e Pablo e Mathias levantam a mão. No final dessa sessão, tento fazer uma brincadeira com ele, fingindo que não encontro o pandeiro que está entre nós dois, mas não consigo que ele entre no jogo e me entregue o instrumento. Sua atenção está voltada para o violão, para o qual aponta e diz "10 centímetros". Depois ele apoia as mãos nas laterais do violão e repete novamente a medida, com uma expressão de satisfação.

A coda surgiu a partir daí como uma espécie de jogo musical que desperta o interesse de Mathias nas demais sessões da oficina. Tanto na canção "Banho é bom" quanto em "Atirei o pau no gato", é ele quem conclui a apresentação com o último verso, sempre acompanhado de expressões faciais e vocais de júbilo. Em geral, a coda não aparece imediatamente após terminar o penúltimo verso, pois Mathias parece dar uma pausa, como que conferindo-lhe uma fermata. Talvez essa expectativa da espera, imersa no silêncio, seja o que ele realmente aproveita dessas situações, onde existe uma nova configuração do tempo e da surpresa, que pode ser frustrada, quando proponho uma nova repetição em lugar de concluir, ou confirmada, quando ela realmente indica o fim da apresentação.

$\mathrm{Na}$ semana seguinte (24/05/13), Mathias já está integrado ao grupo. Ele se senta de frente para os demais e canta algumas canções, tocando e se divertindo. Trata-se de um encontro especial, pois durante o grupo da manhã, houve uma proposta de fazer uma festa de aniversário para mim. Quando entro, sou recebido com um "Feliz aniversário, Daniel”. Há uma grande emoção circulando entre todos. Começo a organizar a roda e a canção de abertura, e Mathias me dirige por alguns instantes um olhar fixo e brilhante, como se estivesse siderado 
pela minha imagem com o violão. Quando começo a tocar a canção "Banho é bom", ele me acompanha e canta, com um sorriso. $\mathrm{O}$ contato visual comigo é intermitente, e seu olhar às vezes está distante, voltado para o nada. Paula diz algo no ouvido dele, e ele começa a tocar algumas das partes do corpo que aparecem na letra, como, por exemplo, a bochecha (Fig. 23)

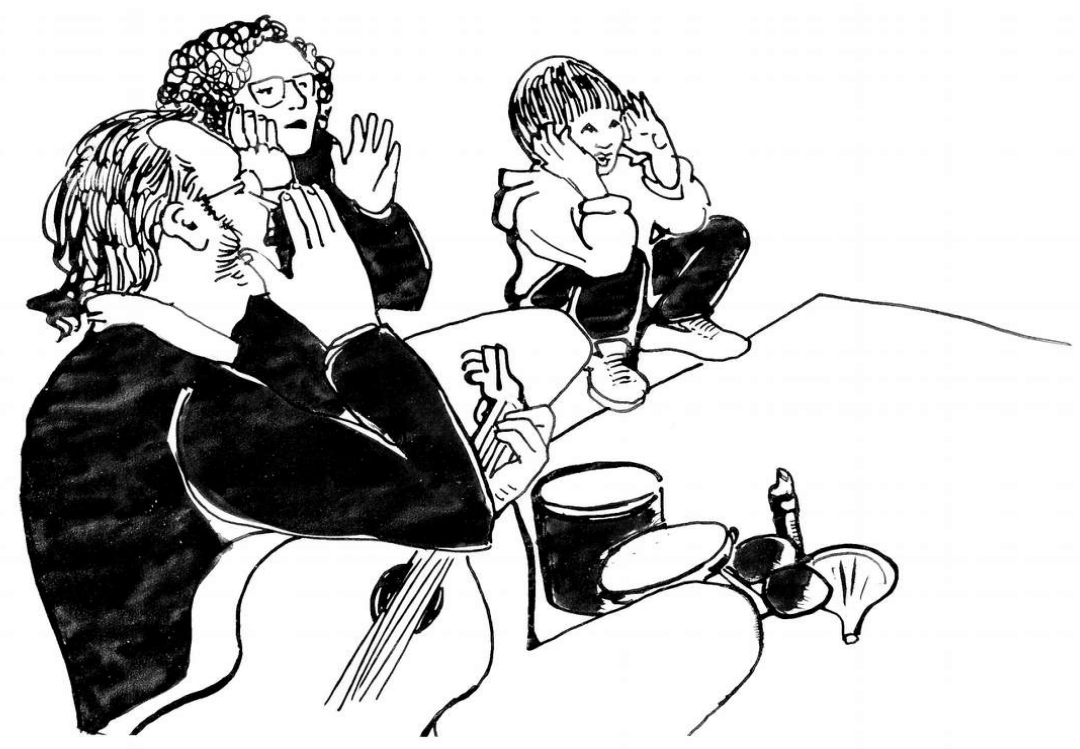

Figura 23 - Ilustração de coreografia da canção "Banho é bom" na oficina de música de 24/05/13

Percebo que a posição dele é incômoda, com os joelhos flexionados de cócoras. De fato, uma de nossas preocupações constantes é com sua postura, pois ele permanece por longos períodos ajoelhado ou sentado com as pernas para trás em W, se não pedimos que ele se sente de outra maneira. Assim, na hora em que canto o verso "Meu pé, meu querido pé que me aguenta o dia inteiro", jogo meus pés para cima, e pedalo no ar, o que é acompanhado por Paula e Juliana, mas não por Mathias, que está sentado entre as duas. Ele nos olha com uma expressão de surpresa, parecendo não entender o que estamos fazendo. Quando a canção termina, há um silêncio prolongado, e ele me olha e sorri. Antes de cantar a coda, ainda há tempo para olhar ao redor, e depois de dizer "Agora acabou", ele bate palmas e mostra um grande sorriso de satisfação.

Em seguida, Juliana propõe uma ciranda, lembrando que Sofia havia pedido que dançássemos. Era também uma forma de trazê-la de volta à sala, depois de haver saído quando um chocalho jogado para cima por William a atingiu na cabeça. Como Sofia topa voltar, nos reunimos de pé e pedimos que ela nos ensine uma coreografia (Fig. 24). Ela pede que nos organizemos em duplas e nos mostra alguns passos, com giros alternados e simultâneos dos parceiros. Apesar de Mathias e Paulo imitarem alguns dos passos, há um atraso com relação à execução 
do resto das duplas, e é Paula quem faz com que alguns movimentos sejam executados (b, i). Podemos notar que, em alguns momentos, Mathias apenas observa enquanto os demais realizam os passos $(d, f, h)$, e tem uma dificuldade em reproduzi-los simetricamente, sobretudo quando se trata do cruzamento de pernas (e). Ele imita o passo, mas sem orientá-lo para a sua

a)

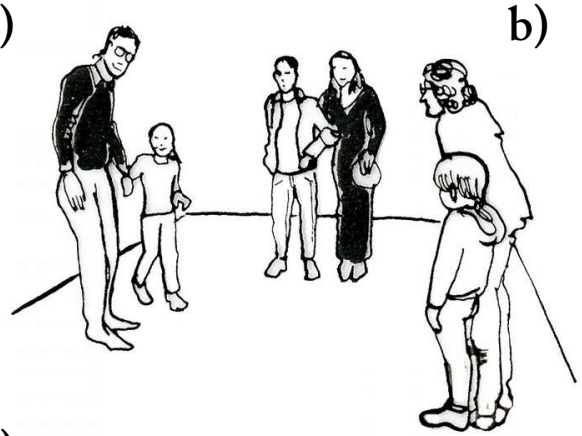

c)

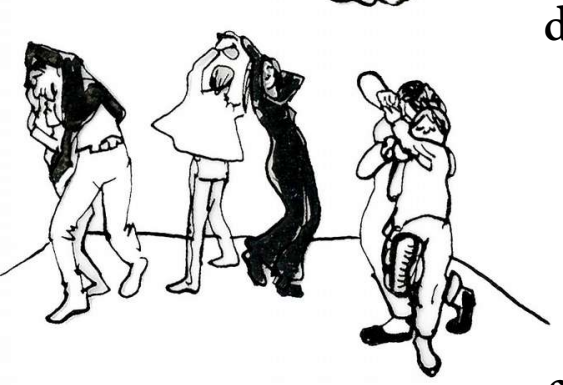

e)

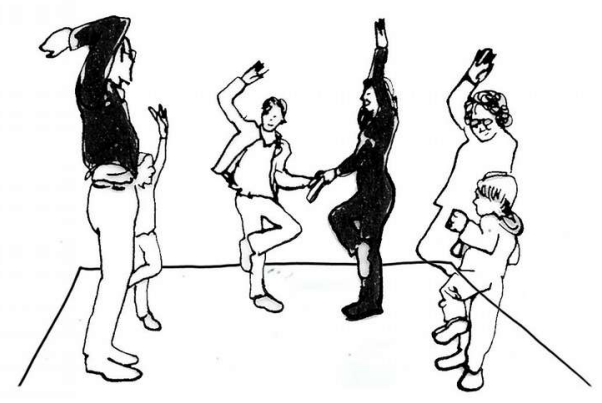

g)

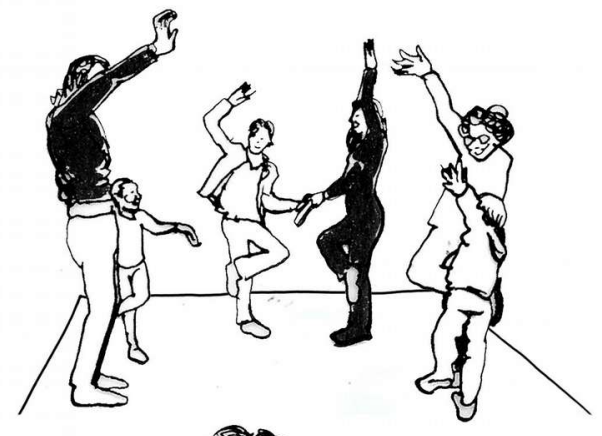

i)

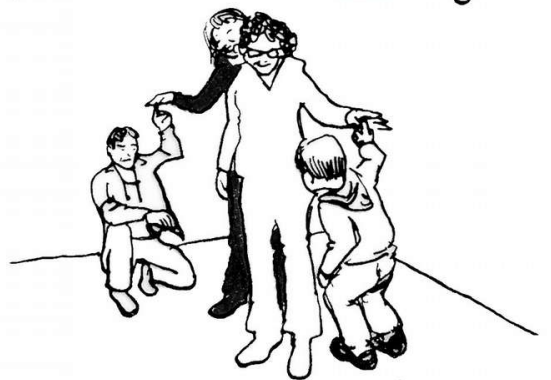

f)

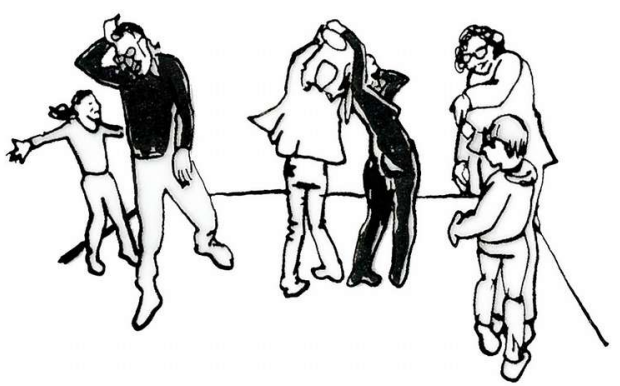

d)
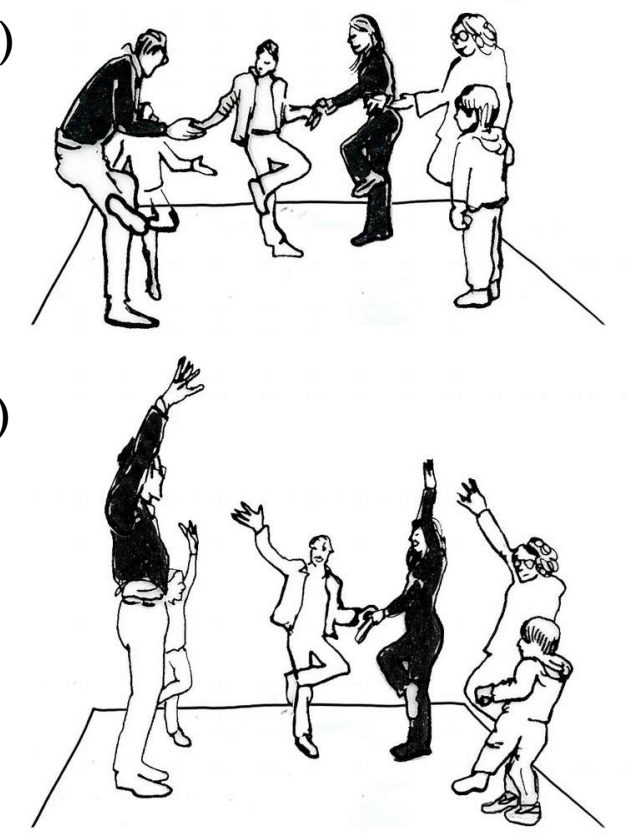

h)

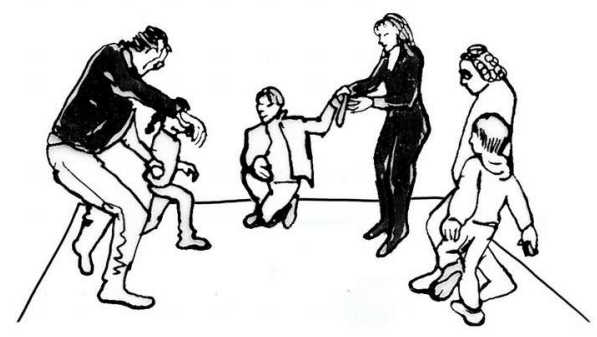

j)

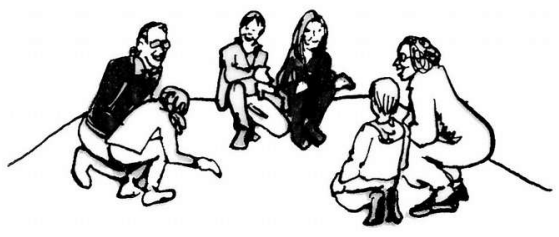

Figura 24 - Ilustrações de coreografia na oficina de música de 24/05/13 
perspectiva. No final da coreografia, todos nos ajoelhamos no chão, e Mathias e Paula também se juntam ao resto das duplas. Após esse desfecho, fazemos uma ciranda, que termina também com todos indo ao chão. É possível perceber, no entanto, que Mathias não acompanha o ritmo do grupo, e só se joga no chão após um atraso com relação aos demais, ainda que este intervalo seja menor que o da dança anterior (Fig. 25)

a)

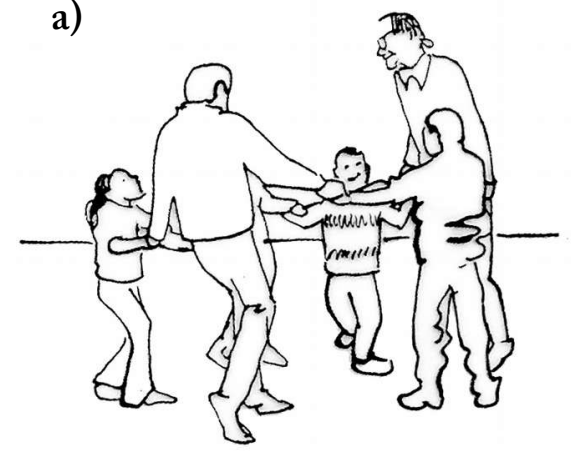

b)

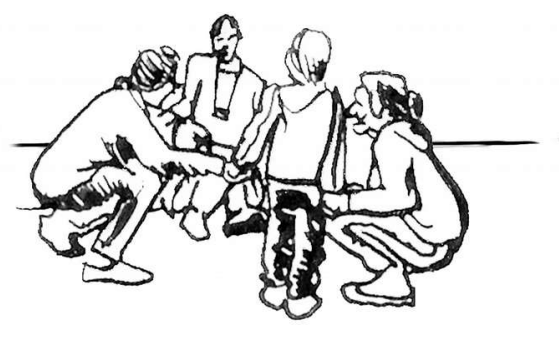

c)

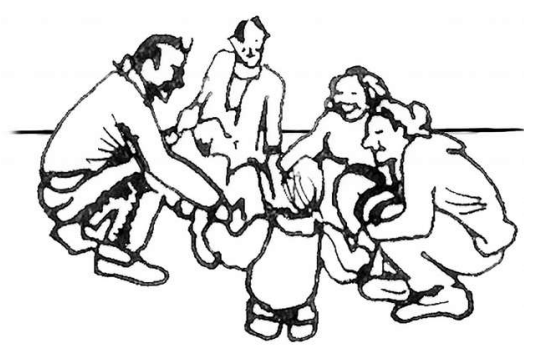

Figura 25 - Ilustração de coreografia de ciranda na oficina de música de 24/05/13

Muitas vezes somos os adultos quem precisamos intervir de alguma forma para incluir as crianças na brincadeira. É possível aí facilitar a sua interação com os demais, mesmo quando lhes é difícil ou impossível participar de uma ação conjunta com o grupo. Em 08/09/13, por exemplo, estamos brincando sobre a figura melódica da trilha sonora do filme "Tubarão", por sugestão de William, e levamos as mãos acima da cabeça, representando a barbatana do animal (Fig. 26). Mathias não nos imita, e tento um contato ocular para tentar motivá-lo (a). Sem saber se ele vai adotar o movimento ou não, decido levar a minha mão à sua cabeça e faço o ges to por ele (b). Ele se abaixa um pouco com o meu toque, mas deixa a minha mão ali por alguns instantes, tempo no qual ele está participando da brincadeira e chama a atenção dos demais, mesmo que com o meu auxílio.

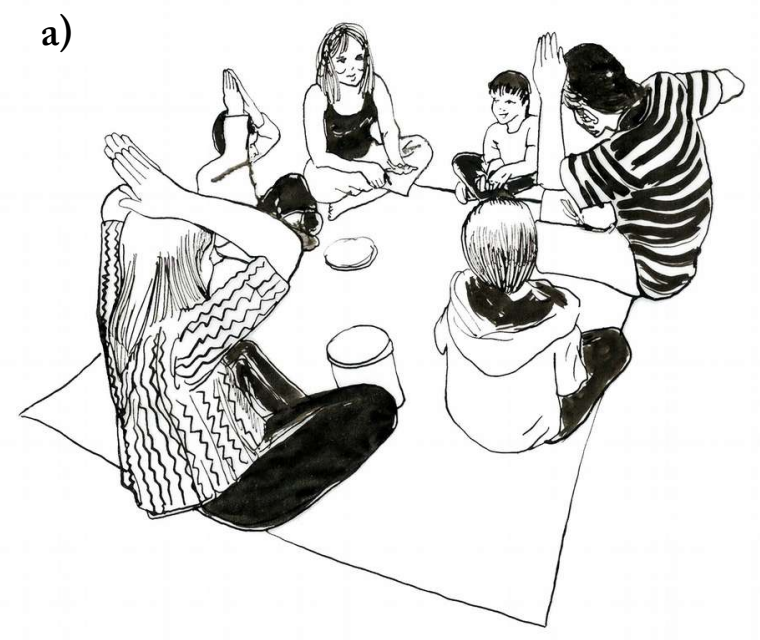

b)

Figura 26 - Ilustrações de coreografia sobre tema do filme “Tubarão" na oficina de música de 08/09/13 
Esse tempo diferido, que é uma marca da interação de Mathias com o outro e que vemos como um atraso, é um dos aspectos mais intrigantes do trabalho com ele. Apesar de acompanhar sem dificuldade o ritmo dos instrumentos quando tocamos e cantamos, quando se trata dos movimentos e gestos corporais, ele não apresenta a mesma habilidade. São diversas as vezes em que sinto que ele não entende o motivo pelo qual nos jogamos no chão, tocamos as partes do corpo com as mãos ou brincamos de bater palmas alternadas com golpes nas coxas. Apesar de tudo, ele ainda por vezes nos acompanha, mesmo que tenha que ter o seu tempo para fazê-lo, ou que outras vezes permaneça distante, com o olhar escapando do nosso. Quando dançamos juntos, sua expressão no entretempo entre a percepção da ação do outro e a sua própria parece ser menos de indiferença que de surpresa e interesse, como se ele nos estudasse para decidir o que fazer. Essa regulação temporal estendida, no entanto, prejudica o seu ritmo, pois ele muitas vezes está completamente fora do pulso que os demais compartilham.

O tempo, de fato, parece ser um aspecto central na compreensão da sua experiência conosco. Durante as sessões, Mathias frequentemente diz a duração das cancões após terminarmos. As medidas nunca são as das durações reais, o que nos deixa uma dúvida sobre o quanto elas se referem menos a um tempo externo que a um interno. De maneira inesperada, mas na esteira dessa reflexão, na sessão de 16/08/13, surge a "Música do relógio", que nos dá algumas pistas sobre a relação de Mathias com o tempo medido. Em uma improvisação na qual estamos brincando com a marcação de uma pulsação, Pablo repete o som do ponteiro dos segundos "tic-tac, tic-tac". Aproveito a iniciativa pedindo que os demais acompanhem e, quando sinto que estamos no mesmo pulso, aviso que havia deixado o alarme programado para aquela hora, fazendo um sonoro "trrrrrrr", levando o grupo a rir. Volto a repetir o "tic-tac" e proponho que cada um faça o seu próprio alarme, alternando-nos em sentido horário. É preciso uma negociação implícita para ver quando esse tutti termina e a pessoa da vez revela o seu solo de despertador, mas é uma grande surpresa quando chega a vez de Mathias. Enquanto todos permanecemos parados e cantamos ou tocamos sons simples, ele grita e agita a cabeça, as mãos e os braços com espasmos violentos, dando fortes golpes em glisandi no xilofone. A agitação motora dura alguns instantes até que ele para e me olha, ofegante e corado, mas com um largo sorriso na boca.

Durante varias sessões, Mathias passa longos momentos voltado para o relógio enquanto tocamos, frequentemente só tirando o olhar dos ponteiros quando terminamos de cantar, o que representa um entrave para que participe de algumas atividades com o grupo. Proponho 
então que ele se sente de costas para o relógio, como uma forma de intervenção, na sessão do dia 20/09/13. Ele só comenta uma vez a duração da canção nesse dia, mas curiosamente pede a "Música do relógio" depois de cantarmos a canção de encerramento. Sua performance do alarme é a mesma que da outra vez, explosiva, ruidosa e descontrolada, tanto sonora quanto corporalmente.

À imagem do menino tranquilo e silencioso, que permanece imóvel e distante enquanto as outras crianças se agitam e correm, soma-se uma faceta violenta e exaltada. A performance do alarme representa uma descarga energética muito maior do que aquela com a qual talvez já nos havíamos acostumado, como as codas festivas e alegres, onde ele sorria e saltava. Esse aspecto é discutido em uma reunião clínica com a equipe do Lugar de Vida, na qual levantamos a hipótese de que uma extrema desorganização psíquica demandasse dele uma rigidez equivalente, porém não suficiente para evitar os desbordamentos apresentados. Pensamos algumas situações em que isso ocorre e conto que, na semana anterior, depois de terminar a oficina e levar as crianças para seus pais na sala de espera, Mathias vai até um calendário pendurado na parede e passa os dedos sobre os números, contando-os. Me dirijo até ele e tento perguntar-lhe algo, mas ele não interrompe a sua contagem e tampouco me responde. Pergunto então o seu número favorito. Sem obter resposta, pergunto à sua mãe, que se aproxima com o irmão mais novo de Mathias, o número favorito dela. Conto o meu favorito também e Mathias segue atento ao calendário, só parando com uma grande insistência da mãe. Pergunto novamente o seu número favorito e ele fala, em um tom áspero, “22.532”. Penso o quanto há uma pressão externa para que ele seja uma criança normal ou, mais do que isso, que desenvolva suas capacidades cognitivas, seu interesse científico e a capacidade com os números e as letras, apesar de seu isolamento dos demais. Quanta importância podem ter esses excessos que ocorrem na oficina, enquanto possibilidades de experimentar um impulso que o mobilize e lhe encha de vida? Qual a relevância de que isso ocorra em uma estrutura clínica e musical? Outra discussão é a dificuldade em dar um ponto final àquelas atividades pelas quais Mathias parece ser dominado, sem escapatória. São as coisas que terminam, e não ele quem lhes dá o final. Isso é pensado também em conexão com a comunicação, que muitas vezes é um fluxo ininterrupto de palavras, sem articulação e, portanto, sem sentido. É um discurso que dá a impressão de um código estruturado sem mensagem, que o outro vê desenrolar-se sem poder compreender.

Uma das direções de tratamento que são debatidas na reunião no Lugar de Vida é o estabelecimento de condições para que Mathias forme laços com as outras crianças, que condu- 
zam a processos de identificação com os demais. William parece ocupar esse lugar muitas vezes, por exemplo, nas imitações que Mathias faz de jogar os instrumentos para o alto ou subir nas mesas para saltar. Os excessos e a agitação de William certamente o contagiam e o vitalizam, ainda que seja difícil ver os dois realmente se engajando em uma atividade juntos, sendo mais comum que Mathias o imite de longe ou em um tempo diferido. Por outro lado, algumas intervenções destinadas a Mathias buscam incidir nesse aspecto temporal do engajamento das ações com os gestos do outro, ao mesmo tempo em que atuam sobre a modulação da excitação corporal e promovem o laço social. "Banho é bom" constitui uma ferramenta terapêutica importante no trabalho com ele, tanto porque desperta desde o princípio o seu interesse e marca as suas primeiras interações conosco, quanto porque ele progressivamente incorpora os seus gestos, e claramente melhora a sua performance, encontrando um ápice de energia na coda final. Contudo, um elemento importante para alcançar essa regulação temporal e motora é a atitude do outro em convidá-lo e conduzi-lo nessas atividades coordenadas, dando-lhe a mão para formar uma ciranda ou transmitindo-lhe o gesto de um passo na dança.

Esse movimento em direção aos convites do outro não ocorre apenas com os adultos, e é com o tempo incorporado na sua relação com as outras crianças. Na sessão do dia 20/09/13, por exemplo, encontro a entrada da sala obstruída por uma trama de barbantes que estão amarrados nas mesas, produto de uma brincadeira que havia ocorrido mais cedo. Quando já estamos todos sentados e prontos para começar a oficina, Sofia se levanta e se embrenha entre os fios, perguntando "Quem poderá me salvar?". Apesar de William entrar na brincadeira, Sofia recusa a sua ajuda, deixando claro que era eu é quem deveria socorrê-la. No entanto, com a desculpa de que seria o músico da história, digo que precisamos de um herói e que é necessário encontrar um para salvá-la da armadilha. Beatriz sugere então que Mathias represente esse personagem, e ele, que estava tocando a flauta enquanto observava a situação com atenção e distância, parte na direção de Sofia, saltando desajeitadamente alguns fios, levantando outros para que ela passe por baixo.

Podemos ver que há uma mudança qualitativa e de complexidade nessa relação de acompanhamento dos gestos do outro conforme vamos chegando a nossos últimos encontros. $\mathrm{Na}$ sessão do dia 29/11/13, após termos cantado “O gato folgado”, em continuação da canção "O pato pateta”, Sofia e Pablo estão repetidamente subindo e saltando de uma pilha de colchonetes, que tem um pouco menos que a sua altura e exige um esforço considerável de braços e pernas, enquanto alternam gritos de “miau, miau!". Quando a brincadeira começa a ficar mais agi- 
tada, esses gritos chamam a atenção de Mathias, que se levanta e se junta aos dois. É um movimento incomum, geralmente ele permanece na roda enquanto as outras crianças saem correndo ou brincam ao nosso redor. A alegria que os três compartilham naquela movimentação livre e espontânea, desfazendo a pilha de colchões enquanto escorregam e desfrutam da polifonia de miados, toma-os por completo e é contagiante até mesmo para os adultos, que deixamos de apenas olhar e nos levantamos também, sorrindo. É claro que logo surge a preocupação por algum deles se machucar, e tentamos contê-los um pouco, pedindo que tenham cuidado ou indicando os melhores apoios para descer. Isso não impede que Mathias empurre Pablo e saia gritando pela sala. A agitação dele parece ser ainda mais descontrolada que a dos demais, seus gestos são desastrados e ele parece prestes a tropeçar. Pablo se levanta e parece não ter se machucado, e sai correndo atrás de Mathias. Penso que uma canção com ritmo acelerado pode ser um meio de dar forma a toda aquela energia e proponho que dancemos "Cocoricó" (Fig. 27). Sofia se joga dos colchonetes e se lança nos braços de Thales, enquanto Pablo e Mathias dãose as mãos e giram um ao redor do outro (a). No final da última estrofe, digo que vamos repetir a canção "bem baixinho", e todos se ajoelham (b) por aproximadamente três compassos.

É nesse momento que os passos de cada uma das duplas se tornam mais claramente distintos. Pablo conduz os gestos de Mathias, erguendo-lhe um braço (c), depois o outro (d) e depois os dois ao mesmo tempo (e). É evidente que é Pablo quem exerce uma força sobre os membros de Mathias, que parece quase um boneco articulado, nitidamente feliz em estar dançando. Pablo bate palmas com as mãos de Mathias no ritmo em que toco o violão, e em um momento as golpeia contra as bochechas do seu par, o que parece assustar um pouco Mathias e lhe tira o sorriso. Enquanto isso, os passos de Sofia e Thales apresentam uma notável sincronia. Apesar de a longitude de seus movimentos ser um pouco exacerbada (f), eles se movem de uma maneira bastante organizada, sem que um dos dois pareça conduzir o outro.

Seus giros e piruetas se desenvolvem no espaço com uma fluidez que claramente não é a característica dos gestos truncados e esforçados de Pablo e William. Estes, por sua vez, se separam depois de um último gesto juntos, erguendo as duas mãos para o alto (f). Pablo sai correndo em direção à outra dupla, enquanto Mathias conserva a posição com os braços esticados e passa a saltar, usando um esforço razoável e atingindo certa altura. É Beatriz, que esteve fora da roda durante todo esse tempo acompanhando o ritmo da canção com palmas, quem o conduz até o recém-formado trio e todos começam a girar em uma ciranda. Aumento ainda mais 
a)

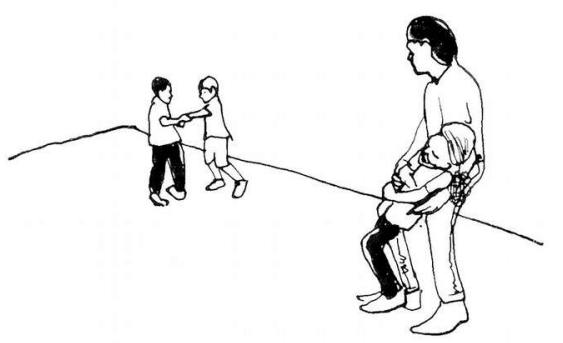

c)

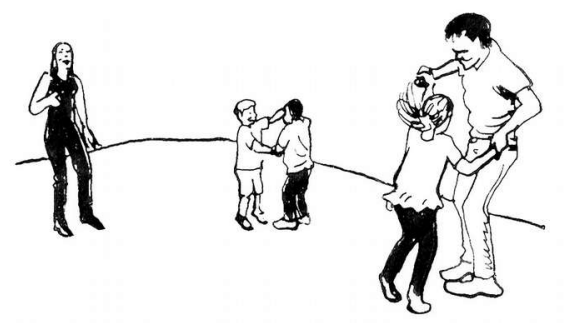

e)

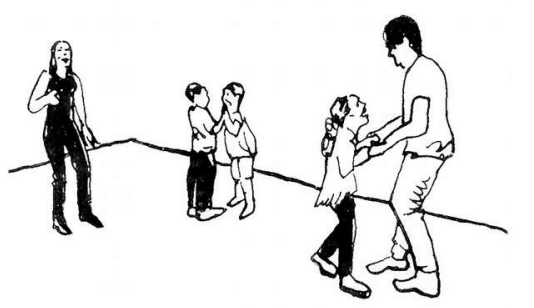

g)

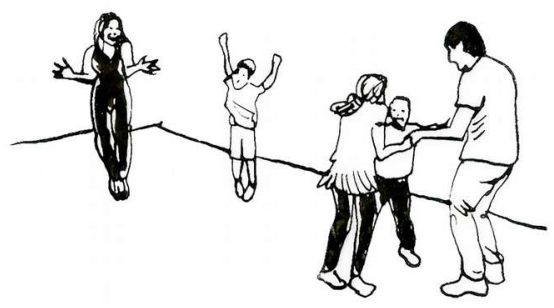

i)

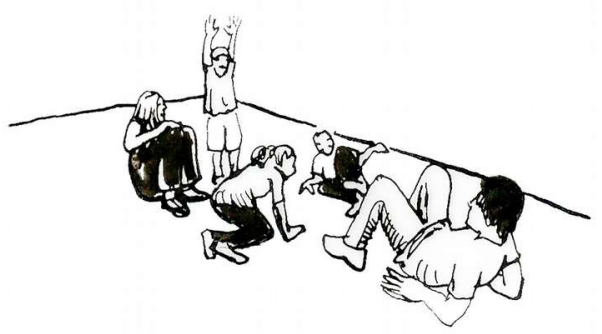

b)

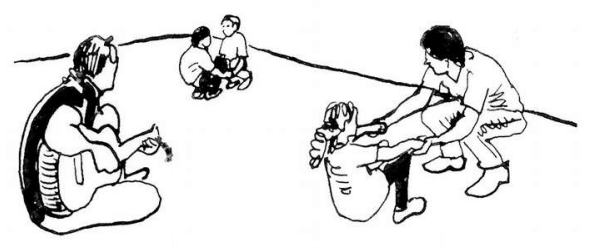

d)

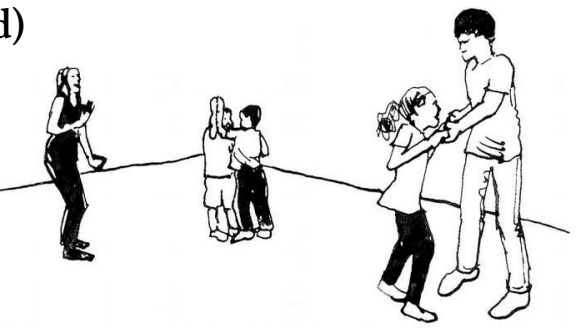

f)

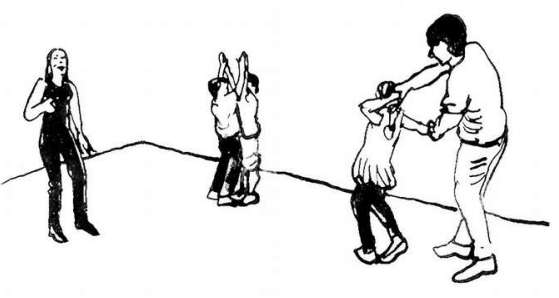

h)

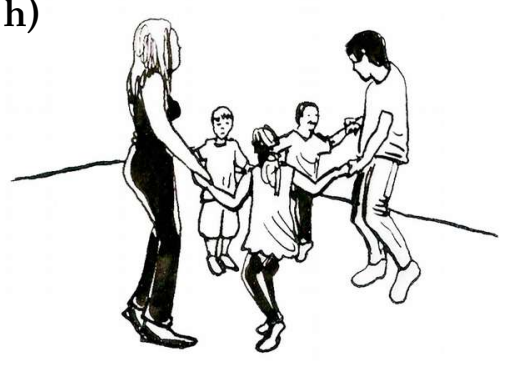

j)

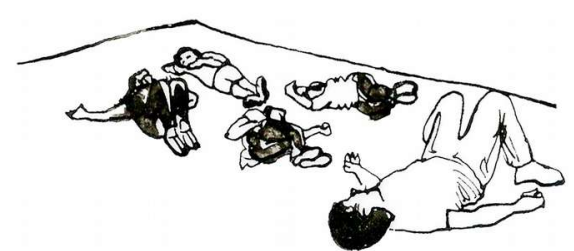

Figura 27 - Ilustrações da coreografia da canção “Cocoricó” na oficina de música de 29/11/13

o andamento e eles giram mais rápido, até que encontramos um clímax que nos faz terminar todos juntos, música e dança, e nos jogamos no chão (i). Mathias ainda permanece um instante em pé, mas se une aos demais (j). Um último detalhe pode ser levado em consideração: no final, todos permanecem com os joelhos flexionados, seja estando deitados de lado ou com a cabeça para cima. Apenas Mathias estica as pernas, cruzando os braços sobre o peito.

Assim como William, Mathias demonstrou em diversos momentos o emprego de um voz com qualidades distintas daquelas que usualmente escutamos. A modo de exemplo, apre- 
sentamos uma vocalização na sessão de 24/05/13. Naquele dia, aproveito o tema da festa do aniversário surpresa e pergunto para Mathias: “Quantos anos você tem?”. Ele me responde de forma ecolálica: “Quantos anos você tem?”. Digo a ele minha idade e ele passa a perguntar a idade dos demais. Depois, vai até a janela e olha para a persiana, tocando-a. Thales, com a câmera, se aproxima dele e pergunta a sua idade, mas ele fica em silêncio e sorri. Thales sugere que Mathias não quer dizer a idade, mas ele sai do silêncio e diz uma frase longa e ininteligível, com as palavras unidas e pronunciadas quase que silabicamente. Toda a frase parece ser pronunciada por outra pessoa, pois o ritmo e a melodia não são os mesmo que os que ele cos tuma empregar. A única parte que entendemos é algo como "[...] faltam quarenta e quatro dias". Paula pergunta: "Faltam quarenta e quatro dias para o que?". "Para chegar o junho", diz Mathias, “o 31 de junho”. Guilherme então pergunta: "Quantos anos você vai fazer em 31 de junho?", mas Mathias volta a falar algo incompreensível, com o mesmo ritmo e elisão entre as sílabas. Ele parece estar com uma agitação crescente, como se o tema o estivesse excitando, dirige-se até a porta e volta. Com os dedos da mão direita segurando a outra mão fechada ele diz uma última frase, cuja análise espectral é apresentada na figura 28. Como a primeira palavra coincidiu com o som da porta se fechando, preferiu-se omiti-la da análise, indicando-a entre colchetes abaixo do gráfico.
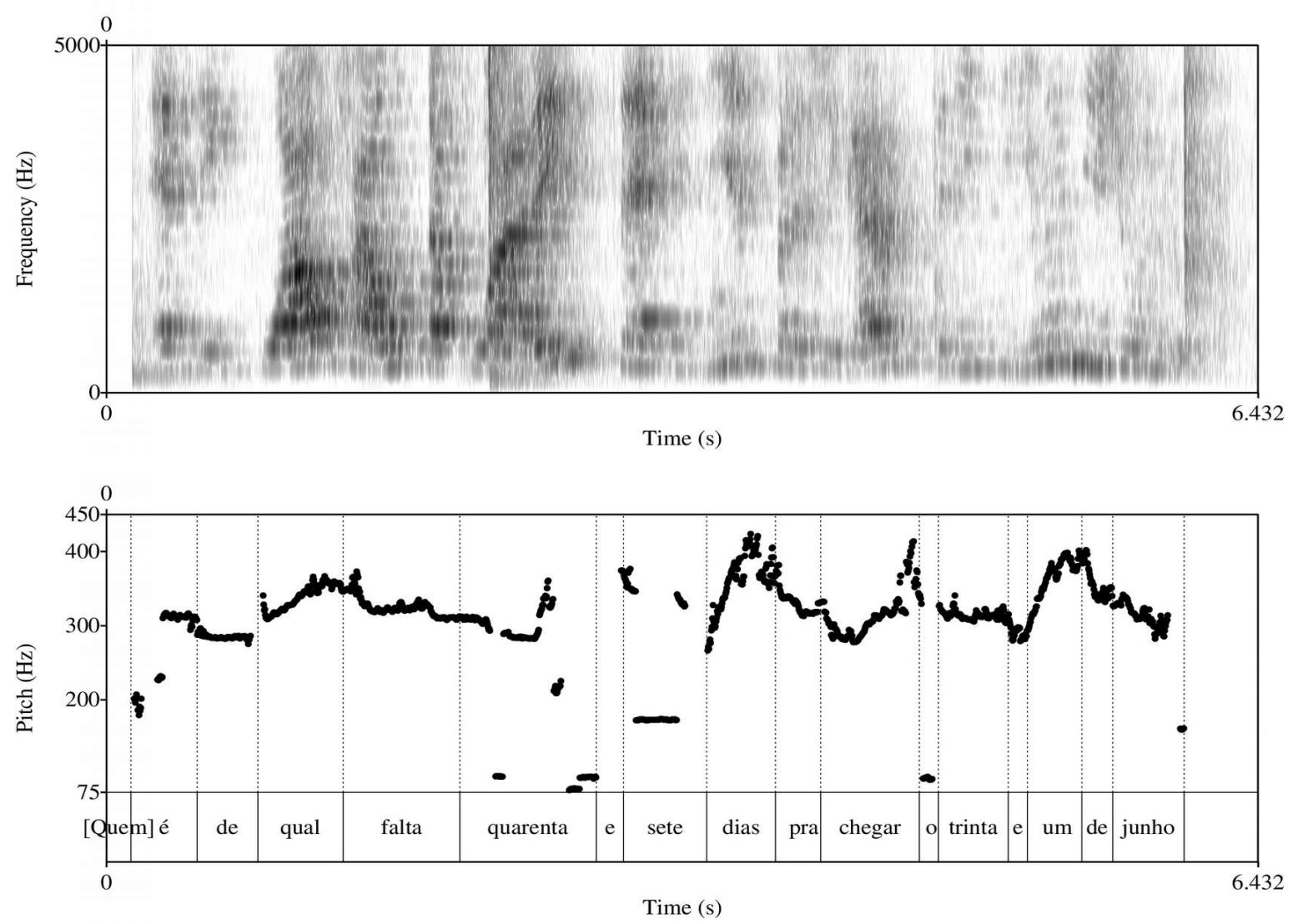

Figura 28 - Análise espectral e de pitch de vocalização de Mathias na oficina de música de 24/05/13 
Com ajuda do espectrograma, é possível perceber que essa vocalização de Mathias possui uma característica melódica peculiar, com contornos melódicos acentuados, na forma de picos prosódicos. Podemos notar também que as palavras são emendadas uma na outra, sem uma pausa que as separe. São essas características que identificamos como um "canto" diferente, ou mesmo uma "outra voz".

Aos poucos, Mathias desenvolve um vínculo com os adultos e crianças do grupo. Desde o começo da sua participação, ele demonstra um interesse em mim, dirigindo-me o olhar e sorrindo. Esse interesse assume a forma de um bilhete, que ele escreve no atendimento individual com Paula e me entrega antes da sessão do dia 28/06/13 (Fig. 29). Peço que ele leia comigo, para saber o conteúdo do bilhete. Ele o lê em um ritmo pausado, que se acelera na medida em que avança pelas frases. Ao final, ele me entrega o papel, mas parece tomado por uma excitação nervosa, com um sorriso no rosto e os olhos vidrados em algum ponto, agitando as mãos em movimentos de abrir e fechar os dedos sobre a palma das mãos. Agradeço a ele pelo bilhete e digo que gostei bastante, convidando-o a ir para a oficina.

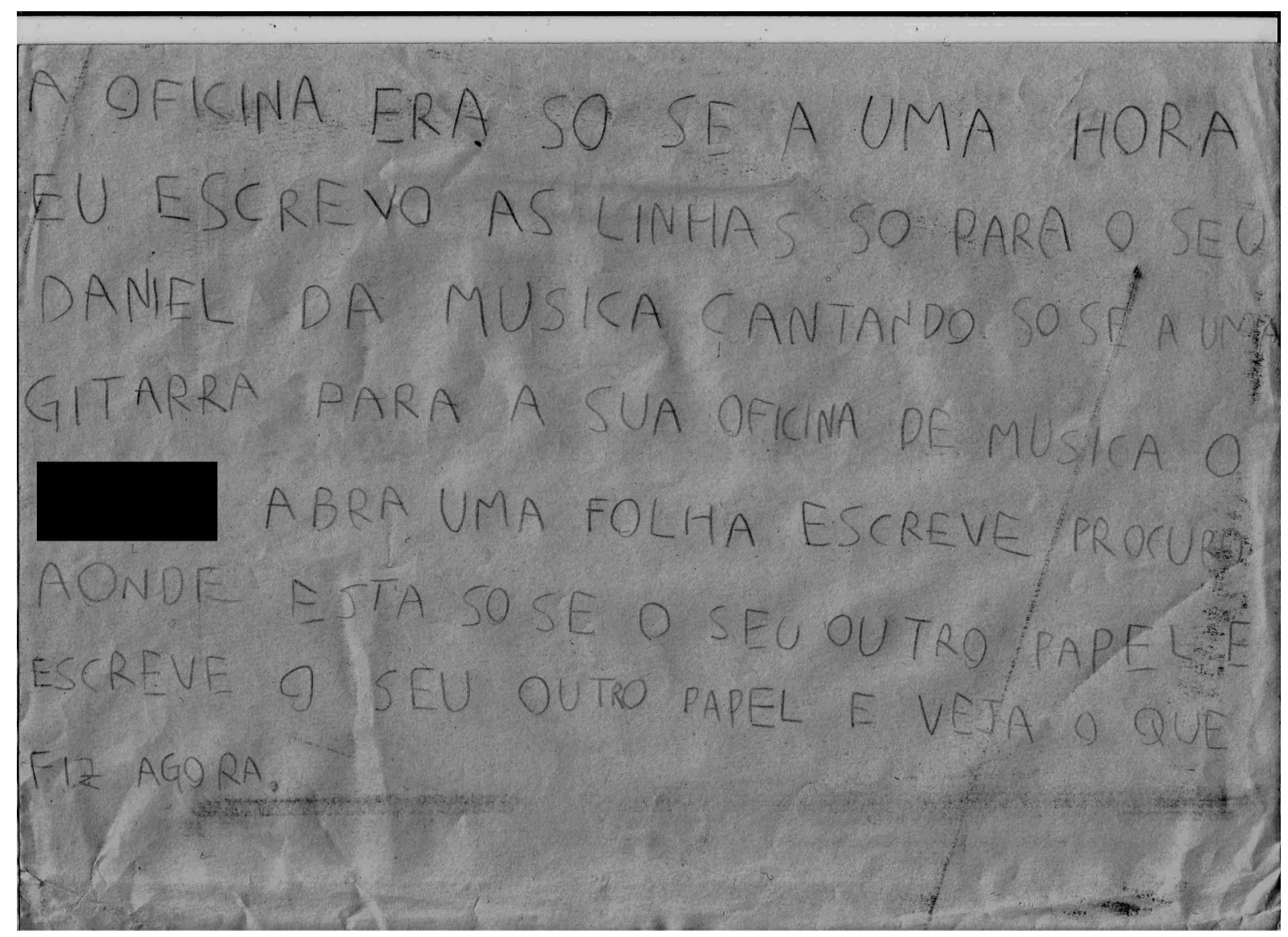




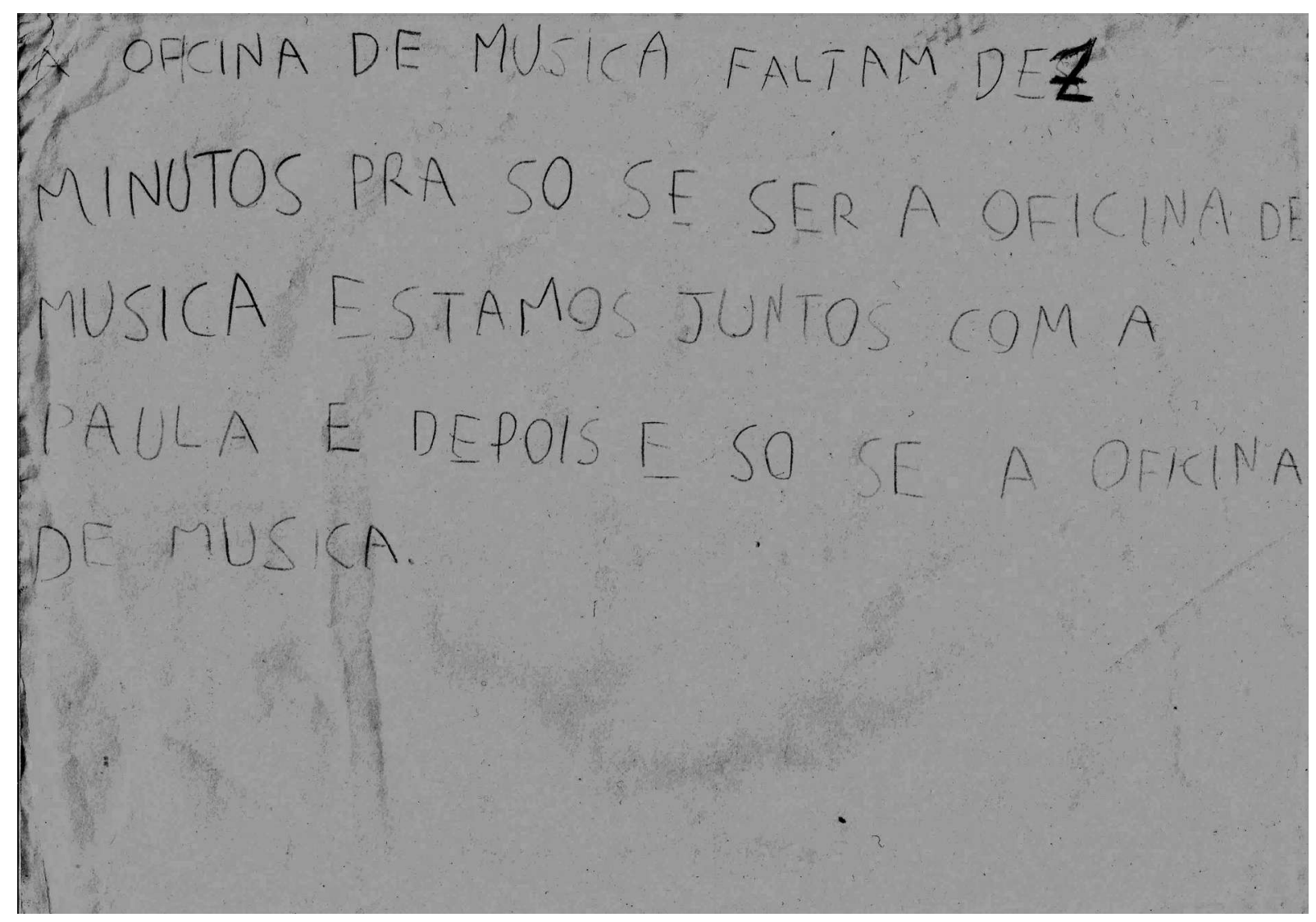

Figura 29 - Carta escrita por Mathias no atendimento individual

A carta que Mathias me entrega revela uma série de detalhes sobre ele e sua relação com a oficina. Há uma preocupação com relação ao horário em que ela começa e dura, mas de uma maneira geral entendo que há um interesse e um desejo seu em participar. Chama a atenção a maneira como ele se refere a si mesmo tanto pelo nome quanto pelo pronome pessoal, além da repetição do condicional, “só se”. No entanto, o detalhe que mais me impressiona são os comprimentos das frases, sem vírgulas e apenas com um ponto no final de cada folha. É justamente esse estilo que nos faz pensar na ideia de uma máquina significante que produz um código sem mensagem. Tal característica me faz pensar no uso que ele faz das codas nas canções, sempre estendendo-as até onde é possível, irrompendo em uma descarga motora que se traduz em um sorriso, um grito, um salto.

O final das coisas é um problema que se constitui como um dos mais importantes a serem tratados na oficina. $\mathrm{Na}$ sessão de 31/10/13, por exemplo, a ausência de um final mostrou ser desconcertante para Mathias. Naquele dia, Beatriz participou de um evento científico e não pôde coordenar o grupo da manhã. Nos organizamos para fazer um atividade de construção de instrumentos de sucata durante o primeiro horário e a oficina no segundo momento. Levei uma quantidade de materiais, como garrafas PET, cabos de vassoura, grãos de feijão e arroz, 
etc. para montar chocalhos e outros instrumentos. No entanto, o interesse de Mathias é rapidamente atraído pelo rolo de barbante, que ele começa a desenrolar, acumulando os fios em um amontoado em cima da mesa. Apesar de todas as iniciativas dos adultos em convidá-lo a montar um instrumento, fica evidente para nós que ele só poderá fazer qualquer coisa quando terminar de desenrolar todo o rolo. Ocorre aí uma intervenção a partir de uma ideia de William, de fazer uma festa de Halloween, data que seria comemorada no dia seguinte. É essa proposta que permite dar um sentido ao emaranhado de fios, que se transformam em uma decoração de dia das bruxas, representando uma teia de aranha. É difícil coordenar a montagem dos chocalhos de Pablo e Sofia, ao mesmo tempo em que Mathias e William correm ao redor da mesa com o barbante e armam uma teia de aranha que termina por envolver a todos. Ao terminar de desenrolar o último pedaço do barbante, contudo, o trabalho passa a ser o de limpar a sala para dar início à oficina, e Mathias termina sem poder construir seu instrumento.

O fim que Mathias ainda tem dificuldade em produzir parece ser uma metáfora do caráter inconclusivo do trabalho clínico com ele quando termina o ano. Uma reunião é organizada com a psicóloga e a estagiária de psicologia da creche, que apesar de não atuar no sentido de um acompanhamento terapêutico, dirige a ele uma atenção e um olhar especial. Elas nos informam que algumas mudanças são nítidas na relação de Mathias com os adultos e as demais crianças. Os professores agora conseguem contatá-lo, muitas vezes de uma maneira afetuosa, inclusive com abraços. As interações com os demais são mais fáceis e espontâneas, e ele não desvia o olhar quando lhe dirigem a palavra. Da mesma forma, ele passa a brincar frequentemente com as outras crianças, o que indica que algo do nosso trabalho pode ter contribuído para um desenvolvimento de seus laços sociais. É o momento de encerramento de um ciclo educativo, já que terminam as aulas na creche e ele começa a escola primária no próximo ano. Nossa expectativa é que ele possa usar as capacidades sociais que desenvolveu conosco em seus relacionamentos. Talvez, apesar de suas dificuldades em acompanhar as fantasias dos demais, ele possa agora desenvolver um novo modo de regular o ritmo e o andamento de suas interações. Quem sabe assim, sem deixar suas habilidades cognitivas excepcionais e seu interesse científico de lado, ele possa aproveitar esse momento como os seus pares, brincando e se divertindo. Sendo, enfim, uma criança. 


\section{DISCUSSÃO}

Apresentamos a seguir a discussão sobre alguns pontos destacados dos resultados da pesquisa empírica e dos dados obtidos pelo levantamento da literatura. De uma maneira geral, o esforço será o de evitar, na medida do possível, o caminho inverso, isto é, a leitura dos dados empíricos a partir de um conjunto de teorias, com a pretensão de validar um conhecimento já constituído. Em outra palavras, trata-se de não somente pensar os eventos do ponto de vista do saber, mas pensar também os discursos científicos a partir de um conjunto de práticas. Isto posto, duas estratégias serão empregadas nessa articulação. Em primeiro lugar, a perspectiva a ser adotada será mínima e suficientemente genealógica, no sentido de apresentar não apenas a delimitação epistemológica, isto é, o recorte dos objetos, mas também a sua contextualização histórica, a partir da revisão crítica de sua construção. Depois, os estudos de caso serão usados na discussão sobre os mesmos, indicando os segmentos analisados que ilustram, aprofundam ou contrariam os argumentos teóricos levantados. A primeira parte, sobre autismo, música e palavra cantada, possui um caráter de definição geral de conceitos, localizando o recorte na literatura que fornecerá os eixos para a discussão posterior, mais focada nos aspectos específicos do dispositivo. Nessa segunda parte, os tópicos abordados são: narrativa, ritmo, corpo, imitação e identidade.

\subsection{Autismo}

Em uma primeira análise da literatura, o autismo se apresenta como um objeto de estudo de diversas disciplinas, que buscam não apenas defini-lo e explicá-lo, como também o empregam na elaboração e justificação de um conjunto de dispositivos e ações. Nesse sentido, ele existe não apenas como um quadro clínico, mas também como uma série de conhecimentos, instituições e práticas a ele orientadas. Com o objetivo de iniciar a discussão, partimos de uma breve revisão de alguns discursos a respeito do autismo, tendo em vista que noções centrais a este estudo - como as de desenvolvimento e psicopatologia infantil - possuem definições historicamente localizadas, cujas versões atuais adquirem a tonalidade de suas predecessoras e as- 
sumem sua relevância na medida em que são empregadas na constituição de modos de pensar a respeito desses sujeitos (HACKING, 2009). Em seguida, identificamos um conjunto de trabalhos que encontram na relação com a alteridade um modo de caracterização do autismo. Esse recorte permitirá uma reflexão a respeito da natureza das interações sociais associadas ao autismo, e guiará as discussões posteriores a respeito dos efeitos terapêuticos da música e das canções.

Segundo Lampreia (2004), o conceito de autismo é impreciso. Em sua descrição comportamental, ele abrange tanto crianças que falam quanto outras que não falam, crianças com pouco ou nenhum tipo de contato social e outras com um tipo excêntrico ou esquisito de relacionamento, crianças com deficiência mental e outras com um nível cognitivo adequado para sua idade. Com relação a seus aspectos etiológicos, a falta de consenso é ainda maior, a ponto de, para Leboyer (2007), existirem tantas definições de autismo quanto as diversas teorias que pretendem explicá-lo. São também poucos os acordos quanto aos prognósticos possíveis, fazendo do autismo um caso raro entre entre os quadros clínicos, a maior parte dos quais segue uma trajetória conhecida e predizível.

De acordo com Bosa e Callias (2000), apesar da variedade de disciplinas e estudos voltados ao autismo, a integração dos conhecimentos dessas distintas áreas é impossível pois os resultados não cobrem toda a extensão de diferenças individuais do espectro, e estão geralmente focados nas deficiências, sobretudo sociais, associadas ao quadro, mas não nas suas competências. O resultado é que o campo do autismo se constitui no interior do discurso científico como algo controvertido (WINNICOTT, 1966), que conduz facilmente a confusões e malentendidos quando empregado na identificação de indivíduos ou grupos. Em consequência, os estudos epidemiológicos também apresentam variações significativas, indo de 15 a cada 150.000 habitantes (ASSOCIAÇÃO AMERICANA DE PSIQUIATRIA, 2002) a aproximadamente 11 por 1.000, isto é, uma criança a cada 88 (BAIO, 2012). Trata-se, sem dúvida de um quadro pouco frequente, o que leva LaVietes (SHAPIRO et al., 1972) a questionar se o autismo infantil recebe uma atenção desproporcionada enquanto uma doença rara.

São poucas as descrições de casos de autismo na história, ao contrário de outros distúrbios mentais como a mania e a depressão, que são relatadas em textos da Antiguidade e no Antigo Testamento (SCLIAR, 2003). Ao longo dos séculos XVIII e XIX, crianças com autismo teriam sido diagnosticadas com idiotia, termo cuja única diferença com a loucura, de acordo com Foucault (2012), seria sua associação com um aparecimento precoce, abrangendo assim 
toda a psicopatologia infantil e de adolescentes. Esses indivíduos representavam um desafio à nascente disciplina psiquiátrica, que abdicou de seus métodos morais em favor de uma postura clínico-pedagógica, introduzida por Itard (1801) após sua experiência com o menino de Aveyron. Encontrado em um bosque por caçadores, Victor não falava ou entedia o que lhe era dito, fazia suas necessidades onde bem queria, não reconhecia sua imagem no espelho e recusava qualquer comida cozida, um quadro que hoje possivelmente seria considerado como de autis mo (FRITH, 1991). Contrariando o pensamento comum, o médico francês afirmava que o menino não havia sido abandonado por causa da ausência de fala ou dos comportamentos incomuns, mas que estes sim eram decorrentes do fato de que havia sido deixado à própria sorte, passando a infância separado de outros seres humanos.

O caso Dick, de Melanie Klein (1930/1996), é considerado um dos primeiros atendimentos de uma criança com autismo. Levado pela mãe, o menino de quatro anos parecia agir como se tivesse 15 meses. Apresentava uma fala reduzida, com pouco vocabulário e repetia palavras sem significado. Indiferente à mãe, não demonstrava ansiedade ou angústia frente à separação. Corria de um lado para o outro do consultório, e seus movimentos eram confusos e desastrados. Klein definiu o caso como uma inibição do desenvolvimento do ego, decorrente de uma ausência de vínculo com a mãe, mas ela possivelmente o teria diagnosticado com autismo se a categoria estivesse disponível na época.

Deve-se a Bleuler (1911/1950) o primeiro uso do termo autismo. Segundo Roudinesco e Plon (1998), buscando evitar a referência à sexualidade da palavra autoerotismo, empregada primeiramente por Havelock Ellis, e depois extensamente usada por Freud, ele teria recorrido a uma contração que aglutinasse os dois termos, resultando por fim no neologismo. A outra alternativa seria ipsismo, derivada da palavra em latim para si mesmo, o que indica que Bleuler queria denotar uma atitude de isolamento social e de fechamento à realidade externa. $\mathrm{O}$ autismo ingressava na história das ideias como um sintoma típico da esquizofrenia em pacientes adultos, junto com os distúrbios das associações, da afetividade e da ambivalência.

Antes de ser incorporado ao vocabulário da psiquiatria infantil, o termo foi também empregado em seu sentido genérico por Piaget (1923) em um trabalho apresentado em 1922 na Conferência Internacional de Psicanálise de Berlim, onde ele defendeu a ideia de que os estágios pré-verbais de pensamento de crianças normais poderiam ser descritos como autistas. A justificativa é que, durante essa fase, elas não seguiriam regras lógica nem usariam conceitos, havendo uma predominância de imagens visuais em suas mentes. É apenas com a publicação 
do artigo de Kanner (1943), descrevendo 11 crianças que ele havia acompanhado, que o termo autismo ganha uma definição na psicopatologia infantil contemporânea. Os sintomas relatados abrangiam distúrbios de comunicação que variavam da sua ausência à literalidade, ou seja, a inflexibilidade do sentido das palavras, que não eram usadas fora da conotação, e a tendência à regularidade extrema, com uma preferência pela repetição e preservação da igualdade de objetos e situações. $\mathrm{O}$ aspecto determinante do autismo, no entanto, era o isolamento social e a dificuldade de se relacionar com outras pessoas, condição que Kanner chamou de solidão autística extrema. Ele postulou que isso se relacionava a uma falta de consciência dos sentimentos dos outros, e mesmo uma dificuldade em reconhecê-los como entidades separadas.

No ano seguinte, Asperger (1944/1992) apresentou um estudo com 400 indivíduos que apresentavam uma psicopatia autística. Ao contrário dos pacientes de Kanner, essas crianças aparentemente falavam de uma maneira normal, mas eram cansativas e não-dialógicas. $\mathrm{O}$ uso da linguagem indicava uma outra faceta da dificuldade em relacionar-se com o outro, já que elas não possibilitavam a entrada de ninguém na conversa sobre algo que lhes interessava, e simplesmente abandonavam a interação quando isso ocorria. Essa diferença qualitativa resultou em uma suposta variação diagnóstica, conhecida a partir de então como autismo de alto funcionamento, ou síndrome de Asperger.

Na opinião de Winnicott (1996), ao inventar o autismo, Kanner não descobriu nada novo, mas definitivamente criou um cenário para o surgimento e desenvolvimento de uma doença. Logo, é como um transtorno mental que ele será apresentado à comunidade psiquiátrica, na terceira edição do Manual Diagnóstico e Estatístico de Transtornos Mentais (DSM) (ASSOCIAÇÃO AMERICANA DE PSIQUIATRIA, 1987), definido tanto por seu início muito precoce quanto por uma tendência evolutiva crônica. Considera-se que o autismo envolve alterações quantitativas e qualitativas da experiência subjetiva, dos processos cognitivos, da comunicação e do comportamento. Essas disfunções afetam o indivíduo de uma maneira integral, de modo que o autismo não corresponde a um atraso ou interrupção do processo típico de desenvolvimento, mas sim a um transtorno global do mesmo (pervasive developmental disease), cujos efeitos se estendem por toda a vida e afetam as distintas áreas desse processo, isto é, o desenvolvimento psicomotor, afetivo, cognitivo, linguístico, social, etc.

Segundo Lampreia (2004), a descrição apresentada pela quarta edição do DSM refletia a heterogeneidade dos quadros clínicos associados ao autismo, que podiam chegar a 96 a partir da combinação dos dois critérios de interação social, um critério de comunicação e um de pa- 
drões restritos e repetitivos indicados pelo manual. Essa situação foi revista na edição mais recente do manual (ASSOCIAÇÃO AMERICANA DE PSIQUIATRIA, 2013), na qual a doença é caracterizada por um espectro de condições e graus diferentes ao redor da mesma tríade de sintomas (interações sociais, uso da linguagem verbal e atividades restritas e repetitivas), uma ideia proposta originalmente por Wing (1981). Poderíamos, em lugar de autismo, falar de autismos (ROCHA, 1997).

Entre os caminhos para uma definição mais específica do autismo por parte da psiquiatria estaria a sua localização orgânica por meio de um marcador biológico, genético, neuroelétrico ou neuroquímico. Apesar dos esforços, essas tentativas até agora não obtiveram resultados conclusivos. Sabe-se que algumas regiões do cérebro estão desenvolvidas, mas não são funcionais (HILL, 2004). No entanto, a lista de anormalidades encontradas é tão difundida em loci do tronco cerebral, córtex límbico, neocórtex e cerebelo quanto o próprio sistema motor emocional, incluindo sistemas responsáveis pelos processos de consciência e aprendizagem (PANKSEPP, 1998), percepção de expressões comunicativas e reconhecimento dos estados mentais dos outros (TREVARTHEN, 2000). Mas apesar das evidências de uma diferença mensurável na atividade neural de autistas e não-autistas, as imagens do cérebro são incapazes de estabelecer a relação entre a atividade deste órgão e os sintomas específicos, isto é, qual é a causa e qual é o efeito.

Porém, é no campo da genética que atualmente ocorre a maior disputa pelas esperanças de uma etiologia ou cura para o autismo. Parte desse interesse decorre de estimativas estatísticas, como a de que gêmeos monozigóticos apresentariam uma taxa de concordância maior que dizigóticos no desenvolvimento da doença (RITVO et al., 1985). Contudo, apesar da suposta hereditariedade das anormalidades, possíveis correlações entre mutações genéticas e disfunções neurais tendem a ser ainda pouco conclusivas ou passíveis de generalização para os diferentes sintomas. Por outro lado, pesquisas têm mostrado que os genes que codificam as moléculas sinápticas - responsáveis pela comunicação entre neurônios - podem ter sua expressão alterada por fatores ambientais - como nutrição, medicamentos e estresse - sem alterações na sequência de DNA (MIYAKE et al., 2012). Em outras palavras, a patologia autística poderia ser não somente o resultado de uma falha congênita, mas também o efeito do ambiente sobre a carga hereditária. Essa hipótese epigenética reforça a ideia de que, apesar da possibilidade ou não de uma causa orgânica, as funções do desenvolvimento psíquico são extremamente sensíveis à qualidade dos cuidados e interações sociais que ocorrem em suas primeiras etapas, e que per- 
turbações dos mesmos podem ter efeitos globais e duradouros para o restante do ciclo vital.

Em contraposição à tortuosa evolução do conceito de autismo nas ciências biológicas, ele acabou recebendo diversas críticas vindas de outros grupos científicos e sociais. Apesar de Cohen e Volkmar (1997) terem encontrado crianças com autismo em diversas culturas, existem comunidades na qual ele não é nem reconhecido ou codificado como um transtorno mental (OCHS et al., 2004). Sendo uma construção social a partir de uma condição psicobiológica, ele depende de categorias de normalidade, desvio, competência e incompetência, que são cultural e historicamente variáveis, e cujos valores e implicações dependem de práticas sociais localmente enraizadas. Assim, no contestado mundo do autismo, existem também aqueles que afirmam que não se trata de um transtorno, mas sim de uma diferença.

Nos últimos anos, movimentos sociais em torno do autismo ganharam força e destaque na opinião pública. Paralelamente, com o avanço das tecnologias de comunicação, grupos essencialmente formados por pais e familiares se organizaram em uma comunidade internacional sobre o tema. Parte deles, orientada pela ideia de neurodiversidade, isto é, que as diferentes condições neurológicas correspondem a variações naturais na espécie, recusa a concepção de doença, apesar de não se opor à categorização de pessoas como autistas, no sentido de que elas possuem aspectos singulares que as caracterizam (HEADLAM, 2006). Muitos desses grupos defendem que o autismo seja considerado uma deficiência ou diferença benigna, como a surdez. Um dos exemplos usados na luta contra a patologização do autismo é o caso da homossexualidade, que já foi considerada um transtorno mental, sendo excluída do DSM nos anos 70, e que hoje é admitida como um modo de vida relativamente aceito pela sociedade.

O extremo dessa atitude seria a afirmação de que o autismo não existe - posição adotada mesmo por teóricos do porte de Winnicott (1996) -, e que, em verdade, corresponderia aos extremos menos comuns de um fenômeno extremamente complexo que é o desenvolvimento humano. E igual às demais deficiências, em que acomodações especiais são necessárias para a comunicação e aprendizagem, ainda que uma cura não seja necessária ou desejável, esse movimento demanda o acesso a direitos como escolas especiais, aposentadorias antecipadas e o incentivo a pesquisas sobre o quadro, apenas enquanto visem melhorar a sua qualidade de vida.

Evidentemente, esse movimento reage também à estigmatização do sujeito autista, almejando um entorno social mais compreensível e favorável, o que motiva até mesmo o estabelecimento de um Dia Mundial de Conscientização do Autismo. Tal questionamento, no entanto, parece ser válido sobretudo para alguns casos, em que o prejuízo às funções sociais e de 
linguagem não é tão grave a ponto de a criança gozar de uma relativa autonomia. É o que fica exemplificado no caso de Mathias, cuja mãe recusa um possível diagnóstico. Ele de fato apresenta um desenvolvimento desigual, com uma habilidade excepcional em algumas áreas, já que escreve e se comunica em português e alemão, além da facilidade com a música e temas científicos, mas não em outras, como a linguagem e a interação social. Trata-se de um caso que suscita, junto com a discussão levantada pelo movimento da diferença, a questão de se seria possí vel separar o desenvolvimento do autismo do desenvolvimento da criança em si. Haveria uma parte não-autista da sua personalidade, como afirmam Alvarez e Reid (1999) e Urwin (2002, 2011)? Seria possível uma busca pela sua autêntica voz? (RHODE, 1999)?

Essas são questões fundamentais para compreender a criança com autismo para além da determinação dos discursos disciplinares que pretendem engendrar noções de autocontrole, normalização e subjetivação, das quais o sujeito autista termina sendo um produto objetificado (VAKIRTZI, 2010). Ao contrário dos tipos naturais - como formas geométricas, espécies químicas e biológicas - cujos objetos são indiferentes à classificação que recebem, o diagnóstico de autismo seria um tipo interativo (HACKING, 2009), que não apenas descreve a sua realidade como também desempenha um papel fundamental na sua constituição, que tanto nomeia o indivíduo quanto molda seu comportamento, restringindo suas ações, desejos e potências. Em um certo sentido, o desenvolvimento do autismo parece se entrelaçar com o da própria criança, gerando confusão em pais, terapeutas e educadores, distantes de diferenciar a evolução da doença e a história desses indivíduos.

É imprudente e desnecessário considerar que o autismo consiste pura e simplesmente em uma invenção, algo que não precisa ser levado a sério ou mesmo que não existe. Penso ser provável que essa atitude resulte da situação atual dos tratamentos disponíveis para essa condição, ainda incapazes de oferecer um prognóstico de cura, no sentido de uma remissão completa da doença e a retomada das funções do desenvolvimento em um nível considerado típico. Mais interessante parece ser ser entender de que forma ele é moldado na intersecção entre as trajetórias singulares e os discursos a seu respeito. Como essas pessoas são pensadas e intervenções são planejadas para elas? Que lugares lhes são oferecidos na sociedade? Quais instituições serão indicadas? Enfim, o modo como toda uma estrutura social é manejada à sua volta, produzindo ações e enunciados que incidem sobre suas vidas e das pessoas que as acompanham.

Isto tudo certamente não é um detalhe menor do problema do autismo e de nossa compreensão a seu respeito. Muitas vezes, é possível reconhecer nos discursos certa ideia que ori- 
enta um ponto de vista muito específico. Como repara Pinheiro (1997), as metáforas popularmente empregadas para significar o autismo, como "tomadas desligadas", "conchas", "fortalezas vazias”, “carapaças”, “ovo”, “buraco negro”, circunscrevem também todo um imaginário teórico e clínico. Trata-se de definições negativas, que apontam a falta e o deficit, a ausência de desejo, de fantasia e de relação com o mundo e com a vida, representando as pessoas com autismo por aquilo que elas não têm ou não são.

\begin{abstract}
O sintoma distingue-se do deficit, como o positivo do negativo. Direcionar o tratamento para a construção do sintoma é destacar o que o sujeito faz para organizar-se, por mais simples que seja sua atividade, ritualística ou não, e por mais inusitada que seja sua montagem. Enquanto a concepção deficitária está sempre a apontar o que o sujeito não faz, mas deveria fazer, o critério do sintoma valoriza o que ele faz e, sobretudo, cava um espaço para que ele venha a fazer algo. Não se trata, por conseguinte, de incitar a criança a produzir isso ou aquilo, mas facultar-lhe a via de uma criação não definida a priori. Assim, um se torna ajudante de cozinha, outro um administrador de sua fábrica fictícia, ou gerente de um Banco, etc. (FREIRE; BASTOS, 2004).
\end{abstract}

Podemos dizer que os sujeitos que participaram desta pesquisa, durante momentos mais ou menos longos, mais ou menos frequentes, apresentavam comportamentos que não diferiam de todo do de qualquer indivíduo da sua idade, com suas fortalezas e debilidades singulares. Assim como William podia conduzir uma improvisação e desculpar-se chorando por empurrar uma colega, Mathias podia rir conosco e Camila correr atrás de Pablo. Elas revelavam aquilo que, antes de serem autistas ou não, antes de serem normais ou anormais, de fato são: crianças. Assim como Winnicott (1996), o que se poderia dizer, para além de qualquer consideração nosográfica ou diagnóstica, "é que algumas dessas capacidades podem ser monótonas, repetidas ou compulsivas e, em alguns casos, desprovidas de fantasias" (p. 83).

Tendo em vista a complexidade apontada pela revisão da literatura, um recorte a respeito das considerações sobre o autismo é necessário. A partir dos estudos de caso e da natureza interativa das práticas empregadas na oficina de música, por sua vez, deduz-se que os procedimentos do dispositivo incidem sobretudo na relação das crianças com os outros. Chama a atenção o fato de em diversos momentos elas terem demonstraram um vínculo interativo que sem a música seria distinto ou impossível. A interação entre Camila e Mathias na improvisação e recriação da canção de abertura da oficina (Fig. 22) é um exemplo disso. Mesmo as diferenças com relação aos aspectos comunicativos e comportamentais parecem estar associadas a essa nova qualidade da experiência compartilhada no interior do grupo. Nesse sentido, o autismo será considerado aqui sobretudo em seus aspectos sociais e de relação com a alteridade.

Nessa mesma linha, para Wing e Gould (1979), o espectro do autismo corresponde a um conjunto de síndromes cujo núcleo é um deficit social. Da mesma forma, Trevarthen et al. 
(1998) o consideram um distúrbio do mecanismo inato para se relacionar com o outro. As funções da linguagem - e os processos de pensamento nela baseados - estariam afetadas nas pessoas com autismo porque as funções intersubjetivas estão prejudicadas desde o princípio da vida. $\mathrm{O}$ estudo de vídeos caseiros com bebês que seriam diagnosticados como autistas, por Muratori e Maestro (2007a), e de um par de gêmeas das quais uma irmã seria futuramente diagnosticada como tal, por Trevarthen e Daniel (2005), confirmam que a perturbação no desenvolvimento da simpatia interpessoal é um efeito da ausência ou baixa frequência de comportamentos intersubjetivos. As diferenças nas funções comportamentais, emocionais ou cerebrais seriam, em sua opinião, resultante de deficiências no compartilhamento de atenção, intenção e afeto em um momento em que o encontro com o outro é fundamental.

Sem a troca de respostas expressivas e de orientação, a criança não participa plenamente das transações comunicativas e emocionais com os outros, o que compromete gravemente seu desenvolvimento orgânico e psíquico. Tal prejuízo das relações sociais na primeira infância dá origem aos sintomas associados, dado que reduz os movimentos de orientação mental que ocorrem em resposta aos estímulos do outro, o que afeta o desenvolvimento do pensamento e o empobrecimento da vida imaginativa (HOBSON, 2002). É importante frisar que esse ponto de vista implica a adoção de uma perspectiva contemporânea a respeito do desenvolvimento infantil (BRASIL, 2013), que o considera um processo resultante da interação entre fatores genéticos e ambientais, esses últimos sendo de natureza tanto psicossocial quanto ecológica. Implica também que a constituição do aparelho psíquico se inicia com a interação entre o bebê e seus cuidadores, em um processo cujos momentos decisivos se encontram já nos primeiros anos de vida.

O termo desenvolvimento, portanto, será compreendido aqui como produto da incidência de processos maturativos, tanto de ordem neurológica quanto genética, conjuntamente a processos de constituição do sujeito psíquico (KUPFER et al., 2010). Sujeito, por sua vez, será tratado como uma instância psíquica inconsciente, construída a partir de um campo social preexistente e de fatores acidentais como

a história de um povo, de uma família, do desejo dos pais mas também a partir dos
encontros, intercorrências e acasos que incidem na trajetória singular da criança. Do
campo da cultura e da linguagem virão as chaves de significação em torno das quais a
criança deverá construir para ela própria um lugar único. Desse processo, surgirá o
sujeito psíquico, aqui concebido como um elemento organizador do desenvolvimento
da criança em todas as suas vertentes física, psicomotora, cognitiva e psíquica (p. 48 ).

Conforme essas crianças crescem, os problemas encontrados nessas primeiras interações 
diádicas se estendem e afetam a maneira como elas interagem com o restante do grupo social e a sua aprendizagem das convenções culturais. Para um grupo de pesquisadores, essas dificuldades se relacionam a uma menor habilidade das pessoas com autismo em elaborar uma teoria da mente, isto é, a dedução das disposições internas de outra pessoa a partir do conhecimento prévio sobre suas experiências pessoais e personalidade, ou a partir do seu comportamento corporal, expressões faciais, qualidade de voz e ações (BARON-COHEN; LESLIE, FRITH, 1985). Indivíduos com autismo apresentam um baixo desempenho em experimentos em que se pede a eles que atribuam intenções, crenças e estados psicológicos a outras pessoas, uma condição que esses teóricos denominam cegueira mental (mind-blindness). Talvez isso explique porque os possíveis engajamentos sociais de Mathias passassem, antes, por uma etapa de surpresa e espanto diante de nossas ações (p. 84). Da mesma forma, os comportamentos hostis de William, bem como a cena do chocalho que atinge Sofia (p. 36-37), indicariam uma dificuldade de entender o significado para o outro de uma agressão sofrida ou um pedido de desculpas.

A validade desses experimentos, contudo, parece depender menos dos aspectos contingentes da interação social que da significação cultural dada aos comportamentos e trajetórias de vida. Mendoza (2012), por exemplo, em um estudo com o objetivo de validar a versão infantil do teste de leitura dos olhos - no qual devem identificar as emoções expressadas por imagens da região ocular -, não encontrou diferenças estatisticamente significativas entre o desempenho de um grupo controle de 434 crianças dos estados de São Paulo e Santa Catarina, e o de uma amostra de 20 crianças diagnosticadas com transtornos do espectro do autismo.

Para Ochs et al. (2004), uma das principais dificuldades enfrentadas por sujeitos com autismo no reconhecimento das intenções e estados psicológicos se refere ao descentramento sociocultural (socio-cultural decentering), isto é, a adoção do ponto de vista do outro por meio da "atenção dos membros às expectativas comportamentais associadas com situações cultural e socialmente organizadas" (p. 156). Analisando 381 horas de áudio e vídeo de 16 crianças entre 8 e 12 anos, diagnosticadas com autismo e Asperger, os pesquisadores encontraram diversos momentos em que elas faziam tomadas de perspectiva (perspective-taking) em situações de interação cotidiana, com membros da família em casa, indo e voltando da escola, e com os pares e professores. Os três domínios em que isso ocorria eram a participação em trocas de turnos e sequências de conversação, a formulação de cenários situacionais e a interpretação de significados socioculturais de formas e comportamentos indexicais. 
Apesar da tendência a perseverar em seus tópicos de interesse e de manter conversações entremeadas por silêncios, essas análises indicaram que, frequentemente, sujeitos com autismo participam de conversações com trocas de turnos em lugares de transição adequados, até mesmo engajando-se em discussões sem pausas ou sobreposições entre as falas. Isso sugere que as pausas não se relacionam a uma dificuldade cognitiva, mas sim à vulnerabilidade dessas crianças aos desafios da função pragmática da linguagem.

Da mesma forma, apesar de demonstrarem ter um sentido limitado do que era esperado delas e dos outros em uma gama de situações sociais, elas também eram capazes de organizar e coordenar a sua interação com os outros por meio de representações compartilhadas, mesmo que essa capacidade estivesse mais ligada a articular cenários socioculturais do que de fato participar deles. Em um exemplo extraído da amostra, um garoto de 11 anos com autismo projeta sua vida quando tiver 16 anos, junto de sua irmã menor. Ele se imagina dirigindo um carro, indo a festas com seus amigos, e até mesmo formula estratégias para lidar com a mistura de álcool e direção, demonstrando um conhecimento de trajetórias convencionais de vida e valores associados a uma outra idade. Essa competência em formular cenários situacionais pode, inclusive, levar a uma especificação de detalhes que as pessoas comuns não estão acostumadas, o que possivelmente se associa a um desejo por estruturações rotinizadas e predizíveis da sua experiência.

Por fim, o estudo mostrou que o domínio social que representava um maior desafio para as crianças autistas era a indexicalidade e a interpretação de significados culturais. Essa dificuldade está comumente ligada a um campo problemático maior, que inclui o uso de metáforas, mas também à habilidade de representar e reconhecer situações sociais a partir de um conhecimento de associações convencionais entre entidades de contextos sociais. Por exemplo, é possível associar o canto do galo com as primeiras horas da manhã, sem a necessidade de ter a experiência de ouvir o animal ou mesmo de viver em uma região rural onde eles se encontram. Mas, para uma criança que participou do estudo, é necessário um esforço adicional para compreender porque um personagem de desenho animado abria os braços, espreguiçando-se e fazendo caretas, após o som do galo cantar. É preciso uma explicação de sua mãe para que ele entenda que, ao fazer esse gesto, o personagem está comunicando que não quer se levantar, e que o canto do galo possui um significado compartilhado socioculturalmente.

Outro desafio apresentado pelas formas indexicais a indivíduos com autismo, além da designação de mais de um significado ou um significado não-literal a um significante, é a rapi- 
dez que é necessária à identificação desses sentidos em contextos de mudança de tema. Além disso, a interpretação de significados contextualizados requer que os significantes sejam vinculados não só às disposições psicológicas e atos sociais dos outros, mas a toda uma rede de atividades, identidades e instituições que estão sendo postas em jogo a qualquer momento.

Existe, portanto, uma diferença entre a habilidade de interagir e comunicar-se com o outro, falar-lhe e contar-lhe coisas, e estar com o outro, deixar-se afetar por sua presença, seus sentimentos e pensamentos, compartilhando com ele o pertencimento a um grupo social que dá sentido às palavras, ações e demais formas expressivas. Seria possível que um autista "aprendesse" habilidades interpessoais? Uma criança assim, nesse caso, poderia atribuir estados mentais a outros, estudando as correlações entre movimentos corporais, gestos e expressões faciais, reconhecendo-os em lugar de propriamente senti-los? E, nesse caso, poderia aumentar sua pontuação no teste de reconhecimento de expressões faciais e melhorar seu desempenho na teoria da mente? Ou agiria como uma máquina identificadora de emoções? Essas dúvidas são tributárias da redução do social ao intersubjetivo, em detrimento de sua dimensão cultural. É preciso, em outras palavras, pensar um sujeito não apenas em relação ao outro, mas também aos processos de significação compartilhada da realidade, à trama discursiva do Outro da cultura. Essa diferença será fundamental nas discussões posteriores, entre o outro como os indivíduos com os quais é possível estabelecer uma relação intersubjetiva, e o Outro, matriz dos símbolos de todos esses outros, que incide sobre o sujeito de uma maneira externa.

O conceito de Outro como distinto do outro (LACAN, 1987) é útil para distinguir, no campo da alteridade, a instância virtual de determinação simbólica da realidade, e os outros, os indivíduos singulares que produzem atos e enunciados particulares, sendo apreendidos imaginariamente pelo eu. Nessa perspectiva, o universo simbólico, ao mesmo tempo em que rege a percepção e a interação humana, está engastado nos processos de práticas coletivas que determina, o que o força a acompanhar a sua dinâmica evolutiva (ZIZEK, 2010). A evolução da palavra altera, portanto, o seu uso e valor, tanto que Lacan (2008) define o Outro como o "tesouro da linguagem" (p. 50) ou "tesouro dos significantes" (p. 56), no sentido de lugar onde se enraízam os valores socialmente compartilhados, depositário da economia dos jogos de linguagem que unem as palavras aos objetos, tal como definido por Wittgenstein (1953).

Segundo Zenoni (2002), é somente nesse campo da ordem simbólica e da cultura que o problema do autismo pode ser verdadeiramente entendido, pois sua sintomatologia indicaria uma captura absoluta na dimensão do Outro. Não corresponderia, desse modo, a um não aces - 
so ao simbólico, mas a uma inserção no simbólico que representasse um aprisionamento absoluto, sem limite (ZENONI, 1991). Um excesso de Outro, no qual são impossíveis

\begin{abstract}
a polissemia, a variabilidade, a incerteza. O outro terá significados fixos, sempre sígnicos. As variações serão vistas como um problema, e a elas a criança reagirá evitando-as. Isso mostra que localiza os outros, registra sua presença, mas se trata de uma presença que não é regida pelo significante, e sim pelo signo (KUPFER; INAFUKU; FARIA, 2008, p. 159).
\end{abstract}

Consequentemente, a alteridade se apresentaria para a criança de uma maneira intrusiva e persecutória, e os sintomas representariam o conjunto de defesas que protegem dessa invasão. Seus enunciados, ações e objetos se abrigariam da determinação comum da linguagem, perdendo o caráter significante e assumindo outras funções psíquicas. E ela rejeitaria sistematicamente a voz e o olhar, como se assim pudesse evitar também a presença ameaçadora do Outro.

Com esse arcabouço sobre o problema do autismo, que, apesar de sua indefinição conceitual, pudemos localizar na intersecção de processos psicológicos e fenômenos sociais e culturais, que determinam não só a doença em si, mas também os discursos e a maneira como a entendemos. Por consequência, a partir daqui, dois eixos deverão orientar a revisão crítica da literatura e a leitura dos eventos ocorridos na oficina, a saber, sua delimitação nos processos de desenvolvimento infantil e no campo sociocultural e intersubjetivo da interação com a alteridade. Seguimos para a segunda parte da nossa discussão, sobre o estatuto da palavra cantada. Pode ela auxiliar-nos na compreensão dessa síndrome? O que podemos entender sobre os efeitos terapêuticos da música e da canção quando consideramos um discurso que se dirige à criança com autismo nos limites do campo da linguagem, entre som e palavra?

\title{
4.2. Palavra cantada
}

Um dos aspectos específicos das sessões da oficina música foi o uso de canções. Apesar de outras formas musicais como a improvisação e os jogos musicais terem sido igualmente empregadas, a palavra cantada foi seu elemento característico na maior parte do tempo. Por esse motivo, a presente seção está focada nos discursos a respeito de sua natureza e as implicações que pode ter em um contexto clínico. Na literatura, a canção é um objeto de estudo localizável em distintas áreas das ciências humanas e biológicas, com seus respectivos pontos de vista. Partindo do pressuposto de que se trata de um fenômeno que se encontra na intersecção entre 
música e fala, o recorte da discussão sobre a canção será a relação entre a palavra cantada e a palavra falada. Essa aparente dicotomia será analisada em suas dimensões pragmáticas, linguísticas, neurológicas e poéticas, o que orientará uma reflexão sobre sua natureza. Em seguida, investigaremos as evidências de que os primeiros eventos comunicativos já comportam uma elaborada capacidade expressiva da voz, que se prolonga após a aquisição da linguagem e que sustenta a musicalidade da fala. Mais do que uma habilidade, essa peculiaridade da comunicação humana está diretamente envolvida nos primórdios da constituição da subjetividade e da relação com a alteridade, o que conduz a voz a uma posição de extrema relevância clínica. Nessa linha, algumas implicações dessa noção para a discussão dos estudos de caso são levantadas e uma reflexão é feita sobre os eventos da oficina em que uma qualidade incomum da voz dos participantes foi observada. Por fim, o uso terapêutico das canções em diversas sociedades é analisado, buscando entender as estratégias que garantem a eficácia simbólica das canções de cura nessas culturas.

A partir de uma abordagem musicológica, supomos o canto como algo que se adiciona à fala, sendo as notas da melodia uma informação adicional ao texto, que altera sua entonação, intensidade e ritmo, tanto ressaltando sentidos ocultos quanto fazendo com que significados explícitos passem desapercebidos. Não importa se esse processo se dá por uma analogia entre o contorno melódico e uma emoção que o compositor busca despertar, ou se é simplesmente o resultado de uma interpretação do ouvinte. $\mathrm{O}$ certo é que, tal como sugere Zuckerkandl (1976), a canção agrega um elemento significante ao código da linguagem, atualizando uma nova dimensão da palavra e de seu sentido. A ideia de dimensão pode ser entendida aqui literalmente, como em geometria: com a nota, a palavra ganha profundidade, volume e espessura, como se recebesse dela uma "outra camada de realidade" (p. 44).

Se analisados por separado, contudo, tanto o canto quanto a fala consistem em um conjunto de sons vocais produzidos com o controle do tempo. Se essa semelhança já seria suficiente para dificultar a construção de duas categorias de classificação absolutamente separadas, ela justifica noções ainda mais complexas como, por exemplo, a hipótese de Rousseau (1781/2008) de que a linguagem se originou da palavra cantada. Para esse autor, a primeira língua seria caracterizada por sons vogais, unidos por hiatos e com escassas articulações consonantais, fazendo com que o sentido resultasse de variações na duração e altura das sílabas. Na lógica rousseauniana, isso decorre da ideia de que a linguagem não teria se originado da necessidade de transmitir imagens e conceitos ligados às necessidades, mas sim para para comunicar senti- 
mentos e afetos, "para emocionar um jovem coração, para repelir um agressor injusto", não foi "a fome ou a sede, mas o amor, o ódio, a piedade, a cólera, que lhes arrancaram as primeiras vozes” (p. 266). Rousseau chamou essas modulações de acentos (accent), e apesar de terem desaparecido com a evolução da linguagem, supostamente eram encontrados no grego antigo, aproximando essa língua da melodia cantada, dotada de ritmo e entonação. Inversamente ao ponto de vista de Zuckerkandl, não é a música que oferece algo de positivo à linguagem, mas sim esta última que subtrai da primeira sua paixão e melodia.

Os resultados das pesquisas arqueológicas de Falk (2000) corroboram essa noção, sugerindo que mesmo os primeiros hominídeos, como o Australopithecus, haviam desenvolvido modos musicais de comunicar suas emoções e afetos, possivelmente em coro e com o auxílio de percussões (MERKER, 2000). Apesar de essas serem hipóteses especulativas, Dissanayake (2001), ressalta que estão em sintonia com o conhecimento atual sobre a evolução dos primatas, tanto com relação a aspectos fisiológicos e anatômicos - como as características do trato vocal e do aparelho auditivo -, quanto aspectos neurológicos - como a capacidade manter o tempo em sincronia com um marcador externo.

Se nos atentarmos às características estruturais de canto e fala, similaridades e diferenças são encontradas com relação a seus aspectos acústicos. Ambos podem ser analisados, por exemplo, em função da altura, duração, timbre, intensidade, acentos e padrões de inflexão. Segundo Marsola e Baê (2000), tanto a voz cantada quanto a falada apresentam variações de altura, porém a tessitura da primeira é de 3 a 5 semitons, enquanto a da segunda pode ultrapassar as 3 oitavas, o que representa uma amplitude de frequências até sete vezes maior. Com relação às intensidades, Behlau e Rehder (1997) registram que a voz falada mantém-se relativamente constante durante o discurso, situando-se ao redor de $64 \mathrm{~dB}$, com variações usuais em torno de $10 \mathrm{~dB}$. A intensidade da voz cantada, por sua vez, quase nunca é constante, e pode apresentar variações rápidas de um pianissimo a um fortissimo, de $45 \mathrm{~dB}$ a $110 \mathrm{~dB}$, uma intensidade até seis vezes maior que a da fala.

Da mesma forma, ambas são construídas sobre sistemas sintáticos que organizam os padrões sonoros (KIVY, 2002). Do ponto de vista pragmático, o sentido das palavras e dos sons é moldado e transmitido pelo contexto sociocultural, por meio de processos de aprendizagem e práticas comunicativas. A diferença entre ambas reside em seu aspecto semântico, pois enquanto a palavra encontra seu uso na referência denotativa e conotativa a objetos, eventos, conceitos e estados internos, os sons musicais não possuem, a princípio, um sentido referencial ex- 
tramusical.

Do ponto de vista neurológico, as funções da fala estão localizadas em uma rede neural restrita e lateralizada, enquanto a base neuroanatômica das funções musicais é ampla e dependente de diversas subfunções perceptivas, cognitivas, motoras e emocionais, com localizações assimétricas e espalhadas pelo cérebro (THAUT, 2005). Algumas áreas de processamento da linguagem e da música tendem a coincidir, por exemplo, com partes dos lóbulos frontal e temporal-parietal, mas as demais estruturas ativadas pela música são funcionalmente autônomas e separadas da fala e da escrita. O compositor russo Vissarion Shebalin, por exemplo, poucos meses após sofrer um derrame que aumentou as dificuldades de fala provocadas anos antes por um episódio similar, pôde completar sua quinta sinfonia sem problemas. Já Maurice Ravel, que começou a apresentar sintomas de afasia após golpear a cabeça em um acidente em 1932, tornou-se progressivamente incapaz de escrever música, sem perder a capacidade de escutá-la e entendê-la. Essa sobreposição neurológica entre as funções da fala e da música torna o uso de canções uma ferramenta promissora no tratamento de distúrbios relacionados à linguagem. Em um estudo com ressonância magnética funcional realizado por Lai et al. (2012), crianças com autismo apresentaram respostas funcionais reduzidas à estimulação pela fala nos giros inferiores frontais esquerdos e nos córtices auditivos no lóbulo temporal esquerdo. Quando a estimulação era com canções, por sua vez, houve um aumento na ativação no giro frontal inferior esquerdo e na conectividade funcional frontal-posterior, relacionada à fala.

Outro campo do conhecimento no qual a noção de continuidade entre canto e fala pode ser encontrada são os estudos de poética da canção. Segundo Tatit (1995), cantar "é uma ges tualidade oral, ao mesmo tempo contínua, articulada, tensa e natural, que exige um permanente equilíbrio entre os elementos melódicos linguísticos, os parâmetros musicais e a entoação coloquial" (p. 9). É a entonação da voz que une a melodia às palavras, estendendo a fala ao canto ou, como ressalta o autor, produzindo a fala no canto. $\mathrm{O}$ resultado, para ser convincente, precisa neutralizar a oposição entre as unidades linguísticas discretas e a continuidade melódica da fala, e nesse sentido a palavra cantada elimina "a fronteira entre o falar e o cantar" (p. 11). De fato, segundo Reinach (2011), na Antiguidade grega, não havia poesia que não fosse escrita para ser lida em voz alta e tampouco canto que não incluísse palavras. Já na Idade Média, Santo Agostinho (1993) postulou que o canto e a reza deveriam ser considerados como casoslimites da linguagem, pois tanto em uma canção sem conteúdo e um discurso sem sons, o que acompanha o sujeito é apenas uma coisa: a voz. Extrapolando as características morfológicas, a 
distinção entre essas duas categorias no âmbito religioso pode ser tão sutil a ponto de, em algumas práticas islâmicas, o canto religioso não ser considerado música, embora soe musicalmente a um ouvido ocidental (SEEGER, 2007). Tendo em vista que, naquela cultura, a música é associada à dança e a relações impróprias entre as pessoas, o canto é visto apenas como um discurso, um sermão.

Desse conjunto de perspectivas, podemos considerar o canto como sendo de difícil compreensão quando se parte da dicotomia entre fala e música. Na medida em que sintetiza campos com características compartilhadas, porém com aspectos contraditórios, a palavra cantada lança uma nova luz às distinções entre canção e fala, linguagem verbal e não-verbal. Talvez a questão seja que elas não se distinguem em seus aspectos estruturais, mas em sua convenção cultural. Em outras palavras, não resultam de uma distinção objetiva, mas de intenção. A alternativa adotada aqui para compreender a palavra cantada será a de suspender a discussão sobre seu uso mais corrente, deslocando-a ao estudo da gênese da linguagem no desenvolvimento infantil precoce, quando as fronteiras entre sons e palavras ainda não estão completamente delimitadas, e a comunicação depende da musicalidade para ocorrer.

Segundo Boysson-Bardies (1991), a visão tradicional de que o bebê está acusticamente isolado no interior do útero, em um silêncio acolhedor, foi negada com as pesquisas atuais sobre o desenvolvimento. Apesar de o sistema perceptivo do feto provavelmente não diferir entre as modalidades de estímulo, o aparelho auditivo já funciona a partir da $25^{\mathrm{a}}$ semana de gestação, sendo que seu nível de audição na 32a semana já é próximo ao de um adulto. Os sons do corpo e da voz da mãe, e outros originados no exterior, são os elementos que compõem esse primeiro universo sonoro intrauterino. A respiração, o sangue circulando e os movimentos gastrointestinais formam uma textura sonora ritmada que, apesar da sua intensidade, ocupa uma faixa de frequências relativamente mais baixas do campo perceptivo do feto. É por isso que as vozes da mãe e dos outros podem ser percebidas praticamente sem interferência, como linhas melódicas que emergem de um acompanhamento grave e contínuo. A voz da mãe, por ser transmitida tanto pela via externa quanto por ressonâncias através do corpo, atinge-o com uma intensidade praticamente idêntica ao que escutaríamos fora do útero. Sua qualidade espectral também é preservada, com uma leve atenuação das frequências mais agudas. Isso significa que, durante todo o último terço da gravidez, o bebê já conhece um mundo sonoro que é o mesmo que ele vai encontrar depois que nascer. Somos levados a pensar que os primeiros sonhos seriam sonoros, como propõe Benenzon (1988). 
Em experimentos com uma chupeta eletrônica capaz de monitorar o comportamento de sucção, DeCasper e Spence (1986) descobriram que bebês de apenas 12 horas preferem escutar a voz da mãe que a de outra mulher. Em geral, ela empregará nos contatos com seu filho uma qualidade vocal exclusiva, diferente da que usa nas conversações com os adultos. Suas sílabas serão alongadas e ocuparão uma frequência alta do espectro das alturas. Além do mais, ela se caracterizará por modulações de altura que lhe darão um contorno melódico específico, pró ximo ao canto e que transmite uma qualidade emocional equivalente. Esse tipo de fala orientada a bebês é denominado por Fernald (1985) de manhês (motherese).

Também conhecido como parentês, de modo a abranger os pais, ou discurso dirigido ao bebê (infant-directed speech), esse modo particular de falar não é usado praticamente em nenhuma outra ocasião, a não ser com animais de estimação ou com robôs, não importa a sua cultura (DUPOUX; MEHLER, 1990). Para Papoušek e Papoušek (1982), o parentês é a principal fonte de estimulação musical no início da vida, definido por uma estrutura simples de convites ao diálogo e alturas agudas, com a predominância de intervalos de terça menor, contornos crescentes para chamar a atenção e decrescentes para acalmar, jogos imitativos e padrões repetitivos.

Nesse sentido, o registro vocal empregado pelo cuidador na interação com o bebê demonstrou que as qualidades sonoras das vocalizações têm um papel crucial em seu desenvolvimento, já que estes apresentavam mais respostas contingentes quando aqueles se dirigiam a eles usando o parentês (MURATORI; MAESTRO, 2007b). Problemas no desenvolvimento infantil, pelo contrário, estão relacionados a uma baixa frequência desses comportamentos comunicativos, e a voz dos cuidadores nesses casos é grave e monótona, semelhante àquela da conversação com outros adultos (LAZNIK et al., 2005).

A importância da musicalidade nas primeiras interações sociais não pode ser, portanto, subestimada. Como observou Trevarthen (1974), uma criança de sete semanas já apresenta uma forma de pré-fala, na medida em que os movimentos dos lábios e da língua lembram aqueles de articulação da linguagem do adulto, juntamente com os movimentos da cabeça, dos olhos e das mãos. Ao mesmo tempo, uma forma de percepção pré-linguística do recém-nascido está presente desde os primeiros três ou quatro dias, quando já são capazes de diferenciar determinados contrastes fonéticos, como a prosódia e a altura (BOYSSON-BARDIES, 1991).

Essa capacidade precoce de percepção e produção de sons é o que torna possível as primeiras interações vocais, denominadas protoconvesações (BATESON, 1979). Tais expressões 
comunicativas são facilmente organizadas em padrões de tempo, forma e intensidade, que se encadeiam no tempo e permitem a coordenação dos seus estados internos com os de seu cuidador. São padrões que orientarão as ações dos dois parceiros, permitindo que uma sincronização rítmica recíproca e um acoplamento das formas expressivas sejam estabelecidos por suas afinidades miméticas e deem sentido à interação (TREVARTHEN, 1999). A constituição dessas sequências espaciais e temporais possui uma importância fundamental na maturação do psiquismo, e os jogos e brincadeiras têm uma relevância na montagem dessas sequências (WINNICOTT, 1975), e permitem que a experiência seja incorporada à mente através de envelopes psíquicos (HAAG, 2006) ou envelopes sonoros (ANZIEU, 1995), que dão forma à representação dos contatos com a realidade externa. $\mathrm{O}$ som pode exercer um papel fundamental nesse processo, produzindo um envoltório intermediário entre o corpo e o exterior, servindo nos primeiros meses como espécie de pele para a incipiente formação do eu.

O bebê pode reconhecer um estado mental no outro com base nessas mudanças micromomentâneas de intensidade, tempo e forma do comportamento do parceiro, percebidas como semelhantes às suas próprias expressões. À dinâmica intensiva desses contornos de ativação, Stern $(1985,1999,2000)$ deu o nome de afetos de vitalidade, ou seja, contornos de intensidade que não remetem ao conteúdo da experiência, mas ao modo como ela se desenvolve no tempo. Nesse sentido, eles se definem melhor em termos cinéticos e dinâmicos, como "emergente", “afastando-se”, “indo-se”, “explosivo”, “atraído”, “esforçado”, “acelerando”, “desacelerando”, “chegando no clímax", "estourando", "puxando", etc. Os afetos de vitalidade informam o bebê de que ele está diante de um outro ser vivo e provavelmente são o primeiro modo de conhecimento do mundo, indicando as qualidades emocionais ligadas ao modo como os comportamentos são realizados. Em um vídeo analisado por Stern (1985), por exemplo, uma menina de nove meses, animada com relação a um brinquedo, estende a mão em sua direção e, enquanto o agarra, solta um “ahh”. Simultaneamente com o "ahh”, a mãe faz uma dança, balançando o seu corpo com a mesma ativação do som do bebê. A forma e a intensidade dos movimentos da dança e os sons da vocalização variam ao longo do tempo de uma maneira semelhante, indicando que estas são correspondências transmodais, capazes de acoplar os distintos padrões de movimento e som em formas expressivas comuns a todas as modalidades de expressão.

A partir da análise de vídeos das interações entre mães e bebês, Stern et al. (1985) identificaram momentos em que ambos faziam ajustes na interação para compartilhar e comunicar seus estados emocionais, o que ele denominou afinações afetivas (affective attunement). Uma 
mãe pode, por exemplo, contribuir para a protoconversação diminuindo seu ritmo de fala, oferecendo uma quantidade maior de repetições e correspondendo à intonação dos sons produzidos pela criança. Mesmo indicando uma predisposição a sustentar a troca comunicativa, as afinações afetivas são algo a ser construído na interação com o bebê. Em vez da noção mais ro mantizada que mães e filhos se comunicam de maneira sincronizada, Cohn e Tronick (1989) demonstraram que eles estabelecem um processo flexível de correspondências, falta de correspondências, e retorno à correspondência, em sucessivas interrupções e reparações. Isso indica que um dos aspectos fundamentais na interação é a estrutura de troca de turnos, mas também que há uma dinâmica interativa instável que é frequentemente recriada e incorporada à memória, o que amplia o repertório comunicativo da dupla e torna os padrões de forma, tempo e intensidade cada vez mais complexos. Eles atuam como músicos tocando junto a um novo companheiro com quem, apesar de terem se conhecido recentemente, podem improvisar livremente ou sobre standards mutuamente conhecidos, que lhes organizam uma estrutura de entradas e finais, melodias e acompanhamentos, solos e duetos.

Todas essas pesquisas indicam que a sensibilidade social das crianças pequenas se expressa em sua facilidade de lidar com aspectos formais de comportamentos interativos e comunicacionais que são os mesmos que constituem a música. Como afirma Trevarthen (2002), "as nuances musicais fundamentais que um músico pode achar interessantes - relacionadas ao ritmo, à afinação, à harmonia, melodia ou timbre - podem também interessar a um bebê” (p. 89-90). É provável que esse início precoce, associado a uma série de experiências de observação e repetição, seja o responsável pela capacidade musical tão desenvolvida, mesmo em crianças muito pequenas, como vimos na seção anterior.

Ao longo do desenvolvimento, a musicalidade comunicativa é portanto um fator determinante para o início e apoio das relações intersubjetivas, muito antes que estas sejam intermediadas pela linguagem. Deve-se a ela a existência de uma verdadeira pré-linguagem de intenções e emoções (PAPOUŠEK, 1996). Nesse sentido, como ressalta Lampreia (2004), a oposição ou identidade entre o desenvolvimento linguístico e social é um falso problema, ou uma questão mal colocada, na medida em que a relação com o outro se desenrola em um contínuo que vai da sensibilidade social e se prolonga até a aquisição da comunicação verbal. A musicalidade comunicativa se estende pelo resto da vida do sujeito, subjazendo aos usos da linguagem, sob a forma da interação não-verbal ou dos componentes paralinguísticos da comunicação, mas também derivando nas capacidades humanas inatas para a produção e apreciação 
de todos os tipos de música (BLACKING, 1995).

Essa habilidade inata é atualizada pelo sujeito ao longo de sua história, e possivelmente se conserva mesmo em crianças com problemas graves no desenvolvimento, como no caso do autismo (ALVIN; WARWICK, 1992; NORDORFF; ROBBINS, 2004; TREVARTHEN, MALLOCH, 2000; TREVARTHEN, 2002; LIMA, 2012). Ela pode ser utilizada para estabelecer uma interação até mesmo com sujeitos na faixa mais grave do espectro do autismo, como fica exemplificado na seguinte vinheta clínica de López (2010):

\footnotetext{
Após várias tentativas fracassadas de aproximação, foi criada a improvisação de uma melodia no violão usando seu nome como letra, sendo a primeira vez ao longo do processo que Rafael dirigia o olhar. Com a repetição da música, criada com seu nome, Rafael aos poucos foi se aproximando. Ficava atento e permitia ser tocado pela música. Ao longo dos atendimentos, Rafael, cantarolando a melodia, solicitava que as sessões iniciassem e terminassem com a sua música (p. 13).
}

Outro aspecto que chama a atenção no relato é o uso do nome, parte da identidade do sujeito. Se atentarmos, assim, à ideia de identidade sonora, seria lógico tensionar uma passagem daquilo que é inato e próprio à espécie para aquilo que é singular ao sujeito e sua trajetória pessoal. Os aspectos sonoros da realidade à disposição do bebê, como vimos, surgem em um momento relativamente anterior à concepção, e logo em seguida se manifestam as habilidades em lidar com os aspectos musicais do mundo humano. Possivelmente, a construção de um sentido de self e os atos de comunicação compartilham dessa capacidade de dar sentido às formas sonoras e gestuais, de modo que a identidade é desde cedo musical e coreográfica. Mas essa equivalência será válida para todas as etapas do desenvolvimento subjetivo? A seguir, aprofundaremos a discussão a respeito do papel da voz nas etapas iniciais da constituição do sujeito psíquico, com o objetivo de dar conta dessa questão.

Apesar das evidências a favor da percepção transmodal do bebê e das indicações de uma variedade de elementos possíveis para a comunicação coordenada entre ele e sua mãe, desde as variações na voz, no olhar, nos gestos corporais, com seus detalhes rítmicos e de intensidade, quando nos concentramos em suas preferências, Fernald e Kuhl (1987) encontraram dados mais restritos. Para testar experimentalmente os determinantes acústicos que mais lhes agradavam, as pesquisadoras apresentavam sons sintetizados com a manipulação da frequência fundamental, da amplitude e duração próprias a discursos com as caraterísticas do manhês e da conversação entre adultos. As falas eram apresentadas em caixas localizadas em um dos lados do bebê, sendo a preferência medida pelo comportamento de virar a cabeça em direção à fonte do som. As conclusões foram que a amplitude e o ritmo da fala não tem o mesmo impacto na 
seleção de audição que a frequência fundamental, indicando que o que está em jogo na preferência pelo manhês é a melodia da fala. Possivelmente, os picos prosódicos da sua voz são as primeiras formas de vitalidade que a criança experimenta ainda no útero, mas as autoras sugerem que esse aspecto está ligado também a um caráter emocional positivo, que transmite alegria e prazer. Desprovidos do conteúdo linguístico e dos reforços visuais e gestuais que acompanham a fala, portanto, os contornos melódicos da voz são aqueles que mais atraem a atenção dos bebês.

Tão logo nos concentramos no sentido da fala, perdemos a percepção consciente das qualidades particulares da voz, cuja materialidade se opõe à idealidade do significado - apesar de resultar da primeira, o significado não contribui para a sua existência. Nesse sentido, a voz corresponde também àquilo que não contribui para fazer sentido (MILLER, 1989). Para Dolar (2006), três aspectos da voz contribuem à sua recalcitrância ao significante: o sotaque, que leva a voz à vizinhança do cantar; a entonação, que altera o sentido dos enunciados, até mesmo transformando-os ironicamente em seu oposto; e o timbre, isto é, o modo particular de cada pessoa produzir sons, sua característica reconhecível e identificável. Uma outra justificativa para isso seria, como define Brown (2000), a possibilidade de contrapor sons vocais de diferentes fontes, o que revela, a um só tempo, o embricamento do sujeito com a alteridade. Ao contrário da fala, que exige uma alternância entre o falar e o escutar, e torna praticamente impossível que duas pessoas se entendam falando ao mesmo tempo, quando cantamos podemos vocalizar simultaneamente, coordenando nosso comportamento expressivo para produzir um sentido comum, mesmo com textos diferentes.

Além disso, a relação da prosódia da voz com o gosto e o prazer da escuta indica que existe na fala algo que é irredutível ao sentido, isto é, que não existe em função da sua inteligibilidade ou capacidade de transmitir um conteúdo. Há uma dimensão da voz que não caracteriza nenhum objeto no mundo senão o próprio sujeito e seu desejo. Como destaca Kauffman (1998), se atentarmos para as modulações da voz e o ritmo da elocução do discurso, observamos que ele raramente é homogêneo: "Ora grave, ora aguda - ora colorida, ora 'branca' -, ora regular, ora precipitada, a voz habita as palavras a ponto de indicar o que poderíamos chamar de variações tópicas no discurso" (p. 696).

De fato, um dos aspectos mais intrigantes do trabalho com crianças com autismo é a sua voz. Existe uma grande atenção na literatura a esse respeito, geralmente focada em sua ausência, ainda que uma parte desse foco também se dirija ao seu uso. Segundo Wing (1996), pesso- 
as com autismo possuem dificuldades com a entonação e o controle da voz. Isso implica em uma entonação peculiar, que pode ser monótona ou carregada de inflexões inadequadas, ou com um volume de fala alto ou baixo demais. A autora propõe que a voz pode ter também uma qualidade timbrística mecânica, semelhante à de um robô. Em uma análise acústica realizada por DePape et al. (2012), adultos com autismo empregaram uma extensão limitada de alturas para responder a perguntas sobre imagens projetadas na tela de um computador. Mesmo indivíduos com um grau menos severo de autismo tampouco usaram a prosódia para marcar a estrutura de informações dos enunciados, apesar de usar uma gama maior de frequências fundamentais. Já em um estudo com crianças com e sem autismo, Bonneh et al. (2011) encontraram nas primeiras uma extensão e variabilidade maiores que nas do segundo grupo.

Por vezes, é possível reconhecer nessas crianças uma "outra voz" ou uma "voz especial" que, de acordo com Wing (1996), pode ser uma cópia de algo que escutaram ou uma tentativa de provar sons diferentes. De fato, a experimentação com a voz é algo próprio das crianças. Para elas, é atrativo brincar com as vocalizações, imitar as vozes dos outros, os sons dos objetos, dos animais, etc. Aos 5 anos, apresentam uma variabilidade espectral e temporal na fala muito maior que adultos ou crianças mais velhas, seja entre uma criança e outra da mesma idade, seja a mesma em diferentes momentos e para diferentes palavras e sons (GEROSA et al., 2006). Essa variação nas características vocais é efeito tanto das mudanças anatômicas e fisiológicas no desenvolvimento orgânico quanto da crescente habilidade na produção e articulação de sons. Com o passar do tempo, espera-se que a voz torne-se cada vez mais uniforme, isto é, que a variação no mesmo sujeito dos parâmetros acústicos seja reduzida conforme aumenta a idade, sobretudo até os 11 ou 12 anos (LEE; POTAMIANOS; NARAYANAN, 1999). Durante o período dos 11 aos 15 anos, surge uma diferenciação na variabilidade da qualidade vocal entre meninos e meninas, pois as mudanças nas frequências dos formantes dos primeiros apresentam uma linearidade conforme a idade, o que não é tão evidente para as meninas.

Chama a atenção o fato de alguns participantes terem apresentado, nas sessões da oficina de música, uma produção vocal com uma qualidade distinta e reconhecível em momentos específicos. Essas modulações não são apenas explicadas por uma entonação com o objetivo de determinar o sentido dos enunciados, devendo ser também lidas na chave do timbre da voz, tal como enfatizado por Dolar (2006). A análise acústica de uma vocalização de William revelou uma variação mínima de frequência e uma faixa de harmônicos graves, que conferiam à voz um aspecto gutural e rouco (Fig. 13). Já a análise da vocalização de Mathias apresentou con- 
tornos prosódicos acentuados e poucas pausas entre as palavras (Fig. 28). A partir da literatura, temos que a variabilidade e extensão das frequências fundamentais usadas pelos indivíduos com autismo sugere, de fato, que sua voz seria mais melódica, ou possuiria contornos prosódicos mais exagerados. Sharda et al. (2010) deduzem, pela semelhança dessas características com as do manhês, que essas crianças apresentariam uma trajetória de fala atrasada. Para Bonneh et al. (2011), por outro lado, essa diferença se deve a deficits nos mecanismos que controlam o pitch da voz, em sua produção ou recepção, possivelmente associados a um processamento auditivo anormal mais geral. As ocorrências de uma voz diferente ou especial na oficina de música, no entanto, parecem estar associadas a um contexto afetivo intenso, no qual pareciam tomadas por uma excitação emocional. Isso indica que existe um fator ligado à experiência subjetiva que determina a qualidade das vocalizações produzidas por estas crianças, irredutível a uma estruturação puramente orgânica, seja do aparelho fonador ou do sistema auditivo. É possível que problemas de constituição da voz estejam implicados nesses fenômenos, e que a dimensão desejante do sujeito tenha que ser levada em conta na sua explicação.

Como vimos, mesmo antes do nascimento, os picos prosódicos emitidos pela mãe, ao chegar aos ouvidos da criança, estabelecem zonas erógenas ao mesmo tempo em que a voz se constitui como um dos primeiros objetos da pulsão (LAZNIK, 1999), elemento fundador do audível. Essa anterioridade da voz com relação aos demais objetos pulsionais, como o olhar, o seio da mãe ou outras partes do corpo, coloca-a no centro da primeira forma de funcionamento psíquico (CATÃO, 2009), se considerarmos as pulsões como o aspecto originário da subjetividade (FREUD, 1905/1976).

Essa dimensão desejante do sujeito corresponde ao marco de uma primeira alteridade que se inscreve no inconsciente do bebê, já que os aspectos prosódicos da voz da mãe fazem com que o desejo do outro seja registrado no aparelho psíquico. Mais do isso, a voz indica que o primeiro ato subjetivo seria a invocação do Outro, ação que Lacan (1998) definiu como "a mais próxima da experiência do inconsciente” (p. 102). De acordo com Didier-Weill (1997a, 1997b), isso ocorre porque ela é o meio pelo qual se funda a relação mais primordial do sujeito com o Outro, aquilo que Freud (1905/1976) definiu como o recalcamento originário (Urverdrängung). É a voz quem "funda, ao mesmo tempo, o sujeito e o Outro, sem que jamais pertença nem ao sujeito nem ao Outro" (VASSE, 1977, p. 220). É por isso que o olhar e a voz não só são incluídos por Lacan (2005) entre os objetos da pulsão, como também recebem um estatuto de ainda maior importância, na medida em que se referem à relação fundamental com o 
fora (o outro) e o dentro (o self) (ZIZEK, 1997).

Assim como a boca orienta a dinâmica da pulsão oral, para Lacan (2005), a voz enquanto objeto põe em funcionamento o que ele chama de pulsão invocante, definida na medida em que é usada para convocar o Outro (VIVÈS, 2005). É a melodia da voz da mãe que atrai o bebê, que faz ele dirigir-se aonde ela está, da mesma forma que seu grito é respondido pela presença da primeira, sucessivamente. E esses mesmos ciclos de repetição organizam uma dinâmica que transmite as demandas de um ao outro e se inscreve no psiquismo da criança. Antes mesmo que o estádio do espelho encontre suas condições de operação no desenvolvimento da visão, a voz fornece os elementos fundamentais de identificação ao sujeito, sendo para ele o primeiro eco (PORGE, 2014), uma precoce confirmação de que existe um eu e um outro. Em realidade, como aponta Vasse (1997), a voz está presente no psiquismo antes mesmo da constituição do eu, como um conjunto psíquico pré-individual, um esboço de unidade e identidade. Mais tarde, tomada como envelope sonoro, a voz "entra na estruturação posterior do eu, da mesma forma, diríamos, que a imagem especular” (KAUFFMAN, 1998, p. 696). Nesse sentido, o movimento da voz compõe um circuito à pulsão invocante, no qual a energia psíquica pode circular e criar uma primeira forma de laço social. Como as ondas do oceano, ela forma o litoral entre o sujeito e o Outro (CATÃO, 2009).

Nessa perspectiva, o sujeito se instala quando o circuito da pulsão pode se fechar, já que é somente com a dimensão da alteridade que a função pulsional pode operar (LACAN, 1985). Assim, a qualidade do laço social é determinante na passagem dos objetos da ordem da necessidade para a ordem do desejo: aquilo que faz com que comida seja um alimento psíquico e não apenas um nutriente, que permite a instalação do olhar enquanto função psíquica para além da visão e, analogamente, ocorrendo o mesmo com a voz. Para alguns pesquisadores, é justamente uma falha na instauração do circuito pulsional que define que um sujeito se torne autista, com um simultâneo comprometimento do laço social (LAZNIK, 1998; LAZNIK et al., 2005; CATÃO, 2009). Laznik et al. (2005), analisando vídeos com bebês que se tornaram autistas e seus pais, concluíram que as interações sonoras entre eles não apresentam as características usuais do manhês, e que as crianças, por sua vez, eram mais atraídas pelos objetos que pelas pessoas que as chamavam. Isso indica um prejuízo à elaboração da função psíquica da voz e, consequentemente, de toda a constituição subjetiva e da relação com a alteridade. No entanto, isso não parece ser suficiente para eliminar a sensibilidade ao manhês, conforme pode-se observar nas gravações de uma criança de apenas seis meses, o pequeno Marco (LAZ- 
NIK et al., 2005). Sem responder às iniciativas dos pais de estabelecer um contato, o bebê participa de uma inesperada troca de olhares e vocalizações com um tio, que passava por ali por acaso. A análise acústica revela que ele, ao contrário dos pais, apresentava em sua voz as qualidades prosódicas do manhês, o que explica sua capacidade de convocar o sobrinho para a interação.

Após a entrada na linguagem, a musicalidade da voz segue veiculando sua função psíquica invocante, em detrimento das funções linguísticas. Esse movimento corresponde ao que Lecourt (2011) chama de desmame musical, que conduz a musicalidade comunicativa ao psiquismo inconsciente. Inconsciente porque a voz se converte em uma espécie de silêncio da fala. Não um silêncio como falta ou ausência da fala, mas sim aquilo que dela não se percebe conscientemente. Silêncio análogo ao que aparece na obra de John Cage, na peça 4'33" - na qual o intérprete se mantém em silêncio e os sons são aqueles que se originam da plateia e do ambiente -, ou no experimento com a câmera anecoica - na qual o compositor pôde identificar um som grave e um agudo que eram emitidos involuntariamente pelo sistema sanguíneo e o sistema nervoso, respectivamente. Um silêncio paradoxal, equivalente ao ruído de fundo.

Essa característica da linguagem, que a aproxima da experiência do inconsciente porque permite deslocamentos e condensações entre significantes em função da sonoridade, foi enfatizada por Lacan (2000) por meio do neologismo lalíngua (lalangue). Curiosamente, o modo como esse autor formula o conceito já explica, de alguma forma, o seu sentido: buscando referir-se ao "Vocabulário de Psicanálise", o autor comete um ato falho e diz "Vocabulário de Filosofia”, de André Lalande, sobrenome cujo som se assemelha ao de Laplanche - autor do primeiro livro -, e é reaproveitado para nomear o conceito. Se tal substituição do nome em função da homofonia demonstra em ato a emergência das formações do inconsciente, sugere também que a musicalidade inconsciente opera uma deslocamento nas posições e relações definidas pela estrutura da linguagem, produzindo um não-sentido, ou outro sentido. Como enfatiza Azevedo (2014), a "lalíngua partilha dessas duas posições: algo nela incide no domínio da decifração e do sentido; outro, indecifrável, marca-se pela insistência da letra, pela aliteração e pela lalação". É possível remeter esse mecanismo aos processos de criação poética, mas sem deixar de lado a sua sistemática presença na vida cotidiana. De fato, é o está encapsulado na situação em que, após a minha pergunta de para onde havia ido o rato da canção "O rato ladrão", e da resposta de William de que havia ido para a ratoeira, Mathias responde espontaneamente, "E foi pro ratoeiro" (p. 69). Trata-se de um enunciado localizado em um limite: entre 
letra e música, fala e voz, palavra falada e palavra cantada. E, certamente, dividir os risos motivados por aquele equívoco representou também uma espécie de comemoração compartilhada.

Cantar, desse modo, leva a voz do sujeito de volta ao primeiro plano da fala, às custas do significado socialmente convencionado das palavras. Isso o torna, como nota Dolar (2006), uma forma supostamente precária de comunicação. Como um exemplo, ela cita os esforços realizados para regular o canto sacro e evitar a sua capacidade de borrar a palavra e tornar o texto incompreensível, reduzindo a fascinação exercida pela voz. É a voz que funda, assim, as formas expressivas musicais, sendo a música a arte do tempo capaz de regular o objeto voz (MILLER, 1989), oscilando entre o sentido e o mais além do sentido. Pois, alheia a qualquer possibilidade de unificação por meio da imagem, a voz permanece, ao longo do desenvolvimento, um verdadeiro suporte da diferença (VASSE, 1977), aquém e além da determinação linguística.

Existe, portanto, uma dimensão intrapsíquica dos efeitos terapêuticos da música, apoiada na função psíquica da voz. Ao contrário dos aspectos intersubjetivos e socioculturais, que serão aprofundados nas seções seguintes, sua operação não é observável, pois seus aspectos metapsicológicos se deduzem da fenomenologia dos efeitos mensuráveis. Contudo, apesar de corresponder a estados mentais internos, ela está igualmente ancorada na relação com a alteridade, já que está envolvida na ativação de um circuito pulsional que produz no corpo orgânico a primeira dinâmica interativa com o Outro. Se encontramos na voz um dos elementos fundamentais para a constituição da subjetividade, parece plausível a hipótese de que ela exerce um papel essencial na construção da identidade sonora.

Nesse sentido, como entender o modo pelo qual uma canção pode dar voz a conteúdos que nela encontram um modo de enunciação singular? Essa seria a intenção da canção pessoal do "Rato ladrão" que, apesar de ter sido orientada à experiência de Pablo no hospital, termina sendo usada para trazer à situação clínica seus conflitos familiares, elemento que naquele então parecia representar os limites da sua própria identidade. $\mathrm{O}$ uso terapêutico das canções pode, então, ser justificado no apoio que elas oferecem à expressão das ideias, memórias, sentimentos, desejos e fantasias mais prementes. Um outro, e célebre, exemplo de canção pessoal é "Strawberry Fields Forever" dos Beatles, cuja letra se refere à infância de John Lennon. Strawberry Fields era um orfanato da organização de caridade Exército de Salvação, em cujo jardim ele brincava com os amigos. Como Lennon relatou em uma entrevista ao jornalista Bob Spitz (2005), o verso "No one I think is in my tree" [Acho que não tem ninguém na minha árvore] se referia à sua própria solidão e timidez, em um gesto que o compositor chamou de "psicaná- 
lise em forma de música" [psycho-analysis set to music] (p. 641). Não chega a surpreender, portanto, que o próprio Lennon a tenha considerado como uma das poucas canções verdadeiras que havia escrito (SHEFF, 2000).

Assim como na sociedade ocidental, encontramos exemplos de canções de cura em outras culturas, as quais serão nosso foco de estudo até a conclusão desta seção. Esse deslocamento pode apresentar um diferencial para a compreensão do uso terapêutico das canções, considerando que "os processos de adoecimento e cura no nível fenomenológico não são diferentes em natureza em outras culturas que a nossa, mas que tradições de cura interrogam diferentes questões sobre a natureza do adoecimento e da cura, que orientam suas práticas terapêuticas” (LANGDON, 1995, p. 7). Questões estas que podem, mais que fornecer soluções a nossas próprias indagações, iluminar regiões ainda obscuras de nossas práticas.

Da mesma forma que na oficina de música, diversas tradições terapêuticas não-ocidentais envolvem a execução de canções em grupo, ou a recriação de uma canção dirigida a um indivíduo. No ritual de cura de uma menina do povo Piman, nativo da região central e meridional do Arizona, por exemplo, Bahr e Haefer (1978) descreveram a reunião organizada para cantar, durante aproximadamente quatro horas, sob a orientação de um cantor, junto da doente, que repousava em uma cama próxima ao grupo. Essas canções, consideradas por eles como de "vitalização", eram alternadas com descansos, aplicações de talismãs e conversas com a família. Igualmente, os Temiar da Malásia, no processo terapêutico descrito por Roseman (1991) também incluíam uma performance na qual um coro feminino repetia os versos de uma canção de cura apresentada pelo curandeiro, enquanto produzia um acompanhamento com bambus percutidos em um tronco. Já entre os Ayoreo do Gran Chaco, entre o Paraguai e a Bolívia, são comuns os sarode, cantos de cura repetitivos e simples que podem ser usados por qualquer um para curar dores de dente ou nas pernas, convulsões, exaustão, feridas causadas por onças, etc. (RENSHAW, 2003). Outro exemplo, recolhido por Pratt (2007) é o dos Wakuénai, do norte da Venezuela, que empregam duas canções em seu ritual de cura: uma que nomeia o que está fora de equilíbrio no indivíduo, na ordem social e no ambiente natural; e outra que restaura a harmonia dessas relações.

De acordo com Pratt (2007), as canções são uma das ferramentas mais importantes nos processos de cura tradicionais. São usadas para acessar o poder dos espíritos, entrar em transe, dar poder a remédios e também como um remédio em si. São cantadas para curar os doentes, mas também para encontrar uma presa na caçada, fazer plantas crescer, confundir inimigos e 
ajudar pessoas em todos os tipos de problema ou perigo, sendo geralmente específicas para cada um desses casos. Independentemente de seus objetivos, contudo, pode-se dizer que o poder das canções reside menos em seu texto que em seu contexto, isto é, em sua performance, já que a linguagem não apenas registra ou expressa o poder de um praticante, como também o cria (DUBOIS, 2009). Como reforça, as canções de cura "refletem uma confiança antiga e disseminada na eficácia das palavras não apenas para descrever, mas também para atrair e moldar destinos individuais" (p. 204).

Um exemplo do modo como as canções atuam em processos terapêuticos é a análise feita por Lévi-Strauss (1975) de uma canção de cura obstetrícia dos Cuna do Panamá. No relato etnográfico, um xamã é convocado para auxiliar uma parteira, cuja paciente em trabalho de parto experimenta uma grande dificuldade em dar a luz. O diagnóstico é que $M u u$, a entidade responsável pela formação do feto, apoderou-se da alma da futura mãe, de modo que o tratamento deve consistir na busca dessa alma perdida para que o bebê possa nascer. Para tanto, o processo terapêutico se baseia na narração, pelo xamã, da entrada na vagina da paciente dos nelegan, seres invocados para realizar um exame ginecológico e fornecer um mapa uterino, similar a uma ressonância magnética. A paisagem narrada comporta montanhas, monstros fantásticos e animais ferozes responsáveis pelas dores do parto, mas o objetivo é justamente descrever esse panorama à doente, nomeá-lo, apresentá-lo "de uma forma que possa ser apreendida pelo pensamento consciente ou inconsciente" (p. 225-226). São os nelegan que vencem todos os obstáculos para a descida do bebê, que ocorre quando a alma da parturiente é finalmente liberada. A canção pode então terminar, na medida em que agora todos os protagonistas (recém-nascido, xamã, parteira, doente, Muu, nelegan) reencontram seu lugar e ingressam numa ordem sem ameaças nem desequilíbrios.

Mas qual é a fonte do poder das palavras do xamã ou, como nomeia Lévi-Strauss, sua eficácia simbólica? Como podem as palavras incidir no funcionamento de um sistema orgânico, como o aparelho reprodutivo? O essencial nesse processo é o compartilhamento de um sistema simbólico que dá sentido à experiência, e cuja aceitação é reforçada pela narrativa mítica, independentemente de uma correspondência à realidade objetiva. $\mathrm{O}$ que a doente não aceita são as dores incoerentes e arbitrárias, de modo que a cura consiste aqui em "tornar pensável uma situação dada inicialmente em termos afetivos, e aceitáveis para o espírito as dores que o corpo se recusa a tolerar" (p. 228). Isso posiciona a cura xamanística a meio caminho entre a medicina orgânica e práticas terapêuticas psicológicas, como a psicanálise. Ambas propõem a 
condução à consciência de conflitos e resistências até então inconscientes, mesmo aquelas cuja origem é orgânica.

Em ambos os casos também, os conflitos e as resistências se dissolvem, não por causa do conhecimento real ou suposto, que o doente adquire deles progressivamente, mas porque este conhecimento torna possível uma experiência específica, no curso da qual os conflitos se realizam numa ordem e num plano que permitem seu livre desenvolvimento e conduzem ao seu desenlace (p. 229).

E apesar de não estar explícito na análise do antropólogo, o fato de esse processo ser operado por meio de uma canção não parece ser inócuo na produção dessa "experiência específica". A partir do que foi discutido anteriormente, possivelmente existe algo no ato de cantar que potencializa as palavras a exercer determinados efeitos sobre o psiquismo, e assim alcançar os efeitos terapêuticos esperados. Como vimos, essa operação não depende apenas do conteúdo significante do discurso, dado que se vincula a seu caráter prático, ao canto como ação e performance, voz e lalíngua, musicalidade comunicativa. Contudo, o que o desfecho do caso sugere é que a palavra cantada enfatiza um aspecto peculiar da linguagem: sua narratividade. Nesse sentido, ela atribuiria poder à palavra porque, tal como vimos anteriormente, acrescenta uma nova dimensão ao discurso, capaz de ordenar o real e conferir à experiência uma condição de inteligibilidade ao longo do tempo. Como conclui Lévi-Strauss,

O xamã fornece à sua doente uma [linguagem], na qual se podem exprimir imediatamente estados não-formulados, de outro modo informuláveis. E é a passagem a esta expressão verbal (que permite, ao mesmo tempo, viver sob uma forma ordenada e inteligível uma experiência real, mas, sem isso, anárquica e inefável) que provoca o desbloqueio do processo fisiológico, isto é, a reorganização, num sentido favorável, da sequência cujo desenvolvimento a doente sofreu (p. 228).

Apesar de a questão da narrativa merecer um aprofundamento mais detalhado a seguir, a discussão a respeito da natureza da palavra cantada oferece uma ampla perspectiva de análise dos eventos ocorridos na oficina. Trata-se de um debate relevante para esta investigação, à medida que os efeitos terapêuticos da música geralmente são creditados à sua capacidade de engendrar canais de comunicação não-verbal entre terapeuta e paciente (BENENZON, 1985; ALVIN; WARWICK, 1991; TREVARTHEN; MALLLOCH, 2000). Essa noção se apoia na ideia de que os contornos de vitalidade que subjazem à música e à dança são formalmente vazios de conteúdo, mas também intrínsecos a toda e qualquer experiência, o que permite a comunicação e a interação mesmo quando o uso da palavra não é possível.

No entanto, as similaridades estruturais entre canto e fala explicitadas por diversas disciplinas e áreas de pesquisa indicam que as considerações a respeito do verbal e do não-verbal como categorias separadas e dicotômicas podem ser repensadas quando observadas a partir da 
óptica sintética de uma raiz comum: a musicalidade comunicativa. De maneira invertida, podemos imaginá-las em uma relação de continuidade, tal como se experimenta ao cantar uma canção, interagir com um bebê ou cometer um ato falho. Todos esses eventos demonstram a riqueza que a musicalidade comunicativa imprime no uso cotidiano da linguagem. Nessa linha, a palavra não simbolizaria apenas a razão e a ordem, pelo menos tanto quanto o não-verbo não representaria o livre e o caótico. Pelo contrário, também as palavras se desorganizam e se misturam entre si, assim como a musicalidade e o gestual possuem uma lógica e uma estrutura significante. $\mathrm{O}$ discurso se compõe dessas duas dimensões em permanente interação, o que implica refletir sobre uma ética do sujeito entre o verbal e o não verbal. Mais importante que isso, impedir o estabelecimento entre elas de uma relação hierárquica ou causal.

Em segundo lugar, podemos entender como a palavra cantada possibilita, ademais, a emergência no discurso de um sujeito posicionado em relação à diferença, à mudança e à transformação. A voz, considerada em suas diversas dimensões, indica que os efeitos terapêuticos da música se relacionam a uma dinâmica intrapsíquica, ainda que vinculada à alteridade, como fica evidente nas sessões. Essa relação entre sujeito, outro e Outro ganhará contornos mais claros quando a abordarmos, na seção seguinte, sob uma nova perspectiva, propriamente musical.

\subsection{Música}

A seguinte seção apresenta uma discussão sobre o conceito de música, a partir da revisão narrativa sobre o tema e dos eventos ocorridos na oficina de música. Adotamos aqui a proposição de Brito (2007), de que pensar sobre a música é produzir ideias de música, buscando identificá-las nas perspectivas do pesquisador, dos participantes e da literatura. Não obstante, concordamos também com DeNora (2004), parafraseando uma citação de Lévi-Strauss (1964, p. 89): a música - assim como os animais, como escreveu o antropólogo - não é apenas boa para se escutar, é boa para se pensar. Nossa proposta é que, por ser caracteristicamente uma prática, pensar a música - assim como refletir sobre as dimensões extramusicais associadas aos modos e situações nos quais ela está presente na vida humana - é pensar com ela, pensar com a música.

Acompanhando nossos objetivos, a música é considerada aqui em sua aplicação clínica, 
associada a seus efeitos terapêuticos. Trata-se de uma ideia que provavelmente remonta a um tempo anterior aos papiros egípcios de 1.500 a.C. que são considerados os primeiros registros escritos sobre o assunto (LEINIG, 1977). Claro também está que o uso da música no tratamento de diversas doenças foi recomendado ao longo da Antiguidade grega, justificado por seus efeitos harmonizadores e catárticos. Da Idade Média - quando surgem as primeiras escolas de medicina - até hoje, a música ampliou sua aplicação terapêutica, abrangendo a cura ou reabilitação de enfermidades como dor crônica, ansiedade pós-operatória infantil, dor póscirúrgica e infarto agudo no miocárdio (TODRES, 2006).

Em realidade, pelo menos desde a década de 60 (SILVA JÚNIOR, 2008), o uso da música como recurso terapêutico vem recebendo crescente importância pela comunidade científica, interessada nos efeitos e qualidades que estão associados a seu uso como tal. Em um estudo de relatos de uso da música como recurso terapêutico, Blasco (2002) resumiu uma série de qualidades da música que poderiam justificar essa propriedade, entre as quais figuram algumas inerentes às artes em geral - poder de sugestão e devaneio, poder de projetar sentimentos e conflitos, realização imaginária de desejos inconscientes por meio do prazer estético -, além de outras próprias à música - função comunicativa da expressividade pessoal, caracterização como linguagem pré-verbal ou não-verbal e fenômeno social de interpelação e resposta, isto é, de individualização e socialização. Outras pesquisas reunidas pela autora apontam a ação da música sobre o metabolismo de plantas e animais, afetando a liberação de hormônios e neurotransmissores que podem aliviar a dor, apresentando outros efeitos fisiológicos - a regulação do ritmo cardíaco e respiratório, a pressão sanguínea, a resposta galvânica da pele e seu nível de condutância - e respostas musculares e motoras - como o reflexo das pupilas à luz, os movimentos peristálticos do estômago e a produção de sucos gástricos -, além do aumento da atividade muscular e da resistência à dor.

Em uma revisão criteriosa da literatura sobre musicoterapia e tratamento de autistas incluindo apenas ensaios clínicos que compararam a musicoterapia com uma terapia de placebo, nenhum tratamento ou uma atenção padronizada -, Gold, Wigram e Elefant (2008) concluíram que, apesar de os estudos apresentarem uma aplicação limitada para a prática clínica, os achados indicam que a musicoterapia pode ajudar as crianças com o transtorno de espectro autista a melhorar suas habilidades comunicativas. Técnicas fundamentais da musicoterapia, como a improvisação livre e estruturada, escutar músicas ou compor canções, podem ser empregadas no tratamento de dificuldades na comunicação, conduta e interação social do sujeito 
diagnosticado como autista. Elas podem promover o desenvolvimento de habilidades comunicativas e um aumento contínuo dos atos comunicativos e respostas (EDGERTON, 1994) e, se aplicadas a longo prazo, seus padrões de relação social podem mudar e se desenvolver (SCHUMACHER; CALVET-KRUPPA, 1999). Além dessas investigações, outras duas revisões (BALL, 2004; WHIPPLE, 2004) também indicam que o uso de técnicas da musicoterapia foi eficiente para pessoas com transtorno do espectro autista.

Ainda com relação ao recorte conceitual desta pesquisa, a música esteve desde o início atrelada à noção de musicalidade, isto é, a capacidade humana de conferir um sentido a formas e qualidades das expressões sonoras e corporais no tempo. Musicalidade, nesse sentido, não significa uma habilidade pessoal singular, como poderia ser um dom ou um talento, nem os aspectos particulares da música de uma cultura específica. Como notado por Blacking (1995), essas são variações interpessoais e interculturais que podem apresentar uma grande magnitude, enquanto que a noção de musicalidade se refere aos aspectos psicológicos da experiência musical, dos quais pode-se extrair princípios com certa constância. Ademais, na presente pesquisa, essa perspectiva se fundamentou principalmente nas habilidades comunicativas evidenciadas no desenvolvimento infantil precoce. De acordo com Nordorff e Robbins (2004), a ideia de musicalidade também justifica as práticas de musicoterapia, relacionando-se à "universalidade da sensibilidade musical - a herança da sensibilidade complexa ao ordenamento e relação do movimento tonal e rítmico; ela também aponta para a significância distintamente pessoal das respostas musicais de cada criança” (p. 1).

A vantagem que apresenta a noção de musicalidade sobre a de música é a de estender a experiência musical a atos que possivelmente não seriam considerados como tais, como é o caso da brincadeira do trem de William (p. 49-50). Mesmo incluindo elementos sonoros limitados - pouco mais que nossas vozes e imitações do som da locomotiva -, é possível identificar nela uma série de aspectos próprios ao campo da música, tais como a dinâmica crescente e decrescente da composição, a continuidade de um movimento, intercalado com pausas nas estações, a entrada e saída de passageiros, com seus efeitos no volume do objeto criado com nossos corpos, etc. São todos eles aspectos que podem ser encontrados nas atividades que consideraríamos como estritamente musicais, por exemplo, as canções de abertura e encerramento. É exatamente nesse sentido que as diversas atividades da oficina podem ser analisadas sob a perspectiva das suas qualidades expressivas no tempo, e o modo como estas são responsáveis pelo desenvolvimento de um sentido compartilhado. 
Mas, qual era a ideia de música para os participantes? Acompanhando as sessões de perto, vemos que eles se apropriam das definições oferecidas pelos adultos, e que a música na maior parte das vezes correspondia àquilo que havíamos proposto, ou seja, as canções. Era a partir do cancioneiro montado gradualmente por nós que as crianças faziam a sua seleção para responder à pergunta: “Que música vamos tocar agora?”. No entanto, podemos entender que outras ideias de música trazidas por elas também orientavam nossas atividades, como, por exemplo, a "Música da ilha do Medonho" (p. 50-51), "Música assustadora” (Fig. 12), e "Música do tubarão" (Fig. 18, 26), de William, e a "Música do relógio”, de Mathias (p. 87). Todas elas, em maior ou menor grau, eram o resultado de improvisações e jogos musicais, de modo que, se recriadas em outra sessão, adquiriam novos contornos e possibilidades, mesmo que mantivéssemos a estrutura original. Por serem formas relativamente abertas, eram música no sentido de um processo de criação. No entanto, a música apareceu também de formas ainda menos organizadas e mais espontâneas, sem ser nomeada, nas vocalizações cantadas de William, nos miados de Pablo e Sofia depois de recriarmos “O gato folgado” (p. 89-90), no chacoalhar da flauta de pã por Camila (p. 73), etc.

Enfim, se adotarmos uma ideia suficientemente ampla de música, tal como a que propõe Campbell (1988), percebemos que ela "acontece com as crianças” (p. 4, grifo da autora). Com efeito, em sua etnografia do comportamento musical infantil, ela o observou em distintos locais e contextos, muitas vezes de uma maneira inconsciente. Seja nos momentos explicitamente dedicados à música, como o estudo e a audição, ou nas demais atividades do seu dia a dia, ela flui de suas vozes e corpos mesmo sem que elas a percebam.

Uma parte dela pode estar escondida, inexplorada, e ainda assim girar dentro delas.
No entanto, muito dela está "visível" e certamente audível. Ela se mostra nas canções
que elas cantam e nos ritmos e inflexões de tom de suas brincadeiras - nos balanços e
escorregadores; nos carros de brinquedo, vagões, e bicicletas que elas montam; através
das histórias que elas encenam com os ursos de pelúcia, bonecas e motoristas imagi-
nários de seus minúsculos carros de corrida; e nos cantos de pular corda, rimas de ba-
ter palmas, jogos com bola e com varas, e nos jogos de anel e linha que elas jogam. As
crianças pensam em voz alta através da música. Elas socializam, desabafam emoções,
e se divertem através da música. Seus corpos se esticam, dobram, caminham, saltam e
pulam de formas rítmicas, enquanto suas vozes melódicas sobem e descem, ficam rá-
pidas, em seguida, lentas, barulhentas e, depois, suaves. Sua música pode ser "vista" e
ouvida em seus comportamentos lúdicos, entre os quais a execução das canções em
suas cabeças. É quase como se as crianças exalassem música (p. 13).

Para além dos limites da experiência musical infantil, o que as crianças nos lembram é que a música, como resume Small (1995) é ação, "é algo que as pessoas fazem”. E assim, recordando-nos do seu caráter eminentemente prático, a associação que elas tornam tão evidente entre música e movimento, gesto e ato, representa algo bastante distinto de uma ideia de músi- 
ca enquanto objeto. Seria por uma dupla operação do pensamento que música se transforma nas obras de arte que são o orgulho e glória do Ocidente: primeiro, elidindo-se suas qualidades performáticas, sendo objetificada e equiparada a uma coisa; em seguida, assumindo a suposição de que é nesses objetos que sua natureza e significado residem, de modo que os efeitos suscitados pela música seriam, em realidade, os efeitos de uma obra musical. Para esse autor, o correto seria que a palavra música fosse, mais que substantivo, um verbo, musicar (musicking): "a natureza fundamental - e, portanto, o significado da música - não reside nesses objetos, mas no ato de musicar. Encontra-se naquilo que as pessoas fazem. Objetos musicais só têm sentido na medida em que contribuem para a atividade humana que é musicar”.

Conforme cresce e seu universo social se expande para além do núcleo familiar, uma mudança ocorre no modo como as crianças percebem a música. Segundo Brito (2007), entre os três e os cinco anos, elas passam a reconhecer que a atividade musical é algo disseminado por toda a comunidade, e que seus efeitos corporais e afetivos são comumente compartilhados nos acontecimentos da vida social. Elas logo percebem que as qualidades da música servem para animar, sejam ocidentais ou Kayamurá, como aponta Menezes Bastos (1978).

Ao compor algo tão intrínseco ao ser infantil - de modo que podemos observá-la, para além da sua dimensão sonora, na conduta gestual e lúdica -, a experiência musical se manifesta no curso do desenvolvimento não apenas como expressão estética, mas também como jogo. Um “jogo de crianças”, como diz Delalande (2003), dado que nele encontramos todos os níveis da atividade lúdica definidos por Piaget (1951): o prazer sensual, o sentido e o valor simbólico, a organização de elementos em um todo. Jogo "de relações entre sons e silêncios, no tempoespaço", a música se faz no horizonte do brincar da infância, compartilhando com ele sua potência de transformação de si e da realidade, "modo de vida que vem e vai, que flui sem vencedores ou perdedores, que é jeito de perceber, de sentir, de viver” (BRITO, 2007, p. 43).

Algo que contribui para essa naturalidade da música é uma espécie de conhecimento musical intuitivo que as crianças demonstram no seu modo de produzir, escutar e pensar a música. Aparentemente, suas ideias de música são construídas desde muito cedo, como mostra uma interação narrada por Brito (2007) entre Felipe, de quatro anos, e sua mãe, quando esta é chamada para acompanhá-lo ao piano. Após a recusa da mãe, que diz "Eu não sei tocar. O papai é quem sabe porque ele estudou. E você também vai aprender quando começar a vir à escola de música", ele responde "Não precisa, não. Eu já sei tocar! Vem aqui que eu ensino você: é só apertar que o som sai!" (p. 97). O que importa é produzir o som e investigar relações - entre 
qualidades expressivas, entre gestos e sons - e não exatamente a definição de alturas e as regras de consonância e tonalidade. Essas características levam essa pesquisadora a aproximar as produções musicais infantis das proposições estéticas do músico e compositor Hans-Joachim Koellreuter (1987/1988), ao encontrar nelas um predomínio de três aspectos: o relativismo, dado que todos elementos apresentam uma relação com os demais; a imprecisão, já que em lugar de eventos sonoros com altura e duração definida encontramos tendências; e o paradoxo, pois conceitos aparentemente opostos podem apresentar uma relação de complementaridade.

De fato, se pensarmos que nenhuma instrução era dada com relação ao modo de tocar um instrumento ou cantar uma canção, as crianças que participavam da oficina encaravam a tarefa de um modo bastante espontâneo. Evidentemente, foi necessária a construção de um ambiente e de um vínculo entre todos no grupo para que essa naturalidade ocorresse. Ao mesmo tempo, o cuidado com os instrumentos era sempre lembrado, e sugestões e orientações eram feitas, como quando se sugeriu a Pablo uma maneira de golpear o tambor enquanto dizia as sílabas do nome do instrumento. No entanto, não havia uma preocupação de que os participantes produzissem um produto determinado ou que melhorassem uma habilidade musical específica, como poderia ser a intenção de uma prática de educação musical formal.

Mais do que transmissão, o movimento do conhecimento que podemos compreender nas sessões da oficina possuía uma qualidade de construção. Mesmo para aquelas canções que fizeram parte de nosso repertório desde o começo - "O pato pateta" sendo um exemplo -, as recriações eram o espaço para descobrir ou inventar algo novo, alguma letra, expressão ou gesto que pudesse ser acrescentado ao que havia sido trabalhado até então. Nesse sentido, a música era, além de jogo, brinquedo, objeto que se usa de novo a cada brincadeira, e que participa de uma série de novas experimentações (BRITO, 2007). Essa dimensão do brinquedo fica clara quando remetida à materialidade do instrumento, como exemplificado nesta anedota do compositor e saxofonista Ornette Coleman, ao ganhar seu primeiro instrumento aos 14 anos. Sem dinheiro para as aulas, o menino não deixou que isso o impedisse de tocar. Como disse Coleman: "Eu pensava que a música era apenas algo que os seres humanos faziam naturalmente, como comer. Eu pensei que [o saxofone] era um brinquedo e apenas toquei. Não sabia que você tinha que aprender alguma coisa para descobrir o que o brinquedo faz" (FORDHAM, 2015). No entanto, é possível pensar que essa qualidade lúdica se encontra também, para além do som e do objeto que o produz, na própria ação musical, “o fazer música é mais um dos brinquedos com os quais elas interagem (...), por esse ângulo, é tal e qual brincar de casinha, de su- 
per-heróis, etc." (BRITO, 2007, p. 98).

Como qualquer brincadeira, a música articula as ações do sujeito ao campo da cultura, que provê de significações os objetos e determina os usos e valores que estes podem assumir. Desde o início, nossa intenção foi a de estimular a escolha musical dos participantes, buscando aquelas canções que eles mais gostassem e os estilos que mais lhes interessassem. Contudo, nota-se um desequilíbrio quando analisamos o repertório da oficina sob as quatro categorias apresentadas anteriormente (tradicionais, contemporâneas, improvisadas e pessoais), mormente entre as duas primeiras, tendo em vista a presença no repertório infantil de jingles de propagandas, aberturas de desenhos animados e outros programas, além de canções não direcionadas ao público infantil. Chamou a atenção, por exemplo, durante a preparação da Festa Junina, o desconhecimento por parte dos participantes de algumas canções tradicionais - sendo que “Cai, cai balão”, proposta pelo pesquisador, não foi reconhecida nem ao menos pelos estagiários. Ao mesmo tempo, Sofia escolheu para a ocasião a canção "Na sola da bota", da dupla sertaneja Rionegro \& Solimões, que se tornou popular após fazer parte da trilha sonora da novela "América". É curioso que até mesmo uma canção tradicional como "Quem me ensinou a nadar" possa ser utilizada por um desenho animado, e ingressar por esta via na oficina, servindo para a construção de uma canção terapêutica pessoal. Mostra-se necessário, por esse motivo, diagnosticar o estado atual do campo simbólico da criança, e o modo como ele acompanha a dinâmica do sistema musical corrente. Isso porque, como defende Nettl (1976), as canções de qualquer grupo social mudam com frequência, motivados por três motivos: o esquecimento, a criatividade individual e a adequação aos estilos de canção do ambiente.

A noção de que a música muda, que é algo que se desenvolve e produz uma história, resgata a ideia de que ela é uma prática sujeita aos movimentos do mundo humano, às suas variações de sentido, valor e uso. Como resultado, a música, segundo DeNora (2003), passa a ser "uma ação significativamente orientada, ação que toma forma com referência às coisas que o ator percebe, conscientemente ou de alguma forma não-cognitiva, como estando fora de si mesmo" (p. 131). Ou seja, ela se encontra não só no campo do seu próprio desejo e determinação, mas também no horizonte da alteridade, e na interação entre essas duas instâncias. Sendo um fenômeno inter-humano e significativo, a música pode ser portanto considerada um comportamento social (WEBER, 1958), estabelecendo entre seus praticantes uma relação social na medida em que estabelece a probabilidade de que ocorra uma ação social. E ainda que na concepção weberiana as ações sociais sejam as unidades da vida inter-humana, mesmo nos com- 
portamentos estéticos, a música apresenta uma particularidade que torna a relação social ainda mais imprescindível à sua existência. Como ressalta Cage (1990), "uma das coisas que distingue a música de outras artes é que a música exige, muitas vezes outras pessoas. A performance da música é uma ocasião pública ou uma ocasião social” (p. 177). Ela é, na definição de DeNora (2013), "um modo de estar com o outro" (p. 2), pois, além dos comportamentos comunicativos que envolvem ajustes mútuos de orientação e de postura, inclui ações para-musicais como conversas, movimentos e gestos, e até mesmo o uso de materiais e objetos imbuídos de conotações pessoais, históricas e culturais que remetem ao sentido que é dado pelo outro. Já se pode antever as implicações disso para a clínica do autismo, se levamos em consideração o comprometimento das relações sociais, como vimos anteriormente. Para além dos possíveis efeitos terapêuticos, o fato de ser possível engajar indivíduos com esse distúrbio em atividades musicais na oficina já representa um contraponto à ideia de déficit social. E, no entanto, isso não ocorre em um nível mecânico de reprodução de comportamentos aprendidos, mas sim no sentido do compartilhamento intersubjetivo e emocional de uma experiência singularmente humana. Como resume Merriam (1964), a música

existe apenas em termos de interação social; isto é, ela é feita por pessoas para outras
pessoas (...). Ela não existe, e nem o pode, por e para si mesma; deve haver sempre
seres humanos fazendo algo para produzi-la. Em resumo, a música não pode ser defi-
nida como um fenômeno do som apenas, por envolver o comportamento de indiví-
duos ou grupos de indivíduos, e sua organização particular demanda a concorrência
de pessoas que decidem o que ela pode ou não pode ser (p. 27).

Se em qualquer interação entre sujeitos "a energia humana é acumulada, liberada, represada, frustrada e vitoriosa" (DEWEY, 2012, p. 79), ou seja, se conflitos e satisfações são produzidos na medida em que estamos necessariamente frente aos desejos do outro, podemos deduzir que a dimensão social da música necessariamente mobiliza nossa vida psíquica. Portanto, a conexão com o gesto e o movimento, sua dimensão intuitiva e seu aspecto social são possivelmente fatores responsáveis pelos usos da música como uma ação terapêutica. Essa compreensão está no centro das possibilidades de uma intervenção clínica a partir da música, especialmente no caso do autismo, já que, como resume Blacking (1985), a "função da música é potencializar de alguma forma a qualidade da experiência individual e das relações humanas (...) e o valor de uma peça de música enquanto música é inseparável de seu valor como expressão da experiência humana” (p. 31).

A música, enquanto ação que envolve tanto habilidades interpessoais quanto socioculturais, pressupõe um vínculo com o outro enquanto tal, mas também com o Outro, no sentido de 
que a experiência musical compartilhada é indissociável de uma mediação pelo campo musical da cultura, ele mesmo "estabilizado pela repetição, pela memória, pelo hábito, pela permanência que organiza, que cria regras e funções diversas, ainda que estas mudem - e mudam - no decorrer do tempo ou da história de um grupo social" (BRITO, 2007, p. 52). Por isso, os dois campos do social não devem ser pensados em separado, isto é, uma ação interpessoal que não seja cultural, ou uma ação cultural que não seja interpessoal. Como imaginar um encontro em que as partes estabelecem uma comunicação na qual o código não seja compartilhado com os demais, ou que o significado local não seja sobredeterminado pelo conjunto de significações culturalmente acordadas? Portanto, mesmo sendo "importante atentar para o fato de que o grau de estabilidade adquirido por um ou outro sistema de produção musical não deve (nem pode) ser confundido com a Música, ela mesma” (idem, p. 55), fazer música juntos não é jamais um ato separado da história cultural da música.

Como resultado, dois músicos que se juntam para fazer música necessitam um nível de conexão empática para coordenar seus movimentos e interpretar uma composição que pertence a seu grupo social. $\mathrm{O}$ mesmo vale para um encontro informal, uma batucada em que todos cantam as canções que conectam aquele conjunto com o resto da cultura. Mesmo a improvisação livre, que poderia ser considerada uma forma de desvincular-se da história da música com o objetivo de produzir uma composição instantânea, do presente, está culturalmente enquadrada, seja pelos instrumentos, gestualidades, técnicas e estilos empregados, todos eles produtos da cultura. Isso nos permite formular a hipótese de que essas duas faces da música - suas dimensões intersubjetiva e sociocultural - são parte da sua potência terapêutica, ao mesmo tempo capaz de posicionar o sujeito frente a um outro e ao Outro. Quais serão as implicações disso para o conceito de identidade sonora? Como pensar aquilo que seria singular ao sujeito, em um ato que é ao mesmo tempo relacional e coletivo, próprio e alheio, seu e do outro?

Diríamos, então, que a compreensão dos efeitos terapêuticos da música passa por considerá-la uma prática social que ressignifica todas essas dimensões de identidade, alteridade, di ferença e relação. Isso ocorre porque, como enfatizado por Small (1995), a música é um ritual no espaço social, e o ato de musicar 
tes na performance.

De fato, a partir de uma perspectiva histórico-etológica, Dissanayake (2001) sugere que a música ancestral provavelmente era constituída de um pacote de performance multimodal que incluía música, dança e mímica. Tal prática provavelmente se inseria no contexto de rituais comunais dedicados a circunstâncias consideradas importantes e incertas, fazendo recair sobre a música algum propósito imediato como curar um doente, atrair ou domesticar um espírito, demonstrar veneração, alcançar uma transformação espiritual, etc. Esse aspecto ritual certamente acrescenta uma nova dimensão a nossa investigação. Porém, quais seriam as características da atividade musical que lhe conferem esse potencial clínico?

Para responder a essa pergunta, é preciso entender o modo pelo qual os materiais musicais fornecem parâmetros formais que incidem sobre dimensões da experiência subjetiva, tais como percepção, atenção, avaliação, comportamento, sentimento, energia, interpretação, atividade mental, concentração, etc., intensificando, atenuando e modulando suas propriedades. De forma complementar ao argumento sobre os afetos de vitalidade como envelopes da experiência (STERN, 2000), discutido na seção anterior, essa característica permite que a música seja empregada intencionalmente como dispositivo adaptativo a determinada circunstância. Como destaca DeNora (2004), uma música lenta pode ser usada para proporcionar calma e relaxamento em uma situação estressante, uma música estimulante para animar uma festa, ou uma música romântica como fundo sonoro para um encontro sexual.

Todos esses são exemplos de como a música cria territórios (DELEUZE; GUATTARI, 1997), que resultam da circularidade da canção, do afastamento das forças caóticas e da proteção, no interior desse círculo, das forças que compõe uma tarefa. Os sons são os blocos que erguem esse muro, sendo os restantes as demais forças a serem arregimentadas. É assim que uma criança no escuro, tomada de medo, tranquiliza-se cantarolando. Ela anda, ela
pára, ao sabor de sua canção. Perdida, ela se abriga como pode, ou se orienta bem ou
mal com sua cançãozinha. Esta é como o esboço de um centro estável e calmo, esta-
bilizador e calmante, no seio do caos (p. 382).

Da mesma maneira consideraríamos o estudante que cantarola para fazer um dever escolar, a dona de casa que liga o rádio para fazer seus afazeres enquanto o acompanha e o pássaro que canta para assim demarcar seu território. E junto à sua delimitação de um território, "realizam-se dois efeitos notáveis: uma reorganização das funções, um reagrupamento das forças" (idem, p. 129, grifo dos autores).

Um dos exemplo empregados por DeNora (2004) para demonstrar o modo pelo qual a 
música incide na experiência subjetiva é o uso da música em aulas de ginástica. Ainda que canções e temas populares sejam comuns nesse âmbito, a música executada nas academias pode obedecer a regras bastante específicas, sendo a forma mais comum dividida em três partes, com características definidas, em termos de melodia, ritmo, andamento e acompanhamento. A primeira parte, orientada à produção de um corpo aquecido, está baseada em andamentos e intensidades crescentes. A segunda, chamada de núcleo, marcada por ritmos repetitivos e acelerados, com alturas e intensidades elevadas, visa à produção de um corpo que realiza esforços substancialmente maiores, sem consciência da fadiga, com um aumento dos níveis de energia e disposto a realizar repetições sincronizadas de movimentos vigorosos, sem o risco de lesionar-se ou hesitar sobre o que se está fazendo. Por fim, a etapa de relaxamento restitui ao corpo uma consciência de seus gestos, permitindo tanto atender às orientações da voz do professor - que sobressai dos sons que agora vão perdendo a sua intensidade e velocidade - quanto calcular a força e a dinâmica dos gestos. Um corpo que que progressivamente volta a adaptar-se ao ritmo do exterior da sala de ginástica. É nesse sentido que podemos entender como a música possui um poder sobre o corpo, na medida em que ela fornece uma forma estética contra a qual se es truturam processos corporais, sejam eles fisiológicos, como a exaustão ou a excitação; comportamentais, como chutar ou saltar; proprioceptivos, como a consciência dos níveis de dor, cansaço ou prazer; e motivacionais, como a predisposição a uma forma específica de atividade, por exemplo, correr mais rápido, saltar mais alto, caminhar mais devagar, etc. Consequentemente, temos uma verdadeira tecnologia de constituição e organização corporal, que cria e sustenta um corpo ao longo dos 45 minutos da sessão de aeróbica.

Considerada nesse viés, a música pode ser aproximada do conceito de experiência em seu sentido mais forte, isto é, um movimento de transformação subjetiva. Seu caráter de ação difere, por exemplo, do conceito de comportamento, que pode ser referido a uma rotina padronizada de condutas e à possibilidade de observação descritiva. Segundo Bruner (1986), essa distinção evidencia uma dificuldade epistemológica, já que a experiência não pode ser conhecida de uma maneira definitiva, ainda que inferências possam ser feitas a partir das expressões do sujeito. Nesse sentido, o que caracteriza a experiência, de acordo com Dewey (2012), é tanto uma singularidade quanto uma unidade e um enredo que a conduz de um início a um final, que a distingue daquilo que veio antes e depois. É aí que ela se distingue do plano mais amplo da vida como um fluxo uniforme e ininterrupto. Tanto coisas insignificantes, como uma refeição em um restaurante, uma situação marcante na vida de alguém, um acidente evitado por pouco 
ou o rompimento de uma relação afetiva, podem ser experiências, no sentido que as chamamos vulgarmente de "experiências reais". Elas são reais, como defende Turner (1986) no sentido de que implicam uma verdadeira formação ou transformação de nós mesmos e do nosso mundo, "sequências isoláveis e distinguíveis de eventos externos, e respostas internas a eles, tais como iniciações em novos modos de vida” (p. 35).

Se a dimensão transformadora da experiência está presente na vida cotidiana, ela não deveria ser reduzida ao domínio da arte ou do entretenimento, sendo melhor compreendida na "continuidade da experiência estética com os processos normais do viver" (DEWEY, 2012, p. 70). Surge então a possibilidade de pensar as produções artísticas, mais que expressão de ideais de beleza, como uma forma propriamente humana de adaptação ao ambiente. Assim como o pássaro constrói o ninho e o castor o seu dique, segundo a pressão com que as forças orgânicas cooperam com os materiais externos, a mesma necessidade nos ajuda a compreender, como defende esse autor, a construção do Partenon. Pois, se bem os homens contam com características que os tornam únicos no reino animal, como a consciência de si e das relações naturais de causa e efeito, o que une todos esses processos em torno à ideia de arte é a resposta ao mesmo im pulso. A dimensão estética da experiência, desse modo, não se encontraria enraizada em formas transcendentais, mas nos modos de vida disponibilizados pelo encontro com o meio. Estaria afincada nos processos vitais de expansão das energias do organismo, constantemente em busca de um equilíbrio estável com as condições dinâmicas do ambiente no qual está inserido. No processo do viver, alcançar um período de equilíbrio também marca o início de uma nova relação com o meio, quando outras adaptações deverão ser feitas e conduzirão a um novo desequilíbrio, em uma sucessão de mudanças.

Ainda para Dewey (2012), essa dinâmica instável da experiência implica uma acentuação da vitalidade. Pois, em lugar de encerrar o sujeito em seus próprios sentimentos e sensações, a experiência possui essa capacidade de abri-lo ao mundo dos objetos e dos acontecimentos. E da mesma forma que o animal está "plenamente presente, inteiramente participante em todos os seus atos: nos olhares cautelosos, no farejar sensível, no espetar abrupto das orelhas" (p. 82), a arte recupera ao homem essa "presença” no mundo, integrando-o ao seu ambiente e tornando-o plenamente vivo. Se a arte é capaz de remeter a esse estado de atenção à realidade que nos cerca, é porque ela funde os sentidos com o movimento, e desse modo pode ser empregada também com finalidades terapêuticas. Como resume Barcellos (2009), nas terapias através da arte 
a pessoa vivencia uma situação que pode envolvê-la e (re)ativar os sentimentos e emoções que acompanharam essa situação. Nestas terapias o paciente expressa seu mundo interno através de materiais que se constituem como intermediários dessa expressão, ao mesmo tempo em que estes se põem como possibilidade de mudança. Uma mudança de ação na utilização do material é uma oportunidade de mudança interna (p. 222).

Logo, podemos acrescentar às propriedades da música que subjazem à sua ação terapêutica uma capacidade de transformação subjetiva. Para entender as especificidades desse movimento no campo da escuta, Didier-Weill (1997) decompõe o ato de ouvir música em quatro tempos lógicos diferentes, ou seja, definidos mais por uma simultaneidade que por uma sequência. Para este autor, em um primeiro momento, aquele que ouve funciona como um sujeito ouvinte, ao qual a música afeta como se carregasse uma resposta a uma questão que este sujeito, somente ouvindo a música, toma conhecimento de que já portava. Isto é, na presença da música, nota a existência de uma questão inconsciente que o habitava como Outro, sem que o soubesse. Essa questão revela a existência de uma falta sobre a qual a audição nada diz, pois somente aponta diretamente na medida em que o sujeito é dito por essa falta. Por outro lado, indica, ao mesmo tempo, sua divisão enquanto sujeito que produziu a música em resposta à questão do ouvinte. Ainda neste primeiro tempo lógico, o sujeito ouvinte espera da resposta que lhe fornece a música algo mais, o objeto a, causa de seu desejo e, por isso, segue este sujeito, que ocupa uma posição de sujeito suposto ouvir enquanto ouve a sua questão, ao longo do circuito pulsional.

O segundo tempo lógico do ato de ouvir corresponderia a um segundo modo de separação entre sujeito e Outro, na medida em que esta é percebida a partir de outra perspectiva. Após perceber a possibilidade de um sujeito que produziu uma resposta à sua questão, o sujeito ouvinte nota que a falta que o habita como Outro também é a dele próprio. Surge então um ponto de torção deste circuito pulsional: se antes o ouvinte se reconhecia como tal diante da resposta que a música lhe trazia, agora é pela música que ele será reconhecido, isto é, a música torna-se uma questão que o convoca como sujeito a respondê-la. Este segundo tempo é o momento em que aparecem, portanto, um novo sujeito e um novo objeto, correspondendo ao "ponto em que tudo se passa como se nós mesmos produzíssemos as notas que nos atravessam" (p. 95). É preciso insistir sobre este ponto e seu condicional: ainda que não seja o ouvinte o produtor da música, tudo se passa como se fosse dele mesmo a sua autoria. É nesta segunda perspectiva de separação que este, agora enquanto sujeito, pode perceber a falta que se situa no Outro. 
Em um terceiro tempo, esse ouvinte, agora sujeito produtor da música, dirige-se a um novo outro, o sujeito suposto ouvir, que já não é mais o Outro do ponto de partida. Com ele, o sujeito vai se identificar, conduzindo a uma dupla disposição em que o sujeito é, ao mesmo tempo, aquele que fala e aquele que ouve a música. Mas não chegamos ao final pois existe, ainda, um ponto derradeiro da pulsão, que não coincide com o ponto de partida já que a pulsão não retorna ao ponto de onde partiu. Trata-se, mais que nada, de um ponto de não retorno. Nesse ponto, ocorre uma dupla suspensão: do tempo e da pulsão. A hipótese que Didier-Weill nos deixa é que ali se celebra o ato fundador do inconsciente na separação mais primordial, arrancada do Real e introduzida no sujeito. Ainda que isso não ocorra todo o tempo ou, pelo menos, em todas as audições, Didier-Weill nos mostra que, chegando neste quarto tempo, o sujeito ouvinte percebe que durante todo esse trajeto insistiu na busca de algo que é inatingível e em torno do qual só fez circular ao percorrer o circuito pulsional. Desta forma, será possível perceber que o que lhe é faltoso não é propriamente esse objeto, mas a hiância existente no Outro. Tal ponto é, para Didier-Weill, um ponto de dessexualização máximo, um ponto sublime no sentido de sublimação tal como entendido no contexto psicanalítico.

Conhecendo o movimento da atividade pulsional, é possível entender que essa dimensão transformadora não está separada do aspecto social da música, ou seja, que ela se encontra no campo da relação entre o sujeito e a alteridade. $\mathrm{E}$ tal movimento possivelmente pode ser extrapolado do contexto da escuta, tal como analisado acima, para o plano da experiência musical completa, para o o ato de musicar. Encontramos esse mesmo sentido nas seguintes palavras de Rousseau (apud LÉVI-STRAUSS, 1993):

Quanto à música, nenhuma forma de expressão, parece, está mais apta a recusar a du-
pla oposição cartesiana entre material e espiritual, alma e corpo. A música é um siste-
ma abstrato de oposições e de relações, alterações dos modos de duração, cuja execu-
ção ocasiona duas consequências: primeiramente a inversão a relação entre o eu e o
outro pois, quando ouço a música, escuto-me através dela; em segundo lugar, por
uma inversão da relação entre alma e corpo, a música vive em mim (p. 47, grifos do
autor).

Seja no fenômeno da escuta, seja na prática musical, a música apresenta uma potência de transformação em função dos movimentos de torção subjetiva que deslocam o sujeito de si, ao longo do seu eixo de alteridade, entre o outro e o Outro. Logo, um dos fatores mais interes santes da música é que, ao representar para o sujeito outros modos de ser, ela age não só no campo das percepções e das emoções, mas sim na própria construção ontológica do real. Quem sou eu? Quem é outro? Que lugar ocupo em meu grupo social? Em que lugar estou nesse momento? Todas essas são questões que são respondidas de alguma maneira pela música. 
Como comenta DeNora (2013), "a música não faz as coisas acontecerem. Em vez disso, a música é em si uma prática transformadora: ao musicar, tornamo-nos aquilo que estamos fazendo" (p. 141). Torno-me cantor quando canto, e parte de um todo maior quando faço isso em grupo. Novas identidades são apropriadas por mim quando escolho as canções pertencentes a um determinado grupo, e não são apenas elas, mas também eu mesmo, que apresento aos demais quando as canto. No caso das crianças, isso pode ser acompanhado em suas práticas musicais, que, conforme Brito (2007), "além de exercícios de expressão, de aquisição e de ampliação de conhecimentos musicais, são oportunidades para vivenciar questões essenciais, referentes ao 'ser e estar' no mundo, consigo mesmo e com o outro, em cada fase, em cada momento" (p. 244).

Evidentemente, a extensão do que pode ou não ser definido pela música depende da posição que lhe é dada no simbolismo particular de cada cultura. Os índios Suyá que vivem no Parque Indígena do Xingu (Mato Grosso), por exemplo, extraem suas orientações temporais das músicas que estão sendo tocadas naquele momento. “Tradicionalmente, não havia relógios, não havia estações, não havia direções, e a música era para encontrar essas coisas: a música começa a estação chuvosa, a música termina a estação chuvosa, seja se está seco ou úmido" (SEEGER, 1987, p. 74). Já para os Kaluli da Nova Guiné, (FELD, 1982), essas informações são fornecidas pela presença ou ausência de aves, que são sentidas pelo canto, ou do volume dos rios e quedas d'água, determinado pela intensidade do seu ruído. É curioso, no entanto, que esses índices, supostamente naturais, são também percebidos de uma maneira cultural, já que tanto as cachoeiras são consideradas um excelente acompanhamento para cantar, e que na mitologia desse povo os sons dos pássaros e as canções humanas são análogos e permeáveis entre si.

O que esses casos demonstram é que a música pode fornecer as coordenadas espaçotemporais nas quais os sujeitos consideram estar e que utilizam para organizar e orientar as suas ações. Em um certo sentido, seria como se o território e o ciclo dos anos fossem como um concerto, que cria o tempo e o espaço por meio do som e do movimento. Talvez por esse motivo, a música é um dos elementos mais comuns e importantes de rituais realizados em momentos fundamentais da vida do indivíduo, como nascimentos, iniciações, casamentos, mortes, etc. (TURNER, 1985). Tais rituais cumprem uma função não menos importante na estabilização e ajuste da estrutura social desses grupos, resgatando-os da zona de indeterminação potencial que emerge das mudanças e contradições nas relações sociais. Nessas performances de transformação, observam-se rupturas, crises, cisões e reintegrações sociais, a substância daquilo que 
esse autor chama de "drama social", e que constitui o motor pelo qual a comunidade continuamente se redefine e renova a si mesma. Rituais coletivos são, portanto, experiências culturalmente organizadas que norteiam o grupo não só quando uma criança se torna adulta e um casal se torna um matrimônio, mas também quando antigos aliados se tornam oponentes e novas alianças são concretizadas, facções mudam de tamanho e poder, ou lideranças ganham ou perdem sua legitimidade. Em todos esses casos, o ritual fornece os elementos materiais e ideológicos que guiam a transição de um estado para o outro, renovando a vitalidade do indivíduo e da sociedade, confirmando suas respectivas flexibilidades de se transformar.

É possível, portanto, que esse aspecto transformador do sujeito e de seu mundo esteja implicado nos usos clínicos da música e explique seus efeitos terapêuticos. De fato, em muitas sociedades não-ocidentais, a música não é considerada uma forma complementária de tratamento, mas um elemento fundamental na atenção primária à saúde. Segundo as crenças e tradições desses povos, a música atua como agente diagnóstico, prognóstico, etiológico, de tratamento e/ou cura sob uma multiplicidade de formas e preferências expressivas (CHIANG, 2008). Muitas vezes, essas práticas musicais de cura incluem, além dos instrumentos e demais objetos de produção de som, uma série de outros elementos expressivos tais como trajes especiais, máscaras, pinturas, danças, etc. São rituais que integram arte musical, visual e coreográfica, exigindo uma intensa preparação e participação coletivas. Nesse sentido, podemos entender que as sessões da oficina de música também se favoreceram dessa intermodalidade para potencializar a participação das crianças e, da mesma maneira, seu efeito terapêutico.

Muitas vezes, a associação entre tratamento e transformação por meio da música é evidente, como no caso dos Piman (BAHR; HAEFER, 1978), para quem o objetivo do tratamento musical não é fazer com que o paciente fique "bom" como antes, mas sim transformá-lo em uma pessoa diferente do que era antes. Essa ideia pode ser conduzida à discussão a respeito do autismo, vinculando a noção de cura mais à retomada das funções do desenvolvimento que à supressão dos efeitos da síndrome. De qualquer forma, trata-se de uma ideia central no argumento mais geral de que os efeitos terapêuticos da música não se restringem ao momento da sua aplicação, mas que se estendem para a vida cotidiana dos pacientes. Para Brandalise (2001), a experiência criativa com a música permite não apenas a modificação de comportamentos cristalizados, mas que se produza uma transformação subjetiva, na medida em que a experiência de mudança se transfere para outras situações da sua vida pessoal. E possivelmente por ter uma presença tão disseminada em nossas vidas, a música pode ter uma ação terapêutica 
ainda mais intensa, se considerarmos também aqueles processos que não são clinicamente orientados, mas adotados pelo próprio sujeito, como escutar uma música para se acalmar ou se animar (DENORA, 2011). Isso ocorre porque, como lembra Dissanayake (2001), a música "continua a oferecer consolo emocional e um senso de transformação individual, mesmo quando o comportamento musical pode ser expresso como a escuta solitária da performance registrada de outra pessoa” (p. 169).

Música como musicalidade, conhecimento intuitivo, jogo, território, ação social, experiência e transformação. Nesta seção, pudemos acompanhar diversas ideias que pretendem explicar como a música produz efeitos terapêuticos. Resta-nos acompanhar mais detalhadamente o modo pelo qual tais efeitos são produzidos, em função das dimensões da narrativa, ritmo, corpo, imitação e identificação, assim como elas são vividas nas sessões da oficina.

\subsection{Narrativa}

Algumas das intervenções realizadas caracterizaram-se pelo engajamento dos motivos dos participantes em formas narrativas. Apesar terem uma eficácia variável, em função do quanto entravam em conflito com a inflexibilidade de alguns deles em permitir a entrada de elementos alheios em suas histórias, elas apresentaram resultados encorajadores. A encenação da morte do jacaré por Pablo (Fig. 20) e o desenvolvimento da história do Chico Bento por William (p. 52) são casos que chamam a atenção nesse aspecto. Ambos tiveram um impacto relevante na trajetória de seu tratamento, e a inclusão de movimentos estereotipados em uma série narrativa mostrou que era possível dar-lhes um novo sentido, recuperando as intenções por trás de cada gesto. Para discutir as possibilidades clínicas ligadas à narrativa, primeiramente nos aprofundaremos em suas características e em sua relevância para os processos de constituição subjetiva e de relação com a alteridade. Em seguida, o modo como pessoas com autismo elaboram narrativas é discutido, e as dificuldades experimentadas por eles nesse domínio são apresentadas. Essas considerações orientam, por fim, a discussão sobre três formas de intervenção clínica com o emprego de formas narrativas, tanto no que diz respeito às estratégias pensadas aos participantes da oficina quanto em outros casos apontados pela literatura.

De acordo com Bruner (1991), a narrativa é um relato de eventos que ocorrem no tem- 
po. Apesar de incluir ações aparentemente não-temporais, fantásticas ou do passado, a sua diacronicidade é o primeiro requisito para a organização de acontecimentos particulares em um tempo que não é cronológico, mas humano (RICOEUR, 2012). Outro elemento fundamental da narrativa é que esses acontecimentos se relacionem aos estados intencionais de seus personagens. Mesmo animais ou objetos não agentes adquirem estatutos intencionais, e eventos físicos, como o clima e a geografia, afetam os estados intencionais dos protagonistas. Isso cria uma relação flexível entre as intenções e as ações que, na medida em que não oferece uma explicação causal do motivo de um personagem agir como o faz, deixa o relato narrativo aberto à interpretação do seu sentido. A aceitabilidade de uma narrativa, portanto, não depende de sua referência à realidade, mas sim às expectativas culturais do grupo em que está localizada. Ainda que apresentem dilemas humanos universais como as aventuras de uma viagem, um inocente que é defraudado, a defesa frente um ataque, um problema que deve ser contornado, etc., elas implicam uma normatividade prévia de práticas, valores e costumes. Mesmo as brechas a essa norma são altamente convencionais e reconhecíveis, legitimando e reforçando o cânone.

A “Música assustadora” (Fig. 12) é um exemplo de estruturação narrativa ocorrida na oficina. Na medida em que os diferentes instrumentos e recursos sonoros vão sendo introduzidos e a tensão dramática aumenta, todos compartilhamos um estado emocional crescente. $\mathrm{O}$ tema do medo, um dos mais frequentes, faz parte também do cânone infantil, como podemos depreender do sucesso que histórias e filmes de terror desfrutam entre esse público. No contexto de nossa prática, ele demonstrou seu apelo na "Música assustadora" ou o motivo musical do filme "Tubarão" (Fig. 26), que eram solicitados em diversos encontros. O motivo dessa preferência é algo que ainda não está claro. Será que as crianças querem o terror para lidar com questões subjetivas, expressando uma espécie de terror interno? O que podemos dizer com segurança é que a qualidade da encenação da narrativa teve um papel fundamental na determinação da ativação emocional nos membros do grupo. É evidente que o grito de bruxa de Beatriz, ou a tensão da improvisação, produziram uma tensão muito maior que a parlenda da bruxa no castelo, o que resultou em performances muito mais convincentes.

Assim como na "Música assustadora", a eficácia da narrativa não depende apenas de seus aspectos linguísticos e verbais, mas também de eventos ligados ao som e ao movimento (GRATIER; TREVARTHEN, 2008). Ao contar uma história, quem narra interpreta com inflexões e cadências vocais complexas e sutis, acompanhadas por gestos coordenados e movimentos corporais que expressam emoções. Para engajar a audiência, o narrador monitora o flu- 
xo de atenção entre os espectadores, regula a construção das tensões e resoluções, acelera ou reduz o andamento e reforça a construção linguística dos temas, motivos e enredo com a dança e a música que a acompanham. O resultado é um compartilhamento recíproco do fluxo de experiências do Outro no tempo interno de cada um (SCHUTZ, 1976).

A música pode realçar e ressignificar os elementos de uma narrativa, como faz a trilha sonora terapêutica. No trabalho clínico, ela demonstrou poder ser empregada com esse mesmo propósito, acompanhando e moldando as narrativas desenvolvidas pelo grupo. É esse o seu uso nas improvisações da ida de Pablo ao hospital (p. 67-68) ou da "Ilha do Medonho" (p. 50-51). É relevante que, no primeiro caso, os sons oferecem uma possibilidade de dramatização que incide no modo de narração dos eventos, que se tornam mais vívidos e detalhados, reforçando a experiência das emoções e sentimentos envolvidos. A situação toda é reelaborada, e o desfecho positivo pode ser valorizado, transformando a história em um "susto". No segundo caso, os elementos sonoros e musicais também acompanham a narrativa, mas desta vez permitindo criar uma história na qual as crianças podem vivenciar suas fantasias de uma maneira que as envolve e conduz. Certamente, é essa propriedade que ajuda William a desenvolver a história ou aceitar que os demais a componham junto com ele. E a música atua como uma trilha sonora terapêutica, na medida em que proporcionamos a elas um meio facilitador de processos de identificação e de significação ao longo da narrativa, tornada real com o auxílio do som e da música.

Essas variações de níveis de intensidade, seus contornos de vitalidade, são aquilo que define e encadeia os elementos da sequência narrativa, conferindo-lhe uma forma dinâmica global. Tais linhas de tensão dramática não se referem, portanto, apenas a atos isolados, mas também a eventos conectados, nos quais os contornos de vitalidade atuam como envelopes proto-narrativos (STERN, 1992). Nessa perspectiva, a coreografia da canção "Cocoricó" (Fig. 27) também possui um formato narrativo, que sobe, desce, e volta a subir ainda mais, antes de explodir e cair em uma rápida queda ao piso.

Sendo a performance narrativa uma expressão multimodal, ela remete às primeiras etapas do desenvolvimento da linguagem e das interações entre bebês e seus cuidadores. No início, essas interações são compostas por narrativas sem palavras, compostas por movimentos expressivos que ativam uma imaginação narrativa compartilhada. A passagem do manhês a formas narrativas mais complexas se dá aproximadamente após o sexto mês, quando o discurso melódico é gradualmente substituído por uma fala informativa, cuja referência é menos aos es- 
tados internos que a eventos no mundo exterior (GRATIER; TREVARTHEN, 2008). Isso implica uma nova organização das formas narrativas, deslocadas da interação interpessoal ao engajamento cooperativo com relação aos objetos, que são a marca da transição da intersubjetividade primária à secundária (TREVARTHEN; HUBLEY, 1978). O papel das canções infantis no encontro da criança com os outros não pode ser negado, na medida em que elas ativam a percepção de que uma ampla gama de parceiros compartilham a mesma cultura, tácita, incorporada, muito maior e mais antiga.

Nesse sentido, é possível identificar um processo de acúmulo narrativo (narrative accrual), no qual as narrativas são repassadas, recriadas e redistribuídas a cada geração. Trata-se um modo distinto daquele de ciência, cujo acúmulo de conhecimento ocorre pela derivação de princípios gerais, relacionando descobertas particulares a seus paradigmas contemporâneos. Uma vez compartilhadas culturalmente, as formas narrativas obtém exterioridade e poder coativo como uma representação coletiva (DURKHEIM, 1994). Essa capacidade de acumular histórias de acontecimentos do passado em uma estrutura diacrônica que lhes confere uma continuidade no presente está, de acordo com Bruner (1991) na base da formação de uma cultura. E ao fazê-lo, cada grupo estabelece modelos narrativos para descrever o curso de uma vida, não apenas no sentido de um estoque de representações ideais, como heróis, mártires, vilões, etc., mas de elementos formais combináveis, que podem ser empregados pelos membros na construção de suas próprias narrativas de vida.

As formas narrativas, portanto, não se referem apenas à organização de acontecimentos particulares que expressam os estados internos de personagens abstratos. Elas dizem respeito à realidade concreta de indivíduos reais, que as usam para estruturar suas experiências pessoais, organizar suas memórias e dar propósito aos eventos de uma vida. Não no sentido de dizer o bem e a verdade, mas no sentido ético de um bem-dizer (LACAN, 1985). Ao posicioná-los em uma sequência temporal, as vicissitudes das intenções humanas que são objeto da narrativa servem para justificar o presente, mas também para direcionar esses eventos ao futuro. "No final", afirma Bruner (2004), "nos [tornamos] as narrativas autobiográficas pelas quais 'falamos sobre' as nossas vidas” (p. 694). Mas essa construção narrativa de realidade não se exprime em termos causais e lógicos, porque conserva a instabilidade hermenêutica de uma leitura interpretativa dos eventos. Essa condição torna os relatos narrativos suscetíveis a influências culturais, interpessoais e linguísticas, e explica porque intervenções no campo da palavra e da cultura, como recontar, reelaborar e narrar uma história, podem ter efeitos tão profundos na narrati- 
va de vida de uma pessoa.

Para Freud (1914/1996b), a possibilidade de narrar permite ao paciente não apenas descarregar seus afetos na situação clínica, mas elaborá-los e dar-lhes um sentido, pois o trabalho de elaboração conduz à integração das excitações que afetam o psiquismo, reduzindo suas propriedades patogênicas ao estabelecer novas conexões associativas. A narrativa se encontra, portanto, implicada também nos processos intrapsíquicos de transição entre o registro econômico e o simbólico. Nessa chave, Freud reconhece que a ausência ou insuficiência da elaboração são as responsáveis pelo adoecimento, tanto na neurose quanto na psicose, quando o afeto não pode ser representado e termina derivando em um sintoma. Essa observação remete à proposta de Lévi-Strauss apresentada anteriormente e é fundamental para clínica dos distúrbios do desenvolvimento. Kupfer (2010), analisando o modo como a escrita alfabética poderia servir à criança com transtornos do desenvolvimento como uma via de estruturação psíquica, a partir da inscrição de traços com caráter subjetivante, mostra como estes podem ser acompanhados por processos de construção, reconstrução ou rehistorização do sujeito. $\mathrm{O}$ caso do menino F. apresentado por ela é emblemático: frequentando desde os 2 anos uma escola regular, F. conserva sua posição autista na relação com os outros, porém a escolarização facilita a aquisição da escrita. Sua atenção é logo atraída pelo tema das pedras preciosas, e ele demonstra um amplo conhecimento de esmeraldas, ametistas, rubis, etc. A primeira frase escrita do garoto contraria quase tudo que esperamos de uma criança com autismo: "Eu sou um diamante". Não só estão ali implicados o uso do pronome pessoal e da metáfora, considerados uma dificuldade nessa condição, quanto aquilo que podemos chamar de narrativa de si. O sujeito ali enuncia algo que não diz respeito a nada mais que não seja ele mesmo e seu desejo.

A carta que Mathias escreve no atendimento individual e me entrega em seguida é uma construção desse tipo (Fig. 29). No meio da larga mensagem, que descreve a cena da grupo e a redação do próprio texto, a primeira frase encontra na conclusão uma ordem, um pedido: "Veja o que eu fiz agora". Ponto. Será esta uma história pessoal?. As atividades no atendimento com Paula, a oficina, o tempo que falta para começar, a guitarra. Todos eles são elemen tos que compõe esse plano do desejo, as coordenadas de seu mundo e daquele dia, no qual, como ele diz, "estamos juntos".

Não obstante, estudos indicam que pessoas com autismo apresentam dificuldade na construção de narrativas ricas, complexas, coerentes, e que carecem de entendimentos compartilhados sobre eventos e experiências por meio da narrativa, chegando a não ter consciência 
que narrar é um mecanismo para organizar e comunicar experiências (BRUNER; FELDMAN, 1993). A carta de Mathias aparenta justamente o contrário: conscientemente ou não, ela apresenta uma espécie de agendamento de acontecimentos atuais e futuros. Já as questões de linguagem do documento podem ser interpretadas em função dos sintomas do autismo, sempre tendo em conta que se trata de uma criança de quatro anos, com uma aquisição recente dessa habilidade. Tager-Flusberg (1995), por exemplo, usando um livro, não encontrou ocorrências de linguagem causal nas narrativas construídas por crianças com autismo, resultando em uma menor integração dos acontecimentos narrados e um encadeamento menos coerente do discurso. Em um outro estudo, Tager-Flusberg e Sullivan (1994) usaram outro livro de imagens, com histórias de engano (deception) e astúcia (trickery), pedindo que as elas contassem uma história. Crianças com autismo tiveram um desempenho semelhante a outras da sua mesma idade mental com relação ao uso de linguagem causal, mas tiveram dificuldade em responder a perguntas sobre os pensamentos e emoções dos personagens. Segundo Capps, Losh e Thurber (2000), crianças com autismo tiveram a mesma frequência apresentada por crianças com retardo mental no emprego de estruturas gramaticais complexas, o que dificulta a compreensão do que é específico para essa síndrome caso a atenção esteja voltada apenas para os aspectos linguísticos da narrativa. A revisão da literatura indica que existe uma dificuldade de usar formas gramaticais complexas para construir conexões episódicas e temáticas, mas que a principal dificuldade é a avaliação dos motivos e intenções dos personagens, além do seu encadeamento em uma ordem coerente. Durante as sessões da oficina de música, diversas tentativas de Mathias em narrar um acontecimento específico apoiam essa noção. $O$ episódio em questão era um banho de mangueira que ele afirmava ter tomado na creche. Ao pedir mais informações sobre quando isso havia ocorrido, Mathias não conseguia prosseguir com seu relato, mesmo com perguntas que possivelmente o auxiliariam a se lembrar, como a época do ano, se era frio ou calor, etc. Nas vezes em que a história surgiu, no entanto, poucas vezes pudemos avançar na sua narração, lançando dúvidas se se tratava de um problema de memória, ou se havia outro mecanismo que obstaculizava a dinâmica do relato.

Losh e Capps (2003), em uma comparação entre crianças com autismo e um grupo controle com desenvolvimento típico, avaliaram narrativas elaboradas a partir de um livro de imagens e suas próprias narrativas pessoais, encontrando uma boa leitura das histórias, mas dificuldades em narrar suas experiências. Com relação ao uso de estruturas gramaticais complexas, como orações coordenadas, complementos verbais, orações adverbiais e voz passiva, as cri- 
anças com autismo apresentaram uma menor frequência delas em suas narrativas pessoais, mas não naquelas a partir do livro de imagens. As crianças do grupo controle, por sua vez, usaram duas vezes mais estruturas complexas na narração de suas histórias pessoais que nas do personagem do livro. Com relação às avaliações feitas pelas crianças de suas próprias narrativas, os pesquisadores mediram a frequência e diversidade de expressões de causalidade de eventos e comportamentos, reconhecimento de emoções ou estados internos, negações, hesitações, onomatopeias e efeitos sonoros, além de observações subjetivas e intensificadores. Nesse aspecto, as crianças do grupo controle apresentaram maior frequência e diversidade de avaliações no contexto da narrativa pessoal que as crianças com autismo, mas os resultados com o livro foram semelhantes em ambos critérios. Enquanto estas não apresentaram variação numérica com relação aos dois contextos, aquelas empregaram duas vezes mais avaliações em suas narrativas pessoais que nas narrativas do livro de imagens. Esses resultados evidenciam uma vulnerabilidade de crianças com autismo às dificuldades em narrar experiências pessoais, e indicam que elas podem beneficiar-se de práticas que estimulem e desenvolvam essa habilidade.

$\mathrm{Na}$ oficina de música, soma-se à noção de narrativa de si ao menos duas outras formas de intervenção: o desenvolvimento de motivos musicais e a dramatização e ressignificação de estereotipias. Ambas se referem à mesma estratégia clínica de dar um sentido distinto a um comportamento repetitivo por meio da sua inserção em uma sequência narrativa. Uma se refere exclusivamente a materiais musicais, enquanto a outra abrange outras modalidades de expressão. Um exemplo desse primeiro tipo de intervenção pode ser identificado no desenvolvimento da célula rítmica que tanto atraiu William logo nas primeiras sessões (Fig. 5). Como vimos, ela aparecia de uma forma reiterada que impedia a realização das atividades e mesmo a sua participação. Do ponto de vista musical, poderíamos dizer que se tratava de uma dificuldade de desenvolver a célula em um motivo ou um tema maior, já que sua repetição em ostinato, sem conexão com qualquer outra ideia, não chegou a produzir verdadeiras figuras ou frases, limitando seu sentido musical.

Uma das noções que podem dar uma pista sobre a repetição da figura rítmica por William é a idée fixe, um tema recorrente que aparece de forma obsessiva em diferentes movimentos de uma composição. Empregado pela primeira vez por Berlioz na "Symphonie fantastique", ela aparece no formato de uma melodia, apresentada pela flauta e o primeiro violino, com um contorno nítido que ascende lentamente para depois desabar. Apesar do nome, as reiterações posteriores não indicam qualquer fixidez, sendo apresentadas por grupos de instrumentos 
distintos, com andamentos, acompanhamentos e dinâmicas variadas. No programa apresentado na premiére por Berlioz (1830), a peça é apresentada como um episódio da vida de um artista, que se apaixona por uma figura feminina e sofre os tormentos e a loucura de não ser correspondido. Ainda segundo o programa, a imagem da amada só se apresenta nos devaneios do artista ligada a um pensamento musical, cuja melodia e modelo o perseguem sob a forma de uma ideia fixa.

Apesar de a idée fixe e a figura de William possuírem diferenças quanto à sua complexidade e variabilidade, elas apresentam duas características em comum: seu caráter repetitivo e de fixidez. Isso é ressaltado pela frequência com que são apresentadas, surgindo em meio a desenvolvimentos musicais com o quais não parecem ter qualquer conexão, muitas vezes interrompendo o material que está sendo tocado e impedindo que o mesmo chegue a uma conclusão, ou até forçando o seu desfecho. Para Bernstein (1961/2004), na "Symphonie fantastique", a idée fixe "é a amada de Berlioz, é ela quem o deixa desesperadamente doente de amor, ela as sombra a sinfonia. Para onde quer que [a sinfonia] vá, ela a invade, interrompendo, retornando em intermináveis formas”. Essa poderia ser uma descrição da insistência de William na fixidez da célula rítmica.

A intervenção preparada para manejar clinicamente a reiteração da figura, isto é, a sua derivação na apresentação da parlenda "Um, dois, feijão com arroz" (p. 28), mostrou-se ineficaz. A variação, até esse ponto, era apenas timbrística, de acordo com os diferentes instrumentos usados na sua repetição: primeiro com um tambor e um apito, depois dois tambores, um apito e chocalhos. Uma aproximação poderia ser feita com o "Boléro" de Ravel, no qual um único motivo melódico é repetido indeterminadamente empregando diversas combinações de orquestração. Mas, ao contrário dessa peça, o desenvolvimento da figura é nulo, no sentido de que não fomos capazes de conduzir aquele material à formação de um motivo. É na tentativa do próprio William de introduzir a figura na apresentação da canção "Banho é bom" (Fig. 6) que a estereotipia acaba. Como acompanhamos na transcrição, a adequação ao ritmo da canção - com o objetivo de adaptá-la à sua pulsação - está relacionada a essa ruptura. Isso não o impede de continuar com as descargas de agressividade nos instrumentos ou pessoas, mas o tira daquela saturação, e possibilita que seja recuperada uma interação com o resto do grupo que não se limita mais à apresentação daquela figura.

Apesar de a tendência à repetição e preservação da igualdade de objetos e situações ser um dos elementos clássicos do diagnóstico de autismo, não está claro se é esse o motivo pelo 
qual a criança mantém esses comportamentos. Já com relação às estereotipias, Laznik (1997) propõe que elas possuem a finalidade de descargar a energia motora, provocando uma sensação física agradável. Logo, seriam gestos que, no curso do desenvolvimento, perderam o valor comunicativo que em algum momento chegaram a adquirir, sendo reduzidas às ruínas desses atos que não finalizaram a sua constituição, reduzindo-se a uma autoestimulação. A repetição da figura rítmica de William lança algumas dúvidas com relação a essa proposição. É possível que elas correspondam a descargas motoras, considerando o modo como ele as realiza, com uma grande intensidade. Mas por que, então, ele constantemente chamaria a nossa atenção para sua performance? E porque ela desparece após a sua modulação e inclusão em uma série musical distinta? Há alguma especificidade musical nesse deslocamento?

Talvez seja oportuno recorrer à diferença estabelecida por Tustin (1975) entre objetos autistas, aos quais a criança permaneceria ligada de uma maneira estereotipada, e as figuras autistas, isto é, as práticas ou ações corporais estereotipadas. Com relação ao trabalho clínico, essa segunda dimensão é a que se tem em mente em uma intervenção que incide sobre o comportamento de William de correr ao redor do grupo sem parar. Se atentamos para uma comparação transmodal, trata-se da mesma noção de ideia fixa, porém existe uma diferença importante. Por estar inscrita em um campo da linguagem corporal, essa conduta apresenta uma possibilidade ainda maior de conexão a outras modalidades de significação. É nesse sentido que é possível sugerir que o corpo de William se transforme na locomotiva de um trem, que o deslocamento no espaço do salão se insira em uma narrativa e que a corrida informe seja a matéria de uma brincadeira (p. 49-50). A ideia não é fazê-lo parar, mas sim criar um envelope narrativo que regule a dinâmica do movimento e, ao mesmo tempo, permita que as demais crianças entrem no jogo. Com as mãos dadas, ele agora deve fazer fazer paradas nas estações, aguardar os passageiros subir ou descer, fazer sons de apitos e de engrenagens, e transportar mercadorias, inclusive buscando outros trajetos para isso. A princípio, esse novo contorno de vitalidade encontra alguma resistência em ser adotado, mas logo estamos todos nos divertindo.

Essa estratégia poderia ser denominada de dramatização e ressignificação de estereotipias, e está vinculada à confecção de um sentido aos movimentos em função de associações pela forma, intensidade e regulação de tempo. Podemos encontrar, na análise de uma criança por Rodulfo (1999), elementos similares a essa abordagem. No momento em que chega ao primeiro atendimento, L. não falava praticamente nada, produzindo apenas algumas ecolalias de falas da televisão que não apresentam intencionalidade comunicativa, apesar da sintaxe correta, 
o que leva a família a buscar sem sucesso uma reeducação fonoaudiológica. Seu único interesse era acompanhar o movimento de rotação de objetos como as pás do ventilador e as rodas de um veículo, e sua atividade era reduzida aos movimentos de giro, caminhando em círculo, mas sobretudo fazendo as mãos girarem. Essas figuras autistas desaparecem aos sete anos, sendo substituídas por atividades lúdicas, conversações e desenhos, porém ressurgem dois anos mais tarde, quando o tema dos desastres naturais passa a chamar a sua atenção. Para cada desastre, estereotipias motoras já abandonadas são retomadas, como o tornado, que reativa o antigo movimento giratório. Com o tratamento, esses gestos são integrados em sequências de jogo e incorporam um outro valor do ponto de vista dos processos de simbolização, transformando-se em tiques, que poderíamos chamar de "excentricidades". As repetições ocorrem em momentos de intensidade afetiva, quando L. experimenta uma forte alegria ou medo mas, diferentemente do quadro do início do tratamento, esses episódios são distribuídos descontinuadamente, podendo aparecer apenas em algumas sessões. Tornou-se possível ainda suscitar a sua interrupção, com uma nova resistência por parte da criança: o protesto e a reivindicação do seu "direito a girar”.

Em seu estudo sobre uma oficina de música, Lima (2012) apresenta uma intervenção similar, mas cuja orientação é musical, no atendimento de Heraldo. Trata-se de um menino que se mantinha alheio ao grupo, preferindo permanecer no pátio, sobretudo brincando com a torneira e observando as poças que se formavam quando esta permanecia aberta. Uma das formas encontradas para mantê-lo dentro do local da oficina foi oferecer-lhe alguns lápis ou gizes de cera, os quais ele manipulava e deixava ruidosamente cair no chão, esparramando-os no chão, assim como a poça d'água, voltando a repetir o processo ininterruptamente. As tentativas de tocar violão com ele ou cantar-lhe uma canção foram a princípio infrutíferas, mas o uso dos gizes configura o início de uma intervenção clínica a partir da sua inclusão em uma série que adquire um tempo e sentido:

Aproximo-me de Heraldo, pego alguns pedaços de giz e começo a bater uns nos outros, como pequenas clavas, e demonstro interesse por aquele som. Exploro as possibilidades, faço alguns sons com a boca e pequenas melodias. Heraldo acha graça e ri. Prossigo, agora fazendo um chocalho com os gizes entre as mãos, agitando-as num movimento ritmado enquanto cantarolo uma melodia. Heraldo começa ele próprio a emitir sons em alturas diferentes e começa a bater a palma da mão num banco, a toques secos. Começo agora a colocar algumas palavras na melodia, usando o nome de Heraldo, referindo-me às atividades que eles estavam fazendo àquela tarde. Heraldo sobe, então, nas minhas costas, apoiando-se. Os dois ficam balançando num pêndulo ritmado, enquanto o oficineiro canta: "Heraldo pra cá, Heraldo pra lá; Heraldo não sabe pra onde vai dá" (p. 71-72).

Os dois casos presentes na literatura confirmam os efeitos terapêuticos da narrativa que 
puderam ser verificados na oficina de música. Nos três contextos, a narrativa permitiu que afetos e representações fossem experimentados dentro da estrutura do jogo e da música, quando seria difícil vivê-los dentro da estrutura ordinária da linguagem. Mais do que isso, a inclusão de figuras autistas em séries narrativas demonstrou um impacto não só no modo como esses comportamentos são realizados e no sentido suscitado por eles, como também abriu uma possibilidade de entrada dos demais na construção dessas histórias, em uma interação colaborativa.

No que tange à experiência musical, a narrativa elaborada a partir de eventos musicais também pode ser empregada como forma de reconstrução do sentido. Como enfatiza Barcellos (2009),

poder-se-ia ver o paciente $[\ldots]$ como tendo a possibilidade de ser o narrador/ performer musical de sua[s] história[s] [...] o paciente tanto pode utilizar-se de músicas já compostas para realizar a sua narrativa, como improvisar ou compor. Além de cantar a história, pode exprimir verbalmente, se quiser e/ou puder, as suas reflexões e comentários sobre o expressado (p. 84-85).

Fazer música é análogo ao processo de constituição subjetiva: atribuir e perceber formas a qualidades emocionais, em um processo de crescente complexidade dimensional, ou seja, acrescenta-se uma sequência a ações que apenas tinham uma duração isolada, conectando-as em um sentido que é o da narrativa. No caso estudado por Rodulfo, girar deixa de ser apenas o movimento de rotação que o corpo físico faz ao manter um equilíbrio instável em seu eixo longitudinal. Torna-se agora um "tornado" que, ainda que obedeça metaforicamente às mesmas condições dinâmicas e conserve sua forma, tempo e intensidade - obviamente em uma escala menor -, proporciona um novo prazer. Se o movimento de girar provoca sensações auto-erógenas e intrassubjetivas, o tornado pode ser incluído em uma narrativa onde ganha um sentido, um tempo, uma história, que pode ser compartilhada e elaborada com um outro. $\mathrm{O}$ mesmo vale para o balanço de Heraldo e a corrida e a figura rítmica de William. "O afeto", como defi ne Green (2008), "é um movimento em busca de uma forma" (p. 23), e através das intervenções, o sentido produzido pela narrativa parece oferecer uma forma criativa a um conteúdo afetivo que antes só encontrava caminho para atualizar-se na repetição incessante. Tal modo de intervenção pode ser útil para compreender os efeitos que a música, enquanto forma artística, pode exercer em uma relação terapêutica, na medida em que o propósito da arte é capturar força com forma: "a força da experiência humana individual e a forma da experiência social coletiva” (BLACKING, 1985, p. 52).

Com efeito, os resultados da narrativa, como acompanhamos nesses casos, não operam 
apenas em um eixo sensorial individual, mas na articulação dos motivos do sujeito ao outro e ao Outro. Por meio da emoção compartilhada, que está no cerne da sua capacidade de conectar diversas mentes em um tempo e um espaço imaginário e poético, a narrativa estabelece um encontro no qual as identidades de si e dos outros podem ser reconstruídas e ressignificadas. Por meio das narrações, essas crianças experimentam o que é ser uma locomotiva, um tornado ou um caçador de jacarés. $\mathrm{E}$ as convenções culturalmente em voga colocam à disposição não só os modelos ideais para que essas operações se realizem, mas também os elementos estruturais para que elas elaborem as suas próprias histórias de vida. Essa relação, que une sujeito, alteridade e cultura, exprime-se desde as primeiras interações humanas, nas quais já é possível identificar os motivos do Outro. Não obstante, ela parece estar preservada em casos de autismo, apesar das dificuldades enfrentadas por esses sujeitos na elaboração de histórias sobre si mesmos. As formas narrativas enlaçam, desse modo, as dimensões intrapsíquicas, intersubjetivas e socioculturais, e determinam a sua função de pertencimento à cultura e a transição a um nível mais amplo da alteridade. E se o enquadramento temporal de acontecimentos em sequências narrativas emocionalmente compartilhadas é o fundamento da experiência cultural, certamente é também uma das razões de seus efeitos terapêuticos.

\subsection{Ritmo}

O ritmo constituiu um dos elementos essenciais no trabalho clínico com a música e as canções na oficina de música. Ele aparece no escopo das intervenções realizadas como uma das principais modalidades de intervenção nos aspectos corporais e intersubjetivos, em situações variadas. Um ritmo era necessário para tocar os instrumentos e acompanhar as canções, participar dos jogos musicais e também das danças e coreografias que encenamos. Em diversos momentos, as crianças não podiam fazer frente a essas exigências, porém em outros demonstraram uma capacidade especial de interagir com o outro de uma maneira sincronizada e coordenada no tempo, produzindo uma série de inquietações a respeito dessa dimensão do tratamento. Para abordar essa questão, primeiramente apresentaremos uma discussão sobre os aspectos estruturais do ritmo e sua relação com a comunicação e a música. Em seguida, acompanharemos sua relevância nos processos terapêuticos suscitados pela música. Paralelamente, serão 
apresentados comentários e reflexões sobre cenas ocorridas na oficina que tiveram o ritmo como um de seus elementos principais.

$\mathrm{Na}$ literatura, frequentemente encontra-se a preocupação de que a questão do ritmo, para ser devidamente compreendida, não esteja limitada aos sons, mas incluída em um escopo mais amplo e extramusical. Para alguns autores, como Dewey (2012), o ritmo resulta primeiramente da interação da criatura viva com seu meio, consistindo na alternância entre a perda da integração com o mundo e a recuperação dessa união. Com o desenvolvimento, o organismo aumenta sua complexidade e o ritmo de sua relação com o mundo se torna mais variado, incluindo diversos sub-ritmos que ampliam e enriquecem os projetos de vida, enchendo suas realizações de nuances e sutilezas.

Há pulsações rítmicas de desejo e realização, pulsos do fazer e do ser impedido de fa-
zer. [...] Todas as interações que afetam a estabilidade e a ordem no fluxo turbilho-
nante da mudança são ritmos. Existem o influxo e o refluxo, a sístole e a diástole: a
mudança ordeira. Esta se move dentro de limites. Ultrapassar os limites estabelecidos
equivale à destruição e à morte, a partir das quais, entretanto, se constroem novos rit-
mos. A intercepção proporcional das mudanças estabelece uma ordem de padrão es-
pacial, e não apenas temporal: como as ondas do mar, as ondulações da areia onde as
ondas fluíram e refluíram ou as nuvens lanosas e as de fundo escuro. O contraste en-
tre a falta e a plenitude, a luta e a realização ou o ajuste depois da irregularidade con-
sumada constituem o drama em que ação, sentimento e significado são uma coisa só.
Daí resultam o equilíbrio e o contrabalanceamento. Estes não são estáticos nem me-
cânicos. Expressam uma força que é intensa, por ser medida pela superação da resis-
tência. Os objetos circundantes beneficiam ou prejudicam (p. 79).

Jourdain (1997) também sustenta essa perspectiva, enfatizando que geramos ao longo do dia uma espécie de ritmo de movimento orgânico, composto não só pela pulsação cardíaca, mas por todas as atividades do corpo, como respirar, caminhar e correr, em sequências que compõem uma espécie de fraseado. Tal compreensão do ritmo é evidentemente anterior a uma consciência que pudesse apreendê-lo, mas indica também a possível incidência desses movimentos ao longo do tempo sobre a subjetividade, a qual, em sua perturbação e conflito, já "traz em si os germes de uma consumação semelhante ao estético” (DEWEY, 2012, p. 77). Se a música é possível, da forma que a conhecemos, é porque, assim como qualquer criatura viva, temos uma experiência rítmica do mundo.

Outro argumento comum nessa mesma linha é a invocação dos ritmos corporais, tais como as batidas do coração e o balanço da marcha, como fundamento do ritmo musical, sugerindo que a produção de sons e gestos os reproduziria de maneira análoga. Porém, de acordo com Delalande (2003), esse é apenas um dos preconceitos que impedem a compreensão correta da experiência do ritmo, dado que esses discursos geralmente se referem ao nível mais trivial da música. Além disso, essa proposição desconsidera que qualquer sincronização motora de- 
pende também de uma operação cognitiva, a saber, o processamento e reconhecimento de padrões de repetição ao longo do tempo. Outra crítica a esse argumento é a enorme multiplicidade de padrões fisiológicos e motores, a maioria deles ocorrendo fora da consciência, de modo que o enraizamento do ritmo no corpo provavelmente ocorreria uma maneira muito mais ampla e generalizada (JOURDAIN, 1997).

Outro mal-entendido frequente, segundo Delalande (2003), é a ideia de que o ritmo é uma característica universal da música. De fato, existe uma tendência a acreditar que, entre a diversidade de instrumentos e escalas, o ritmo seria um elemento que unificaria todas as tradições musicais existentes. No entanto, se definimos ritmo como a marcação de pulsações periódicas e durações com acentos fortes e fracos, vemos que o que se entende por esse termo em cada uma dessas culturas é algo absolutamente diferente. Nesse sentido, tal universalização consistiria apenas na projeção de um modelo sobre os demais, sendo mais aceitável uma concepção ampla de ritmo: a divisão das durações e acentos com o objetivo de formar figuras.

Se adotarmos uma perspectiva neurológica, o ritmo em que vibram as frequências seria o menor elemento discreto que determina o fenômeno musical. Segundo Thaut (2005), o fato de a música se desdobrar apenas no tempo indica que a base física da música está fundada nos padrões temporais de vibrações traduzidas em nosso aparatos auditivo em informação eletroquímica, que passa através dos mecanismos neurais do sistema auditivo e chega enfim ao cérebro, onde é integrada a informações provenientes dos demais sistemas e da memória para ser finalmente organizada em padrões. Não se trata, portanto, de um aspecto exclusivo da música, mas de um funcionamento cerebral mais amplo, relacionado aos padrões de distribuição temporal de eventos, objetos ou sinais em geral (BERLYNE, 1971). No nível neurológico, portanto, o ritmo se refere especificamente a divisões no tempo em sistemas temporais intervalares, recorrentes e geralmente caracterizados por periodicidade, como os pulsos, as batidas, a acentuação métrica, etc. Nesse sentido, toda ação humana possuiria um ritmicidade, na medida em que existe uma estrutura de grupos de divisões e similaridades que obedecem a regras de organização intrínsecas.

Para Trevarthen (1999), a organização de intervalos de tempo é fundamental para a coordenação de movimentos corporais de diferentes amplitudes e intensidades, e a integração das experiências perceptivas com os propósitos desses gestos. Isso ocorre com relação à percepção consciente de um presente psicológico, mas também é válido para intervalos menores, que permanecem inconscientes. Esse processo demandaria a existência de um mecanismo neural 
formador de motivos e composto por osciladores temporais, chamado por ele de Pulso Intrínseco de Motivos (Intrinsec Motive Pulse). Nessa perspectiva, as ações humanas não seriam apenas uma sequência de segmentos temporais. Todo o corpo vibraria em uma mesma frequência, que organiza o pensamento, a emoção e o movimento. Esses ritmos se encadeariam com os dos demais quando compartilhamos um pulso organizado com os outros, e essa relação estaria por trás da possibilidade de coordenarmos nossos corpos e emoções com um outro ser humano. De fato, entre os primatas e outros mamíferos, os seres humanos são a única espécie capaz de manter o tempo e de ajustar-se ritmicamente a um pulso externo (BROWN, 2000). Segundo Merker (2000), tal habilidade teria se originado nos coros de hominídeos primitivos, consistindo na raiz biológica da musicalidade humana, e poderia ser acompanhada, como observa Brito (2007), já nas produções musicais infantis.

\begin{abstract}
Observando o comportamento de crianças pequenas (com idades entre dois e três anos) quando interagem com uma canção (que escutam e acompanham), percebemos que elas realizam, muitas vezes, movimentos regulares: palmas, gestos corporais, toques num instrumento, etc. Intuitivamente algumas crianças apreendem o pulso, sem que isso seja um critério ordenador, de maneira que a mesma canção pode passar a ser acompanhada [não-metricamente]. Manter o pulso, dessa feita não constitui um valor para elas e é algo vivenciado em sua organicidade, sem a consciência intelectual que reconhece e valoriza este aspecto como fundamental à correta realização musical (ao menos em grande parte das produções musicais) (p. 83).
\end{abstract}

Para avançar na compreensão da questão do ritmo dentro de nossa prática, buscaremos a partir de agora enquadrá-la na perspectiva do desenvolvimento infantil, de modo a explicitar como se desenrola a ritmicidade da experiência ao longo do ciclo vital. Para Bruscia (1999), durante a etapa em que está protegido pelo líquido amniótico, o feto percebe os movimentos e sons do corpo da mãe de maneira amortecida e difusa. É apenas quando a bolsa se rompe e seu corpo entra em contato com as paredes do canal de nascimento que os sons e as vibrações são percebidos diretamente, junto com as contrações periódicas que alternam estados de pressão e liberação. Após o nascimento, conforme os movimentos espontâneos e globais se diferem progressivamente da conduta reflexiva, as formas iniciais do funcionamento psíquico seriam justamente as estruturas de ritmos (PIAGET; INHELDER, 2003). Mesmo os reflexos, como a sucção, dependeriam da estrutura rítmica, dado que conduzem de um estado inicial a um estado final, recomeçando nessa mesma ordem, e já seriam esboços das primeiras regulações e reversibilidades.

Apesar de serem processos constantes no desenvolvimento humano, os ritmos não se configuram de maneira uniforme entre todos indivíduos. Nos estudos de Boysson-Bardies (1991) com a chupeta eletrônica, por exemplo, verificou-se que cada bebê possuía um ritmo de 
sucção pessoal, definido pela amplitude dos movimentos. Poderíamos encontrar aí a primeira expressão de uma identidade rítmica (ALLIONE, 2007), que acompanhará o sujeito ao longo da vida. Certamente, mesmo sendo uma característica quase instintiva, o ritmo se encontra desde os primeiros momentos no contexto das interações com o mundo, estando assim sujeito à ação das forças pulsionais e aos encontros com o outro, acompanhando a gênese da ideia de tempo. De fato, como ressalta Goux (1999),

A pulsão é essencialmente dinâmica, motora, [...] é uma capacidade para acionar a motricidade, uma pressão definida como o fato de ir em direção a, de tender a, e que, como um processo dinâmico marcado pela escansão rítmica de uma tensão e um relaxamento, engaja uma concepção genética do tempo, uma concepção da criação do tempo (p. 78).

Quando analisadas em um nível micro, as interações entre bebês e seus cuidadores apresentam um nível de organização temporal bastante complexo, facilmente identificável nas trocas vocais entre ambos (MALLOCH, 1999; TREVARTHEN, 1999). À medida que o bebê se torna capaz de produzir e responder aos sons do seu par, por volta dos 2 ou 3 meses, observa-se que as vocalizações dos adultos são periódicas, por um curto período de tempo, por exemplo quando o nome, uma palavra ou um som é repetido várias vezes enquanto as alturas e intensidades são ligeiramente moduladas. Essa ritmicidade é geralmente implícita e ressurge diversas vezes durante a interação (GRATIER, 2007), sendo chamada por esses autores de pulso. Foi justamente esse aspecto da comunicação entre bebês e seus cuidadores que deu origem ao conceito de musicalidade comunicativa, a partir da análise de Malloch das gravações feitas por Trevarthen (1979) das interações entre Laura, de apenas seis semanas, e sua mãe. Apesar de, na época, este último ter identificado que a mãe se aproximava da filha por meio de sons imitativos, que eram modulados emocionalmente para provocar um intercâmbio expressivo em um tempo compartilhado, algo mais chamou a atenção do ouvido musicalmente treinado do primeiro.

Conforme eu escutava, intrigado com o fluido leva e traz da comunicação e o discur-
so cadenciado da mãe enquanto ela conversava com seu bebê, comecei a bater meu
pé. Sou músico por formação, então estava muito acostumado a sentir automatica-
mente a batida enquanto escutava sons musicais [...]. Eu substitui a fita e, de novo,
podia sentir uma ritmicidade distinta e um leva e traz melodioso nas provocações
gentis da mãe de Laura e as respostas vocais afinadas de Laura [...]. Algumas sema-
nas mais tarde, enquanto descia as escadas para o laboratório principal de Colwyn, as
palavras "musicalidade comunicativa" vieram a minha mente como uma maneira de
descrever o que eu tinha escutado (TREVARTHEN; MALLOCH, 1999, p. 3-4).

Segundo Gratier (2007), os ciclos de apresentação daquilo que forma o familiar, o recorrente, o periódico, constituem um envelope rítmico para o bebê, similar ao envelope sonoro 
de Anzieu (1995). As repetições e variações da experiência forneceriam os primeiros indícios do tempo, já que o reconhecimento, o retorno e a certeza do que foi experimentado antes toma forma no horizonte do futuro. Nesses ritmos da intersubjetividade, o sentido se estabelece entre o retorno do mesmo e as aparições da diferença, conduzindo os contatos emocionais no quadro dos contornos de vitalidade e enriquecendo-os com o suspense e a expectativa. Nessa precoce apreciação estética do tempo, bebês e cuidadores são verdadeiros artistas, e a interação entre eles uma escultura temporal (GRATIER, 2007), nas quais são possíveis a antecipação e a participação com um pulso isocrônico.

Assim como vimos antes, sob uma perspectiva neurológica, as vocalizações, gestos e movimentos nessas interações demonstram que o ritmo representa uma forma de coordenação interpessoal do tempo (coordinated interpersonal timing) (BEEBE et al., 2000, JAFFE et al., 2001). Essas evidências sugerem que a experiência individual do fluxo temporal, na verdade, está construída sobre interações com outros. Aqui novamente encontramos uma indicação para compreender os efeitos terapêuticos da música, à medida em que facilitaria a construção de um tempo compartilhado. Isso fica evidente no trabalho com Mathias pois, partindo da percepção de sua dificuldade em acompanhar os movimentos dos demais de maneira sincronizada, as intervenções puderam auxiliá-lo na regulação do ritmo, o que possivelmente tem um impacto em suas relações sociais. Pois, quando o tempo é coordenado ao fazer música juntos, defende Schutz (1976), produz-se uma quase-simultaneidade entre o fluxo subjetivo de consciência e a estrutura dinâmica do objeto temporal, de modo que a fronteira entre sujeito e objeto se afasta e dá lugar a uma experiência do "agora”. Como enfatiza Williams (1965), não se trata de uma metáfora, mas de uma experiência real.

O ritmo é um meio de transmitir uma descrição da experiência, de tal modo que a experiência é recriada na pessoa que o recebe, não meramente como uma "abstração" ou uma "emoção", mas como um efeito físico sobre o organismo - no sangue, na respiração, sobre os padrões físicos do cérebro (p. 41).

Se, por um lado, esse é justamente o sentido de estarmos afinados, como preconiza Schutz (1976), isto é, de viver juntos ao longo do mesmo fluxo, envelhecer juntos enquanto dura o processo musical, podemos deduzir, por outro, que esse é um dos aspectos principais responsáveis pelos efeitos terapêuticos da música.

Novamente, a incidência do ritmo na saúde não corresponde a uma metáfora, mas sim a processos concretos do funcionamento psíquico. Como argumenta Jourdain (1997), a música afeta os sintomas ao promover no cérebro um fluxo de informações e um nível de organização acima do normal, ao mesmo tempo em que estimula e coordena as atividades cerebrais. De 
fato, como defende Padilha (2008), a música é capaz de regular o comportamento sensitivo e motor, podendo o ritmo reduzir comportamentos estereotipados. Isso pode ser de peculiar importância para as finalidades do tratamento, na medida em que, conforme autores como Chavarrias (2002), o sujeito com autismo seria "arrítmico por natureza" (p. 151). Oferecer-lhes um ritmo, por si só, já seria então terapêutico, pois compensaria as falhas no desenvolvimento que conduziram a essa condição. Igualmente, tal arritmia indicaria as dificuldades intersubjetivas que essas crianças enfrentam, ressaltando os benefícios que a música pode trazer ao oferecer um ritmo estruturado, que sirva de apoio à apreensão da sua própria realidade, bem como da realidade exterior.

Uma das características das sessões da oficina de música é que na maior parte das atividades havia uma marcação definida do pulso, seja das canções ou dos jogos musicais. Essa situação se diferencia de uma orientação do dispositivo em função da improvisação, quando as interações musicais são mais frequentemente caracterizadas por métricas livres ou pulsos instáveis. Um dos resultados, como pudemos verificar, é que as crianças acompanham as canções marcando o seu pulso, não importa o instrumento que estivessem tocando (Fig. 7, 8, 10). Possivelmente, esse comportamento facilitaria o seu engajamento nas atividades, e lhes permitiria compartilhar um momento com os demais com uma qualidade que não seria possível de outra forma.

Isso pode ser válido até mesmo para casos severos da enfermidade. Por exemplo, ampliando a noção de ritmo para um escopo mais amplo e extramusical, podemos acompanhar seus efeitos em um caso de autismo, apresentado por Allione (2007). Como ela refere, tratava-se de uma menina com um grave prejuízo social e da linguagem, que costumava permanecer imóvel por longos períodos. Como que imitando uma estátua, ela um dia desapareceu atrás das cortinas da janela, o que foi interpretado pela autora como uma maneira de desaparecer do campo do Outro, mas também como uma mensagem: estou aqui para que alguém me descubra. Surgiu ali a oportunidade de reproduzir o jogo tão frequente entre crianças pequenas, de aparecer e desaparecer repetidamente, o que permitiu um dos primeiros contatos no contexto da terapia e estabeleceu o caminho por onde seria possível avançar.

Nesse sentido, o ritmo favoreceu também a coesão do grupo, tendo um aparente impacto na manutenção da disposição em roda. Para crianças que não podiam sustentar esse formato de estar com o outro, como William e Camila, as músicas ritmadas favoreceram seu contato, atraindo o primeiro para a roda (p. 52), e estabelecendo uma interação indireta da segun- 
da com os demais, na medida em que chacoalhava um instrumento no mesmo pulso em que tocávamos, mesmo estando distante (p. 72). Isso contribuiu para que o grupo rapidamente adquirisse uma familiaridade entre si, facilitando o processo terapêutico.

Outro fator de relevância do ritmo para a clínica é que ele cria antecipação e predizibilidade, e nesse sentido ele é um dos aspectos que criam o senso de narratividade. Ao ser compartilhado, o ritmo produz um pulso fundamental que orienta as interações, tornando as ações futuras previsíveis. Ele estabelece assim uma estrutura de organização temporal que pode ser benéfica para que indivíduos com autismo se engajem com os outros em uma sequência controlada de acontecimentos, que não afete a sua necessidade de regularidade e preservação da igualdade. Como mostra Schutz (1976), ao tocar juntos, cada músico

deve levar em consideração o que o outro deve tocar em simultaneidade. Ele não
apenas deve interpretar a sua parte, a qual permanece necessariamente fragmentada,
mas também deve antecipar a interpretação do outro músico da sua - do Outro -
parte e, mais ainda, as antecipações do Outro da sua execução. A liberdade de cada
um de interpretar o pensamento do compositor está restringida pela liberdade dada
ao Outro. [...] Ambos compartilham não apenas a mesma durée interna na qual o
conteúdo da música executada se atualiza; cada um, simultaneamente, compartilha
em um presente vívido o fluxo de consciência do Outro em instantaneidade. Mesmo
se executadas sem intenção comunicativa, essas atividades são interpretadas por ele
como indicações do que o Outro vai fazer e, portanto, como sugestões e mesmo co-
mandos para seu próprio comportamento (p. 176).

Essa sincronização compartilhada do tempo interno de cada um é facilitada pela proximidade e o contato visual. Porém, quando essa mediação direta é perdida, torna-se necessário algum elemento comum que, por meio de uma ação no mundo exterior, traduza os eventos musicais que ocorrem no tempo interno de cada músico em gestos expressivos à disposição de todos. Essa função geralmente é desempenhada pelo regente da orquestra, que transpõe pantomimeticamente um pulso organizado a todos os instrumentistas, que, por sua vez, não necessitam olhar entre si, já que por meio desse artifício compartilham um mesmo tempo. $\mathrm{Na}$ oficina, o violão foi o instrumento que geralmente organizava o ritmo, já que o acompanhamento das canções era feito de uma maneira estável, com pulsos definidos e estruturas harmônicas simples. Isso não impedia que canções com uma estrutura rítmica mais complexa, como "O pato pateta”, estruturado em uma alternância de compassos binários e ternários, fossem incluídas no repertório e gozassem de uma preferência pelas crianças. Mas, se comparado com as demais, tratava-se de um caso isolado.

Por outro lado, essa foi uma das canções que permitiu uma série de intervenções baseadas em outro fenômeno que teve saliência nas sessões e que está relacionado ao ritmo: as codas. Como demonstrado em nossas descrições, elas indicam o prazer e o interesse das crianças 
em brincar com a antecipação e a expectativa. Talvez esse momento de suspense fosse aquele no qual elas mais se arriscavam, variando o tempo da espera e o conteúdo que encerrava a história, denotando também uma grande segurança. Como ressaltado por Barcellos (2009), as letras das canções acentuam a sua familiaridade, previsibilidade e confortabilidade que, associados à base rítmica dos instrumentos, terminam por constituir uma espécie de "continente sonoro/musical" (p. 50), o qual constituiria essa base segura.

O ritmo, por fim, pode ser pensando também na intersecção entre a voz e a fala, já que tanto é um elemento da musicalidade da palavra cantada quanto um organizador do discurso da palavra falada. Se dizemos, por exemplo, que a posição de uma vírgula altera um enunciado, é porque o sentido do discurso depende do significado das palavras, mas também da disposição de suas pausas e escansões. Essa dupla pertinência do ritmo, segundo Bernstein (1976), pode ser a base de uma comparação entre a música e a linguagem: assim como o significado de uma frase falada não resulta apenas das palavras, mas de como elas estão ordenadas, o sentido de uma peça musical não deve ser encontrado nas notas e durações individuais, mas nas frases musicais que transmitem informações expressivas sobre o modo como as notas estão conectadas. Na fala e na música, é a percepção de um ritmo que amalgama os componentes discretos, e permite entender que os mesmos estão ligados em um nível maior de organização.

Essa dimensão rítmica como fundamento da linguagem foi enfatizada por Freud (1920/1996), na observação de seu neto de um ano e meio. Brincando com um carretel, o menino atirava o objeto para fora de sua vista, proferindo simultaneamente um longo "O-O-O-O", para depois puxá-lo de volta, dizendo “da”, repetindo a jogada novamente. No acompanhamento cantado da brincadeira, Freud encontra uma incipiente construção da linguagem, entendendo que a vogal "o" já continha em si o gérmen da palavra "fort" ("foi embora"). Como sugere Allione (2007), o fort-da introduz a criança na linguagem por meio do som e da repetição, já que é rítmico e ritmante. Será esse o sentido da expressão “só se”, que Mathias escreve de maneira reiterada na carta que me entrega (Fig. 29)? De qualquer modo, trata-se de uma ideia complementar àquela apresentada logo antes, pensada em termos psicanalíticos por Goux (1999): "O que une, entre corpo e linguagem, voz e texto, é a tensão pulsional do ritmo, sua cadência de impulsos e repousos” (p. 91). Do mesmo modo que a pulsão une o psíquico e o somático, o ritmo une o texto e a voz. Ele é, portanto, a energia da pulsão invocante.

O ritmo pode, como acompanhamos nesta seção, ser considerado a partir de uma série de perspectivas, tanto musicais quanto extramusicais. Ainda que seja referido à maneira como 
reconhecemos figuras e padrões nas repetições e variações do som ao longo do tempo, podemos apreendê-lo até mesmo nos processos vitais que moldam a relação do organismo com seu meio. Já quando enquadrado no desenvolvimento infantil, vemos que uma ritmicidade incipiente emerge desde as primeiras interações que o bebê estabelece com seus cuidadores, quando o sentido de tempo é criado por meio do compartilhamento de um pulso e das experiências de antecipação e expectativa. Esses aspectos são fundamentais para entender o modo como são produzidos os efeitos terapêuticos da música. Contudo, para além das dinâmicas sonoras coletivas decorrentes das canções, os aspectos rítmicos do trabalho terapêutico podem ser encontrados também em outras atividades e intervenções da oficina. Uma das formas interativas em que isso ficou mais evidente foram nas danças e coreografias que realizamos, como discutiremos a seguir.

\subsection{Corpo}

Para discutir os aspectos do movimento corporal na oficina de música, é importante considerar duas dimensões da clínica com crianças com autismo, a saber, a motricidade e o ritmo corporal. Como mencionado anteriormente, a música apresenta uma forte relação com o movimento e a ação corporal, de modo que os gestos que a acompanham podem estar fora do limite da consciência, como se estivessem concretamente ligados à própria música, e não só ao indivíduo que os realiza. Esse vínculo pode ser observado em danças tradicionais, como o juju da Nigéria (WATERMAN, 1991) ou as performances das cortes reais do Cambodja (SAM; CAMPBELL, 1992), onde a coreografia não é considerada um ornamento ou extensão da música. Da mesma forma, como ressalta Campbell (1998), essa mútua presença é observada nos movimentos que as crianças podem fazer na presença da música: "balançar, saracotear, agitar a cabeça, abanar os braços ou arrastar os pés, ou emitir qualquer um de uma variedade de comportamentos rítmicos em seus corpos conforme cantam ou brincam, e podem ser levadas a mover-se pela música ao vivo e mediada que as rodeia” (p. 189).

Segundo Fraisse, Oleron e Paillard (1953), esses são exemplos dos efeitos dinamogênicos da música no corpo, resultado da excitação fisiológica que se produz de uma sequência regular de eventos sonoros. Por maior que seja o esforço em escutar intelectualmente, de uma 
maneira supostamente desvinculada do corpo, existe uma tendência humana a marcar de uma forma motora o pulso das estruturas expressivas percebidas no tempo, já que os níveis de energia muscular oscilam de acordo com a frequência da fonte sonora, e o organismo responde de alguma forma, ainda que involuntariamente. Esse fenômeno não só explica porque crianças com uma coordenação muscular pobre podem ter dificuldades no estudo da música (WILLOUR, 1969), como fica evidente em métodos que têm no ato de sentir a música no próprio corpo o núcleo de sua proposta pedagógica (JAQUES-DALCROZE, 1945).

No entanto, não podemos reduzir a experiência musical no corpo a um simples reflexo motor condicionado a um estímulo sonoro. Como lembra Delalande (2003), existe necessariamente um componente cognitivo, já que a dança supõe uma operação mais complexa a partir da antecipação das pulsações seguintes para permitir a resposta sincronizada do gesto. Uma outra crítica apresentada por esse autor é a de que, apesar de concordar que o corpo seria o lu gar fundamental da experiência musical, a ideia de que o ritmo musical enquanto pura repetição regular seja responsável pela indução de movimento é infundada, fruto de uma concepção grosseira da noção de ritmo, já apresentada na seção anterior. No entanto, se acompanhamos a evolução da dança no desenvolvimento da criança, vemos que ela parte das experiências sensório-motoras e inclui as primeiras explorações de fontes sonoras e com os sons da boca. Trata-se de ações que ainda carecem de ritmo, são simplesmente gestos (DELALANDE, 2003). Porém, é justamente o gesto que permanece ao longo da vida como forma de desenhar o som, de criá-lo e controlá-lo. Mais que na repetição, é no gesto que a fisicalidade do corpo e da onda sonora se encontram: no golpear com as mãos, soprar com a boca, friccionar, esfregar ou atritar os materiais, etc.

De acordo com Delalande (2003), ao longo do primeiro ano de vida, conforme se desenvolve a tonicidade muscular e o bebê começa a controlar de maneira mais e mais precisa os movimentos do corpo, a música estimula o balançar, ainda que a sincronização entre os dois apareça apenas por volta dos quatro anos. Para esse autor, a sensação que a criança tem ao ser embalada provoca prazer porque, possivelmente, reproduz o balanço experimentado enquanto flutuava no líquido amniótico do útero em função do caminhar da mãe. Outra hipótese seria que o balanço excita os canais semicirculares do aparelho vestibular, fazendo agitar suavemente os líquidos que preenchem esses tubos ósseos, envolvidos tanto na audição quanto na manutenção do equilíbrio. O fato é que balançar o bebê segue sendo uma das técnicas mais usadas para acalmá-los, e esse será um gesto que a criança buscará repetir de distintas formas, nos 
brinquedos infantis como balanço, gira gira, trepa trepa e gangorra, assim como na dança. Por outro lado, problemas no desenvolvimento podem levar a um atraso ou redução do comportamento de balançar-se, ou a sua persistência na forma de uma estereotipia com a função de auto-estimulação, como é frequente no caso do autismo.

Outros problemas com essa população são os comprometimentos na postura e na conduta motora. Alguns estudos indicam que a criança com autismo pode aprender a rolar, engatinhar e andar, mas esses movimentos podem ser pobres em qualidade (WING, 1996). Na medida em que ela cresce, essas diferenças no desenvolvimento motor implicam em problemas no equilíbrio e nas reações de endireitamento (mover o corpo para manter a posição vertical), reações de proteção (utilizar a mão para apoiar-se ao cair) ou nas estratégias de movimento (coordenação dos membros, controle da respiração e da flexibilidade) (VILENSKY; DAMASIO; MAURER, 1981). Podemos pensar que a postura de sentar-se com as pernas dobradas para trás em W, apresentada por Mathias, seria um indício dessa condição, já que se trata de um modo de equilíbrio útil nas fases iniciais do desenvolvimento, mas que depois deveria ser substituído por outras formas, como as pernas cruzadas adiante. Da mesma forma, chama a atenção como no final da coreografia de Cocoricó (Fig. 27), enquanto todos terminam com os joelhos flexionados, Mathias estica as pernas, cruzando os braços sobre o peito. De acordo com Smith (2000), existe uma controvérsia se a posição em W seria deletéria ou atrasaria a remodelação natural da anteversão femoral, já que alguns pacientes com essa condição ortopédica costumam persistir nessa postura, na medida em que ela compensaria uma torção tibial externa e resultaria em um ângulo de pé normal. Infelizmente não temos informações sobre Mathias que permitam contribuir a essa discussão.

Os aspectos rítmicos do movimento corporal também são afetados no autismo conforme indicam os resultados de uma análise comparativa feita por CONDON (1975) de filmes de 25 crianças, com autismo ou com problemas menores de leitura. Após apresentar um estímulo sonoro, esse pesquisador notou que os sujeitos do primeiro grupo pareciam responder ao som não apenas quando ele realmente ocorria, mas uma segunda vez, após um intervalo que variava entre uma fração de segundo e um segundo. Em uma tentativa de replicar esse experimento, Oxman, Webster e Konstantareas (1978) não encontraram evidências do fenômeno das múltiplas respostas. No entanto, apesar de não validar a hipótese, eles confirmaram a noção de uma organização de resposta dessincronizada ou desajeitada (dyssynchronous, or awkward, response organization) de crianças autistas, se comparada com os movimentos corporais suaves 
e encadeados daquelas com desenvolvimento típico.

Da mesma forma, ao analisar vídeos de gêmeas de 11 meses, uma das quais se tornou autista no segundo ano, Trevarthen e Daniel (2005), encontraram evidências de que as mudanças em sua atenção, tônus muscular, iniciativa e emoções reduziram seu controle prospectivo de movimentos e suas antecipações, se comparada com a irmã. Nas brincadeiras, ela apresentava um comportamento social assincrônico (asynchronous social behaviour) em relação ao pai, o que frustrou seus esforços em ajudá-la a andar, compartilhar brinquedos ou brincar, e confundiu suas antecipações, resultando em uma atenção mútua e atividade conjunta reduzidas. $\mathrm{Na}$ análise do vídeo de uma "brincadeira de monstro", em que o pai se aproxima fazendo ruídos até atacar a barriga das meninas, a gêmea que não desenvolveu o autismo se engaja na brincadeira em sincronia e com uma reciprocidade cíclica de expressões, resultando em um evento social e intersubjetivo produzido por intenções compartilhadas. Para a outra irmã, a sequência não é realmente uma interação de reciprocidade mútua, ou seja, não é uma verdadeira brincadeira.

Intervenções orientadas à desorganização rítmica de algumas crianças produziram mudanças significativas no modo como elas interagiam com as demais nas coreografias. $\mathrm{O}$ caso de Mathias é emblemático, sobretudo com relação aos intervalos entre a execução de seus gestos e os dos demais, como pudemos verificar nos passos de uma ciranda (Fig. 25). O atraso nos movimentos é algo que caracteriza as performances de Mathias, em contraste, por exemplo, com a maneira sincronizada com que Pablo realiza os movimentos da canção "A dona aranha”, junto com Beatriz (Fig. 15).

A dificuldade de Mathias em acompanhar o ritmo do outro fica evidente quando analisamos a coreografia da canção "Cocoricó" (Fig. 27). Podemos perceber que a condução dos passos é feita exclusivamente por Pablo, que põe os membros de Mathias em movimento. Assim como na brincadeira da gêmea com autismo analisada por Trevarthen e Daniel (2005), em que a ausência de reforçamentos sociais e regulados afeta o estilo de interação do pai, que a estimula repetidamente na tentativa de envolvê-la, os esforços de Pablo produzem apenas gestos truncados e desajeitados, em contraste com a sincronia com a qual dançam Sofia e Thales. Em última instância, não se trata de uma dança como uma ação intersubjetiva compartilhada. $\mathrm{E}$ talvez seja esse o motivo que faz Pablo abandonar o seu par e juntar-se à outra dupla.

De qualquer modo, um avanço pôde ser identificado nesse sentido. Se compararmos essa situação com a tentativa de reproduzir a coreografia de Sofia (Fig. 24, 25), vemos que a di- 
ficuldade em imitar os gestos simetricamente e em sincronizar os movimentos são obstáculos para estabelecer um verdadeiro engajamento nos gestos do outro, e que muitas vezes Mathias apenas observa os passos dos demais. Certamente, a proposta de Sofia era bastante mais complicada que a minha de dançar livremente ao som da música, o que constituiu um fator de complexidade adicional. No entanto, podemos entender o desenvolvimento da expressão gestual de Mathias nesse segundo momento dentro do quadro da melhora qualitativa de suas interações sociais.

Como consequência, a partir dos benefícios que a expressão corporal pode oferecer, intervenções podem ser estabelecidas em função dos objetivos do tratamento. A literatura indica que a dança pode ser usada como um recurso para reconfigurar a conduta corporal (DENORA, 2003), para desenvolver a atividade motora grossa rítmica, a locomoção, a psicomotricidade de movimentos livres e estruturados (PADILHA, 2008), mas também para aprimorar a atenção e memória, a capacidade de expressão, a capacidade rítmica e a orientação espaçotemporal (LEINIG, 2008).

Um outro aspecto que pode ser pensado nessa mesma linha da organização corporal foi o modo como os participantes tocavam seus instrumentos. Como acompanhamos nos estudos de caso, sempre houve uma ênfase na escolha dos instrumentos, e mesmo quando alguém não tinha - ou não queria ter - um deles em mãos, sugeríamos que fossem usados os pés, a voz ou qualquer outro objeto que estivesse próximo. Segundo Padilha (2008), tocar instrumentos é um comportamento tangível e estruturado que aumenta a atenção, incrementa a coordenação motora fina e grossa e a coordenação entre o olho e a mão, melhorando a percepção auditiva, visual e tátil. Igualmente, incide sobre as habilidades sociais, aumentando a participação e a coesão do grupo, além de auxiliar na expressão de emoções. Esse argumento é corroborado por Benenzon (1988), para quem a importância dos instrumentos musicais como objetos intermediários decorre da abertura de novos canais de comunicação, podendo transformar-se tanto em objetos de identificação como de projeção.

Por sua forma, o instrumento exige que adaptemos nossa postura e nossos gestos para poder extrair dele um som desejado. Um exemplo é quando William precisa modular a pressão de seu sopro na flauta para obter tanto sons fortes quanto fracos (Fig. 14). Por ser um objeto material, o instrumento também oferece resistência ao corpo que o toca, abrindo todo um outro campo de intervenções terapêuticas em torno à sensibilidade do tato, o uso de texturas e as distintas forças aplicadas. Uma das maneiras de fortalecer a voz e a expressão de Pablo, como 
vimos, era que ele tocasse com força o tambor, pronunciando as sílabas do instrumento a cada golpe (p. 69). Isso inevitavelmente fazia com que a sua voz também adquirisse essa característica, tornando-se muito mais audível, o que sugere que intervenções baseadas na sobreposição de uma ação sobre a outra podem ser efetivas, dada a possibilidade de apoio apresentada pela pulsão (FREUD, 1905/1976).

Nessa chave, podemos entender que os movimentos do corpo na música - sejam eles elementos de uma dança e coreografia, ou mesmo uma postura ou uma maneira de tocar diferentes - dizem respeito a uma forma específica de experimentá-lo. Mas, longe de ser uma experiência solitária, novamente encontramos aqui a incidência da alteridade, na medida em que o engajamento nos gestos do outro promove interações sociais baseadas na comunicação e coordenação de movimentos. Esse processo está presente não só na imitação que Pablo faz dos meus gestos com os braços representando a boca do jacaré (Fig. 20), mas também nas coreografias de roda, que, no entender de Leinig (2008), têm como principal objetivo a socialização. De fato, dar as mãos estabelece um contato mais próximo, de modo que as figuras de roda podem oferecer uma intervenção inclusiva mesmo a sujeitos que preferem manter-se à margem do grupo, como no caso de Camila (p. 74-75). Da mesma forma, elas podem também ser uma maneira de estimular o ajuste da velocidade, direção e intensidade dos movimentos próprios aos dos demais, como ocorreu com William naquela mesma sessão. Atividades baseadas na dança, portanto, podem oferecer um envelope corporal da experiência, o que possivelmente é benéfico a essas crianças

Assim, apesar da sugestão de que a dança seja considerada em conexão direta com a música, sem requerer um controle consciente por parte do sujeito, muitas vezes vemos que a expressão musical requer que o indivíduo ajuste os gestos do corpo às qualidades formais do som. Segundo DeNora (2003), essa exterioridade da música ocorre com todo tipo de material e objeto, e justamente por esse motivo ela é constitutiva do social, na medida em que elementos extramusicais tomam forma em relação à música. No caso dos movimentos corporais, isso ocorre quando nos movemos de maneiras orientadas aos ritmos da música, por exemplo, ao marchar junto de um ritmo binário.

Pode-se dizer que a música "proporciona" o movimento na medida em que é percebida como perfis de tipos específicos de movimento (por exemplo, andamentos, níveis de energia, estilos de movimento) e os mesmos são colocados em prática na medida em que os atores executam seus movimentos corporais em função das suas propriedades (p. 47).

O movimento rítmico das crianças pode, portanto, e em concordância com Campbell 
(1998), ser indicador do que elas estão escutando ou prestando atenção, ou mesmo no que estão pensando. Elas podem estar envolvidas em uma atividade, porém batendo os pés na pulsação de uma música que venha de fora, por exemplo. Todas essas são marcas da incidência que a música exerce sobre nós, e mostram que o corpo é o lugar privilegiado para essa apropriação. Mais que isso, elas são a prova de que a música é capaz de reestruturar as dimensões da nossa experiência corporal, e que a dança é um modo de comemorar essa possibilidade. Como afirma Didier-Weill (1997b),

o que põe o sujeito em movimento, na dança, sem que ele tenha, para isso, de fazer esforços, deve-se ao fato de que o deslocamento no qual ele se lança arranca-o de um lugar onde ele não pode mais ficar: ele não o pode mais porque, a partir do momento em que soa a música, o novo lugar onde ele se encontra situado cessa de estar limitado pela orientação espaço-temporal que recebia da lei simbólica, para adquirir subitamente a característica de um lugar habitado pela amplidão do ilimitado (p. 240).

E na experiência desse puro ilimitado, que não é acessível à captura, posse ou conhecimento, mas que se traduz na descoberta de um outro corpo, com novos gestos e encontros com o corpo do outro, está o núcleo das possibilidades que a música pode oferecer quando empregada com fins terapêuticos: "Dançando esse puro excesso que é o ilimitado, o sujeito descobre o que ele não é: cessa de ser limitado pela lei especular (torna-se invisível), cessa de ser limitado pela lei da gravidade (torna-se imaterial), cessa de ser limitado pelo interdito simbólico (torna-se inaudito)" (idem, p. 241), encontrando ali as condições para tornar-se outro.

Postura, gesto e ritmo corporal são, portanto, aspectos que orientam a condução das intervenções que buscam incidir em aspectos da expressão corporal dos participantes. Um outro elemento importante que também é trabalhado clinicamente durante as danças e coreografias, a imitação, aproxima-se desses aspectos, na medida em que se refere também à dinâmica de coordenação dos movimentos do corpo. Um aprofundamento nessa questão será realizado na próxima seção.

\subsection{Imitação}

O conceito de imitação é geralmente referido na teoria musical como a representação sonora de objetos em uma peça. Em nossa prática, por exemplo, essa acepção poderia ser iden- 
tificada nas diversas onomatopeias presentes nas sessões da oficina. Trata-se de um recurso que pode ser usado para tornar as improvisações emocionalmente envolventes e provocar um intenso engajamento entre os participantes, tal como ocorreu com a "Música assustadora" (Fig. 12), a "Música da ilha do Medonho" (p. 50-51) e o passeio com Camila (p. 73-74). No entanto, uma outra forma chamativa de imitação podia ser identificada em nossas atividades, quando um indivíduo se apropriava de um gesto de outra pessoa para torná-lo próprio, demonstrando uma conexão em um nível intersubjetivo.

A imitação intersubjetiva foi, portanto, um fenômeno frequentemente observado nas interações entre os participantes. Ela podia aparecer como uma imitação direta, no sentido que as crianças estavam evidentemente compartilhando uma experiência juntos, mas também em outros momentos em que isso não era tão claro. Ao acompanhar os registros audiovisuais, vemos que em algumas oportunidades, por exemplo, Mathias deixa de tocar o xilofone suavemente e com precisão e passa a golpeá-lo desajeitadamente com violência imediatamente após William golpear um brinquedo contra a mesa, o que produz um som forte. Apesar de este não estar no campo de visão do outro, e nem mesmo em sua proximidade física, o som produz entre eles algum tipo de contágio, e modula a forma com que o segundo toca o seu instrumento (p. 30).

Esse fenômeno de imitação indireta também me chamava a atenção nas atividades de improvisação que desenvolvia no Lugar de Vida. Em algumas situações, crianças que ocupavam distintos lugares da sala, tocando seus instrumentos de maneira alheia às demais, por alguns instantes compartilhavam um mesmo gesto, pulso ou intensidade, entrando em uma sincronia e harmonia pela via do som. Inconscientemente, a música invadia seus supostos isolamentos, fazendo-as negociar uma produção sonora compartilhada. Essa possibilidade de deixar-se afetar por meio do som torna ainda mais claro o papel que a música pode exercer na clínica dos distúrbios do desenvolvimento, fazendo a presença do outro possível mesmo ali onde ele não está e não poderia ser tolerado.

Seguramente, a imitação é um dos elementos fundamentais nas interações humanas. Com ela, é possível a comunicação por meio de formas expressivas baseadas no corpo, tanto voluntárias quanto involuntárias, em sincronia com as expressões faciais, vocalizações, posturas e movimentos de outra pessoa (GIBBS, 2010). De fato, a capacidade para imitar um outro pode ser encontrada desde o início das interações sociais, e está ligada aos primeiros exercícios de musicalidade comunicativa. Meltzoff e Moore (1977), por exemplo, encontraram imitações 
da protusão da língua em bebês de 12 a 21 dias, e mostraram que eles não confundem as partes do corpo que são apresentadas. Nagy e Molnar (2004) também demonstraram essa mesma habilidade, porém em bebês de 3 a 54 horas de vida. Nesse estudo, no entanto, uma análise psicofisiológica revelou que a imitação era acompanhada de uma segunda repetição do gesto, momentos depois, porém desprovida do aumento dos batimentos cardíacos que acompanhava a primeira imitação. Isso foi interpretado como uma tentativa do recém-nascido de provocar uma resposta imitativa no outro, tomando a iniciativa da interação, o que levou os pesquisadores a conceber uma nova definição para nossa espécie; homo imitans, homo provocans. A comunicação mimética, portanto, pode ser uma das primeiras formas de interação social, aquela que dá início aos demais processos que culminarão na entrada do sujeito na cultura. Como afirma Taussig (1993), a imitação é "a natureza que a cultura usa para criar uma segunda natureza" (p. xiii).

Outra linha de pesquisa envolvendo a questão da imitação intersubjetiva postula que esse fenômeno depende da ação de neurônios espelho, que disparam quando a ação é executada, mas também quando a mesma ação é percebida sendo realizada por outro indivíduo (GALLESE et al., 1996; RIZZOLATTI et al., 1996). Em outras palavras, a observação da ação mostrou-se capaz de suscitar a mesma ativação neuronal que a própria execução da ação, o que implica um paradigma distinto para a compreensão das relações sociais. Como ressaltam Sampaio, Leme e Lerner (2011) essa descoberta indica que o funcionamento psíquico é, em grande parte, imprescindivelmente social, fundado no entendimento direto e implícito das ações, emoções e sensações do outro.

A partir dessa perspectiva, uma série de fenômenos intersubjetivos que ocorrem na prática musical podem ser entendidos como relações entre a execução de ações e a observação dessas mesmas ações sendo executadas pelos demais. De fato, fazer música envolve movimentos como bater palmas, tocar instrumentos e cantar, mas também desperta em quem ouve a tendência a mover-se, seja dançando, batendo os pés, marchando, etc. Segundo Overy e Molnar-Szakacs (2009), isso significa que a música é percebida mais que como um simples sinal auditivo ou sequências intencionais de atos motores, pois inclui algum nível de compartilhamento e participação da experiência musical do outro. Em certo sentido, e de maneira inconsciente, sabemos implicitamente não apenas o que a música é, mas como é produzi-la, sentimos o musicar do outro como se fosse o nosso, e vivemos essa experiência como se costuma dizer, em nossa "própria pele". Essa proposição pode ser pensada em complementaridade à discussão 
sobre os processos de transmutação subjetiva a partir da alteridade apresentados anteriormente, justificando os efeitos terapêuticos da música intrapsiquicamente.

Já no nível intersubjetivo, considerações análogas são igualmente possíveis, dado que as interações musicais "envolvem imitação, aprendizagem, entendimento compartilhado e previsão e podem encorajar o contato visual, sorrisos, risadas e construção de vínculos, enquanto também permitem liderança, competição e expressão individual - todas elas poderosas experiências de aprendizagem social" (idem, p. 489). Consequentemente, esses autores formulam a hipótese de que imitação, sincronização e experiência compartilhada podem ser elementos chave no uso clínico da música, tal como acompanhamos ao longo das sessões da oficina.

Se acompanharmos as dificuldades experimentadas por crianças com autismo com relação à imitação intersubjetiva, essa ideia pode ser particularmente útil. Elas podem apresentar um atraso no surgimento das primeiras imitações, sendo que algumas, com maior gravidade, imitarão muito pouco os demais (WING, 1996), ainda que a imitação da manipulação de objetos possa, no entanto, ser menos prejudicada que a de movimentos e gestos corporais expressivos (HEIMANN et al., 1992). A existência ou não de comportamentos imitativos pode, como resultado, ser empregada como um critério diagnóstico, possibilidade que foi suscitada primeiramente por Kanner (1943). Para Stone et al. (1990), a imitação pode servir para diferenciar o autismo de outros transtornos comunicativos e do retardo mental. Nesse sentido, podemos entender algumas das dificuldades apresentadas por Mathias em imitar os movimentos dos demais em diversos momentos das sessões, como a coreografia do motivo do filme Tubarão (Fig. 26) e a dança caipira (Fig. 24). Nesse último caso, fica evidente o quanto é difícil para ele imitar a flexão do joelho, invertendo-a de acordo com seu ponto de vista, tal como havia sido percebido em crianças com autismo por Ohta (1987).

Essas dificuldades, contudo, não impedem que Camila e Mathias usem a imitação como uma forma de comunicação e interação ao longo de uma improvisação na qual o gesto de Mathias de inclinar o pau de chuva é imitado por Camila com um chocalho (Fig. 21, 22). Ainda assim, a frequência e a qualidade do comportamentos imitativos de Pablo podem resultar em um diagnóstico diferencial, já que os mesmos indicam uma riqueza intersubjetiva se comparado às demais crianças. Por vezes, suas imitações dos gestos ultrapassavam o que correspondia à coreografia em questão, incluindo a incorporação de gestos sutis, mais ligados à maneira pessoal de executar o movimento que ao gesto em si (Fig. 18).

Nesse quesito, Pablo difere daquilo que poderia ser esperado de uma criança com autis- 
mo. Mesmo no caso de uma insistência no diagnóstico, ele deveria que ser incluído em uma das pontas mais brandas do espectro. De fato, suas imitações são repletas daquilo que Hobson e Lee (1999) apontaram como o déficit central da síndrome com relação à imitação. Com experimentos em que se pedia que as crianças reproduzissem tarefas executadas de uma maneira "dura" ou "suave", eles verificaram que a dificuldade não era em imitar as ações, mas sim o modo como o experimentador as executava, isto é, seu estilo. Esse aspecto está menos ligado à finalidade da ação que aos afetos de vitalidade e a atitude que caracterizam o movimento, indicando que o problema não está vinculado à imitação, mas a um aspecto da vida psíquica ao qual a imitação está intimamente relacionada: a capacidade de identificar-se com o outro. Essa distinção foi feita por Freud (1921/1996), em cuja teoria do eu considerava que "um caminho por via da imitação, conduz da identificação à empatia, isto é, à compreensão do mecanismo pelo qual ficamos capacitados para assumir qualquer atitude em relação à vida mental” (p. 139). Segundo Hobson e Lee (1999), é a capacidade de identificação que está prejudicada no autismo, isto é, não apenas perceber, mas também assumir a qualidade expressiva do comportamento do outro.

Os fenômenos de imitação identificados, portanto, podem ser divididos entre imitações musicais e intersubjetivas, estas últimas compostas por imitações diretas e indiretas. Todas elas indicam que a imitação é um dos processos mais elementares do funcionamento psíquico com relação à capacidade de representação e ao laço social, cujos fundamentos podem ser encontrados no funcionamento neurológico e nos processos comunicativos verificados desde o início da vida. As questões suscitadas pelo conceito de imitação, no entanto, só podem ser completamente elucidadas se complementadas por uma discussão a respeito da identidade e, no nosso caso, da identidade sonora - como havíamos proposto no início desta investigação -, as quais receberão uma atenção maior a seguir.

\subsection{Identidade}

Para concluir esta discussão, apresentamos um último grupo de ideias que giram em torno do conceito de identidade e do modo como processos de identificação incidem sobre o funcionamento da oficina de música. Inicialmente, indicamos as origens do termo na filosofia, 
buscando para ele uma definição mais precisa, especialmente no que concerne à noção de identidade pessoal. Em seguida, apresentamos uma variante do conceito, fundada especificamente no campo da linguagem e sua função narrativa, para logo desenvolver o tema tal como aparece no desenvolvimento infantil e na música. Por fim, apresentamos a relevância desses achados para a clínica, discutindo também a relevância que intervenções baseadas no uso da música podem apresentar no estabelecimento de regras.

A identidade é um conceito fundamental na história da filosofia, e encontra um ponto de inflexão na obra de John Locke (1690/2016), de cujas proposições nos valeremos para esclarecê-lo. Esse autor parte de uma ideia geral de identidade como algo que se opõe à diversidade, ou seja, que se refere ao idêntico e à constância, àquilo que indica que uma coisa que existe no tempo e no espaço é ela mesma, e não outra, mesmo que sofra algum tipo de mudança. Uma árvore que cresceu de uma semente é sempre a mesma árvore, ainda que sua massa de matéria varie, dado que nas diversas etapas de desenvolvimento encontramos uma única organização de suas partes, o que garante a continuidade de sua vida, mas também permite dizer que se trata de uma só árvore. Isso também ocorre com um cavalo e um ser humano, mais gordos, mais magros, serão sempre o mesmo cavalo e o mesmo homem.

O avanço que Locke (1690/2016) imprime a essa discussão é a introdução do conceito de identidade pessoal, a partir da associação entre a ideia de identidade e a de pessoa, que passa a ser definida como "um ser pensante e inteligente, que possui razão e reflexão, e pode considerar-se a si mesmo como tal, a mesma coisa pensante em diferentes tempos e lugares". Surge nessa definição uma significação mais precisa de identidade, diferente da identidade física, porque inclui aspectos psicológicos como consciência, memória, inteligência e reflexão, mas também uma nova perspectiva: importa agora que esse ser possa reconhecer-se a si mesmo como tal, e não apenas que esse reconhecimento seja externo. As implicações dessa virada são fundamentais para compreender o estatuto do homem da modernidade até hoje, pois a identidade pessoal ultrapassa as mudanças morfológicas do corpo biológico e as variações morais do sujeito ético, colocando em cena uma instância psíquica consciente que integra, pela via da memória, as ações e pensamentos por vezes incongruentes de um indivíduo, possuidor de uma história, autonomia e responsabilidades.

De fato, tal como apontam Richter e Song (2005), grande parte da ideologia ocidental sobre o indivíduo repousa no pressuposto de que cada pessoa possui uma "identidade" distinta da de todos os outros, e que portanto é diferente da noção de um homem genérico, ou mesmo 
da de humanidade. Essa imagem se concretizaria na cédula de identidade, documento nos qual se registram as informações que permitem identificar um indivíduo. Desse modo, além de seus aspectos cognitivos, como memória e reflexividade, a identidade possui também componentes sociais - como o pertencimento a um grupo de identificação - e culturais e políticos - como nome, reputação, identidade jurídica, individualismo, ideal cultural, etc. Por ser historicamente localizado, esses autores afirmam que se trataria de um conceito de difícil tradução e compreensão para outras sociedades, sobretudo aquelas fundadas nos princípios da vida comunitária e da preponderância do social sobre o eu.

Para Ricoeur (1991, 1992), no entanto, existe um conceito dinâmico de identidade que conciliaria as mesmas categorias que Locke tomou como contrárias, ou seja, identidade e diversidade. Trata-se da identidade narrativa, à qual um sujeito ou uma comunidade acedem por mediação da função narrativa da linguagem. Como define esse autor, a pessoa

\begin{abstract}
entendida como um personagem de uma história, não é uma entidade distinta de suas "experiências". Muito pelo contrário: a pessoa compartilha a condição da identidade dinâmica peculiar à história contada. A narrativa constrói a identidade do personagem, o que pode ser chamado de sua identidade narrativa, na construção daquela da história contada. É a identidade da história que faz a identidade do personagem (p. 147-148).
\end{abstract}

Assim como na perspectiva de Bruner $(1991,2004)$ apresentada anteriormente, podemos equacionar a vida do sujeito com a sua história, ou as histórias que conta sobre si. E a identidade pessoal, nesse sentido, torna-se o produto dessa narração, não no sentido de uma realidade histórica, mas psíquica (FREUD, 1914/1996b), da permanência e constância da pessoa frente a história das suas mudanças. Apoiada na função narrativa, a identidade pessoal passa a ser uma construção, não só a partir da memória e da reflexão, mas das vicissitudes da lin guagem, em uma verdadeira poética de si. Na oficina de música, esse processo pôde ser identificado nas várias vezes em que as crianças se identificavam com os personagens das histórias, aproveitando os enredos para se apropriar ou sustentar narrativas de si. Essa associação podia explícita, no sentido do uso do pronome pessoal, mas outras vezes surgia sob a forma de metáforas, enquanto que em outras ainda era reconhecida a partir da nossa interpretação. Duas cenas de Pablo nas sessões ilustram esse argumento: a primeira quando, sob a figura do "caçador" de jacarés, ele assume a força e a coragem para matar o monstro assustador (Fig. 20); e a segunda, quando a história do rato ladrão desprende toda uma sequência na qual Pablo narra seus conflitos familiares na representação da família de roedores (p. 69).

Esses exemplos evidenciam um aspecto que é enfatizado por Ricoeur (1992) na teoria 
da identidade narrativa: o papel que a alteridade desempenha na construção da identidade pessoal, na medida em que ela representa o campo da diversidade que se entrecruza com a identidade na operação narrativa. Outros são o "caçador" e o rato, aquilo que não sou, mas que ao mesmo tempo passo a ser para me tornar aquilo que sou. Portanto, a identidade envolve uma dialética entre o eu e o outro, uma "espécie de alteridade que não é (ou não é apenas) o resulta do da comparação (...), alteridade de um tipo que pode ser constitutiva da individualidade como tal” (p. 3), e que encontra sua expressão mais radical na máxima de Rimbaud (1871/2006): “EU é um outro” (p. 155).

Se a questão da participação do outro é crucial na definição da identidade pessoal, isso ocorre porque, como veremos, esse processo está presente no desenvolvimento da criança desde os seus primeiros momentos. Desde essa perspectiva, os aspectos da alteridade participam da determinação inconsciente do psiquismo por meio do processo de identificação. Segundo Roudinesco e Plon (1998), a identificação é o "processo central pelo qual o sujeito se constitui e se transforma, assimilando ou se apropriando, em momentos-chave de sua evolução, dos aspectos, atributos ou traços dos seres humanos que o cercam” (p. 363). Trata-se de um processo que opera antes mesmo que o bebê possa realmente escolher as suas figuras de identificação. Nesse nível estão localizados, por exemplo, os nomes e sobrenomes, que geralmente já são definidos antes mesmo do nascimento. Como lembra Mezan (1986), logo após o nascimento, figuras de identificação são oferecidas ao bebê sob a forma dos enunciados de filiação de seus cuidadores, tais como "Meu bebê" e "Meu filho", ou aqueles que buscam inscrever o pequeno sujeito em uma rede discursiva investida pelo desejo dos outros: "Você é lindo", "Você é o futuro médico”, etc. Depois, surgirão as primeiras identificações com os cuidadores, que se tornam os objetos de amor do bebê. Essas identificações precoces têm um papel fundamental para que marcos do desenvolvimento da criança sejam atingidos, não apenas com relação às habilidades sociais, mas para a organização psíquica de forma integral, já que o processo identificatório forneceria as bases para a formação do eu. Como sintetiza Freud (1923/1976), o “caráter do eu é um precipitado de catexias objetais abandonadas e ele contém a história dessas escolhas de objeto" (p. 43-44). E assim progressivamente, com a crescente expansão do círculo social da criança, novas relações de identificação se estabelecem com pares, adultos, autoridades, instituições, etc., implicando transformações concomitantes no psiquismo.

Como apresentado na seção anterior, a noção de identificação também é importante na concepção de Hobson (2002), para quem identificar-se é assumir o ponto de vista do outro, a 
partir das ações e sentimentos expressados por ele. Em um primeiro momento, os bebês seriam capazes de coordenar suas experiências subjetivas com as de suas mães ou outros cuidadores. Em uma segunda etapa, as crianças passariam a se identificar com as atitudes dos outros e conseguiriam assumir sua postura emocional com relação a algo, sem perder a dimensão de seus próprios sentimentos e ações, a partir de sua própria perspectiva. $\mathrm{O}$ pensamento, portanto, emergiria dessas repetidas experiências de aproximação e distanciamento entre instâncias psíquicas distintas com relação a objetos e eventos, sintetizando as diversas perspectivas possíveis da realidade.

A dimensão da identificação, e não da expressão da identidade, portanto, parece estar no cerne dos processos terapêuticos da clínica do autismo. Isso pode ser verificado não só nos eventos de imitação, sincronização e coordenação de movimentos verificado entre os participantes, como também nos resultados de outras pesquisas que também estudam os efeitos de grupos dirigidos a essa população (LIMA, 2012; TIUSSI, 2012). Essas investigações, assim como esta, indicam que existe um grande potencial para que crianças com problemas no desenvolvimento encontrem em seus pares figuras de identificação que produzam efeitos determinantes no funcionamento psíquico. Os frutos dos encontros entre Pablo e William esclarecem esse argumento, dada a forma pela qual este último oferece ao primeiro possibilidades de produzir identificações fora da constelação familiar, resultando em comportamentos que pareceriam inesperados à primeira vista. Talvez o ambiente do grupo terapêutico seja mais propício que outros para que encontros dessa qualidade ocorram, como a escola, por exemplo. No entanto, algo da música parece facilitar que esses processos ocorram, mesmo em um caso grave como o de Camila, proporcionando situações em que surja algo da ordem do inesperado. Penso aqui na sessão na qual ela entra na sala ao ser avisada que estávamos começando uma canção que lhe interessava, interagindo conosco com acenos e sons na flauta (p. 72-73). Mais que uma imitação, podemos supor que essa interação possui uma qualidade de empatia e identificação com o grupo, no sentido do compartilhamento de uma atitude emocional entre todos.

Ademais, processos de identificação desencadeados na situação clínica podem ter importância mesmo para crianças com problemas fora do espectro do autismo. Isso fica claro nos jogos em que perguntávamos a cada um a sua comida favorita, a partir dos versos da segunda parte de "Ciranda, Cirandinha" (p. 66). Nesses momentos, era comum que elas repetissem as preferências de um adulto que as antecedesse, como se as escolhas desse adulto fosse usados como uma guia para o seu próprio desejo. A identificação de Sofia com Beatriz nessas oportu- 
nidades era evidente e literal, sugerindo que entre elas havia se estabelecido um processo de construção de identidade.

A discussão sobre o conceito de identidade adquire importância no contexto desta investigação na medida em que o debate sobre o manejo clínico das instâncias constitutivas da subjetividade por meio da música encontra nele um dos seus eixos centrais. Um dos primeiros movimentos nessa direção foi empreendido pelo psiquiatra suíço Ira Altshuler (1948) - considerado um dos pioneiros no uso da música aplicada ao tratamento de doentes mentais -, ao longo de sessões diárias de música com pacientes de um hospital psiquiátrico. Seu método consistia em práticas em grupo de conjuntos de ritmos com o objetivo de promover o interesse na terapia, seguidos de um período de canções melodiosas para encorajar a interação e a participação. Os efeitos eram diversos: sujeitos que antes praticamente hibernavam passavam a sacudir-se, dançar ou cantar, enquanto outros, avaliados como violentos, apaziguavam-se e empreendiam atividades, ou se acalmavam e às vezes até mesmo ninavam e dormiam. De uma maneira experimental, Altshuler delimitou a ocorrência de um padrão repetitivo: pacientes depressivos eram movidos pela música com andamento andante, enquanto pacientes maníacos, ou em estados de exaltação e entusiasmo, conectavam-se com uma música eufórica e um andamento allegro. Ao contrário do que se poderia intuir, a melhor forma de estabelecer um contato musical com um paciente maníaco não era com uma melodia suave e um ritmo tranquilo, mas o inverso. Mais tarde ele perceberia que o mesmo fenômeno se aplicava também a pessoas saudáveis em estados de tristeza, falta de vitalidade, agitação, etc. Denominou esse padrão de princípio ISO, derivado do prefixo grego ísos- (igual), definindo que, ao usar uma música idêntica ao estado de ânimo do paciente, o terapeuta facilitava a sua resposta mental e emocional.

Desde então, o princípio ISO tem sido objeto de questionamentos e polêmicas. Entre os estudos empíricos que avaliaram positivamente sua validade, pode-se se citar o experimento de Salamon et al. (2003), no qual sujeitos que ouviam seleções de suas músicas favoritas tiveram seus níveis de stress reduzidos, e os relatos clínicos de sua aplicação em um contexto terapêutico individual, como os de Bonny e Savary (1973) e Tyson (1981). O princípio ISO seria então frequentemente citado como pressuposto fundador da musicoterapia, sendo a base estratégica a ser seguida: usar a música para identificar e adequar-se ao humor de seu cliente, depois aproveitando o canal aberto por esse primeiro contato para empreender movimentos de recuperação e tratamento. Simples em conceito, o princípio ISO até hoje não se mostra facil- 
mente aplicável na prática, na qual depende da capacidade do terapeuta em determinar intuitivamente o humor do cliente, bem como da disponibilidade de um foco de atenção, para obter uma boa medida de seu estado de ânimo particular. Ainda que, segundo Short (1992), alguns indicadores - como expressões faciais, contato ocular, taxa de respiração, níveis energéticos e outras pistas não verbais, em adição a respostas vocais e verbais - pudessem auxiliar uma identificação positiva do funcionamento do principio ISO, outros elementos semiológicos puderam ser acrescentados. Isso se vincula a uma explicação neurofisiológica, como a sustentada por Trappe (2010), de que os sistemas cardiovascular e nervoso tenderiam a reagir à música, forçando o corpo a sincronizar-se com seu ritmo: para andamentos acelerados, o cérebro do ouvinte reagiria e a taxa cardíaca se tornaria mais rápida, enquanto o contrário acontece com andamentos lentos. Essa perspectiva psicofisiológica está em consonância com a teoria que o próprio Altschuler (1948) empregou para justificar organicamente os efeitos terapêuticos da música. Conhecida como "teoria do tálamo", ela defende que essa região do encéfalo possui a capacidade de ser atingida pela música antes que outros centros cerebrais, e que sua estimulação afeta as demais áreas do córtex, as vísceras e a musculatura, explicando porque a música está ligada tanto aos afetos e às emoções quanto ao pensamento e ao raciocínio.

A hipótese do princípio ISO foi posteriormente desenvolvida por Benenzon (1985, 1988, 2011), que a redefiniu como identidade sonora, ou princípio ISo. Para esse autor, ela se refere a todos os materiais não-verbais que fazem parte do psiquismo inconsciente. Em geral, manifesta-se sob a ideia de uma "música interior" (SMITH, 2014), em nossas preferências por determinada canção, estilo musical ou estrutura rítmica. Trata-se de um conglomerado de energias multissensoriais, em permanente movimento e com uma dinâmica particular que nos caracteriza e nos diferencia, sendo responsável por recriar nossa personalidade e nossa forma de ser (BENENZON, 2011). Nessa abordagem, a identidade sonora não é apenas um conceito orgânico e corporal, mas psico-corporal, integrado à cultura, ao ecossistema e à história do sujeito em seus diferentes níveis de constituição.

Entre os distintos níveis da identidade sonora, Benenzon (1988) identifica um ISo universal, que caracteriza e identifica todos os seres humanos, independentemente de seus contextos sociais, culturais e históricos, composto pelos sons do batimento cardíaco, dos movimentos de inspiração e expiração, a voz da mãe, o ranger das paredes uterinas, o fluxo sanguíneo, a água e outros que surgem da natureza e evolução do ser humano. No nível seguinte, haveria um ISo cultural, "produto da configuração cultural global da qual o indivíduo e seu grupo for- 
mam parte" (p. 33), que se altera conforme novos elementos sonoros e musicais são inseridos, enquanto os mais antigos são repassados ao ISo universal. Um exemplo seria a escala pentatônica, comumente encontrada nas estruturas sonoras de melodias e canções infantis.

Outro componente da identidade sonora seria o ISo grupal, produto das afinidades musicais latentes, desenvolvidas em cada um dos membros de um grupo humano, relacionado à identidade de uma etnia. Encontraríamos aí todas as canções próprias de um povo, seus hinos, acompanhamentos de rituais e cerimônias, músicas tradicionais, etc. Já as pequenas mudanças que se produzem a cada dia, por efeito das circunstancias ambientais específicas ou psicobiológicas do indivíduo, integram o que Benenzon define como ISo complementário, ou seja, as partes da identidade sonora que se compõem nos encontros que se estabelecem ao longo da vida. Elas poderiam durar somente alguns momentos, desaparecendo do inconsciente sem reunir ou resumir quaisquer características especiais ou identificatórias. Ou, por outro lado, poderiam inscrever-se no psiquismo, caso associadas a uma carga afetiva suficientemente intensa. Por fim, haveria um ISo gestáltico, que integra os demais níveis e caracteriza formalmente a identidade sonora do indivíduo, organizando o patrimônio sonoro genético herdado de seus antepassados, os sons da vida intrauterina e da primeira infância, e todos os componentes culturais e complementários que o sujeito acumula em seu desenvolvimento.

Benenzon (2011) defende que esses diferentes componentes da identidade sonora se organizam em um movimento, no qual os elementos constituintes ocupam um nível, mas também transitam entre os demais, de modo que se poderia falar de uma espiral dos ISos. A identidade sonora teria portanto uma dinâmica ao mesmo tempo filogenética e ontogenética, e os ISos universal e cultural teriam se enriquecido na medida em que absorviam as características do meio circundante do individuo. Essas novas qualidades se entrecruzariam nos ISos complementários e gestálticos que, ao longo do tempo, seriam gradativamente incorporados ao ISo universal da espécie.

$\mathrm{Na}$ prática da musicoterapia, o princípio ISO é aplicado sempre que o terapeuta busca uma abertura do canal de comunicação com seu paciente, identificando e respeitando o seu ISo para depois enriquecê-lo com experiências que incluam novos sons e ritmos, "transformando o interior musical do indivíduo, metamorfoseando-o musicalmente" (SMITH, 2014). Isso também é defendido por Lee (2003) quando afirma que, "apesar de a preferência musical ser importante, devemos também ter o potencial de fornecer outros caminhos musicais que irão equilibrar e tornar o processo terapêutico mais direcionado, potente e esteticamente pode- 
roso" (p.xvi).

Nesse sentido, a dimensão complementária da identidade sonora deve ser enfatizada como abertura permanente aos processos de identificação. É o que pode ter o ocorrido na intervenção orientada à repetição de uma figura rítmica por William, que aproximamos anteriormente à noção de ideia fixa (Fig. 5). Ao apresentar a possibilidade de incluir um material com o qual ele havia se identificado tão fortemente em outra canção, tanto eu quanto a música nos oferecemos como suportes para que um novo processo identificatório ocorresse, o que efetivamente conduz ao fim da repetição estereotípica (Fig. 6). Poderíamos entender, logo, que esse material teria retomado sua circulação na espiral de sua identidade sonora.

Essa abordagem complexa recupera um dos aspectos mais instigantes da música, isto é, que ela seja um fenômeno necessariamente individual nos níveis perceptivo, cognitivo, produtivo, intelectual, corporal, mas também social e cultural, isto é, desfrutada e produzida em grupo, vinculada a uma tradição, etc., reveladora tanto de nossa singularidade quanto do pertencimento a uma ordem coletiva. Tal característica se apoia na ideia de que os significados veiculados pela música se relacionam a um conhecimento implícito que envolve hábitos inconscientes - procedimentos e padrões próprios à cultura - que derivam da percepção e interação com os movimentos corporais propositais coordenados do outro (GRATIER; TREVARTHEN, 2008). É num mesmo ato que a música envolve o sujeito, o outro e a cultura. E essa capacidade das experiências musicais compartilhadas de engendrar formas intensas de comunhão e entendimento, desde os primeiros estágios da vida até o seu desfecho, está intimamente ligada aos processos de identificação como produção de identidades. São nesses encontros que a alteridade se faz presente, e sua participação no psiquismo se torna aceitável. Em função dessa dialética, a identidade sonora não deveria ser considerada como uma espécie de essência subjetiva, mas como o trabalho coletivo de compor as histórias que contamos na música, as narrativas musicais de nós mesmos.

De fato, ao longo da prática de canções e encenação de representações narrativas, todos assumimos os papéis que nos oferece a cultura. Podemos ser um índio que, navegando junto com seus companheiros, se vê frente a um jacaré que se aproxima e quase faz tombar seu bote, ou o aviador que cai em uma ilha deserta e descobre a fauna e os moradores do local, ou o herói que salva a princesa presa em meio a uma armadilha. Os personagens encarnados pelas crianças acarretam a elas uma realidade narrativa com novas situações e dificuldades, mas também novas forças e habilidades, com as quais elas ampliam seu repertório de possibilidades. 
Essa identificação consiste na riqueza de assumir um papel em uma narrativa. Elas podem agora perceber elementos e significados que não eram acessíveis, tanto em relação ao outro e aos objetos, e tecer entre elas formas de percepção e ação distintas das quais estão acostumadas, e que talvez nunca haviam considerado para si mesmas. $\mathrm{Na}$ medida em que se desenrola a fantasia, os problemas e suas soluções imaginárias tornam-se agora reais e vice-versa, e as crianças revelam na brincadeira sua facilidade em se tornarem outras.

Uma ressalva, porém, pode ser feita na forma de uma crítica no modo como o tratamento de Camila foi conduzido. Muitas hipóteses foram feitas com relação aos obstáculos enfrentados, que se traduziam na sua frequente recusa em participar das atividades da oficina, ou sua insistência em abandoná-la em algum momento da sessão. Considerou-se que se tratava de situação na qual havia excessivas convocações a participar ativamente do grupo, ou na qual a intensidade sonora afetava sua sensibilidade, o que talvez fosse demasiado exigente para ela. Nesse sentido, o dispositivo poderia ser mais efetivo caso pensado em um esquema de "portas abertas”, no qual as crianças têm a liberdade de circular entre espaços onde distintas atividades ocorrem simultaneamente. De um certo modo isso ocorreu, ainda que de maneira limitada ou não sistematizada, dado que questões de espaço nos forçavam a organizar um ambiente separado na mesma sala ou em espaços improvisados. Por outro lado, as dificuldades experimentadas por ela poderiam ser também creditadas a uma falta de momentos em que pudesse expressar-se espontaneamente, obliterados por nossas demandas de que interagisse com o grupo. É possível que o dispositivo tenha falhado na composição de um ISo complementário junto a ela, um trabalho que Lecourt (2011) define como a difícil passagem do outro ao Outro. O estabelecimento de um intervalo de som e a construção de uma relação terapêutica estiveram, no seu caso, à margem das vicissitudes da oficina e da investigação.

Apesar disso, em diversos momentos pudemos presenciar como ela, assim como as demais crianças, pôde estabelecer algum tipo de laço social tecido pela música. A participação delas na oficina de música não é agradável ou fácil na maior parte do tempo. Elas permanentemente têm que se ajustar às necessidades e demandas dos demais e da própria estrutura da atividade prática, o que implica em muitas vezes ter que desistir daquilo que mais queriam fazer, ou negociar uma maneira para que isso possa acontecer dentro da estrutura do grupo ou da prática. $\mathrm{O}$ trabalho com William é um exemplo claro. Um detalhe é que isso só parece ter sentido porque as crianças demonstram gostar da prática, e têm que ajustar-se a ela para conservá-la e dela participar. Regular-se, nesse sentido, é encontrar o melhor lugar para se estar, 
como a presença de Camila na roda, primeiro longe, depois trazida para o centro da roda, e finalmente encontrando um lugar em sua periferia (p. 75).

Ainda com relação à questão da alteridade e da identificação, outro aspecto que se mostrou importante foi a flexibilidade estrutural da música em acomodar e transformar-se rapidamente, tanto temporal, formal e tematicamente, como um jogo. A tarefa do terapeuta, nesse sentido, parece ser a de encontrar a dose certa entre a frustração e realização dos desejos de cada um, ter uma atitude facilitadora e afirmativa em lugar da negação corretiva, apresentando-se como uma figura adequada de identificação. Isso garante que o ajustamento seja àquela situação e à produção de uma experiência compartilhada, e não a fatores estéticos, morais, etc. externos à situação, o que faria do mesmo uma normalização e do terapeuta um agente normativo. Nada disso se trata aqui. Apesar de sempre garantir as condições de segurança e de realização da proposta, nosso trabalho clínico tinha como objetivo facilitar a reorganização do campo de relações e significações de cada criança, sabendo de antemão as dificuldades que sujeitos afetados pelo autismo podem experimentar em adequar-se às normas e regras sociais, àquilo que o Outro espera delas. Mais que mandar e obrigar, buscamos sugerir e convidar, para que elas mesmas sintam-se dispostas a encontrar o seu caminho.

Nesse percurso, a noção de tratamento do Outro (ZENONI, 2002) se constituiu como um dos eixos mais importantes de leitura do processo terapêutico e das intervenções clínicas. Entende-se que a construção de um Outro alternativo, por meio da montagem institucional, seria uma consequência lógica na direção de tratamento orientada a esses distúrbios. Nessa nova modalidade de funcionamento da ordem simbólica, distinta daquela invasiva à qual o sujeito se esforça em barrar, uma vertente "positiva” da presentificação da cultura poderia suplantar as dificuldades que essas crianças enfrentam no encontro com o outro. Como afirma Bernardino (2006), por meio de um

trabalho lento, difícil, desafiador, faz-se a oferta de um outro/Outro que poderia não
ser ameaçador, destrutivo, aniquilador, mas que ao mesmo tempo poderia receber es-
tas ameaças, esta destrutividade, esta aniquilação, na cena terapêutica. Um semelhan-
te/um exterior que poderia ser confiável, porque propõe algo diferente da solidão:
propõe compartilhar uma experiência, seja ela qual for (p. 6).

O tratamento do Outro implica que a doença decorre do conflito entre a constituição biológica e psicológica do indivíduo e o meio em que ele vive, e que por isso pode ser abordada "não por intervenção terapêutica, mas por mudança de contexto material ou cultural da pessoa" (RUUD, 1990, p. 15). A cultura pode ser então "sadia" ou "doente", e fazer parte do tratamento. Como sintetiza Lima (2012), a música, 
nesse sentido, possuiria uma particularidade interessante, na medida em que ao mesmo tempo em que não é dirigida diretamente à criança na forma de uma demanda ou de um saber, também não pode ser evitada, chegando ao seu destinatário. Com isso, faz-se um convite para que a criança possa gozar desse objeto musical, mas não à sua própria maneira, mas necessariamente em um jogo, já que esse objeto está também inscrito num campo exterior ela, o campo do Outro (p. 60).

A particularidade da experiência musical - e que a aproxima do tratamento do Outro seria então essa capacidade de promover uma situação onde a "interseção, negociação e afirmações autônomas conflitantes de duas 'agências' individualizadas" (MILLS, 2016, p. 25) é menos conflitante, ou mais tolerável. Essa dimensão fica evidente no trabalho com William dirigido a estabelecer um esquema de regras de tocar (scheme of play rules) (WIGRAM, 2004), de modo determinar zonas estruturadas de adequação e transgressão, e assim conferir algum tipo de significado ou direção às experiências musicais interativas. Desde o início do tratamento, ficou claro que a maneira de firmar acordos e regras era menos eficiente pelas ordens e pedidos verbais que pela introdução de uma estrutura musical. Ele, por exemplo, não deixava de tocar a célula rítmica para responder aos nossos pedidos de explicação sobre o que era aquilo e para que servia. Pouco ineficazes eram também as tentativas de estabelecer uma ordem do tipo "Há uma hora para tocar e uma hora para falar" ou "Enquanto um fala, o outro escuta". Por outro lado, a ordem de alternância tutti-solos da canção de abertura era praticamente sempre respeitada por ele. A estrutura de alternância forte-fraco, por outro lado, teve um efeito menor e menos frequente. Ainda assim, como vimos na análise da canção "Cocoricó" (Fig. 14), chama a atenção que ele tenha respondido menos à ordem de "agora bem baixinho" que aos diminuendi forçados pelo violão. Isso indica que a imposição de uma regra de tocar possui um efeito distinto quando comunicada por meios musicais.

A indicação do momento de cada um tocar nas alternâncias tutti-solos foi uma maneira de, ao mesmo tempo em que se garantia um turno de expressão individual para cada um, organizar o tempo e tornar possível que William respeitasse o momento dos outros, escutando em silêncio aquilo que eles tinham a dizer. Podemos interpretar a partir de seu comportamento mais comum que, para ele, a possibilidade de não ter seu momento e lugar era insuportável, gerando uma angústia da qual ele se defendia ocupando tantos espaços (físicos e sonoros) quanto lhe fosse possível. A estrutura da canção, por sua vez, ao oferecer uma ordem de solos definida pelas posições na roda, dando a cada um o momento de se expressar, pode ter lhe garantido uma posição, um momento que poderia ser antecipado e aguardado, eliminando a necessidade de uma ocupação constante e permanente. Ali, junto com seus companheiros, ele 
existia não só na medida em que falava e se movimentava, mas também enquanto aguardava e escutava o outro.

Apesar dos efeitos diferenciados entre a regra de tocar e a regra verbal, ambas possuem uma orientação comum: coordenar a ação conjunta por meio de uma estrutura de organização do comportamento. No entanto, apesar de ser necessária e ter seus efeitos específicos, a regra verbal parecia ter um efeito limitado em William. Ele não respeitava os combinados e os chamados de atenção e advertências muitas vezes eram levados em consideração por um curto período de tempo e depois esquecidos. Conversas mais aprofundadas sobre os motivos de determinado comportamento ou a insistência para que ele pedisse desculpa a outra criança, por outro lado, tinham um efeito demasiado intenso, e o conduziam a uma situação de angústia e paralisia. Parecia não haver um ponto intermediário em que a lei produzisse um efeito e ao mesmo tempo fosse suportável. A regra de tocar, por sua vez, compartilhava os mesmos princípios de organização da conduta. Contudo, suas leis não eram necessariamente explicitadas de forma verbal. No caso da regra de tocar "bem baixinho", muitas vezes se avisava que o próximo verso seria cantado dessa forma, e em outras o efeito era obtido por diminuendi na dinâmica do violão que acompanhava o grupo (Fig. 14). Havia problemas que surgiam nessa situação, e muitas vezes William voltava a soprar a flauta com força ou a golpear o pandeiro na cabeça, porém houve também alguns êxitos. De uma maneira geral, a impressão é que o desvio da regra de tocar afetava o seu juízo estético, retirando da música as qualidades que tanto lhe agradavam. $\mathrm{O}$ sorriso que acompanhava essas transgressões era curto e hesitante, eu diria até mesmo constrangido, ao contrário das risadas e gritos que acompanhavam os atos de jogar coisas para o alto ou atacar um companheiro. Na estrutura do jogo e da música, no entanto, ele podia agir de uma maneira distinta. Era o indício que havia um tratamento em operação, que não se dirigia diretamente a ele, mas a todo o seu campo de relações e significações.

Esses efeitos terapêuticos provavelmente seriam impossíveis caso não operasse no grupo uma dinâmica de identificações que, se por vezes eram sustentadas pelos adultos, em muitos momentos estavam a cargo dos próprios participantes, o que reforça a indicação do grupo terapêutico como método de intervenção para o autismo. As atividades musicais parecem ter um papel fundamental nesse sentido, ao criar um ambiente e uma estrutura organizada das interações que tanto facilitam quanto promovem a abertura segura ao encontro com a alteridade e a diferença. $\mathrm{Na}$ música, é possível e tolerável buscar maneiras alternativas de sentir, pensar, agir e existir. Talvez, no futuro, as experiências que tivemos juntos possam ressurgir na forma 
de alguma lembrança. Minha esperança é a de que, mesmo indiretamente, elas terão contribuído para que essas crianças enfrentem os desafios que encontrarão adiante, buscando companhias para explorar e desfrutar o mundo, e inventem outras formas de serem outras, ou seja, elas mesmas. 


\section{CONCLUSÃO}

A título de conclusão, esta última seção apresenta um resumo dos principais resultados obtidos pela pesquisa. Em primeiro lugar, será apresentada uma avaliação da metodologia empregada e suas limitações. Em seguida, os dados obtidos serão debatidos sob a luz da hipótese e dos objetivos anunciados na introdução. Por fim, as contribuições da pesquisa serão listadas, tanto no que se refere aos resultados que podem ser aproveitados para outras pesquisas, quanto ao modo mais geral como relacionamos música e subjetividade.

Com relação ao método empregado, um primeiro destaque pode ser dado ao emprego dos grupos terapêuticos. Para além de seus objetivos clínicos, eles podem ser considerados ferramentas úteis no estudo da experiência musical, de um modo geral, já que permitem a observação, acompanhamento e intervenção no nível da prática, semelhante àquela que os participantes poderiam ter em casa, na escola, em oficinas de educação musical, etc. Se bem esse método proporciona uma compreensão de como as crianças agem dentro de um contexto social mediado pela música, ele pode não ser o mais indicado para o estudo das caraterísticas acústicas de verbalizações, por exemplo, já que dificilmente se consegue obter uma amostra pura desses objetos, sem a concorrência de sons ambientes ou produzidos pelos demais participantes. É nesse sentido que a presente pesquisa pôde oferecer resultados inconclusivos a esse respeito, não obstante a indicação de que o mesmo pode ser um campo fértil para pesquisas baseadas em outros métodos de estudo e observação.

Outro destaque é dado ao uso de instrumentos conjugado com a proposta de cantar em grupo. Um certo apelo a eles pode ser identificado pelo fato de, apesar de os procedimentos serem constituídos em sua maior parte pela recriação de canções, foram poucos os momentos em que os participantes não carregavam consigo algum instrumento musical. Poucas crianças cantavam durante as sessões, e muitas vezes o faziam segurando um instrumento, mesmo sem tocá-lo. A análise dos vídeos sugere também que o uso de instrumentos por vezes emula a prosódia dos versos cantados, possivelmente tendo um valor de fala na prática musical. Isso pode ser efeito das canções de abertura e encerramento, nas quais cada um necessariamente apresentava seu instrumento, mas pode indicar um mecanismo de expressão próprio da música. Os instrumentos foram geralmente usados para: marcar a pulsação das canções, reproduzir a prosódia dos versos e acompanhar a melodia das frases (em ordem decrescente de frequência). 
Cada criança parece ter uma preferência por um desses usos, assim como por instrumentos específicos. O comportamento mais frequente com relação aos instrumentos, no entanto, é a exploração. Eles eram manipulados, desmontados, montados novamente, e tocados de diversas maneiras, resultando em uma variedade de sons, cuja descoberta era motivo de surpresa e interesse.

O uso do registro audiovisual mostrou-se positivo para os propósitos da investigação. Já a seleção de cenas para o estudo de caso é algo que passa pelo crivo do pesquisador, e nesse sentido está sujeita à sua interpretação. Pode-se, por outro lado, ressaltar o papel fundamental que as reuniões da equipe clínica exercem no enriquecimento desse processo, tanto pela multiplicação de perspectivas do trabalho clínico, quanto pela discussão e construção conjunta dos casos. A AP3 anos também demonstrou grande utilidade no auxílio ao processo de seleção e análise, já que suas categorias orientam a percepção e a leitura dos eventos ocorridos em atendimentos, tal como apontado por Lima et al. (2008), Pinto (2009) e Lima (2012).

A transcrição se mostrou eficaz na representação das cenas clínicas de um modo complementar ao registro verbal. Ela permite a análise e a compreensão dos fatores propriamente musicais das interações, enriquecendo os estudos de caso, tal como enfatizam autores como Barcellos (2009) e Wigram (2004). Do mesmo modo, considerou-se que as ilustrações também cumpriram com o propósito de demonstrar visualmente as cenas descritas, ampliando a sua compreensão. Cabe ressaltar que ambos recursos garantem o sigilo da identidade dos participantes, satisfazendo as exigências éticas para este tipo de pesquisa.

A microanálise, por sua vez, mostrou-se adequada ao estudo dos eventos e processos musicais ocorridos. Ela pôde ser empregada como suporte dos métodos descritivos clássicos, sem suprimir as impressões subjetivas do investigador, que são a sua característica fundamental. $\mathrm{O}$ estudo de caso a partir do registro verbal e da microanálise evita que o primeiro perca sua objetividade e que a segunda omita a espontaneidade que está implicada na prática musical. Apesar do inconveniente de exigir grande esforço e tempo do pesquisador para ser realizado, esse método apresenta diversas vantagens. Sua aplicação não se restringe apenas ao estudo dos eventos e processos, podendo ser também usado na seleção das cenas que serão submetidas à análise, já que oferece uma percepção global da situação registrada. Isso amplia a percepção de detalhes que dificilmente chamariam nossa atenção na situação concreta em que ocorreram. Um exemplo é quando, ao contrário do que pensávamos, descobre-se que Camila realmente havia tocado o violão, de forma muito sutil, em resposta a um pedido nosso. Nesse sentido, o 
apoio audiovisual ao trabalho clínico e científico pode ser vantajoso, na medida em que amplia as possibilidades perceptivas de terapeutas e pesquisadores, trazendo à tona elementos que de outra forma permaneceriam inconscientes.

As limitações metodológicas da pesquisa, por sua vez, concentram-se fundamentalmente em sua dimensão amostral. Por se tratar de estudos de caso a partir de um grupo único, com um número reduzido de participantes e por uma duração limitada, nossos resultados apresentam pouca longitudinalidade e transversalidade. É possível, no futuro, reproduzir os procedimentos com outros grupos e/ou por um prazo maior de tempo ou, o que seria igualmente interessante, estudar o efeito das canções no tratamento do autismo em outras situações ou dispositivos, como as interações musicais entre pais e bebês ou educação musical especial.

No entanto, contrário à ideia de que as restrições amostrais limitaram o alcance da pesquisa, foi possível realizar um estudo de caso em profundidade para cada um dos participantes. Além disso, o registro audiovisual das sessões produz uma grande quantidade de material, que deve ser visto e revisto várias vezes para ser microanalisado. É possível que uma amostra maior de registros audiovisuais exija a participação de mais pesquisadores para viabilizar sua microanálise.

Com relação à pesquisa teórica, uma das dificuldades enfrentadas foi que os aspectos ressaltados nas sessões da oficina configuravam objetos de estudo que se estendiam por um amplo espectro de disciplinas: filosofia, antropologia, musicologia, musicoterapia, teoria literária e semiótica, neurociência, psiquiatria infantil, psicanálise, psicologia do desenvolvimento, etc. Isso exigiu a inclusão de uma variedade de discursos, teorias e métodos de pesquisa para que os mesmos pudessem ser minimamente compreendidos. Certamente, poder-se-á lamentar que alguns dos pontos não tenham sido explorados com maior profundidade ou acompanhados em sua evolução na obra dos respectivos autores. No entanto, as discussões podem contribuir para uma cartografia do conhecimento e dos debates atuais pertinentes, o que pode orientar futuras investigações que pretendam investigar em mais detalhes um ou outro dos aspectos selecionados.

Outra limitação da revisão bibliográfica é a sua posição na história dos conceitos analisados. Termos como "autismo", "música", "canção" e "ritmo" tiveram que ser aprofundados para fornecer subsídios a sua discussão. O conceito de "transtorno do espectro do autismo" mostrou-se limitado na definição do recorte de pesquisa, tanto em seus aspectos empíricos quanto teóricos. Por se tratar de um conceito da medicina psiquiátrica, ele também delimita um cam- 
po restrito de discussão teórica. Com relação aos participantes, ele virtualmente exclui aqueles que não foram diagnosticados ou cujo diagnóstico ainda não foi definido. $\mathrm{O}$ termo autismo parece ser mais indicado para sustentar, de uma maneira mais abrangente, estudos sobre essa população.

Uma análise genealógica também indica que os discursos sobre o autismo não evoluem apenas no sentido de uma progressiva compreensão dos fatores etiológicos, diagnósticos e terapêuticos envolvidos, mas também evidenciam relações de poder entre grupos que defendem interesses particulares. Como vimos, esses discursos não possuem somente um caráter descritivo, como também um aspecto produtivo, já que determinam os modos como pensamos e atuamos com relação a esses sujeitos. Uma década atrás, quando esta pesquisa dava seus primeiros passos, o diagnóstico médico dado a essa população era o de distúrbio global do desenvolvimento, enquanto hoje nos vemos diante de um espectro do transtorno autista. Quais serão as denominações que estarão em voga daqui a 10, 25, 50 anos? Inevitavelmente, qualquer contribuição será limitada pelos estudos genéticos e biomédicos por vir, o que fará da tarefa de combinar nosso conhecimento atual com essas informações algo provavelmente difícil. Como será feita essa articulação com novas classificações, por exemplo, se o espectro voltar a ser dividido em, digamos, 5 ou 10 entidades distintas?

De todo modo, a partir da discussão dos estudos de caso e da revisão narrativa da literatura, algumas considerações podem ser tecidas com relação ao papel da música, em geral, e das canções, especificamente. Em primeiro lugar, a oficina de música confirma os resultados de diversas outras pesquisas que afirmam que a música pode facilitar as interações de indivíduos com autismo. Acompanhadas pela música, as crianças que participaram deste estudo tiveram uma série de experiências sociais que, sem ela, seriam distintas ou impossíveis. Essas interações revelam a operação de mecanismos intersubjetivos de sincronização, coordenação, imitação e identificação, indicando que, não obstante os problemas comportamentais, sociais e de linguagem, uma parte da sensibilidade social está conservada nesses casos sob a forma da musicalidade comunicativa. Apesar de parecerem mudanças sem significância, para aqueles que trabalham na clínica do autismo tais resultados podem ser entendidos como grandes avanços. Tendo em vista as dificuldades associadas a essa condição, a própria possibilidade de participar da oficina, de sustentar uma atividade e incluir-se em um grupo, já deveria ser considerada um efeito terapêutico razoável.

Nos estudos a respeito do uso clínico da música, em especial no tratamento do autismo, 
encontramos uma ideia de música orientada ao seu aspecto não-verbal ou pré-verbal. Seus efeitos terapêuticos, nessa perspectiva, dever-se-iam à sua posição de anterioridade e/ou exterioridade com relação à linguagem, o que supostamente permitiria tanto o acesso a experiências pré-verbais quanto a comunicação com sujeitos não-verbais, estabelecendo uma interação em um nível emocional e relacional, distinto das interações caracterizadas pelo uso da linguagem verbal. "O enquadre não verbal", como resume Benenzon (1985), "é o que permite a esta [criança com autismo] estabelecer os canais de comunicação" (p.140). Dispositivos fundamentados nessa concepção podem incluir a comunicação verbal de uma maneira restrita, ou mesmo não incluí-la entre seus procedimentos.

Porém, como apresentado na discussão, desde uma série de perspectivas, a comunicação não-verbal não está isolada do campo dos fenômenos linguísticos. Para além do pensamento dicotômico, as relações da palavra falada com a palavra cantada, e vice-versa, indicam que entre as dimensões verbal e não-verbal da comunicação existem semelhanças e fatores comuns. Mais que isso, o que o desenvolvimento das expressões linguísticas e musicais revela é que ambas possuem uma mesma raiz: a musicalidade comunicativa. Trata-se, portanto, distinções que não se baseiam em aspectos estruturais, mas em convenções culturais e orientações localizadas e hierarquizadas, ou seja, que pouco resultam de uma distinção objetiva. Talvez, essas dicotomias sejam ainda mais irrelevantes frente a conduta infantil, se pensarmos não só como suas brincadeiras estão repletas de ritmos e inflexões da voz, mas que até os sons dos instrumentos podem ser uma forma de cantar. Existe algo de não-verbal até mesmo naquilo que consideramos como verbal, na medida em que podemos identificar no discurso as dimensões da fala e da voz, a partir de suas qualidades musicais. Essas considerações, portanto, não sustentam a hipótese de que o aspecto não-verbal da música seja o fator determinante de seus efeitos terapêuticos. Nossos resultados indicam que é a relação com a alteridade por meio da musicalidade comunicativa que sustenta a intervenção clínica na oficina de música para crianças com autismo.

Em síntese, as práticas musicais que envolvem canções e jogos musicais podem apresentar efeitos positivos a essa população, os quais podem ser compreendidos em suas dimensões intersubjetiva, intrapsíquica e sociocultural. Em um nível intersubjetivo, destaca-se o modo como a experiência musical proporciona um encontro organizado com a alteridade, de modo que diversas atividades da oficina geram possibilidades de engajamento nos motivos do outro, assim facilitando a interação social. Danças e jogos orientam processos de imitação, sincronização e coordenação rítmica de movimentos. Imitações intersubjetivas ocorrem nas díadas cri- 
ança-adulto e criança-criança, mas no último caso encontramos gestos mais sutis e implícitos, indicando que uma criança pode oferecer à outra modelos que não são disponibilizados pelos adultos.

O convite para formar uma roda desde o início do grupo mostrou-se bastante eficaz para manter a coesão do grupo e o foco na atividade a ser realizada, ainda que demandasse certo esforço por parte dos coordenadores. A estratégia de não exigir que as crianças permanecessem na roda, por outro lado, possibilitou que algumas delas participassem das atividades à sua maneira, encontrando um lugar e uma distância possíveis para estar com o grupo. Mesmo fora da roda, elas ainda assim interagiam com os demais, tocando um instrumento, movimentando-se em coordenação ou dançando. Por outro lado, o trânsito de algumas crianças fora da disposição em círculo produziu um efeito de desestruturação no grupo, reforçando a necessidade de incorporar esses gestos às propostas do dispositivo, integrando-as de alguma forma nas atividades realizadas.

Ainda assim, uma das crianças do grupo apresentou uma frequente resistência a participar das sessões do grupo. Diversas hipóteses foram levantadas com relação a isso, porém nenhuma mostrou-se completamente explicativa. A ausência e a presença da mãe pareceu ser um fator importante, já que diversas vezes ela saía da sala para buscá-la. O convite para que ela permanecesse na sala de atendimento foi útil nesse sentido, apesar de nas primeiras sessões a participante ter ficado quase que permanentemente ao seu lado. Sua presença, no entanto, possibilitou uma progressiva aproximação ao grupo e um distanciamento da mãe, ainda frequentemente se voltasse para verificar se ela ainda estava ali. Nas últimas sessões, ela já participava de praticamente toda a duração das sessões. Outras hipóteses, como o alto volume dos instrumentos, a duração das atividades ou mesmo a própria situação de grupo ou de atividade musical, aparentam ter um valor explicativo menor, tendo em vista que ela se aproximava do grupo sem que esses aspectos fossem modificados, e pôde engajar-se em atividades interativas com os demais, o que pelos seus sorrisos e vocalizações entendemos que lhe produzia alegria e satisfação.

Desse modo, deduzimos que a experiência musical pode ser terapêutica devido a seus efeitos intrapsíquicos. Isso se deve não apenas ao prazer que a música produz em quem a escu ta - sobretudo se consideramos a atração exercida por ela, mesmo em crianças que apresentam um maior isolamento social -, mas porque ela fornece parâmetros formais que incidem sobre a experiência subjetiva, alterando o modo como percebemos, interpretamos e avaliamos a reali- 
dade, ativando determinados sentimentos e sensações, intensificando nossos níveis energéticos e de concentração. Tais contornos de ativação operam como um envelope da experiência, que não remete ao seu conteúdo, mas à sua forma, de modo que as diversas qualidades expressivas que caracterizam e imprimem sentido aos sons e movimentos corporais também modulam formas do brincar e da fantasia. Essas modalidades da experiência correspondem a uma nova percepção da realidade, de modo que, com a música, as crianças realmente podem sentir-se a si e ao mundo de outro modo, e realizar aquilo que antes podia ser impossível. Ademais, a musicalidade da subjetividade infantil, inerente à espontaneidade e intuitividade do seu musicar, torna essas formas de fácil compartilhamento e assimilação. Isso permite uma intervenção por meio da música que, ao mesmo tempo em que flexibiliza motivos e figuras musicais, pode ser tolerada pela criança.

Os participantes demonstraram vários graus de sensibilidade à música, por vezes chegando a identificar uma estrutura rítmica ou melódica, tanto vocal quanto instrumental, e reproduzindo-a em seu próprio instrumento, o que poderia ser considerado uma forma de "tocar de ouvido". Além disso, eles se mostraram amplamente capazes de expressar-se por meio da música, o que leva a crer que as figuras musicais podem oferecer uma representação a conteúdos do psiquismo que todavia permanecem informes. Contudo, o desenvolvimento das células rítmicas em motivos e figuras musicais pode ser algo problemático, devido a uma rigidez com relação a algum motivo temático, histórico, ideia musical ou célula rítmica. Essa inflexibilidade dificulta que esses elementos sejam encadeados com outras figuras e concorram em um desenvolvimento musical. Verificou-se, no entanto, que quando esses elementos eram introduzidos em outra estrutura musical, terminavam sendo transformados para adaptar-se àquela realidade estrutural específica (intensidade, andamento e ritmo), o que favoreceu a atenuação das estereotipias e figuras autistas.

Ainda em um nível intrapsíquico, as atividades da oficina se relacionam ao desenvolvimento da função psíquica da voz e movimentos de emergência subjetiva na ordem da linguagem. De fato, algumas crianças frequentemente apresentavam verbalizações com uma qualidade vocal particular e distinta, em termos de entonação e prosódia, daquela que usualmente em pregam durante as sessões. Chama a atenção que essa "outra voz" surge em momentos de grande excitação, seja por uma brincadeira mais enérgica, ou ao apresentar motivos que parecem afetivamente mais carregados que os demais. É possível que essas características sejam imitadas de pessoas ou personagens, o que tampouco pode ser confirmado, dada a variedade de situ- 
ações e contextos nos quais podem surgir. De qualquer modo, mais que uma estratégia discursiva intencional, ou um processo de identificação, tal apropriação parece indicar a experiência subjetiva fragmentada de que esses sujeitos muitas vezes demonstram ter. Trata-se de um aspecto que pode ser de grande relevância para futuros estudos, capazes de remeter tais características não apenas às propriedades acústicas da voz, mas também à sua função comunicativa, inserida no campo das interações sociais. Nesse sentido, é preocupante que uma caracterização normativa da voz seja utilizada para a identificação precoce de casos de autismo, tal como proposto por Santos et al. (2013). Apesar de o algoritmo criado por esses pesquisadores supostamente realizar tal discriminação na idade de um ano e meio com uma eficácia de $97 \%$, não se pode minimizar os riscos de proceder uma avaliação desse porte baseada exclusivamente em uma resposta sonora, desvinculada de seu contexto.

Em um nível intersubjetivo, a oficina de música gera possibilidades de imitação, sincronização e coordenação de movimentos, facilitando a interação social entre seus participantes e a construção de uma experiência compartilhada. A natureza interativa das diferentes atividades indica que as mesmas incidem na qualidade do laço social, produzindo situações de ajustes mútuos de intenção, atenção e afeto, intercâmbio de sinais expressivos e de orientação mental, troca de turnos e compartilhamento de um pulso externo. Os jogos de alternância e de roda tiveram um papel de destaque nesse sentido, oferecendo uma estrutura temporal na qual elementos expressivos podiam ser ordenados, favorecendo a organização psíquica. Ressalta-se, no entanto, que esses eventos intersubjetivos podem não apresentar as mesmas qualidades esperadas para crianças com um desenvolvimento típico - tais como frequência, diversidade e conteúdo simbólico -, o que pode contribuir para a realização de um diagnóstico diferencial do autismo.

Com relação ao movimento corporal, as coreografias incidem percepção da música no corpo e no processo de construção da imagem corporal, o que possivelmente explica o incremento da fluidez dos gestos expressivos e da coordenação de movimentos corporais, as quais demonstraram ser algo problemático para algumas crianças. Em parte das coreografias que executamos, verificou-se uma dificuldade momentânea em acompanhar os movimentos dos demais, imitando-os de maneira equivocada, em um tempo diferido ou simplesmente não realizando-os. No transcurso do tratamento, um desenvolvimento desse aspecto pôde ser identificado, com uma melhora da qualidade dos movimentos, em termos de sincronia, coordenação e ajuste da velocidade, direção e intensidade. 
Uma terceira via de compreensão dos efeitos terapêuticos da música se encontra em um nível sociocultural, essencialmente porque ela inclui o sujeito na ordem das produções estéticas do seu grupo social. Não é possível minimizar a permeabilidade das crianças às músicas e canções transmitidas pelos meios de comunicação, e suas performances podem apresentar uma grande fidelidade ao original, mesmo quando o terapeuta se engana na recriação de uma canção. A música contribui, portanto, para a constituição de um ser cultural, mas não apenas no sentido de um aprendizado de uma tradição e de seus objetos e práticas simbólicas particulares. Mais do que isso, pelo menos no campo do autismo, importa o próprio fato da determinação social do sentido, e o modo como ela ocorre. Vivido cotidianamente com temor, esse processo é experimentado nas sessões de uma maneira que não é invasiva ou absoluta. Mais que organizado, o encontro com a alteridade na oficina de música é um encontro seguro.

Nessa perspectiva, o caráter lúdico da experiência musical é reforçado pela variedade de formas de brincadeiras e jogos, com níveis igualmente variados de exigências e entretenimento. São situações em que as crianças expõem suas frustrações e impossibilidades diante das demandas do Outro, por exemplo, quando uma delas não participa do jogo de apresentação dos nomes na primeira sessão. Mas são também momentos nos quais elas se descobrem fazendo algo novo e inusitado, nos quais podem surpreender a si mesmas, como quando essa mesma participante se vê envolvida pelo grupo e se diverte enquanto fazemos outra versão desse jogo de apresentação.

Certamente, uma das dinâmicas que produziram engajamentos sociais mais intensos e interativos foi a construção em grupo de narrativas com as ideias trazidas pelas crianças, favorecendo a sua apropriação dos elementos próprios da cultura, no sentido de uma "narrativa de si”. Nesse sentido, a oficina serviu para que eles contassem a sua história e mostrassem que podem atravessar momentos difíceis e realizar coisas importantes, assim como os personagens que interpretam. As variações de intensidade que encadeiam os elementos da sequência narrativa envolvem as crianças nessas experiência, absorvendo a sua atenção e integrando-as nas histórias, o que pode ser uma justificativa da sua eficácia simbólica.

$\mathrm{Na}$ construção de uma narrativa, esses elementos podiam ser propriamente musicais como uma célula rítmica, uma vocalização, uma canção, a imitação de um som - ou extramusicais - um personagem, um desenho, uma história, etc. A ordenação desses elementos em uma estrutura musical pode ser pensada nas dimensões: temática, pelo encadeamento com outras ideias ou o desenvolvimento das ideias iniciais; social, pela coordenação de movimentos com 
os pares e a inclusão dos demais membros na estrutura, criando uma alternância entre as partes de cada um; temporal, pela ordenação de elementos em uma série, com relações de causalidade, antecipações de movimentos e expectativas fundadas na dinâmica de tensão-resolução; espacial, pela distribuição e movimentação dos participantes de acordo com as características das músicas e canções; e corporal, pelos movimentos coordenados e rítmicos de todo o corpo ou suas partes. A inclusão desses elementos no interior de uma estrutura narrativa pode ser de grande valor no tratamento oferecido a essas crianças, se considerarmos a hipótese de que a experiência de encadeamento e continuidade desses elementos pode representar algum tipo de ordenação psíquica dessas categorias.

Outrossim, a música pareceu ter um efeito mais eficiente que as ordens, pedidos e reprimendas verbais na contenção de movimentos agitados e comportamentos agressivos. Isso ocorre porque a sensibilidade à música sustentaria uma estrutura de comunicação cuja ordem pode ser mantida pelas crianças com mais facilidade. Assim como nos demais compromissos que elas devem estabelecer com os demais, uma ação qualquer se relaciona a uma série de regras e normas existentes. Porém, no equilíbrio dinâmico dos sons e movimentos, a negociação do sentido de cada coisa pode ser facilmente remetida à construção coletiva. Ao manter o grupo coeso em torno à performance de uma canção ou improvisação, era possível simplesmente ignorar algumas insistências - que eventualmente deixavam de ser manifestadas, mesmo que temporariamente - ou até mesmo incluí-las na estrutura da música ou da brincadeira, incluindo-as em eventos de interação social. Obviamente, o resultado das transgressões não pode ser ignorado, e a música não fica melhor, como é lembrado por um dos participantes, sem que seja necessário apontar os limites e as normas, ou lançar mão de um padrão estético preestabelecido. É aí que uma intervenção no fluxo do musicar pode ser eficaz, cobrando das crianças uma adaptação aos movimentos e gestos no tempo.

A partir da AP3, os efeitos terapêuticos registrados podem ser resumidos em seus quatro eixos. Com relação ao brincar e a fantasia, as atividades da oficina incidem diretamente nessas funções, aumentando a sua fluidez e complexidade, ampliando as possibilidades de produção imaginária e a construção de narrativas. Os excessos que marcavam a brincadeira de William, frequentemente na repetição de cenas como correr pela sala, jogar objetos para o alto ou gritar, foram objeto de diversas intervenções, mas suas diversificadas fantasias formaram um elemento importante na condução do seu tratamento. Ao contrário da produção imaginária de William, Mathias inicialmente apresentou uma inibição no nível da fantasia, e apesar de que era 
raro vê-lo brincando com as outras crianças, ao longo das sessões foi possível estimular um engajamento mais lúdico com os demais. Já as brincadeiras de Pablo, se bem indicaram uma intensa capacidade de faz de conta, não nos permitiram interrogar seu limite entre a fantasia e o real. O que mais nos preocupava era a emergência de angústias e medos nessas situações. Diferentemente de William, em cujas brincadeiras pudemos identificar o medo associado ao risco e ao perigo, como na "Música assustadora", no caso de Pablo o medo era comumente representado por um objeto, uma aranha, um bicho, um monstro, o que pode ter favorecido um desenvolvimento dessas fantasias no episódio do jacaré. Também chamam a atenção as condutas imitativas presentes nas brincadeiras de Pablo nas sessões da oficina, o que nos leva a crer que acompanhamos um processo de constituição de um repertório singular próprio. Por sua vez, quando os atendimentos começaram, Camila mostrou um grave comprometimento da fantasia, fosse pela limitação da produção imaginária e do engajamento narrativo, ou pelo uso mecânico dos objetos. Ao longo das sessões, pudemos acompanhar como o brincar - que parecia algo restrito à concretude dos materiais - e as produções - como as camadas de papel e cola, que denotavam uma pobreza simbólica - adquiriam outros significados, permitindo que ela participasse da encenação coletiva de personagens e de alguma forma interagisse e se comunicasse com os demais.

Com relação à imagem corporal, as atividades da oficina incidiram sobre as discrepâncias motoras e problemas no movimento e na postura, nos casos de Mathias e Pablo. Para este últi mo, a eliminação dos sintomas relativos à evacuação certamente terá um forte impacto em seu desenvolvimento. $\mathrm{O}$ mesmo pode ser dito para a postura em $\mathrm{W}$ do primeiro, bem como o desenvolvimento de sua expressão gestual em termos de simetria e sincronia com os movimentos do outro. Já para Camila, o mais complicado foi intervir sobre a dificuldade de separar-se de sua mãe, porém os movimentos de construção de uma imagem corporal a partir dos seus contornos parecem ter sido o marco dessa etapa. Destaca-se ainda sua progressiva aceitação ao contato do outro. Com relação a William, os maiores avanços se deram com relação aos momentos de agitação, a dificuldade em manter-se quieto e a coordenação e controle dos movimentos. Espera-se que, de algum modo, as atividades tenham favorecido a unidade de um corpo que muitas vezes parecia ser experimentado de forma fragmentada.

No que se refere às formações da lei, destaca-se o trabalho com William, que diversas vezes demonstrou a ausência de uma instância interiorizada de interdição, ignorando as tentativas dos adultos de impor-lhe qualquer tipo de limite. Nesse sentido, pode-se dizer que houve 
algum avanço com relação à dificuldade de aceitar e manter as regras, mesmo quando elas afetavam aspectos nos quais ele era mais intransigente, como a troca de instrumentos. Nesse sentido, enfatiza-se as regra de tocar como forma eficiente de intervenção. A posição diante da lei também pode ser pensada no tratamento de Mathias sob a forma da marcação das durações e finais das atividades, que foi trabalhada extensivamente, com resultados ainda incertos.

Tendo em consideração a posição na linguagem, uma melhora significativa pode ser verificada no caso de Pablo, já que no início do tratamento sua expressão oral era retraída, confu sa e limitada. Foi preciso encontrarmos uma voz que realmente saísse "para fora", para que ele pudesse encontrar um outro lugar de onde enunciar a si mesmo, e aproximar-se de seus amigos. O comprometimento de Camila no domínio da linguagem era severo, com um fala reduzida a sons vocais e poucas palavras. As palavras tampouco ofereciam uma possibilidade de tranquilizá-la frente a suas angustias. No entanto, com o avanço do tratamento, pode-se verificar variações em sua posição na linguagem, tanto pela incorporação de novas palavras quanto por interações não-verbais complexas e ordenadas com os demais, o que favoreceu a sua integração ao grupo. No caso de Mathias, o grande destaque foi o uso das codas para ocupar um lugar de enunciação frente ao grupo, Ao mesmo tempo, verificou-se poucos avanços em questões como os discursos confusos, desconexos e desarticulados, assim como o uso do nome para referir-se a si mesmo e ocorrências de ecolalia.

Com relação a William, a linguagem foi um dos aspectos em que avanços foram verificados. De fato, as ocorrências de incoerências discursivas, reproduções de falas da televisão e neologismos por aglutinação com o tempo se tornaram menos e menos frequentes. $\mathrm{O}$ mesmo pode-se dizer de sua dificuldade de exprimir um pedido por uma canção ou atividade. Ao longo do tratamento, suas falas foram se tornando mais e mais próprias, a ponto de ele progressivamente enunciar seus desejos e ansiedades. $\mathrm{O}$ que pareceria ser da ordem das produções do outro permaneceu residualmente em sua voz, que muitas vezes assumia uma qualidade expressiva nitidamente distinta do usual.

Retomando nossa proposta inicial, a hipótese de que a música se articula de forma direta a processos de constituição da subjetividade porque integra o psiquismo sob a forma de uma identidade sonora foi parcialmente comprovada, tendo em vista os diversos processos de subjetivação acompanhados ao longo da parte empírica. Por outro lado, a noção teórica de que esses processos se orientam em torno do conceito de identidade não foi sustentada pela presente pesquisa. Apesar de diversas situações sugerirem a sua ação, não foi possível verificá-la através 
de indicadores dos efeitos que ela provoca na dinâmica da musicalidade comunicativa. Mais importante que isso, os movimentos de constituição subjetiva mais importantes que verificamos na parte empírica poderiam ser traduzidos como processos de identificação, e não de expressão de identidades.

Quando analisamos o modo como soluções a problemas de constituição da subjetividade são criadas nas sessões da oficina de música, dois princípios musicais terapêuticos fundamentais podem ser identificados. Primeiramente, os processos de expressão da identidade e de identificação parecem exercer papéis assimétricos na dinâmica do dispositivo. As ações expressivas, de uma maneira geral, não tiveram um fim em si, sendo usadas na sustentação de ações interativas de comunicação e de reconstrução do sentido de si e do mundo. Em segundo lugar, a música constitui uma modalidade de tratamento do Outro, possibilitando intervenções orientadas não aos indivíduos em si, mas a todo o campo simbólico de determinação do sentido.

Este estudo revela, portanto, e para além das dificuldades no relacionamento com o outro, uma série de habilidades sociais associadas ao autismo, e que as mesmas influenciam os processos terapêuticos em curso no tratamento. Como vimos no caso de Camila, a percepção e compreensão das interações sociais é problematizada quando se utilizam ferramentas de análise e descrição mais robustas que a simples observação. Esse resultado corrobora estudos que demonstram que uma parcela da sociabilidade é mantida nas crianças que desenvolvem o autismo, com diversas implicações para as pesquisas atuais sobre o tema. Primeiramente, ele reforça a ideia de que o reconhecimento precoce do autismo em bebês requer uma sensibilidade aguda de profissionais e protocolos de detecção com relação aos aspectos sociais, tendo em vis ta as diversas nuances das interações comunicativas. A análise dos estudos de caso apresentados aqui sugere que uma atenção maior deve ser dada à qualidade dessas interações, sobretudo se ela sustenta ou não uma experiência compartilhada, dado que essa característica pode indicar entraves no estabelecimento de relações com o outro. Em segundo lugar, esses mesmos as pectos podem ser considerados na clínica do autismo em seu sentido amplo, já que os eventos interativos serviram de base para a formação de laços sociais que subjazem a qualquer ação terapêutica. A musicalidade, cuja relação com a voz e a canção é uma área que ainda deve ser investigada mais aprofundadamente, parece ocupar um lugar de destaque nesse processo, tendo em vista sua relevância na comunicação, mesmo nos casos em que está severamente afetada. Por fim, indica que os processos de engajamento e coordenação nos motivos do outro, e não apenas o reconhecimento de seus estados mentais, constituem o aspecto central das dificulda- 
des experimentadas por sujeitos com autismo, mas também das habilidades que todavia podem ser desenvolvidas.

Isso significaria que, para aquelas crianças, as atividades permitiram experimentar de outra maneira seus próprios afetos e ideias, o tempo, o espaço, seu corpo e suas relações com os outros, o que poderia ser expandido para um registro mais amplo de suas vidas cotidianas. Ao longo dos grupos terapêuticos, elas enfrentaram uma variedade de situações nas quais precisaram pôr à prova seus medos, impotências e inseguranças, mas também tiveram a oportunidade de afirmar seus desejos e encontrar modos possíveis para compartilhar sua experiência com os demais. Os adultos muitas vezes estão a cargo de apresentar soluções criativas para os problemas que se apresentam na medida em que as crianças interagem, brincam e participam das atividades propostas. Isso possivelmente as fortalece para suportar situações que antes seriam enfrentadas com ansiedade ou dificuldade, mas nas quais elas podem agora empregar tudo aquilo que aprenderam e se transformou durante as sessões.

Em suma, a experiência musical é terapêutica quando oferece alguma forma de asilo (DENORA, 2013), uma

pausa da angústia e um lugar e um tempo em que é possível florescer. Por "florescer" entendo a capacidade de sentir no fluxo das coisas, de ser capaz de sentir-se criativo e envolver-se em brincadeiras criativas, desfrutar de um sentimento de validação ou conexão com os outros, de sentir prazer, talvez para notar a ausência ou a redução temporária da dor (p. 1).

Devido a esse potencial, a música vem sendo usada por diversos grupos sociais, em diferentes localizações históricas e geográficas para "resguardar certos tipos de ordem em seu mundo, e também criar novos tipos de ordem nele" (SEEGER, 1987, p. 128). Cada performance musical reestabelece as relações entre os elementos que constituem o universo criado pelos seres humanos e no qual as suas vidas se desenrolam. Em cada uma dessas ocasiões, eles não apenas revelam suas identidades, como também fundam novas maneiras de perceber e ser percebido pelos demais. Cantar, saltar e dançar não são apenas formas de expressar uma realidade, mas modos para operar uma metamorfose do mundo e de si. A música existe, desse modo, como uma tecnologia estética (DENORA, 2000), usada na construção conjunta de relacionamentos e experiências compartilhadas, no estabelecimento de oportunidades para conexão empática e formas expressivas de comunicação, como "um recurso para a constituição contínua de [selfs] e seus estados sociais emocionais, psicológicos e fisiológicos” (p. 47).

É esse, possivelmente, o núcleo responsável pelos usos da música com fins terapêuticos. Como afirma Trevarthen (1999), a música é terapêutica "porque ela afina os esforços essenciais 
que a mente faz em regular o corpo, tanto em seus processos internos quanto em seus engajamentos propositais com os objetos do mundo e com outras pessoas" (p. 8). Desse modo, o trabalho clínico com a música e as canções para crianças com autismo demonstrou ser menos expressivo que criativo. Trata-se da invenção de soluções aos problemas de constituição da subjetividade que surgiram na trajetória do seu desenvolvimento, sobretudo no que tange a relação com a alteridade.

Logo, para além do aporte metodológico e teórico, as principais contribuições da pesquisa estão em sua dimensão clínica. Ressalta-se que, em função de seus efeitos terapêuticos, a música deveria ser incluída nos sistemas de atenção aos problemas de desenvolvimento infantil. Nossos resultados indicam que o grupo terapêutico, que inclua indivíduos com diferentes graus de desenvolvimento e comprometimento funcional, é um dispositivo adequado para a realização de intervenções orientadas a essa população. O grupo deveria ser completado por um número suficiente de adultos, com ou sem formação musical, preferentemente coordenados por um psicólogo. Recomenda-se que a oficina de música seja realizada simultaneamente com outra atividade, ou que os participantes tenham acesso a um espaço em que possam permanecer sozinhos, se necessário, e que sua circulação seja permitida entre esses ambientes. A utilização de instrumentos variados - porém com uma baixa potência sonora, e distribuídos em pouca quantidade a cada sessão - mostrou ser significativa para a realização dos procedimentos, que devem incluir, além da recriação de canções, jogos musicais e momentos de improvisação. Por fim, as reuniões de discussão - se possível com a presença de outros profissionais que trabalham com os participantes -, a produção de relatos periódicos e registros audiovisuais, a associação com um tratamento individual concomitante, assim como o uso uma canção de abertura e encerramento e de estratégias para que as atividades musicais estejam disponíveis mesmo quando as sessões se suspendam - como nas férias escolares -, são todos elementos que podem colaborar para a incidência da oficina de música no tratamento dessas crianças.

Sugere-se também que uma ferramenta diagnóstica pode ser desenvolvida a partir desta investigação, utilizando os aspectos da prática musical que se mostraram problemáticos, tais como a interação musical, a flexibilidade narrativa, a coordenação de gestos coreográficos, as modulações da voz, etc. Caso confirmados em estudos transversais, tais elementos poderiam ser eventualmente aplicados em protocolos de detecção do autismo. Além disso, as canções podem ser pensadas como um suporte paraclínico no tratamento do autismo, pois podem ser utilizadas nos diversos contextos institucionais em que essas crianças circulam. Apesar de poder 
ser aprimorada com especializações técnicas e recursos materiais adequados, a música pode ser uma ferramenta bastante acessível, tanto aos profissionais ligados ao seu tratamento e escolarização, quanto aos pais e familiares. A canção, por sua vez, pode ser incorporada a outras técnicas terapêuticas e educativas, contribuindo em outros contextos e abordagens. É justamente a prática de cantar com e para essas crianças que pode ser benéfica para elas.

Por último, uma contribuição pode ser dada à compreensão das relações entre música e subjetividade, de um modo geral. No presente trabalho, a questão que se oferece de entrada a esse campo é a aplicação clínica da música: como, por que e quando a música apresenta efeitos terapêuticos? Nossa conclusão indica que a música é um ingrediente ativo nesse processo, cujo resultado é um movimento de transformação do funcionamento psíquico. Para DeNora (2013) e Trevarthen e Malloch (2000), a característica da música que explica suas propriedades terapêuticas é a sua capacidade de criar condições para o bem-estar emocional e cognitivo, e que, nesse contexto facilitador, o indivíduo seria capaz de retomar as funções comprometidas ou afetadas pela doença. Apesar de as sessões na oficina de música apoiarem essa ideia, tendo em vista como as atividades eram uma evidente fonte de prazer e alegria para as crianças, elas também indicam um laço mais profundo e radical entre a música e processos de constituição do sujeito psíquico. $\mathrm{Na}$ verdade, os efeitos da música não são apenas secundários, no sentido de que ela promoveria um ambiente onde transformações poderiam ocorrer. Essas mudanças ocorrem na própria ação musical, e podem ser expressas em termos musicais. A intensidade da experiência musical sugere que ela está envolvida diretamente na operação desses mecanismos.

Essa discussão pode ser compreendida em um debate ainda maior, sobre os efeitos - não somente terapêuticos - que a música exerce sobre o ser humano. Sem limitar-se à psicologia moderna, esse problema vem sendo alvo de preocupação há séculos. Já na Grécia antiga, como relata Platão (2006), a música era considerada uma atividade intimamente vinculada à formação moral dos jovens. Por esse motivo, os modos mixolídio, sintonolídio, jônico e lídio deveriam ser banidos do Estado ideal, os primeiros por serem excessivamente lamentosos, os outros por serem efeminados e moles. Harpas e trígonos estariam também excluídos dessa proposta de sociedade para que os jovens pudessem, por meio da música, aprender a lei e as medidas. Essa noção avançou na história da filosofia, sendo discutida por Aristóteles (1985) e Boécio (1989), chegando até a época Renascentista sob a forma da doutrina barroca dos afetos.

A partir daí, os efeitos da música progressivamente se tornam um objeto de estudo adotado pela ciência. Na concepção de DeNora (2003), a música não atravessou incólume esse 
percurso de abstração e sujeição aos métodos e teorias. Como consequência, seu estatuto no pensamento, como ela enfatiza, passou "de força animadora a um produto inanimado (um objeto a ser explicado)” (p. 3). Um dos indícios dessa mudança é que a música passa a ser pensada como a sobreposição de dois planos distintos - o dos sons e o dos comportamentos -, sendo esse o dilema de uma Antropologia da Música, tal como enfatizado por Alan Merriam (1964), um dos pioneiros da Etnomusicologia como campo destacado das Ciências Humanas. Sua proposta original foi a de estudar a música na cultura, pensando a primeira como parte de um todo orgânico, que seria a segunda.

Trata-se de um nível de estudo da música que pode ser abordado de um modo enumerativo (NETTL, 1983), através de uma perspectiva histórica, etnográfica e musicológica, em função dos papéis e funções do comportamento musical. Em contraste, outros autores, como Blacking (1995) e Seeger (1987) - e até mesmo o próprio Merriam (1977), em um trabalho posterior -, buscaram um nível de análise distinto, estudando a música como cultura, o que implicaria a tomada de uma teoria sobre a natureza da cultura a ser aplicada à música. Esse estudo seria uma especialidade da antropologia, dado que requer uma visão de cultura como sistema com partes interligadas e interrelacionadas, cabendo à música acomodar as estruturas culturais, transparecendo em si os valores centrais da sociedade. Nessa perspectiva, a música é fonte geradora de cultura e estrutura (BLACKING, 1995), pois as performances musicais, mais que refletirem a realidade social, de fato ordenam a vida social e as categorias pelas quais o espaço, o tempo, o corpo e a identidade social são definidas, de modo que é a própria "cultura que poderia ser concebida como algo que acontece na música” (HIKIJI, 2006, p. 62).

Essa inversão do paradigma resultou na proposição de uma Antropologia Musical, disciplina cuja ênfase se dá no estudo da sociedade pela perspectiva da performance musical, substituindo o estudo da música como um produto cultural pelo estudo dos processos sociais com relação à música ou, nas palavras de Seeger (1987), o "estudo da música como uma abordagem para o estudo de processos sociais em geral" (p. 138), que devem ser pensados "como performances intencionais, 'estruturações', e soluções criativas dentro de um campo de padrões e dentro de certas situações históricas percebidas” (p. 140). Como define esse autor,

Uma antropologia da música olha para o modo pelo qual a música é parte da cultura e da vida social. Em contraste, uma antropologia musical olha para o modo pelo qual performances musicais criam muitos dos aspectos da cultura e da vida social. Em lugar de estudar a música na cultura (...), uma antropologia musical estuda a vida social como uma performance. Em lugar de assumir que há uma matriz social e cultural, preexistente e logicamente anterior, dentro da qual a música é executada, ela examina o modo pelo qual a música é parte da construção e interpretação mesma das relações e processos, sociais e conceituais, (...) esta incursão na antropologia musical dedica-se 
ao estabelecimento de aspectos da vida social como musical e enquanto criada e recriada por meio da performance (p. xiii- xiv).

Esse mesmo movimento epistemológico pode ser encontrado também na Sociologia da Música, ao menos desde a passagem do século XX, quando se estabeleceu uma discussão centrada na ideia de música como meio que reflete a estrutura social. Análogo à Antropologia, como declara DeNora (2003), as Ciências Sociais "deslocaram o seu interesse de o que a música causava para o que causava a música” (p. 2, grifos da autora). O papel da música nessa perspectiva é a de um estímulo, algo que pode ser aplicado para determinada função. Para reverter esse argumento, foi necessária uma perspectiva interpretativa que implicasse a passagem de um foco estático para outro mais dinâmico, um deslocamento dos objetos estéticos e seu conteúdo em direção às práticas culturais que se apropriam e utilizam esses materiais para produzir a vida social. É nesse sentido que podemos falar também de uma Sociologia Musical, cuja definição mais precisa, defende DeNora (2003), pode ser encontrada na obra de Adorno (1974, 1996, 2009).

Com efeito, na perspectiva adorniana, sublinha-se o vínculo entre estruturas estéticas e estilos de consciência, isto é, estilos históricos de cognição, hábitos, atitudes mentais e modos de perceber o mundo. Assim, os caminhos que a música pode, para melhor ou pior, transformar a consciência, justificam sua crítica à música ligeira, não apenas de um ponto de vista musicológico - em termos do desenvolvimento raso com relação ao ritmo, melodia, harmonia e orquestração -, mas também por ser uma prática cognitivamente pobre, que reduz a atenção e a capacidade de distinguir as diferenças. A grande questão da música popular, portanto, é que ela suprimiria a complexidade, a diversidade e a heterogeneidade da experiência musical, promovendo uma pseudo-individualização a partir de um ciclo de expectativas e gratificações que condicionam o inconsciente, um fenômeno que Adorno (1996) chamou de regressão da audição. Para DeNora (2003), assim como pode-se dizer que o paladar pode regredir se a alimentação se restringe a comida processada e refrigerante, o mesmo ocorre com a audição nessa situação. Encurtar os horizontes da consciência, incitar o desejo e depois canalizá-lo por rotas estereotípicas poderiam, portanto, ser considerados os efeitos psicoculturais da música popular nessa perspectiva.

A leitura adorniana apresenta uma justificativa psicológica mas seu foco é inteiramente social, voltando-se à relação entre mecanismos culturais e os processos sociais de objetificação e alienação. Não obstante, o que Adorno evidencia é que tais processos sociais não correspondem a um modo mecânico em que os aspectos formais da música inculcam modalidades de 
consciência, pois são uma atividade, uma forma de práxis. Daí decorre que as máquinas da indústria cultural e sua produção de mercadorias são insuficientes no esforço para que a razão se torne conformista e privada de sua atividade crítica e reflexiva. Esse processo só se completa quando o sujeito desenvolve um gosto pela certeza e pelo familiar, um hábito mental de totalizar o mundo, de tomar o todo pela parte. Curiosamente, alguns dos aspectos que Adorno mais critica na música popular, como a simplicidade de arranjos, a uniformidade rítmica e a previsibilidade, parecem ser exatamente os que caracterizam e tornam eficaz a sua aplicação com finalidades terapêuticas, como afirma Barcellos (2009), e é confirmado por esta pesquisa. De qualquer modo, isso não invalida a proposição de que a música é capaz de operar mudanças importantes na constituição subjetiva. É compreensível, portanto, a ênfase dada por Adorno (1974) à música da Schoenberg, por ela oferecer uma forma estética não-convencional, capaz de despertar ambiguidade e confusão, e com isso desafiar as formas cognitivas vigentes. Se o serialismo é capaz de incitar um modo de pensamento diferente, é porque a sua estruturação expressiva segue regras que são igualmente distintas daquelas às quais estamos acostumados, o que exige uma escuta e uma interpretação ativa por parte do ouvinte.

O que essa perspectiva sociológica reforça é que, assim como na Antropologia Musical, a música em ação é um material dinâmico de estruturação da realidade social. É nesse sentido, como afirma Simon Frith, que (1987), "a pergunta que deveríamos estar fazendo não é o que a música popular revelar sobre 'o povo', mas como é que ela o constrói” (p. 137). Aquilo que pode ser tratado no Outro é justamente essa imagem que é o efeito de uma analogia, como diz Cage (1990), já que

a performance de uma peça de música pode ser uma metáfora da sociedade, de como queremos que a sociedade seja. Embora não estamos agora vivendo em uma sociedade que consideramos boa, poderíamos fazer uma peça de música em que estaríamos dispostos a viver. Eu não quero dizer literalmente, quero dizer, metaforicamente. Você pode pensar na peça de música como uma representação de uma sociedade em que você estaria disposto a viver (p. 177-78).

Não sem razão, a música como adjetivo, e não como predicado, é ainda encontrada na palavra Musicoterapia. Como denota o original em inglês, music therapy traduz-se fielmente como terapia musical, no sentido que os pioneiros nesse campo, Nordorff e Robbins, descreviam sua prática: não como música na terapia (music in therapy), mas como terapia na música (therapy in music). Para Ansdell (1995), era "a própria música que alcançava a criança diretamente e que formava a base do encontro entre as duas pessoas. Isso poderia então se expandir para um diálogo musical que poderia formar a base de uma relação terapêutica a longo prazo" 
(p. 4-5). Se a música é capaz de abrir um canal de diálogo mesmo nos casos em que isso era mais difícil, é porque ela interage com as instâncias mais fundamentais do psiquismo, onde a subjetividade pode se reorganizar e criar outras formas de funcionamento. Nessa linha, se a musicoterapia é clinicamente eficaz, é porque ela, como ressaltam Trevarthen et al. (1998) “oferece um contexto para construir um sentido de 'si-em-relação"” (p. 175).

A proposta de transpor, no campo da Psicologia, essa mesma passagem de uma ciência da música para uma ciência musical já havia sido apresentada anteriormente (AVILA, 2009). Naquele momento, importava a adoção pela Psicologia da Música das noções de música e subjetividade como duas entidades distintas e separadas, onde a primeira é vista como estímulo ou resposta produzida pelo indivíduo. Essa perspectiva foi exemplificada pela obra de Helmholtz (1954), pioneiro no estudo das sensações sonoras enquanto base de uma teoria da música. Ao convergir conhecimentos da física ondulatória, da fisiologia da audição e da anatomia do ouvido e da voz, ele foi determinante em possibilitar um estudo psicológico do comportamento musical, como a percepção de consonâncias e dissonâncias. Mas, para a Psicologia, provavelmente porque sua estratégia metodológica era justamente a objetificação de uma prática subjetivante, sua pesquisa não pôde avançar para além de uma teoria psicoacústica baseada nos aspectos experimentais da organização tonal elementar.

Na perspectiva de uma Psicologia Musical, o sujeito, mais que produtor de fenômenos musicais, deveria considerado o resultado deles, em um processo de construção musical da subjetividade. Como vimos nesta pesquisa, a música apresenta uma capacidade extraordinária de afetar as categorias mais básicas que definem nossa experiência da realidade. Isso indica que não há um sujeito a priori que aprende e canta as músicas de um grupo. Somente assim podemos compreender a afirmação enigmática de Blacking (1985) de que existe "um sentido no qual um compositor é composto e um pianista é tocado” (p. 53). Não existimos antes da música, mas sim simultaneamente a ela, somos efeitos da música.

Como definimos na discussão sobre a função psíquica da voz, isso ocorre porque a música participa do processo de constituição e produção da subjetividade a partir de uma espécie de memória, a lembrança de uma alteridade fundamental antes esquecida. Como mostra DidierWeill (1997a), é justamente esse o efeito de estranhamento, de percepção de algo que é ao mesmo tempo familiar e alheio.

O que ocorre com você quando escuta uma música que toca? Através de que magia esta mensagem tem o poder de induzir em você uma metamorfose? Num primeiro momento, você sente, enquanto ouvinte, que está escutando a música. Mas na medida em que é 'tocado', como se diz, você descobrirá que de fato não é você que escuta, 
mas que é a música que o escuta, que escuta uma presença de cuja existência você se esqueceu e que, pelo fato de ser escutada, passa a reviver e a lhe ser dada (p. 198).

Portanto, a música não é apenas moldada pelas forças psíquicas do sujeito, ela de fato é um meio dinâmico da vida psíquica, algo no qual a mente acontece. Como qualquer forma de arte, ela lida com problemas e conceitos, e "responde a problemas sobre regimes de determinação e sobre possibilidades de reorientação de categorias como identidade, diferença, relação, unidade, entre outras" (SAFATLE, 2006, p. 169). E tais soluções são aproveitadas nos problemas que enfrentamos no processo de viver e desenvolver-se. Isso se deve ao fato de que seus aspectos formais tanto incidem sobre aquilo que na mente permanece informe, quanto levam o que estava cristalizado a transformar-se. A música, portanto, não precisa ser vista como algo separado da subjetividade, mas algo através do qual as funções psíquicas se constituem e operam, de uma maneira específica, correspondente às suas qualidades expressivas. Logo, assim como a forma e a experiência musical estão diretamente ligados a processos de constituição subjetiva, no horizonte em que se entrelaçam música e sujeito, encontramos o paralelismo entre a formalização estética e os processos de subjetivação, entre a gênese da obra de arte e a gênese do sujeito. Assim sendo, é realmente possível ser "o grande experimentador de si mesmo" (NIETZSCHE, 1987, p. 136). Pois, já que “o eu não nos é dado", como assinala Foucault, "há apenas uma consequência prática: temos que nos criar a nós mesmos como uma obra de arte" (apud RABINOW; DREYFUS, 1995, p. 262). Nesse sentido, a terapia representa uma forma de composição musical da realidade, empregando a música como uma tecnologia estética de si (DENORA, 1999). E quando essa potência se expressa de um modo espontâneo e intuitivo, como ocorre com a criança, essa dimensão criativa assume a sua plenitude.

As crianças apenas 'se transformam' em gestos sonoros guiadas pela inteireza de seu modo de ser e de se organizar continuamente (...) uma espécie de musicriança: as crianças transmutadas em sons" (BRITO, 2007, p. 80, grifos da autora).

Podemos, a partir dessa proposta, repensar uma série de aspectos da relação entre a música e o sujeito. A questão da expressão é uma delas, na medida em que a música é tradicionalmente pensada como facilitadora de movimentos expressivos porque ofereceria uma inscrição simbólica que daria forma ao afeto. De fato, como lembra Kauffman (1998), a psicologia deve ocupar-se das "relações da música com os sentimentos, da música com a linguagem e, para encerrar, da música com a representação, que repousa em uma comunicação entre o compositor e o ouvinte" (p. 695). É certo também que a conduta expressiva é mediadora das instâncias objetivas e subjetivas, mas a expressão é também, como lembra Bruner (1986), o encapsulamento 
de uma experiência subjetiva, que não traduz ipsis litteris os seus conteúdos. Assim entendemos o rechaço de Stravinsky (1936) ao considerar a música, "basicamente impotente para exprimir o que quer que seja: um sentimento, uma atitude mental, um estado psicológico, um fenômeno da natureza, etc. [...] A [expressão] nunca foi uma propriedade inerente à música. É por isso que não é de forma alguma o propósito de sua existência” (p. 53).

Mais que expressar, o valor da música é o de produzir e transformar, assim como a narrativa, que ao mesmo tempo em que é contada, altera a história de vida do sujeito (BRUNER, 1991, 2004). É justamente nesse sentido que, quando perguntado sobre os motivos que o levavam a compor, John Cage respondeu: "O que eu faço não é para me expressar, mas para mudar a mim mesmo" (apud CAMPOS, 1998, p. 147). E para que o conceito de expressão possa ser compreendido nessa perspectiva, é preciso que aquilo que é expressado não se separe do ato que o produz, nem deixe de produzir ato, no sentido que Lacan (1986) conferiu ao conceito de palavra plena: aquela pela qual o sujeito "se encontra, depois, outro que não o que era antes" (p. 129).

Como consequência não é possível escutar na música uma verdade sobre o sujeito, qualquer coisa que pudesse expressar aquilo ao qual ele é idêntico. O que ela pode sim é indicar os parâmetros formais envolvidos no modo como o sujeito reinventa a si mesmo. A arte, como prática expressiva, é um meio privilegiado para que esse processo ocorra em seu sentido mais forte, e como nota Schlözer (apud KAUFFMAN, 1998),

O que caracteriza essencialmente o artista (...) é a produção de uma coisa cuja geração, cujo próprio processo de geração, modifica seu autor, permitindo-lhe transcender-se, ser, ao mesmo tempo, plenamente ele mesmo e um outro. A atividade criadora consistiria, sempre segundo esse autor, não unicamente em gerar um sistema orgânico, mas ainda em produzir conjuntamente o próprio autor desse sistema, o que nele se acha imediatamente presente (p. 700).

Ainda com relação à expressão, este trabalho deu ênfase à noção de identidade sonora, a qual foi pensada como uma assinatura sonora pessoal e inconsciente que, quando expressada, produziria efeitos terapêuticos. Essa ideia encontra apoio em práticas clínicas que extrapolam o campo da música, como mostra o documentário “Um encontro com Lacan” (MILLER, 2011), no qual um analisando comenta que

Lacan se ocupava, sobretudo, de ouvir aquele que lhe falava. Lacan sabia as palavras que importavam para alguém e sabia usá-las com conhecimento. Era impressionante! Quando ele extraía, daquilo que dizíamos, uma palavra, uma frase, uma preocupação, dizia a cada um: "Essa é a sua música. Isso é você. Aí está".

Mas se a expressão da identidade possui uma potência clínica é porque ela também é, 
mais que a comunicação de algo que já preexiste, o registro de uma ação que se desenvolve no interior do funcionamento psíquico do indivíduo. Como ressalta Benenzon (2011), a identidade é um conglomerado de energias, em permanente movimento e com uma dinâmica particular, em uma "dinâmica nos caracteriza e nos diferencia e re-cria nossa personalidade e nossa forma de ser”. É nesse sentido que uma concepção dinâmica de identidade não exclui os movimentos dos quais ela resulta, ou seja, os processos de identificação. Essa ideia poderia ser empregada com uma finalidade clínica, fazendo da terapia a construção de relações, identidades e diferenças, como um processo de composição musical de si e do outro. Isso não deve limitar-se à utilização de materiais sonoros exclusivamente, já que se refere propriamente a mecanismos psíquicos gerais. No que tange à aplicação clínica da música, no entanto, há um fator específico a ser considerado: a importância de um ambiente musical como tratamento do Outro. Na clínica do autismo, a experiência musical permite a apresentação de um elemento cultural que é aceitável do ponto de vista da criança, e potencializador da emergência desse sujeito que muitas vezes está isolado, do ponto de vista do adulto. E o terapeuta, aproveitando a inclusão da criança nesse novo mundo possível, intervém para que ela mesma possa ser outra.

Com esse marco teórico, cabe pensar novamente os fatores atuantes na vinheta clínica apresentada na introdução. Não é possível saber se V. de fato conhecia ou gostava dos Beatles, ou até que tenha reconhecido a canção. Por outro lado, o mesmo não aplica a mim e Tiago, que certamente nutrimos uma grande admiração por essa banda, e que possivelmente tenhamos escutado e desfrutado de "Revolution" diversas vezes, em uma variedade de contextos e situações. Tomando aquela situação por um todo, ainda que não possamos localizar as canções dos Beatles, o blues e os afetos que ressoam na identidade sonora de V., eles certamente estavam presente na nossa, enquanto músicos, terapeutas e sujeitos, membros de um grupo social que tomou esses elementos de uma cultura estrangeira e os fez parte de seu próprio universo. É apenas compreendendo o seu significado para nós como dupla de coordenadores que podemos entender a fundo o que ocorre naquela cena. Porque "Revolution" era parte da nossa história e daquilo que nos constituiu como somos em uma infinidade de sentidos, que mediou nossas relações com a geração que nos precedeu, que esteve presente em nossa educação, tanto musical quanto de idiomas, um objeto no qual investimos nosso desejo e que usamos em nossos momentos de diversão e de ócio, mas também nos maus momentos, quando nos ajudou a fortalecer-nos e recuperar-nos.

O que então motivou esse comportamento tão incomum de V. poderia ter sido então a 
mera alegria pela entrada da voz em lugar da gaita, a surpresa pela passagem da improvisação para a canção, o conforto do retorno dos versos após um solo, a sensação de conexão e sentido entre modos expressivos distintos. E se é certo que esse não era um sentimento que afetasse exclusivamente a ele, mas que de fato nos envolvia a todos naquela situação terapêutica, foi também uma alegria que compartilhamos enquanto grupo musical, assim como poderia ter sido sentido por um grupo de instrumentistas em um ensaio ou uma apresentação, quando as partes da música se unem e transmitem uma sensação de continuidade e fluidez, de unidade e comunhão. Por um momento, como se tudo se encaixasse e tivéssemos formado um trio coeso, algo novo se tornou audível, e definitivamente deixamos de ser estrangeiros uns para os outros. $\mathrm{E}$ isso certamente deveria ser algo a ser comemorado, tanto por nós adultos quanto por $\mathrm{V}$.

Lembremos também que uma das características tradicionalmente associadas ao blues é a intensa manipulação emocional de músicos e ouvintes, baseada no uso do intervalo de quarta diminuta e da harmonia menor, orientada no sentido de uma emancipação catártica da tristeza. Nossa performance pode ter sido apenas mais uma repetição nessa evolução cultural que conduz o passado dos escravos expatriados ao futuro, atravessando-nos no caminho, mas que não por menos deixa de recuperar todos esses efeitos terapêuticos que são o seu legado para a história. E a reação de V. poderia, nessa linha, ser considerada também uma repetição das frenéticas reações que os Beatles foram os mestres em despertar, a famosa beatlemania.

Isso evidencia que a técnica da recriação de canções não é algo mecânico, como uma simples reprodução, mas um exercício verdadeiramente criativo. É evidente que a peça a ser recriada serve de apoio para a performance de terapeuta e/ou paciente, porém esse suporte põe em movimento todo um campo intersubjetivo no qual incidem diversas forças históricas e culturais para alcançar um determinado fim terapêutico. Portanto, a reação enérgica revela muito pouco ou quase nada sobre o que poderia existir antes daquele momento pois, como a vinheta encapsula em si, ela é o ápice de uma verdadeira "experiência", com todas as suas implicações vitalizadoras incluídas.

E se tal experiência é realmente terapêutica, o motivo reside no fato de que ela traz do silêncio algo que se torna audível, algo da ordem da diferença e da invenção de novas relações. Se a música pode incidir de modo tão intenso em nós e em nossa experiência do mundo, a clínica é o dispositivo no qual busca-se a abertura mais segura para aventurar-se nessa outra realidade, e descobrir nela o lugar e, que estamos.

Existe, de fato, um considerável valor terapêutico em permitir-se estar profundamente ciente de qualquer imagem ou som que possa surgir. Por um lado, isso traz à mente 
a maravilha de ver e ouvir como tal. Por outro lado, a profunda disposição a ouvir ou olhar em cima de qualquer coisa liberta a mente de preconceitos fixos de beleza, criando, por assim dizer, um espaço livre em que formas e relações completamente novas podem surgir (LIEBERMAN, 2016).

Evidentemente, o que se apresentou até aqui é uma teorização incompleta, cujo desenvolvimento não era objetivo deste trabalho. Indiretamente, no entanto, os resultados já avançam algumas das questões que poderiam ser abordadas sob essa perspectiva. Em um nível metodológico, os procedimentos de descrição e análise propostos podem ser de alguma valia no sentido de inverter o paradigma metodológico atual entre psicologia e música e, assim, orientar uma pesquisa híbrida, pertencente à psicologia quanto a seus conteúdos e à música quanto a seus métodos. Sem deixar de lado o papel que a alteridade desempenha nesse processo, acompanhamos Didier-Weill (1997b) quando afirma que "não hesitamos em declarar que uma reflexão teórica sobre a música é um dos caminhos possíveis para compreender a relação mais primordial do sujeito com o Outro" (p. 240). Talvez assim, entenderíamos como uma apreciação artística do tempo é capaz de reorganizar o campo simbólico e reordenar as categorias mais fundamentais da experiência. Essa deverá ser a ênfase de um estudo dos modos de subjetivação com relação à música: um problema tridimensional, ao mesmo tempo estético, social e psicológico.

Uma psicologia da música que acompanhe a evolução dessas perguntas, assim como vêm sendo trabalhadas em outros campos do conhecimento, poderia oferecer uma contribuição relevante para uma série de questionamentos. Se, de um lado, a psicologia já possui um histórico de interação com outras perspectivas das humanidades - demonstrando ser um campo flexível para a incorporação de teorias e métodos de outras disciplinas para a realização de seus fins -, por outro, tais perspectivas podem perfeitamente apropriar-se de concepções próprias à disciplina psicológica. Uma noção de sujeito distinta das de eu ou de agente poderia ser essa contribuição. Pois uma concepção de sujeito como instância psíquica inconsciente seria certamente útil a essas investigações, ampliando nossa compreensão sobre os fenômenos relacionados à música, sob a luz da constituição subjetiva. 


\section{REFERÊNCIAS}

ADORNO, T. W. Current of Music: Elements of a Radio Theory. Cambridge e Maiden: Polity Press, 2009.

. Filosofia da Nova Música. São Paulo: Perspectiva, 1974.

O Fetichismo na Música e a Regressão da Audição. In: Textos escolhidos. São Paulo: Nova Cultural, 1996. p. 65-108.

AGOSTINHO, Aurélio. De magistro liber. Milão: Mursia, 1993.

ALLIONE, C. La recherche des rythmes disparus. Cliniques méditerranéennes, v. 75, n. 1, p. 277-294, 2007.

ALTSHULER, I. A Psychiatrist's Experience with Music As a Therapeutic Agent. In: SCHULLIAN, D.; SCHOEN, M. (Orgs.). Music as Medicine. Nova Iorque: Henry Schuman, 1948. p. 270-271.

ALVAREZ, A.;REID, S. Introduction: Autism, personality, and the family. In: (Eds.). Autism and Personality: Findings from the Tavistock Autism Workshop. Londres e Nova Iorque: Routledge, 1999. p. 1-10.

ALVIN, J.; WARWICK, A. Music Therapy for the Autistic Child. Oxford: University Press, 1992.

ANSDELL, G. Music for Life: Aspects of Creative Music Therapy with Adult Clients. Londres: Jessica Kingsley, 1995.

ANZIEU, D. Le moipeau. Paris: Dunod, 1995.

ARISTÓTELES. Política. Brasília: Universidade de Brasília, 1985.

ASPERGER H. 'Autistic Psychopathy' in childhood. In: FRITH U. Autism and Asperger Syndrome. Cambridge: Cambridge University Press; 1992. p. 37-62. (Trabalho original publicado em 1944)

ASSOCIAÇÃO AMERICANA DE PSIQUIATRIA. Manual de diagnóstico e estatística de distúrbios mentais: DSM-IV. Lisboa: Climepsi, 2002.

. Diagnostic and Statistical Manual of Mental Disorders: Third Edition Revised (DSM-III-R), 1987. Disponível em: <http://dsm.psychiatryonline.org/data/PDFS/dsm-iiir.pdf>.

Diagnostic and Statistical Manual of Mental Disorders: Fifth Edition (DSM-V). Arlington, VA: American Psychiatric Association, 2013. 
AVILA, D. C. Das (Im)Possibilidades de uma Psicologia Musical. TransFormações em Psicologia, v. 2, p. 79-97, 2009.

Psicoanálisis y Música. In: VI Congreso Internacional de Salud Mental y Derechos Humanos, 2007, Buenos Aires. Trabajos $6^{\circ}$ Congreso. Buenos Aires: Asociación Madres de Plaza de Mayo, 2007.

Psicanálise e música: contribuições à clínica. In: 14º Simpósio internacional de iniciação científica. São Paulo: Universidade de São Paulo, 2006.

AZEVEDO, A. V. De la-land à lalangue: algumas questões de estilo. Colóquio de Encore: A letra e o saber fazer com lalíngua. São Paulo, 2014.

BACHELARD, G. A Epistemologia. Lisboa: Edições 70, 2001.

BAHR, D. M.; HAEFER, J. R. Song in Piman Curing. Ethnomusicology, v. 22, n.1, p. 89$122,1978$.

BAIO, J. Prevalence of Autism Spectrum Disorders - Autism and Developmental Disabilities Monitoring Network, 14 Sites, United States, 2008. Surveillance Summaries, v. 61, n. SS03, p. 1-19, 2012.

BALL, C. M. Music therapy for children with autistic spectrum disorder. Bazian Ltd, nov., 2004.

BARON-COHEN, S.; LESLIE, A.M.; FRITH, U. Does the autistic child have a 'theory of mind'? Cognition, v. 21, p. 37-46, 1985.

BARCELLOS, L. R. M. A música como metáfora em musicoterapia. Tese (Doutorado em Música) - Universidade Federal do Estado do Rio de Janeiro, Rio de Janeiro, 2009.

BATESON, G. Communication. In: MOKROS, H. B. (Ed.) Interaction \& Identity. Nova Jérsei: Transaction, 1996. p. 45-72.

. Steps to an ecology of mind. Nova Iorque: Ballantine Books, 1972.

Metalogue: why do Frenchmen?. In: VAN TUYL, M. (Ed.) Impulse: annual of contemporary dance. São Francisco: Impulse Productions, 1951.

BATESON, M. C. The epigenesis of conversational interaction: A personal account of research development. In: BULLOWA, M. (Ed.). Before Speech: The beginning of human communication. Londres: Cambridge University Press, 1979. p. 63-77.

BEEBE, B. Mother-infant research informs mother-infant treatment. Psychoanalytic Study of the Child, v. 60, p. 7-46, 2005.

et al. Systems Models in Development and Psychoanalysis: The Case of Vocal Rhythm Coordination and Attachment. Infant Mental Health Journal, v. 21, n. 1-2, p. 99-122, 
2000.

BEHLAU, M.; REHDER, M. I. Higiene vocal para o canto coral. Rio de Janeiro: Revinter, 1997.

BENENZON, R. O. El espiral de los ISos. Disponível em: <www.centrobenenzon.com.br/cmbb/pdf/el_espiral_de_los_isos.pdf>. Acesso em 17 ago. 2011.

Teoria da Musicoterapia. São Paulo: Summus, 1988.

. Manual de Musicoterapia. Rio de Janeiro: Enelivros, 1985.

BERGSTRØM-NIELSEN, C. Graphic Notation in Music Therapy: A Discussion of What to Notate in Graphic Notation, and How. Approaches: Music Therapy \& Special Music Education, v. 1, n. 2, p. 72-92, 2009.

BERLIOZ, H. Episode de la vie d'un artiste: Symphonie Fantastique en cinq parties. Paris: Conservatoire de Musique, 1830.

BERLYNE, D.E. Aesthetics and psychobiology. Nova Iorque: McGraw-Hill, 1971.

BERNARDINO, L. M. F. De que pathos se trata no autismo? II Congresso Internacional de Psicopatologia Fundamental, 2006.

BERNSTEIN, L. Leonard Bernstein's Young People's Concerts: with the New York Philharmonic. Kultur Video, 2004. 9 DVDs (1.500 min.). NTSC, son., color e p\&b. (Trabalho original publicado em 1961)

. The Unanswered Question: Six Talks at Harvard. Cambridge: Harvard University Press, 1976.

BIRDWHISTELL, R. L. Kinesics and context: essays on body motion communication. Philadelphia: University of Pennsylvania Press, 1970.

Body motion research and interviewing. Human Organization, v. 11, p. 37-38, 1952.

BLACKING, J. Music, culture \& experience: selected papers of John Blacking. Chicago: University of Chicago Press, 1995.

BLASCO, S. P. Introducción a la Musicoterapia. In: CONFEDERACIÓN ASPACE; FEDERACIÓN ESPAÑOLA DEL SÍNDROME DE DOWN; CONFEDERACIÓN AUTISMO ESPAÑA (Eds.). Musicoterapia 2002: Programa de Formação para Mediadores en Musicoterapia y Discapacidad. Madrid, 2002, p. 5-48.

BLEGER, J. O grupo como instituição e o grupo nas instituições. In: Temas de Psicologia: entrevista e grupos. São Paulo: Martins Fontes, 2007. p. 101-122. 
BLEULER, E. Dementia Praecox or the Group of Schizophrenias. Nova Iorque: International Universities, 1950. Trabalho original publicado em 1911.

BOÉCIO. Fundamentals of music. New Haven e Londres: Yale University Press, 1989.

BOERSMA, P.; WEENINK, D. Praat. doing phonetics by computer, version 5.3.19. Amsterdã: University of Amsterdam, 2012. Programa de computador. Disponível em <http://www.praat.org>.

BONNEH, Y. S. et al. Abnormal speech spectrum and increased pitch variability in young autistic children. Frontiers in Human Neuroscience, v. 4, p. 1-7, 2011.

BONNY, H.; SAVARY, L. M. Music and your mind: Listening with a new consciousness. Nova Iorque: Harper and Row, 1973.

BOSA, C.; CALLIAS, M. Autismo: breve revisão de diferentes abordagens. Psicol. Reflex. Crit., Porto Alegre, v. 13, n. 1, 2000.

BOYSSON-BARDIES, B. How language comes to child: From birth to two years. Massachussets: MIT Press, 1991.

BRANDALISE, A. Musicoterapia músico-centrada: Linda - 120 sessões. São Paulo: Apontamentos, 2001.

BRASIL. Linha de cuidado para a atenção às pessoas com Transtornos do Espectro do Autismo e suas famílias na Rede de Atenção Psicossocial do SUS. Brasília: Ministério da Saúde, 2013.

BRITO, T. A. Por uma educação musical do pensamento: novas estratégias de comunicação. Tese (Doutorado em Comunicação e Semiótica) - Pontifícia Universidade Católica, São Paulo, 2007.

BROWN, S. The "musilanguage" model of music evolution. In: ;WALLIN, N. L.; MERKER, B. (Eds.). The Origins of Music. Cambridge: MIT Press, 2000. p. 271-300.

BRUNER, E. M. Experience and Its Expressions. In: TURNER, V. W.; logy of Experience. Urbana e Chicago: University of Illinois, 1986. p. 3-32. The Anthropo-

BRUNER, J. S. Life as Narrative. Social Research. v. 71, n. 3, p. 691-710, 2004.

. The narrative construction of reality. Critical Inquiry, v. 18, n. 1, p. 1-21, 1991.

.; FELDMAN, C. Theories of mind and the problem of autism. In: BARONCOHEN, S.; TAGER-FLUSBERG, H.; COHEN, D. J. (Eds.). Understanding other minds: Perspectives from autism. Oxford: Oxford University Press, 1993.

BRUSCIA, K. E. Definindo musicoterapia. Rio de Janeiro: Enelivros, 2000. 
CAGE, J. I-VI. Cambridge: Harvard University Press, 1990.

CAMPBELL, P. S. Songs in Their Heads: Music and its Meaning in Children's Lives. Nova Iorque e Oxford: Oxford University Press, 1998.

CAMPOS, A. Música de invenção. São Paulo: Perspectiva, 1998.

CAPPS, L.; LOSH, M.; THURBER, C. “The frog ate a bug and made his mouth sad”: Narrative competence in children with autism. Journal of Abnormal Child Psychology, v. 28, p. 193-204, 2000.

CATÃO, I. O bebê nasce pela boca: voz, sujeito e clínica do autismo. São Paulo: Instituto Langage, 2009.

CHAVARRIAS, V. R. Intervención de musicoterapia en personas con autismo. In: CONFEDERACIÓN ASPACE; FEDERACIÓN ESPAÑOLA DEL SÍNDROME DE DOWN; CONFEDERACIÓN AUTISMO ESPAÑA (Eds.). Musicoterapia 2002: Programa de Formação para Mediadores en Musicoterapia y Discapacidad. Madrid, 2002. p. 147-155.

COHEN, D. J.; VOLKMAR, F. R. (Eds.). Handbook of Autism and Pervasive Developmental Disorders. Nova Iorque: Wiley, 1997.

COHN, J. F.; TRONICK, E. Specificity of Infants' Response to Mothers' Affective Behavior. J. Am. Acad. Child Adolesc. Psychiatry, v. 28, n. 2, p. 242-248, 1989.

CONDON, W. S. Multiple response to sound in dysfunctional children. Journal of autism and childhood schizophrenia, v. 5, n. 1, p. 37-56, 1975.

.; OGSTON, W. D. A segmentation of behavior. Journal of Psychiatric Research, v. 5, p. 221-235, 1967.

.; OGSTON, W. D. Sound Film Analysis of Normal and Pathological Behavior Patterns. Journal of Nervous \& Mental Disease. v. 143, n. 4, p. 338-347, 1966.

.; SANDER, L. W. Synchrony Demonstrated between Movements of the Neonate and Adult Speech. Child Development, v. 45, n. 2, p. 456-462, 1974.

DECASPER, A. J.; SPENCE. M. J. Prenatal Maternal Speech Infuences Newborn's Perception of Speech Sounds, Infant Behavior and Development, v. 9, p. 133-150, 1986.

DELALANDE, F. La musique est un jeu d'enfant. Paris: Institut National de L'Audiovisuel, 2003.

DENORA, T. Music Asylums: Wellbeing Through Music in Everyday Life. Surrey e Burlington. Ashgate, 2013

Music-in-Action: selected essays in sonic ecology. Surrey e Burlington: Ashgate, 
. Music in Everyday Life. Cambridge: Cambridge University Press 2004.

2003.

. After Adorno: Rethinking Music Sociology, Cambridge: Cambridge University Press,

Music as a technology of the self. Poetics, v. 27, p. 31-56, 1999.

DEPAPE, A.-M. R. et al. Use of prosody and information structure in high functioning adults with Autism in relation to language ability. Frontiers in Psychology, v. 3, p. 1-13, 2012.

DEWEY, J. Arte como experiência. São Paulo: Martins Fontes, 2012.

DIDIER-WEILL, A. Os três tempos da lei: o mandamento siderante, a injunção do supereu e a invocação musical. Rio de Janeiro: Jorge Zahar, 1997a.

. A Nota Azul: Freud, Lacan e a Arte. Rio de Janeiro: Contracapa, 1997b.

DISSANAYAKE, E. An Ethological View of Music and its Relevance to Music Therapy. Nordic Journal of Music Therapy, v. 10, n. 2, p. 159-175, 2001.

DOLAR, M. A voice and nothing more. Cambridge: Massachusetts Institute of Technology Press, 2006.

DREHER, S. C. A canção: um canal de expressão de conteúdos simbólicos e arquetípicos. Psicologia Argumento, Curitiba, v. 23 n. 42, p. 127-144, 2005.

Quando eu soltar a minha voz - A canção: um canal de expressão de conteúdos simbólicos e arquetípicos. Revista Brasileira De Musicoterapia, São Paulo, v. 10, n. 8, p. 127-143, 2006.

DUBOIS, T. A. An introduction to shamanism. Cambridge: Cambridge University Press, 2009.

DUPOUX, E.; MEHLER, J. Naître humain. Paris: Odile Jacob, 1990.

DURKHEIM, E. Representações individuais e representações sociais. In: . Sociologia e Filosofia. São Paulo: Ícone, 1994. p. 9-54.

EDGERTON, C. L. The effect of improvisational music therapy on the communicative behaviors of autistic children. Journal of Music Therapy, v. 31, n. 1, 1994.

FALK. D. Hominid brain evolution and the origin of music. In: WALLIN, N. L.; MERKER, B.; BROWN, S. (Eds.). The Origins of Music. Cambridge: MIT Press, 2000. p. 197-216.

FELD, S. Sound and Sentiment. Birds, Weeping, Poetics, and Song in Kaluli Expression. Philadelphia: University of Pennsylvania Press, 1982.

FERNALD, A. Four-month-old infants prefer to listen to motherese. Infant Behavior and 
Development, v. 8, n. 2, p. 181-195, 1985.

.; KUHL, P. Acoustic determinants of infant preference for motherese speech. Infant Behavior and Development, v. 10, n. 3, p. 279-293, 1987.

FORDHAM, J. Ornette Coleman obituary. In: The Guardian. Disponível em: <http://www.theguardian.com/music/2015/jun/11/ornette-coleman>. Acesso em 13 jun. 2015.

FOUCAULT, M. História da loucura: na Idade Clássica. São Paulo: Perspectiva, 2012.

FRAISSE P, OLERON G, PAILLARD J. Dynamogenic effects of music; experimental study. Annee Psychol., n. 53, v. 1, p. 1-34, 1953.

\section{FREEMAN,}

FREIRE, A. B.; BASTOS, A. Paradoxos em torno da clínica com crianças autistas e psicóticas: uma experiência com a "prática entre vários". Estilos clin., São Paulo, v. 9, n. 17, 2004.

FREUD, S. O Moisés de Michelangelo. In: . Edição Standard Brasileira das Obras psicológicas completas de Sigmund Freud: v. 13, Rio de Janeiro: Imago, 1996. p. 213-140. (Trabalho original publicado em 1914)

Recordar, repetir e elaborar: Novas recomendações sobre a técnica da Psicanálise. In: . Edição Standard Brasileira das Obras Completas de Sigmund Freud: v. 12. Rio de Janeiro: Imago, 1996. p. 193-207. (Trabalho original publicado em 1914)

Além do princípio de prazer. In: Edição Standard Brasileira das Obras Completas de Sigmund Freud: v. 18. Rio de Janeiro: Imago, 1996a. p. 13-75. (Trabalho original publicado em 1920)

. A psicologia dos processos oníricos. In: . Edição Standard Brasileira das Obras Completas de Sigmund Freud: v. 5. Rio de Janeiro: Imago, 1996b. p. 541-650. (Trabalho original publicado em 1900)

Psicologia de grupo e a análise do ego. In: . Edição Standard Brasileira das Obras Completas de Sigmund Freud: v. 18. Rio de Janeiro: Imago, 1996. p. 89-179. (Trabalho original publicado em 1921)

Três ensaios sobre a teoria da sexualidade. In: . Edição Standard Brasileira das Obras psicológicas completas de Sigmund Freud: v. 7. Rio de Janeiro: Imago, 1976. p.157-246. (Trabalho original publicado em 1905)

O eu e o Id. In: . Edição Standard Brasileira das Obras Psicológicas Completas de Sigmund Freud: v. 19. Rio de Janeiro: Imago, 1976. p. 13-86. (Trabalho original publicado em 1923)

FRITH, S. Towards an Aesthetic of Popular Music. In: LEPPERT R.; MCCLARY, S. (Eds) 
Music and Society: The Politics of Composition, Performance and Reception. Cambridge: Cambridge University Press. 1987.

FRITH, U. (Ed.). Autism and Asperger Syndrome. Cambridge: Cambridge University Press, 1991.

GALLESE, V. et al. Action recognition in the premotor cortex, Brain n. 119, p. 593-609, 1996.

GEROSA, M. et al. Analyzing children's speech: an acoustic study of consonants and consonant-vowel transition. Proceedings of the International Conference on Acoustics, Speech, and Signal Processing (ICASSP) p. 393-396. Toulose, França, 2006.

GIBBS, A. After Affect: Sympathy, Synchrony and Mimetic Communication. In: GREGG, M. SEIGWORTH, G. J. (Eds.). The Affect Theory Reader. Durham: Duke University Press, 2010. p. 186-205.

GOLD, C.; WIGRAM, T.; ELEFANT, C. Musicoterapia para el trastorno de espectro autista. La Biblioteca Cochrane Plus, Oxford, n. 2., p. 1-20, 2008.

GOUX, J.-P. La fabrique du continu. Seyssel: Champ Vallon, 1999.

GRATIER, M.Les rythmes de l'intersubjectivité. Spirale, v. 4, n. 44, p. 47-57, 2007.

.; TREVARTHEN, C. Musical Narrative and Motives for Culture in Mother-Infant Vocal Interaction. Journal of Consciousness Studies, v. 15, n. 10-11, p. 122-58, 2008.

GREEN, A. The Chains of Eros. Londres: H. Karnac, 2008.

HAAG, G. Clivages dans les premières organisations du moi: sensorialités, organisation perceptive et image du corps. Le Carnet PSY, n. 112, p. 40-42, 2006.

HACKING, I. Ontologia histórica. São Leopoldo: Unisinos, 2009.

HAGGARD, E. A.; ISAACS, K. S. Micro-momentary facial expressions as indicators of ego mechanisms in psychotherapy. In: GOTTSCHALK, L. A.; AUERBACH, A. H. (Eds.). Methods of Research in Psychotherapy. Nova Iorque: Appleton-Century-Crofts, 1966. p. 154-165.

HEADLAM, D. Learning to Hear Autistically. In: LERNER, N.; STRAUS, J. N. Sounding Off: Theorizing Disability in Music. Nova Iorque: Routledge, 2006. p. 109-120.

HEIMANN, M. et al. Imitation in autism: A preliminary research note. Behavioural Neurology, v. 5, p. 219-227, 1992.

HELMHOLTZ, L. F. On the sensations of tone as a physiological basis for the theory of music. Nova Iorque: Dover, 1954. 
HIKIJI, R. S. G. A música e o risco: etnografia da performance de crianças e jovens. São Paulo: Editora da Universidade de São Paulo, 2006.

HILL, E. L. Executive dysfunction in autism. Trends in Cognitive Science. v. 8, n. 1, p. 26-32, 2004.

HOBSON, R. P. The Cradle of Thought: Exploring the Origins of Thinking. Oxford: Oxford University Press, 2002.

.; LEE, A. Imitation and Identification in Autism. J. Child Psychol. Psychiat., Cambridge, v. 40, n. 4, p. 649-659, 1999.

HOLCK, U. Music Therapy for children with communication disorders. In: WIGRAM, T.; PEDERSEN, I. N.; BONDE, I. O. A comprehensive guide to music therapy. Londres: Jessica Kingsley, 2002. p. 183-187.

ITARD, J. M. G. De L'éducation d'un Homme Sauvage Ou Des Premiers Développemens Physiques Et Moraux Du Jeune Sauvage De L'aveyron. Paris: Goujon, 1801.

JAFFE, J. et al. Rhythms of Dialogue in Infancy: Monograph of the Society for Research in Child Development. Maiden, MA: Blackwell, 2001.

JAQUES-DALCROZE, E. La musique et nous: notes sur notre double vie. Genebra: PerretGentil, 1945.

JERUSAlinSKY, A. Para uma Clínica Psicanalítica das Psicoses. Estilos da clinica., v. 1, n. 1, p. 146-163, 1996.

JOURDAIN, R. Music, The Brain, and Ecstasy: How music captures our imagination. Nova Iorque: William Morrow and Company, 1997.

KANNER, L. Affective disturbances of affective contact. Nervous Child, v. 2, p. 217-250, 1943.

KAUFMANN, P. Dicionário enciclopédico de psicanálise: o legado de Freud e Lacan. Rio de Janeiro: Jorge Zahar, 1998.

KIVY, P. Introduction to a philosophy of music. Oxford: Clarendon, 2002.

KLEIN, M. A importância da formação de símbolos no desenvolvimento do ego. In:

Obras completas de Melanie Klein: Vol. I. Melanie Klein, amor, culpa e reparação e outros trabalhos (1921-1945). Rio de Janeiro: Imago Ed., 1996, p.249-264. (Trabalho original publicado em 1930)

KOELREUTTER, H. J. Introdução à estética relativista do impreciso e do paradoxal. Resumo de aulas. SP: Instituto de Estudos Avançados da Universidade de São Paulo, 1987/1988

KUPFER, M. C. M. O Sujeito na Psicanálise e na Educação: bases para a educação terapêuti- 
ca. Educação \& Realidade. v. 35, n. 1, p. 265-281, jan/abr 2010.

. (Coord.). Relatório científico final: leitura da constituição e da psicopatologia do laço social por meio de indicadores clínicos: uma abordagem multidisciplinar atravessada pela psicanálise. (Projeto Temático FAPESP, n. 2003/09687-7). São Paulo, 2008.

. Educação para o futuro. São Paulo: Escuta, 2000.

. et al. Valor preditivo de indicadores clínicos de risco para o desenvolvimento infantil: um estudo a partir da teoria psicanalítica. Rev. latinoam. psicopatol. fundam., São Paulo, v. 13, n. 1, Mar. 2010.

. et al. Roteiro para a Avaliação Psicanalítica de Crianças de três anos - AP3. In: LERNER, R., . (Orgs.). Psicanálise com crianças: Clínica e pesquisa. São Paulo: Escuta, 2008, p. $137-147$.

.; INAFUKU, C. K. ; FARIA, C. A. O tratamento institucional do Outro na psicose infantil. Arquivos Brasileiros de Psicologia, v. 59, p. 156-166, 2008.

LACAN, J. O Seminário Livro XVI: de um Outro ao outro. Rio de Janeiro: Jorge Zahar, 2008.

. O Seminário Livro X: a angústia. Rio de Janeiro: Jorge Zahar, 2005.

. O Saber do Psicanalista. Recife: Centro de Estudos Freudianos do Recife, 2000.

. O Seminário Livro XI: os quatro conceitos fundamentais da psicanálise. Rio de Janeiro: Jorge Zahar, 1998.

O Seminário Livro II: o eu na teoria de Freud e na técnica da psicanálise. Rio de Janeiro: Jorge Zahar, 1987.

O Seminário: Livro I: os escritos técnicos de Freud. Rio de Janeiro:

Jorge Zahar, 1986.

O Seminário Livro VII: a ética da psicanálise. Rio de Janeiro: Jorge Zahar, 1985.

LAI et al. Neural systems for speech and song in autism. Brain, v. 135, p. 961-975, 2012.

LAMPREIA, Carolina. Os enfoques cognitivista e desenvolvimentista no autismo: uma análise preliminar. Psicol. Reflex. Crit., Porto Alegre, v. 17, n. 1, 2004.

LANGDON, J. The Symbolic Efficacy of Rituals: From Ritual to Performance. Antropologia em primeira mão, n. 1, p. 5-40, 1995.

LAZNIK, M.-C. La voix comme premier objet de la pulsion orale. Psychanalyse et enfance, n. 28, p. 101-117, 1999. 
Do fracasso da instauração da imagem do corpo ao fracasso da instauração do circuito pulsional: Quando a alienação faz falta. In: aos psicanalistas. Salvador: Álgama, 1998. p. 31-48. . O que a clínica do autismo pode ensinar Rumo à palavra: Três crianças autistas em psicanálise. São Paulo: Escuta, 1997. et al. Interações sonoras entre bebês que se tornaram autistas e seus pais. Coloquio franco-brasileiro sobre a clínica com bebês, Paris, 2005.

LEBOYER, M. Autismo infantil: fatos e modelos. Campinas, SP: Papirus, 2007.

LECOURT, E. L'intervalle musical: entre l'autre et l'Autre. Insistance, v. 6, p. 119-132, 2011. Freud et l'univers sonore: le tic-tac du désir. Paris: L'Harmattan, 1992.

LEE, C. A. The architecture of aesthetic music therapy. Gilsum: Barcelona Publishers, 2003.

LEE, S.; POTAMIANOS, A.; NARAYANAN, S. Acoustics of children's speech: developmental changes of temporal and spectral parameters. J Acoust Soc Am. v. 105, n. 3, p. 1455$68,1999$.

LEINIG, C. A música e a ciência se encontram: um estudo integrado entre a música, a ciência e a musicoterapia. Curitiba: Juruá, 2008.

. Tratado de Musicoterapia. São Paulo: Sobral Editora Técnica Artesgráficas, 1977.

LÉVI-STRAUSS, C. Jean-Jacques Rousseau, fundador das ciências do homem. In: . Antropologia Estrutural Dois. Tempo Brasileiro: Rio de Janeiro, 1993. p. 41-51

. A eficácia simbólica. In: . Antropologia Estrutural. Rio de Janeiro: Tempo Brasileiro, 1975. p. 215-236.

Totemism. Londres: Merlin Press, 1964.

LIEBERMAN, F. Zen Buddhism And Its Relationship to Elements of Eastern And Western Arts. Disponível em: <http://artsites.ucsc.edu/faculty/lieberman/zen.html>. Acesso em 11 jan. 2016.

LIMA, T. M. T. Música e invocação: uma oficina terapêutica com crianças com transtornos de desenvolvimento. Dissertação (Mestrado em Psicologia Escolar e do Desenvolvimento Humano) - Instituto de Psicologia, Universidade de São Paulo, São Paulo, 2012.

et al. Música, Corpo e Movimento: proposta de uma oficina com crianças portadoras de transtornos de desenvolvimento. In: II seminário de Pesquisa do Programa de Pós-Graduação em Psicologia Escolar e do Desenvolvimento Humano, 2008, São Paulo. II Seminário de Pesquisa do Programa de Pós-Graduação em Psicologia Escolar e do Desenvolvimento Humano, 2008. São Paulo: IP/USP, 2008. 
LOCKE, J. An Essay Concerning Human Understanding. Disponível em: <http://www.earlymoderntexts.com/assets/pdfs/locke1690book2.pdf>. Acesso em 13 jan. 2016. (Trabalho original publicado em 1690)

LÓPEZ, A. L. L. A escuta psicanalítica de uma criança autista. Estudos de Psicanálise, Aracaju, n. 34, p. 13-20, dezembro, 2010.

LOSH, M.; CAPPS, L. Narrative Ability in High-Functioning Children with Autism or Asperger's Syndrome. Journal of Autism and Developmental Disorders, v. 33, n. 3, p. 239-251, 2003.

LUGAR DE VIDA. Apresentação. Disponível em: <http://lugardevida.com.br/>. Acesso em 22 set. 2015.

MALLOCH, S. N. Mothers and infants and communicative musicality. Musicae Scientiae, Jyvaskyla, Special Issue 1999-2000, p. 29-57, 1999.

MARSOLA, M.; BAÊ, T. Canto, Uma Expressão. São Paulo: Irmãos Vitale, 2000.

MARTÍNEZ, M. Juego Musical y Trastornos del Espectro Autista. In: Reunion Anual de la Sociedad Argentina para las Ciências Cognitivas de la Música, 8, 2009, Universidad Nacional de Villa María. La experiencia artística y la cognición musical. Córdoba: SACCoM, 2009.

MASSIE, D. M. The Baby Beebee Bird. Nova Iorque: HarperCollins, 1978.

MELTZOFF, A. N., MOORE M. K. Imitation of facial and manual gestures by human neonates. Science, v. 198, p. 75-78, 1977.

MENDOZA, M. Versão infantil do Teste "Ler a Mente nos Olhos"("Reading the Mind in the Eyes"Test): um estudo de validade. Dissertação (Mestrado em Psicologia Clinica). Instituto de Psicologia da Universidade de São Paulo. São Paulo, 2012.

MENEZES BASTOS, R. J. A Musicológica Kamayurá: Para uma antropologia da comunicação no Alto-Xingu. Brasília: Fundação Nacional do Índio,1978.

MERKER, B. Synchronous chorusing and human origins. In: WALLIN, N. L.; MERKER, B.; BROWN, S. (Eds.). The Origins of Music. Cambridge: MIT Press, 2000. p. 315-327.

MERRIAM, A. P. The Anthropology of Music. Evanston: Northwestern University Press, 1964.

. Definitions of "Comparative Musicology" and "Ethnomusicology": A HistoricalTheoretical Perspective. Ethnomusicology v. 21, n. 2, p. 189-204, 1977.

MEZAN, R. Psicanálise, judaísmo: ressonâncias. Campinas: Escuta, 1986.

MILLER, J.-A. Jacques Lacan et la voix. In: FONAGY, I. et al. La voix: Actes du colloque d'Ivry. Paris: La lysimaque, 1989. 
MILLS, J. A Critique of Relational Psychoanalysis. Disponível em: <http://www.processpsychology.com/new-articles2/Critique of Relational Psychoanalysis.pdf >. Acesso em 10 fev. 2016.

MIYAKE, K. et al. Epigenetics in Autism and Other Neurodevelopmental Diseases. In: AHMAD, S. I. (Ed.). Neurodegenerative Diseases. Advances in Experimental Medicine and Biology, v. 724. Nova Iorque: Springer, 2012. p 91-98.

MURATORI, F.; MAESTRO, S. Early signs of autism in the first year of life. In: ACQUARONE, S. (Ed.). Signs of autism in infants: recognition and treatment. London: Karnac, 2007a. p. 46- 62 .

Autism as a Downstream Effect of Primary Difficulties in Intersubjectivity Interacting with Abnormal Development of Brain Connectivity. International Journal for Dialogical Science, v. 2, n. 1, p. 93-118, 2007b.

NAGY, E.; MOLNAR, P. Homo imitans or homo provocans? Human imprinting model of neonatal imitation. Infant Behavior \& Development, v. 27, p. 54-63, 2004.

NETTL, B. The Study of Ethnomusicology: Twenty-Nine Issues and Concepts. Urbana e Chicago: University of Illinois Press, 1983.

Press, 1976.

Folk music in the United States: an introduction. Detroit : Wayne State University

NIETZSCHE, F. Genealogia da Moral. São Paulo: Brasiliense, 1987.

NORDOFF, P.; ROBBINS, C. Therapy in Music for Handicapped Children. Gilsum: Barcelona Publishers, 2004.

OCHS, E. et al. Autism and the social world: an anthropological perspective. Discourse Studies, v. 6, n. 2, p. 147-183, 2004.

OHTA, M. Cognitive disorders of infantile autism: A study employing the WISC, spatial relationship conceptualization, and gesture imitations. Journal of Autism and Developmental Disorders, v. 17, p. 45-62, 1987.

OVERY, K., MOLNAR-SZAKACS, I. Being Togheter in Time: Musical Experience and the Mirror Neuron System. Music Perception, n. 26, v. 5, p. 489-504, 2009.

OXMAN, J.; WEBSTER, C. D.; KONSTANTAREAS, M. M. Condon's multiple-response phenomenon in severely dysfunctional children: An attempt at replication. Journal of autism and childhood schizophrenia. v. 8, n. 4, p. 395-402, 1978.

PADILHA, M. C. P. A Musicoterapia no Tratamento de Crianças com Perturbação do Espectro do Autismo. Dissertação (Mestrado Integrado em Medicina) - Universidade da Beira Interior, Portugal, Covilhã, 2008. 
PANKSEPP, J. Affective Neuroscience: The Foundations of Human and Animal Emotions. Nova Iorque: Oxford University Press, 1998.

PAPOUŠEK, H. Musicality in infancy research: Biological and cultural origins of early musicality. In: DELIÈGE, I.; SLOBODA, J. (Eds.). Musical Beginnings: Origins and Development of Musical Competence. Nova Iorque: Oxford University Press, 1996. p. 37-55.

.; PAPOUŠEK, M. Vocal imitations in mother-infant dialogues. Infant Behavior and Development, 5, 176, 1982.

PIAGET, J. A formação do símbolo na criança. Rio de Janeiro: Zahar Editores, 1951. 304, 1923.

La pensée symbolique et la pensée de l'enfant, Archives de psychologie, v. 18, p. 273.; INHELDER, B. A psicologia da criança. Rio de Janeiro: Bertrand Brasil, 2003.

PINHEIRO, T. Prefácio: O que essas crianças têm? In: ROCHA, P. S. (Org.). Autismos. São Paulo: Escuta, 1997. p. 11-18.

PINTO, F. S. C. N. Grupo Mix: um campo de linguagem para a circulação da heterogeneidade. 2009, 115f. Dissertação (Mestrado em Psicologia Escolar e do Desenvolvimento Humano) - Instituto de Psicologia, Universidade de São Paulo, São Paulo, 2009.

PLATÃO. The Republic. New Haven: Yale University Press, 2006.

PONTALIS, J.-B. Bordas ou Confins?. In: ___ Entre o Sonho e a Dor. São Paulo: Idéias e Letras, 2005. p. 211-225.

PORGE, E. Voz do Eco. Campinas: Mercado de Letras, 2014.

PRATT, C. An Encyclopedia of Shamanism. Nova Iorque: The Rosen Publishing Group, 2007.

RABINOW, P.; DREYFUS, H. Michel Foucault. uma trajetória filosófica. Para além do estruturalismo e da hermenêutica. Rio de Janeiro: Forense Universitária, 1995.

REIK, T. The haunting melody: Psychoanalytic experiences in life and music. Nova Iorque: Farrar, Straus, and Young, 1953.

REINACH, T. A Música Grega. São Paulo, Perspectiva, 2011.

RENSHAW, J. 'A eficácia simbólica' revisitada: Cantos de cura ayoreo. Revista de Antropologia, São Paulo, v. 49, n. 1, p. 393-427, 2006.

RHODE, M. Echo or answer? The move towards ordinary speech in three children with autistic spectrum disorder. In: ALVAREZ, A.; REID, S. (Eds.). Autism and personality: Findings from the Tavistock Autism Workshop. Londres e Nova Iorque: Routledge, 1999. p. 79- 
92.

RICHTER, E.; SONG, B. Translating the concept of 'identity'. In: HUNG, E. Translation and Cultural Change: Studies in history, norms and image-projection. Amsterdã e Filadélfia: John Benjamins Publishing Company, 2005. p. 91-110.

RICOEUR, P. Tempo e narrativa. São Paulo: Martins Fontes, 2012.

. Oneself as another. Chicago: University of Chicago Press, 1992.

. Narrative Identity. Philosophy Today, v. 35, n. 1, p. 73-80, 1991.

RIMBAUD, A. Carta a Georges Izambard. Alea, v. 8, n.1, p. 154-163, 2006. (Trabalho original publicado em 1871)

RITVO E.R. et al. Concordance for the syndrome of autism in 40 pairs of afflicted twins. American Journal of Psychiatry, v. 142, p. 74-77, 1985.

RIZZOLATTI, G. et al. Premotor cortex and the recognition of motor actions. Cog. Brain Res., v. 3, p. 131-141, 1996.

ROCHA, P. S. (Org.). Autismos. São Paulo: Escuta, 1997.

ROSEMAN, M. Healing Sounds from the Malaysian Rainforest: Temiar Music and Medicine. Berkeley e Los Angeles: University of California Press, 1991.

RODULFO, R. Alguns passos na cura psicanalítica de crianças autistas: um informe clínico. Estilos clin., São Paulo, v. 4, n. 7, p. 10-17, 1999.

ROUSSEAU, J.-J. Ensaio sobre a origem das línguas. Campinas: UNICAMP, 2008. (Trabalho original publicado em 1781)

ROUDINESCO, E.; PLON, M. Dicionário de psicanálise. Rio de Janeiro: Jorge Zahar, 1998.

RUUD, E. Caminhos da musicoterapia. São Paulo: Summus, 1990.

SADIE, S. (Ed.). Dicionario Grove de música: edição concisa. Rio de Janeiro: Jorge Zahar, 1994.

SAFATLE, V. Destituição subjetiva e dissolução do eu na obra de John Cage. In: RIVERA, T.; . (Orgs.). Sobre Psicanálise e Arte. São Paulo: Escuta, 2006, p. 163-197.

SALAMON, E. et al. The effects of auditory perception and musical preference on anxiety in naive human subjects. Medical Science Monitor, Smithtown, v. 9, n. 9, p. 396-399, 2003.

SAM, S.-A.; CAMPBELL, P. S. Silent Temples, Songful Hearts: Traditional Music of Cambodia. Danbury: World Music Press, 1992. 
SAMPAIO, P. S.; LEME, M. I. S.; LERNER, R. Contributions from Gallese's Neurophysiology and Bruner's Psychology to the Understanding of Social Learning. Psicologia: Reflexão e Crítica, v. 24, n. 4, p. 773-780, 2011.

SANTOS, J. F. et al. Very early detection of Autism Spectrum Disorders based on acoustic analysis of pre-verbal vocalizations of 18-month old toddlers. International Conference on Acoustics, Speech and Signal Processing, p. 7567-7571, 2013.

SCHEFLEN, A. A psychotherapy of schizophrenia: A study of direct analysis. Springfield: Thomas, 1960.

. Communication and regulation in psychotherapy. Psychiatry, v. 28, p. 126-136, 1963.

SCHUTZ, A. Making music together: a study in social relationship. In: Collected Papers II: Studies in Social Theory. Haia: Martinus Nijhoff, 1976. p. 159-178.

SCHUMACHER, K.; CALVET-KRUPPA, C. The AQR - an analysis system to evaluate the quality of relationship during music therapy. Nordic Journal of Music Therapy, v. 8, n. 2, 1999.

SCLIAR, M. Saturno nos trópicos: a melancolia européia chega ao Brasil. São Paulo: Companhia das Letras, 2003.

SEEGER, A. Por que canta Anthony Seeger?. Rev. Antropol., São Paulo, v. 50, n. 1, p. 389418, 2007.

Why Suyá sing?. Cambridge: Cambridge University Press, 1987.

SHAPIRO, T. et al. The speech of a schizophrenic child from two to six. The American Journal of Psychiatry, v. 128, n. 11, p. 1408-1414, 1972.

SHARDA, M. et al. Sounds of melody--pitch patterns of speech in autism. Neurosci. Lett., v. 478, p. 42-45. 2010.

SHEFF, D. All We Are Saying: The Last Major Interview with John Lennon and Yoko Ono. Nova Iorque: St. Martin's Press, 2000.

SHORT, A. E. Isoprinciple: the group approach. Australian Journal of Music Therapy, Malvern, v. 3, p. 57-62, 1992.

SILVA JÚNIOR, J. D. A utilização da música com objetivos terapêuticos: interfaces com a Bioética. Dissertação (Mestrado em Música) - Escola de Música e Artes Cênicas, Universidade Federal de Goiás, Goiás, 2008.

SMITH, B. G. Lower Extremity Disorders in Children and Adolescents. Pediatrics in Review, v. 30, p. 287-294, 2000.

SMITH, M. P. C. Cognição Musical X Identidade Sonoro-Musical. Disponível em: 
<http://biblioteca-da-musicoterapia.com/biblioteca/arquivos/artigo//Maristela Cognicao $\mathrm{Mu}-$ sical e Identidade Sonoro-Musical.pdf>. Acesso em 21 set. 2014.

SPITZ, B. The Beatles: The Biography. Nova Iorque: Little, Brown and Company, 2005.

STERN, D. N. The relevance of empirical infant research to psychoanalytic theory and pratcice. In: SANDLER, J.; SANDLER, A.-M.; DAVIES, R. Clinical and observational psychoanalytic research: roots of a controversy. Londres: H. Kamac, 2000, p. 73-90

. Vitality contours: The temporal contour of feelings as a basic unit for constructing the infant's social experience. In: ROCHAT, P. (Ed.), Early Social Cognition: Understanding Others in the First Months of Life. Mahwah: Erlbaum, 1999. p. 67-90

L'enveloppe prénarrative: Vers une unité fondamentale d'expérience permettant d'explorer la réalité psychique du bébé. Revue internationale de Psychopathologie, v. 6, p. 1363, 1992.

The interpersonal world of the infant: a view from psychoanalysis and developmental psychology. Nova Iorque: Basic Books, 1985.

et al. Affect Attunement: The sharing of feeling state between mother and infant by means of intermodal fluency. In: FIELD, T.; FOX, N. (Eds.). Social Perception in Infants. Norwood: Ablex, 1985. p. 249-268.

STRAVINSKY, I. Chronicle of my life. Londres: Victor Gollancz, 1936

STONE, W. L. et al. Play and imitation skills in the diagnosis of autism in young children. Pediatrics, v. 64, p. 1688-1705, 1990.

TAGER-FLUSBERG, H. Once upon a ribbit: Stories narrated by autistic children. British Journal of Developmental Pyschology, v. 13, p. 45-59, 1995.

.; SULLIVAN, K. Predicting and explaining behavior: A comparison of autistic, mentally retarded and normal children. Journal of Child Psychology and Psychiatry, v. 35, p. 10591075, 1994.

TATIT, L. O cancionista: composição de canções no Brasil. São Paulo: EdUSP, 1995

TAUSSIG, M. T. Mimesis and Alterity: A Particular History of the Senses. Nova Iorque: Routledge, 1993.

THAUT, M. H. Rhythm, Music and the Brain: Scientific Foundations and Clinical Applications. Routledge: Nova Iorque, 2005.

TIUSSI, C. C. Grupo em educação terapêutica com crianças: alcance e limites de um dispositivo. Dissertação (Mestrado em Psicologia Escolar e do Desenvolvimento Humano) - Instituto de Psicologia, Universidade de São Paulo, São Paulo, 2012. 
TODRES, I. D. Música é remédio para o coração. Jornal de Pediatria, Rio de Janeiro, v. 82, n. 3, p. 166-168, 2006.

TRAPPE, H. J. The effects of music on the cardiovascular system and cardiovascular health. British Medical Journal, Londres, v. 96, n. 23, p. 1868-1871, 2010.

TREVARTHEN, C. Autism, sympathy of motives and music therapy. Enfance, v. 54, p. 8699, 2002.

Autism as a neurodevelopmental disorder affecting communication and learning in early childhood: Prenatal origins, postnatal course and effective educational support. Prostoglandins, Leucotrines and Essential Fatty Acids, v. 63, n. 1/2, p. 41-46, 2000.

Musicality and the Intrinsic Motive Pulse: Evidence from human psychobiology and infant communication. Musicae Scientiae: Special Issue - Rhythms, Musical Narrative, and the Origins of Human Communication, p. 157-213, 1999. 1997.

Music and Infant Interaction, Nordisk Tidsskrift for Musikkterapi, v. 6, n. 1, p. 61-65,

The foundation of intersubjectivity: Development of interpersonal and cooperative understanding in infants,. In: OLSON, D. (Ed.). The Social Foundation of Language and Thought. Nova Iorque: Norton, 1980. p. 316-342.

Communication and cooperation in early infancy: A description of primary intersubjectivity. In: BULLOWA, M.M. (Ed.). Before Speech: The Beginning of Interpersonal Communication. Nova Iorque, Cambridge University Press, 1979.

. Conversations with a two-month-old. New Scientist, v. 2, p. 230-235, 1974.

.; DANIEL, S. Disorganized rhythm and synchrony: Early signs of autism and Rett syndrome. Brain \& Development, v. 27, p. S25-S34, 2005.

.; HUBLEY, P. Secondary intersubjectivity: confidence, confiders and acts of meaning in the first year. In: LOCK, A. (Ed.). Action, Gesture and Symbol. Nova Iorque: Academic Press, 1978.

.; MALLOCH, S. N. Musicality: Communicating the vitality and interests of life. In:

.; MALLOCH, S. N. (Eds.) Communicative musicality: Exploring the basis of human companionship. Nova Iorque: Oxford University Press, 2009. p. 1-11

.; MALLOCH, S. N. The dance of the wellbeing: definig the musical therapeutic effect. Nordic Journal of Music Therapy, Bergen, v. 9, n. 2, p. 3-17, 2000.

et al. Children with Autism: Diagnosis and Interventions to Meet Their Needs. London: Jessica Kingsley, 1998.

TURNER, V. Dewey, Dilthey, and Drama: An Essay in the An thropology of Experience. In: 
; BRUNER, E. The Anthropology of Experience. Urbana e Chicago: University of Illinois, 1986. p. 3-32.

. On the edge of the bush. Tucson: University of Arizona Press, 1985.

TUSTIN, F. Autismo e psicose infantil. Rio de Janeiro: Imago, 1975.

TYSON, F. Psychiatric music therapy: Origins and development. Nova Iorque: Creative Arts Rehabilitation Center, 1981.

UM ENCONTRO com Lacan. Direção: Gerard Miller. Paris, 2011. (53 min).

URWIN, C. Emotional life of autistic spectrum children: What do we want from child psychotherapy treatment. Psychoanalytic Psychotherapy, v. 25, n. 3, p. 245-261

A psychoanalytic approach to language delay: When 'autistic' isn't necessarily autism. Journal of Child Psychotherapy, v. 28, n. 1, p. 73-93, 2002.

VAKIRTZI, E. The Archaeology of Autism and the Emergence of the Autistic Subject. Tese (Doutorado em Filosofia da Educação) - University of Exeter, Exeter, 2010.

VASSE, D. O umbigo e a voz: Psicanálise de duas crianças. São Paulo: Loyola, 1977.

VILENSKY, J. A.; DAMASIO, A. R.; MAURER, R. G. Gait disturbances in patients with autistic behavior: a preliminary study. Arch. Neurol., v. 38, p. 646-649, 1981.

VIVÈS, J-M. Pour introduire la question du point sourd. In: Psychologie Clinique: La voix dans la rencontre clinique. Paris: L'Harmattan, 2005.

WATERMAN, C. Juju: a social history. Chicago: University of Chicago Press, 1991.

WEBER, M. The rational and social foundations of music. Carbondale: Southern Illinois University Press, 1958.

WIGRAM, T. Improvisation: methods and techniques for music therapy clinicians, educators, and students. Londres e Filadélfia: Jessica Kingsley Publishers, 2004.

WILLIAMS, R. The long revolution. Harmondsworth: Penguin, 1965.

WILLOUR, J. Beginning with delight, leading to wisdom: Dalcroze. Music Educators Journal, n. 56, v. 1, p. 72-75, 1969.

WING, L. El autismo en niños y adultos: una guía para la familia. Barcelona: Paidós, 1996. Asperger's syndrome: a clinical account. Psychol Med, v. 11, n. 1, p. 115-129, 1981. .; GOULD, J. Severe Impairments of Social Interaction and Associated Abnormalities 
in Children: Epidemiology and Classification, Journal of Autism and Developmental Disorders, v. 9, p. 11-29, 1979.

WINNICOTT, D. W. Autismo. In: . Pensando sobre crianças. Porto Alegre: Artes Médicas, 1996. p. 179-192. O brincar e a realidade. Rio de Janeiro: Imago, 1975.

WHIPPLE J. Music in intervention for children and adolescents with autism: A meta-analysis. Journal of Music Therapy, v. 41, n. 2, 2004.

WITTGENSTEIN, L. Philosophical investigations. Oxford: Basil Blackwell, 1953.

WOSCH, T.; WIGRAM, T. Microanalysis in Music Therapy: Introduction and Theoretical Basis. In: . (Eds.). Microanalysis in Music Therapy: Methods, Techniques and Applications for Clinicians, Researchers, Educators and Students. London and Philadephia: Jessica Kingsley, 2007. p. 13-26.

ZANETTI, S.; BERG, R. A oficina de música no Lugar de Vida. I Semana de Arte de Psicologia da USP. Lugar de Vida, IP-USP, 2005.

ZENONI, A. Pratique institutionelle et orientation analytique. Les Feuillets du Courtil, Bruxelas, n. 20, v. 1, p. 17-30, 2002.

. “Traitement” de l'autre. Préliminaire, Antenne 110, Bruxelas, n. 3, p. 101-113, 1991.

ZIZEK, S. The Big Other Doesn't Exist. Journal of European Psychoanalysis, 1997 Como ler Lacan. Rio de Janeiro: Zahar, 2010.

ZUCKERKANDL, V. Man the musician. Princenton: Princenton University Press, 1976. 
ANEXO A - TERMO DE CONSENTIMENTO LIVRE E ESCLARECIDO

\section{Universidade de São Paulo Instituto de Psicologia}

Seu (Sua) filho(a) está sendo convidado a participar da pesquisa "A musicalidade comunicativa das canções pessoais: um estudo sobre a identidade sonora de crianças diagnosticadas com transtornos do espectro do autismo", realizada pelo pesquisador responsável Daniel Camparo Avila e esclarecida abaixo. No caso de você concordar com a sua participação, favor assinar ao final do documento, rubricando todas as páginas.

OBJETIVO: O objetivo desta pesquisa é estudar os efeitos clínicos da música e das canções pessoais no tratamento de crianças diagnosticadas com transtornos do espectro do autismo.

JUSTIFICATIVA: Existem indícios de que a música é usada com fins terapêuticos desde o tempo dos Egípcios antigos. Hoje, acompanhamos a multiplicação das suas aplicações práticas no campo da saúde, abrangendo diagnóstico, prevenção, cura ou reabilitação em situações clínicas variadas. Essas práticas exigem estudos aprofundados para que sejam compreendidas, melhoradas, e mesmo aceitas pela comunidade acadêmica e a sociedade em geral. Este estudo está voltado a um aspecto ainda pouco estudo nessa linha: os efeitos terapêuticos das canções no tratamento aos transtornos do espectro do autismo.

PROCEDIMENTOS DO ESTUDO: O pesquisador responsável coordenará um grupo terapêutico no qual serão empregados os seguintes procedimentos: a improvisação musical, o jogo musical e as canções pessoais. Os sujeitos terão à sua disposição instrumentos musicais que serão usados nas diversas atividades. As sessões serão registradas por meio de uma câmera de vídeo e esse material será analisado como parte da pesquisa. O pesquisador poderá solicitar a aplicação da Avaliação Psicanalítica aos 3 anos, entrevista com a criança e o responsável, para coletar dados sobre o sujeito e a intervenção. A confidencialidade e a privacidade, a proteção da imagem e a não-estigmatização estarão assegurados com a não-exibição da imagem e o sigilo absoluto da identidade do sujeito. Os resultados obtidos durante este estudo serão mantidos em sigilo, podendo ser divulgados em publicações científicas, sem que quaisquer dados pessoais sejam mencionados.

RISCOS E DESCONFORTOS: Decorrem fundamentalmente da exposição a uma situação de grupo, o que pode gerar situações de estresse ou ansiedade. Nesses casos, a criança poderá sair da sala de atendimento a qualquer momento, acompanhado por um adulto. Riscos físicos decorrentes da movimentação dos participantes no interior da sala de atendimento serão minimizados pela remoção de quaisquer objetos que possam interferir nessa circulação, bem como aqueles objetos que possam produzir qualquer tipo de acidente ou desconforto. O risco de possível identificação do sujeito de pesquisa será reduzido com o compromisso pelo sigilo absoluto da identidade do sujeito. 
BENEFÍCIOS: Espera-se que os sujeitos, quando submetidos a um tratamento que aplique a música com finalidades terapêuticas, se beneficiem individualmente com o desenvolvimento das funções básicas de socialização, comunicação e comportamento. Indiretamente, a pesquisa pode proporcionar um maior conhecimento a respeito do uso clínico da música em geral, e das canções em particular, produzindo um efeito de maior escala na sociedade, pela melhora dos tratamentos e da formação profissional, e na comunidade acadêmica, pelo aumento das pesquisas e debates sobre o tema.

CUSTO/REEMBOLSO PARA O PARTICIPANTE: Não haverá nenhum gasto com sua participação. As avaliações e a participação na pesquisa serão totalmente gratuitas, não havendo nenhuma cobrança pelo que será realizado. Você também não receberá nenhum pagamento pela participação.

$\mathrm{Eu}$ RG abai-

xo assinado(a), concordo de livre e espontânea vontade que meu (minha)

filho(a) nascido(a) em partici-

pe do estudo "A musicalidade comunicativa das canções pessoais: um estudo sobre a identidade sonora de crianças diagnosticadas com transtornos do espectro do autismo", da presente data até 30/11/2013. Informo que obtive todas informações necessárias e me foi dada a oportunidade de ler e esclarecer as minhas dúvidas. Sei que a qualquer momento poderei solicitar novas informações junto ao pesquisador responsável Daniel Camparo Avila, telefone: (11) 3063-2360, ou ainda com o Comitê de Ética em Pesquisa com Seres Humanos do Instituto de Psicologia da Universidade de São Paulo, endereço Av. Professor Mello Moraes, 1721 - Bloco G, $2^{\circ}$ andar, sala 27 CEP 05508-030 - Cidade Universitária - São Paulo/SP, telefone: (11) 3091-4182. Tenho ciência que posso modificar a decisão do menor sob minha responsabilidade participar do estudo, se assim o desejar, e que tal recusa não trará nenhum prejuízo em sua relação com o pesquisador ou com a instituição. Declaro que este termo de consentimento livre e esclarecido foi elaborado em duas vias, uma em minha posse e a outra com o pesquisador responsável.

Assinatura do(a) responsável pelo menor

Data 1
Assinatura do pesquisador responsável

Data 


\section{ANEXO B - TABELA DE CANÇÕES}

\begin{tabular}{|c|c|c|c|c|c|c|c|}
\hline Nome & Tonalidade $^{1}$ & Andamento $^{2}$ (bpm) & Compasso & Jogo musical & Tradicional & Contemporânea & Pessoal \\
\hline A oficina de música já vai começar & $\mathrm{G}$ & andante (100) & $4 / 4$ & Alternância de instrumentos & & & \\
\hline Atirei o pau no gato & $\mathrm{D}$ & allegretto (120) & $2 / 4$ & Coda & $\mathrm{X}$ & & \\
\hline Marcha, soldado & $\mathrm{C}$ & moderato (110) & $2 / 4$ & Roda & $\mathrm{X}$ & & \\
\hline Banho é bom (Rá-tim-Bum) & $\mathrm{C}$ & allegro (150) & $4 / 4$ & Tocar as partes do corpo/Coda & & $\mathrm{X}$ & \\
\hline Cocoricó (abertura) & $\mathrm{A}$ & vivace $(165)$ & $4 / 4$ & Alternância de intensidades & & $\mathrm{X}$ & \\
\hline Lá vem o pato & $\mathrm{C}$ & andante (110) & $4 / 4$ e $3 / 4$ & Coda & $\mathrm{X}$ & & \\
\hline O rato ladrão & $\mathrm{C}$ & andante (110) & $4 / 4$ e $3 / 4$ & Coda & & & $\mathrm{X}$ \\
\hline O gato folgado & $\mathrm{C}$ & andante (110) & $4 / 4$ e $3 / 4$ & Coda & & & $\mathrm{X}$ \\
\hline A dona aranha & $\mathrm{C}$ & andantino (105) & $2 / 4$ & Coreografia & $\mathrm{X}$ & & \\
\hline Os indiozinhos & $\mathrm{E}$ & andante (85) & $4 / 4$ & Coreografia/Coda & $\mathrm{X}$ & & \\
\hline Peixonauta & $\mathrm{D}$ & moderato (105) & $4 / 4$ & Alternância de intensidades & & $\mathrm{X}$ & $\mathrm{X}$ \\
\hline Thomas e seus amigos & $\mathrm{C}$ & andante $(90)$ & $4 / 4$ & Coda & & $\mathrm{X}$ & \\
\hline Pula a fogueira & $\mathrm{F}$ & allegro (130) & $4 / 4$ & - & $\mathrm{X}$ & & \\
\hline Cai, cai balão & $\mathrm{C}$ & allegretto $(120)$ & $4 / 4$ & - & $\mathrm{X}$ & & \\
\hline Capelinha de melão & A & andantino (108) & $4 / 4$ & - & $\mathrm{X}$ & & \\
\hline Ciranda, cirandinha & $\mathrm{D}$ & andante (87) & $4 / 4$ & Roda & $\mathrm{X}$ & & \\
\hline Lavar as Mãos & A & andante (92) & $4 / 4$ & - & & $\mathrm{X}$ & \\
\hline Era uma bruxa (parlenda) & - & - & - & Coreografia & $\mathrm{X}$ & & \\
\hline A canoa virou & A & moderato $(100)$ & $4 / 4$ & Coreografia & $\mathrm{X}$ & & \\
\hline Caranguejo não é peixe & A & andantino (95) & $2 / 4$ & Roda & $\mathrm{X}$ & & \\
\hline Se essa rua fosse minha & $\mathrm{E}$ & adagietto (73) & $4 / 4$ & Roda & $\mathrm{X}$ & & \\
\hline Um, dois, feijão com arroz & - & andantino $(95)$ & $2 / 4$ & Coreografia & $\mathrm{X}$ & & \\
\hline Peixe vivo & $\mathrm{C}$ & andante (83) & $4 / 4$ & - & $\mathrm{X}$ & & \\
\hline A oficina de música já vai terminar & $\mathrm{G}$ & andante $(100)$ & $4 / 4$ & Alternância de instrumentos & & & \\
\hline
\end{tabular}

\footnotetext{
Tonalidade usada na apresentação das canções.
}

Medida ideal estipulada pelo pesquisador com o auxílio de metrônomo, não corresponde àquela das atividades da oficina. 


\section{ANEXO C - GLOSSÁRIO DE TERMOS MUSICAIS}

(adaptado de SADIE, 1994)

Accelerando (accel.): Indicação de expressão musical, sinalizando um aumento gradual da velocidade de um trecho.

Allegro: Indicação de andamento, denotando o sentido de animado ou veloz (120-168 bpm).

Altura: 1. Atributo acústico que indica a percepção subjetiva da frequência fundamental de um som (pitch). 2. Propriedade perceptiva dos sons que permite diferenciá-los entre agudos e graves.

\section{Amplitude: Cf. intensidade.}

Andamento: Velocidade de uma peça ou trecho musical.

Andante: Indicação de andamento, denotando o sentido de um caminhar moderado (76-108 bpm).

Célula: Menor parte de um motivo ou frase musical.

Colcheia: Nota musical com metade da duração de uma semínima.

Coda: Passagem que conduz uma peça ou movimento ao seu final.

Cluster(pl. clusters): Grupo de notas consecutivas tocadas simultaneamente.

Crescendo (cresc. ou <): Indicação de um aumento gradual da intensidade de um trecho musical.

Diminuendo (dim. ou >; pl. diminuendi): Indicação de uma redução gradual da intensidade de um trecho musical.

Dueto: Execução de um trecho musical por duas vozes.

Fermata $(\curvearrowright):$ Prolongamento de uma nota, acorde ou pausa além da sua indicação de duração.

Figura: Pequenas ideias musicais com uma identidade particular de ritmo e/ou contorno melódico, com um grau mais elevado de complexidade que a célula.

Fortissimo (ff): Indicação de uma nota ou trecho musical que devem ser tocados com intensidade muito alta, equivalente ao volume da voz falando alto.

Frase: Unidade musical de tamanho variado, maior que um motivo.

Glissando: (pl. glissandi): Passagem contínua de uma nota a outra, incluindo as alturas inter- 
mediárias.

Intensidade: 1. Atributo acústico que indica a percepção subjetiva da amplitude de uma onda sonora. 2. Propriedade perceptiva dos sons que permite diferenciá-los entre altos e baixos.

Leitmotif: Frase musical recorrente em uma peça, representando uma pessoa, lugar ou ideia particular.

Ostinato: repetição indeterminada de uma unidade musical.

Motivo: 1. Ideia musical curta, seja ela melódica, harmônica ou rítmica, ou as três ao mesmo tempo. 2. Menor subdivisão com identidade própria de um tema ou frase.

Pianissimo (pp): Indicação de uma nota ou trecho musical que devem ser tocados com intensidade muito baixa, próximo ao volume da voz sussurrando.

Pitch: Cf. altura.

Ritardando (rit.): Indicação de expressão musical, sinalizando uma redução gradual da velocidade de um trecho.

Semibreve: Nota musical com duração de quatro semínimas.

Semicolcheia: Nota musical com metade da duração de uma colcheia.

Semínima: 1. Unidade de tempo das fórmulas de compasso usadas nas transcrições desta investigação. 2. Nota musical com valor de duração igual a um pulso.

Standard: Tema popular de jazz, frequentemente utilizado para organizar uma improvisação musical.

Solo: Execução de um trecho musical por apenas uma voz do conjunto.

Tema: 1. Material musical em que uma obra, ou parte dela, está baseado, geralmente uma melodia completa. 2. Unidade que se distingue do motivo tanto por sua maior extensão quanto por sua completude, que permite inclusive identificar uma obra.

Timbre: 1. Atributo acústico que indica a percepção subjetiva da forma e envelope de uma onda sonora. 2. Propriedade perceptiva dos sons que permite diferenciá-los em função dos instrumentos que os produzem.

Tutti: Execução de um trecho musical por todas as vozes do conjunto. 


\section{ANEXO D - FAIXAS DO CD}

1) Abertura e fechamento (Fig. 2)

2) Célula rítmica (Fig. 5)

3) Banho é bom (Fig. 6)

4) Atirei o pau no gato (Fig. 7)

5) Thomas e seus amigos (Fig. 8)

6) Thomas e seus amigos (Fig. 10)

7) Música assustadora (Fig. 12)

8) "Vai pegar o seu instrumento e vai tocar" (Fig. 13)

9) William - Cocoricó - flauta alta e aguda (Fig. 14)

10) Improvisação sobre Capelinha de Melão (Fig. 16)

11) Abertura (Fig. 22)

12) Mathias - "31 de junho" (Fig. 28) 